\title{
STYGOBIONT AMPHIPOD CRUSTACEANS OF THE HADZIOID GROUP FROM HAITI
}

\author{
by \\ JAN H. STOCK \\ Institute of Taxonomic Zoology, University of Amsterdam, \\ P.O. Box 20125, 1000 HC Amsterdam, The Netherlands
}

\begin{abstract}
The stygobiont gammarids of Haiti are more diversified than anywhere else in the world: not less than 13 species (all new) in 7 genera ( 5 new) and 4 subgenera (all new) are described of a somewhat loosely delimited group called the hadzioids/weckelioids.

Practically all species have limited ranges within Haiti, whose stream systems apparently have acquired a great deal of isolation.

The morphology of these amphipods makes even more indefinable the various supra-generic units proposed in the last 10 years for the "Gammaridae s.l."

\section{RÉSUMÉ}

Les Gammarides stygobiontes sont plus diversifiés à Haïti que n'importe où ailleurs: non moins de 13 espèces (toutes nouvelles) sont décrites; elles sont placées dans 7 genres (dont 5 nouveaux) et 4 sous-genres (tous nouveaux), le tout faisant partie d'un groupe assez imparfaitement délimité, désigné sous le nom de "hadzioides/weckelioides".

Pratiquement toutes les espèces ont des aires de distribution limitées à Haïti, île dont les bassins hydrographiques ont apparemment acquis un important degré d'isolement.

La morphologie de ces Amphipodes rend encore plus difficile la délimitation et définition des unités supragénériques diverses proposées ces 10 derniers années dans le cadre des "Gammaridae s.l."
\end{abstract}

\section{CONTENTS}

Introduction

Acknowledgements.

Key to the Haitian genera of hadzioids/weckelioids, based on characters visible without dissection ......

Key to the Haitian genera of hadzioids/weckelioids, mainly based on the mouthparts ................. 336

Zoogeographic remarks........................... 336

Taxonomic part 337

- Report 46 is published in the same issue of this journal.
Crangoweckelia n. gen................................. 337

Key to the species of Crangoweckelia $\left(\sigma^{\circ}, \$\right)$........... 337

Crangoweckelia mixta n. sp............................. 338

Crangoweckelia spinicauda $\mathrm{n}$. sp. ...................... 345

Pintaweckelia n. gen. ............................... 350

Pintaweckelia grandis n. sp......................... 350

Genus Metaniphargus Stephensen, 1933 ............. 357

Diagnosis of Metaniphargus s.1. .................... 357

Diagnoses of the West Indian subgenera ........... 357

Metaniphargus s. str. .............................. 357

Guadzia n. subgen................................ 357

Hispadzia n. subgen............................... 357

Haidzia n. subgen. .............................. 358

Jamadzia n. subgen. ............................. 358

Caribdzia n. subgen. ............................. 358

Croidzia n. subgen................................ 358

Key to the subgenera of Metaniphargus in the West Indies .................................... 358

Cladistics...................................... 358

Key to the Haitian species of Metaniphargus s.l. ....... 359

Metaniphargus (Caribdzia) haitianus n. sp............... 360

Metaniphargus (Hispadzia) longipalpus n. sp............ 365

Metaniphargus (Hispadzia) chaetodactylus n. sp.......... 370

Metaniphargus (Hispadzia?) pedunculatus n. sp.......... 375

Metaniphargus (Haidzia) plumicauda n. sp.............. 380

Metaniphargus (Guadzia) crenatus n. sp................. 386

Genus Bahadzia Holsinger, 1985 .................... 391

Bahadzia latipalpus n. sp. .......................... 391

Zombiweckelia n. gen. ............................... 400

Zombiweckelia parvipalpus n. sp....................... 400

Radaweckelia n. gen. ................................ 408

Radaweckelia brevicauda n. sp. ....................... 409

Apoweckelia n. gen. ................................. 417

Apoweckelia serrata n. sp. ............................ 418

Unidentifyable hadzioids/weckelioids.............. 425

References .................................... 426

\section{INTRODUCTION}

No hypogean Amphipoda were known up to now from Haiti, or from the island of 


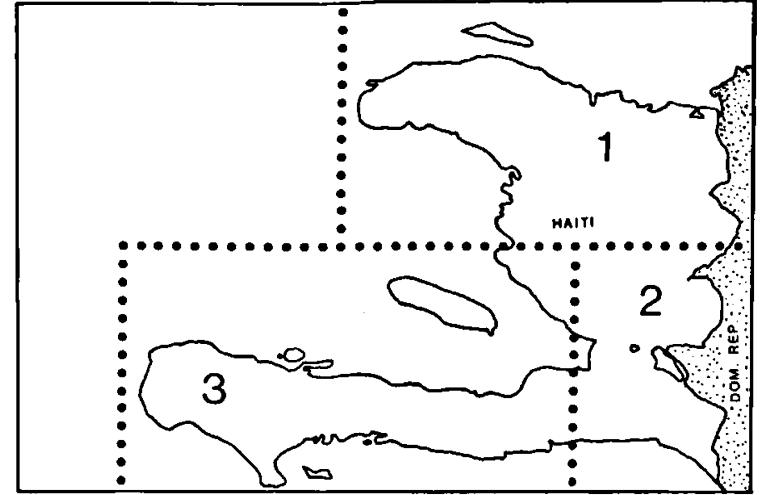

Fig. 1. Sketch map of Haiti, showing the subdivision into three hydrographic maps (figs. 2, 3, 4).
Hispaniola of which Haiti forms the western half. During two fieldwork periods (1978 and 1979), different teams of our University sampled 244 groundwater stations in Haiti. These stations are indicated on three hydrographic maps (figs. 2-4). The subdivision of Haiti into three maps is shown in fig. 1.

Not less than 51 stations $(21 \%)$ contained blind Amphipoda of the hadzioid/weckelioid grouping of the family Gammaridae s.l. The taxonomic diversity appeared to be unexpectedly great: 13 species (all new) in 7 genera (5 new). Moreover, members of not less than 4 subgenera (all new) of the genus Metaniphargus

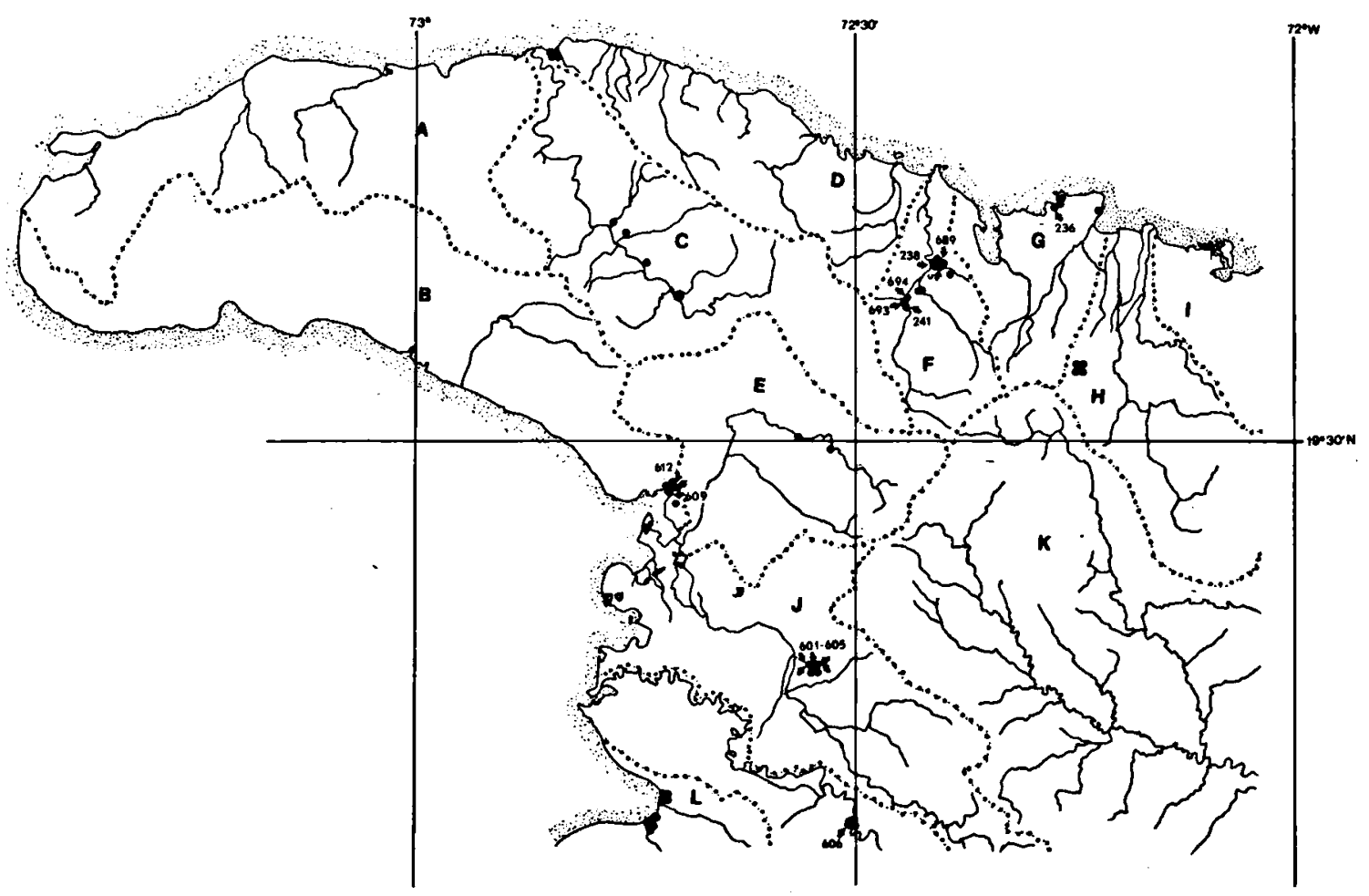

Fig. 2. Distribution of all stations (dots) in area 1 (see fig. 1) of Haiti. Stations with hadzioid/weckelioid Amphipoda are marked by arrows and station number (series 197-244 taken in 1978, series 500-694 taken in 1979, record U is based on a sample in the U.S. National Museum). Nearby stations are not always shown individually. The following hydrographic basins and zones can be distinguished in area 1 (source: map "Données hydrologiques et utilisation des eaux", $1: 250,000$; in: "Haiti - Mission d'assistance technique intégrée", published by the Organisation des Etats Américains, Washington, 1972):

A, Môle St. Nicolas/Moustique zone; B, Bombardopolis/Gonaïves zone; C, Bassin des Trois Rivières; D, Port-de-Paix/Port Margot zone; E, Bassin de la Quinte; F, Bassin du Limbé; G, Cap-Haïtien zone; H, Bassin de la Grande Rivière du Nord; I, Limonade/Ouanaminthe zone; J, Bassin de l'Estère; K, Bassin de l'Artibonite; L, St. Marc/Duvalierville zone. 


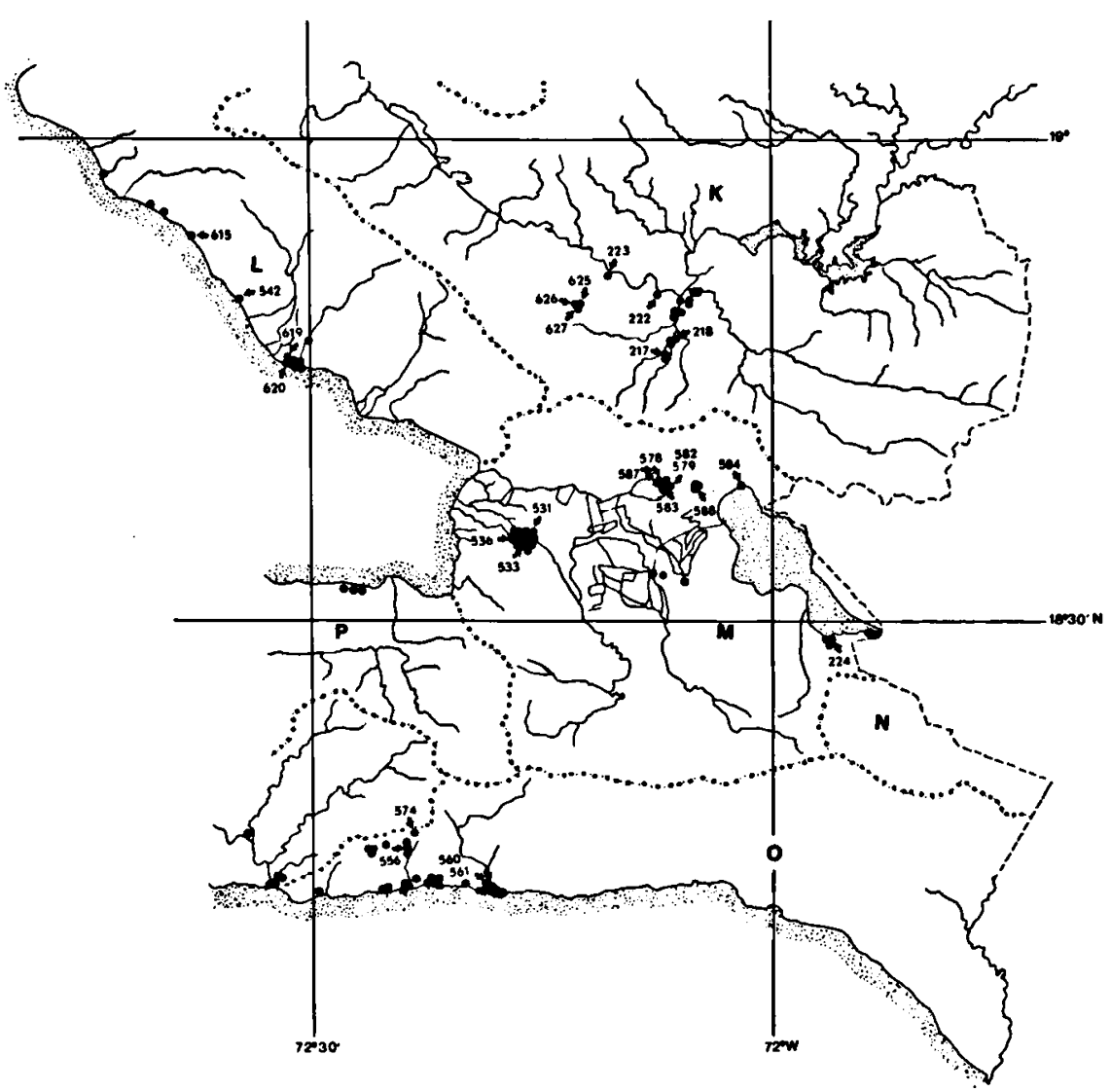

Fig. 3. Distribution of all stations (dots) in area 2 (see fig. 1) of Haiti. Stations with hadzioid/weckelioid Amphipoda are marked by arrows and station number. Nearby localities are not always shown individually. The following hydrographic basins and zones can be distinguished in area 2 (source see fig. 2):

K, Bassin de l'Artibonite; L, St. Marc/Duvalierville zone; M, Cul-de-Sac zone; N, Fond-Verrettes zone; O, CayesJacmel/Anse-à-Pitre zone; P, Léogane/Carrefour zone.

were found. This makes Haiti outright the country with the world's richest hadzioid fauna. The bogidiellids of Haiti (2 species only) have been treated elsewhere (Stock, 1985); members of the genera Hyalella (family Hyalellidae) and Quadrivisio (fam. Gammaridae s.l.), present in a number of samples, have not yet been subjected to a detailed study.

The most remarkable result of the present study resides in the morphology of the appendages of various taxa. For instance, the genus Bahadzia has a 2-segmented exopodite in the third uropod, and belongs therefore technically to the "hadzioids" (sensu Barnard \& Barnard,
1983); its remaining morphology, however, shows a close relationship with a number of taxa from continental Central and North America, which are considered "weckelioids". In my opinion, this shows that hadzioids and weckelioids are inseparable.

An even more surprising case yield the genera Crangoweckelia and Pintaweckelia which are in most characters typical "hadzioids", but which are "weckelioids" in their third uropod, and "crangonyctids" in their first gnathopod. In this respect, they are reminiscent of a New Zealand complex of species, loosely united in the genus Phreatogammarus, where crangonyctid characters are more predominant, but which 


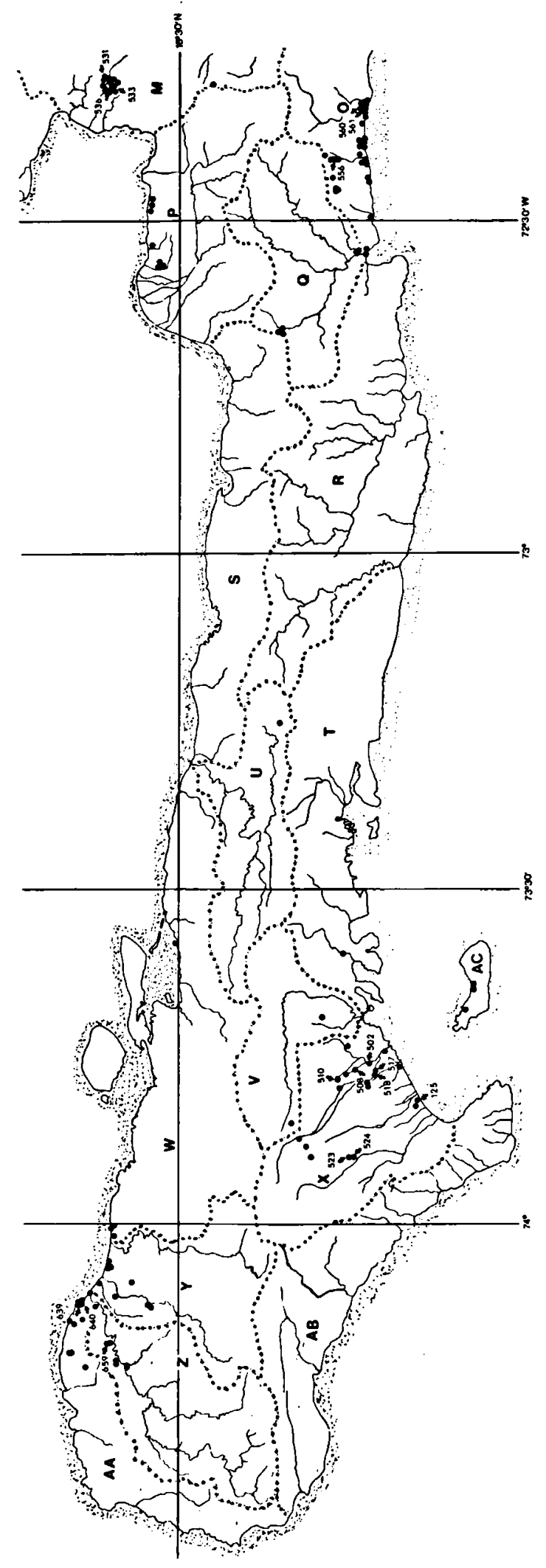

possesses hadzioid/weckelioid traits. If these discoveries will lead to suppression of the family Crangonyctidae as a separate taxon remains to be seen. It is also feasible to create a new family for Crangoweckelia and Pintaweckelia, although the morphology of the Cuban hypogean genus Paraweckelia (which is similar to Crangoweckelia but for the first gnathopod) tends to close the gap with the hadzioids.

Likewise upsetting the existing higher-level taxonomy of the gammaroids is the armature of the palmar margin of gnathopod 2 in Zombiweckelia, Radaweckelia, Apoweckelia, and Croid$z i a$. It was thought that one of the distinctive features of the hadzioids/weckelioids resided in the sexual dimorphism in this armature, in that the male palmar margin is spiniferous, that of the female setiferous. In the four taxa just mentioned, both male and female palmae are spiniferous. In Crangoweckelia and Pintaweckelia even any sexual dimorphism in the gnathopods is absent.

The genus Metaniphargus, the first discovered West Indian genus of the group (Stephensen, 1933), is today also the largest genus in this region (21 species and subspecies). The expression of the sexual dimorphism in the 2nd gnathopod, but especially in the 3rd pleopod, have induced me to distinguish a number of subgenera within Metaniphargus. Most surprisingly, the apomorphous lobes on pleopod 3 of the male may develop on the exopodite, on the

Fig. 4. Distribution of all stations (dots) in area 3 (see fig. 1) of Haiti. Stations with hadzioid/weckelioid Amphipoda are marked by arrows and station number. Nearby localities are not always shown individually. The following hydrographic basins and zones can be distinguished in area 3 (source see fig. 2):

M, Cul-de-Sac zone; O, Cayes-Jacmel/Anse-à-Pitre zone; $P$, Léogane/Carrefour zone; $Q$, Bassin de la Grande Rivière de Jacmel; R, Côtes de Fer/Bainet zone; S, Petite Rivière de Nippes/Grand Goâve zone; T, St. Louis du Sud/Aquin zone; U, bassin de la Grande Rivière de Nippes; V, Bassin de Cavaillon; W, Corail/Anse-à-Veau zone; X, Cayes zone; Y, Roseaux/Voldrogue zone; $Z$, Bassin de la Grande Anse; AA, Jérémie/Les Irois zone; $A B$, Tiburon/St. Jean zone; $A C$, Ile à Vache zone. 
endopodite, or on both rami. Likewise, the entire range of states between (plesiomorphous) magniramous 3rd uropods and (apomorphous) parviramous ones, is represented within Metaniphargus.

Similar transitions can be found in the morphology of the first antenna: with a long, 4-segmented accessory flagellum (a "gammaroid" character) in Radaweckelia and Weckelia, or with a short, 1- or 2-segmented accessory flagellum (a "hadzioid" character) in Apoweckelia, Metaniphargus and others. The 2nd peduncle segment can be long (a "hadzioid/ weckelioid" character), e.g. in Weckelia and Apoweckelia, or short (a "gammaroid" character) in Radaweckelia.

Bousfield (1983) considers the dentition of the left mandibular lacinia mobilis a phylogenetically important character. In certain Haitian taxa however (Haidzia, Hispadzia) the right lacinia shows an aberrant morphology. The phylogenetic significance of this character is still unknown.

Reductions in the mouthparts also characterize the series: the mandibular palp may be long, fully ornamented and 3-segmented (e.g. Metaniphargus), or miniaturized in size and with reduced armature (Zombiweckelia), or 1-segmented and vestigial (Radaweckelia), or even absent (Apoweckelia). Other genera show apomorphous developments in the first maxilla (palps clavate in Bahadzia, inner lobe reduced in size and armature in Apoweckelia).

Taken all together, the West Indian hypogean gammaroids show a scramble of morphological features which upset the current diagnoses of the super-generic units devised so far. This phenomenon does not improve the practicability of the currently advocated divisions of the "good old" Gammaridae. The hypogean gammaroid fauna of Haiti may well prove to furnish a cornerstone for future discussions on the delimitation of higher categories within the group. Why just this island is so rich in taxa remains an enigma to me. From what is known, the gammaroids of Cuba (an island one is tempted to compare with Haiti) are much less diversified. It would be of paramount importance, in my opinion, to obtain knowledge of the stygofauna of the eastern half of Hispaniola and to compare the Haitian fauna with that of the Dominican Republic. Especially because the 13 species of gammaroids described in this paper from Haiti show mostly (very) restricted ranges (see section on zoogeography and fig. 5), it is to be expected that also the eastern half of Hispaniola harbours several endemics, the taxonomic knowledge of which might facilitate the resolution of the higher-level taxonomy of the gammaroids.

\section{ACKNOWLEDGEMENTS}

The fieldwork in Haiti has been supported by grants of the Beijerinck-Popping Fonds, Amsterdam; the Foundation for the Advancement of Tropical Research (WOTRO), The Hague; the Fonds Landbouw Hogeschool, Wageningen; and the Treub Maatschappij, Utrecht.

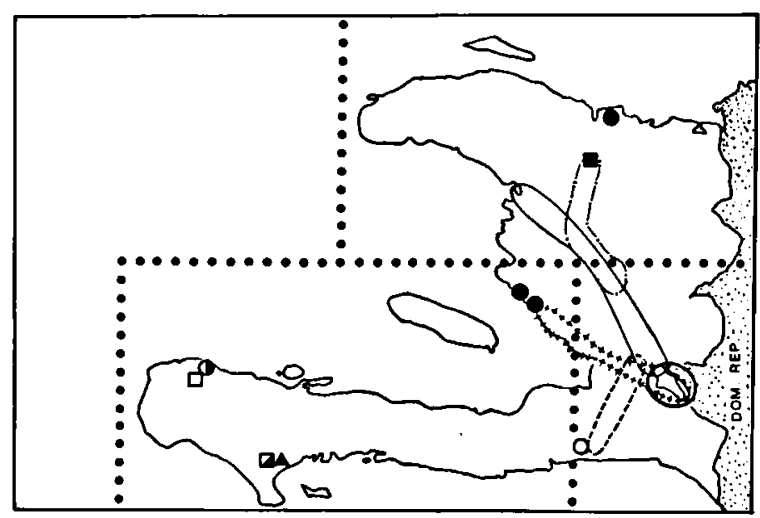

\footnotetext{
Crangoweckelia mixta n. gen., n. sp.

C.spinicauda n. sp.

- Pintaweckelia grandis n. gen., n. sp.

- Metaniphargus haitianus n. sp.

口 M. longipalpus n.sp.

$\{$ M. chaetodactylus n. sp.

M. pedunculatus n. sp.

- $M$. plumicauda n. sp.

- M. crenatus n. sp.

Zombiweckelia parvipalpus n. gen., n. sp.

Radaweckelia brevicauda n. gen., n. sp.

apoweckelia serrata n. gen., n. sp.

Gahadzia latipalpus n.sp.
}

Fig. 5. Ranges of 13 hadzioid/weckelioid amphipod species in Haiti (based on 244 samples of which 51 contained hadzioids/weckelioids). 
The 1978 samples have been taken by Jan H. Stock, Steven Weinberg, and Francisca Zijlstra. The 1979 samples have been taken in great majority by Lazare Botosaneanu and Jos Notenboom, during a short period assisted by John R. Holsinger, Jan H. Stock, and Steven Weinberg. I wish to thank all these collaborators for their zeal under often difficult conditions. The samples are preserved in the Amphipoda collection of the Zoölogisch Museum Amsterdam (ZMA).

The assistance of Mr. Jan J. Vermeulen, who made certain drawings of Pintaweckelia, and of Mr. Louis van der Laan, who made the photograph of the same animal, is gratefully acknowledged.

KEY TO THE HAITIAN GENERA OF HADZIOIDS/ WECKELIOIDS, BASED ON CHARACTERS VISIBLE WITHOUT DISSECTION

1a) Propodus of gnathopods 1 and 2 more or less similar in shape, size and armature ........................ 2

b) Great differences in shape, size and armature of the propodi of gnathopods 1 and $2 \ldots \ldots \ldots \ldots \ldots \ldots \ldots \ldots . \ldots \ldots$

2a) Coxal plate 4 emarginate posteriorly. Basis of pereiopods 5 to 7 elongate-oval, posterior margin convex to straight .......................... Crangoweckelia

b) Coxal plate 4 not emarginate. Basis of pereiopods 5 to 7 very elongate and narrow, posterior margin concave ......................................... Pintaweckelia

3a) Exopodite of third uropod 1-segmented.

b) Exopodite of third uropod 2-segmented.............6 6

4a) Third uropod almost magniramous. Mandibular palp 2- to 3-segmented, usually visible without dissection .. Zombiweckelia

b) Third uropod almost parviramous. Mandibular palp 1 -segmented or absent, not visible without dissection .

5a) Accessory flagellum of first antenna reduced to a 1-segmented vestige

b) Accessory flagellum long, 3- to 4-segmented Apoweckelia Radaweckelia

6a) Endopodite of third uropod wider and longer than exopodite. Telson halves several times longer than wide.

Bahadzia

b) Endopodite of third uropod narrower and shorter than exopodite. Telson halves not much longer than wide.. Metaniphargus

KEY TO THE HAITIAN GENERA OF HADZIOIDS/ WECKELIOIDS, MAINLY BASED ON THE MOUTHPARTS

1a) Mandibular palp overreaching the pars incisiva, 3-segmented ..................................... 2

b) Mandibular palp reduced, shorter than the pars incisiva, 1 - to 3 -segmented, or absent ................ 5

2a) Endopodite of uropod 3 wider and longer than exopodite. Second palp segment of maxilla 1 clubshaped. b) Endopodite of uropod 3 narrower and shorter than exopodite. Second palp segment of maxilla 1 fingershaped

3a) Exopodite of third uropod 2-segmented. Gnathopod 1 much smaller than gnathopod 2 .......... Metaniphargus

b) Exopodite of third uropod 1-segmented. Gnathopods 1 and 2 rather similar in size and in propodal shape and armature

4a) Inner lobe of second maxilla with oblique row of setae . Crangoweckelia

b) Inner lobe of second maxilla without oblique row of setae ..................................... Pintaweckelia

5a) Mandibular palp absent. Accessory flagellum of first antenna 1-segmented........................ Apoweckelia

b) Mandibular palp present. Accessory flagellum 3- to 4-segmented ....................................6 6

6a) Mandibular palp 1-segmented ............. Radaweckelia

b) Mandibular palp 2- or 3-segmented...... Zombiweckelia

\section{ZOOGEOGRAPHIC REMARKS}

The taxonomic study of the hadzioid/weckelioid group of Haiti leads to the following conclusions:

(1) All 13 species of the group are endemic to Haiti.

(2) Of the seven genera represented in our collections, five are endemic to Haiti. One genus (Bahadzia) is also known from anchihaline caves in Great Abaco (Bahamas) and in Providenciales (Turks and Caicos Islands) (Holsinger, 1985); moreover, a representative of this genus, still undescribed, has been collected on the island of Cozumel (Mexico), likewise in an anchihaline cave. Although the Haitian records of Bahadzia are from a number of freshwater localities, without anchihaline features, two localities are quite near to the coast, and the third (Trou Caiman) is located in an area that was inundated by seawater up to the late Pleistocene. The last genus, Metaniphargus, is widely distributed over the calcareous islands of the Antillean arc, but is strikingly absent in the islands of the Bahama Bank. Its origin, like that of Bahadzia, must be sought in the marine realm. Metaniphargus has been divided into a number of subgenera (present paper), of which two (Hispadzia and Haidzia) are endemic to Haiti. One subgenus (Guadzia) is known from Haiti, Guadeloupe and Marie-Galante, where- 
as a fourth subgenus (Caribdzia) is widely distributed, both in the Greater and Lesser Antilles, and even in the coastal area of Venezuela.

This high degree of endemism points to a longer period of isolation of Haiti. Taxonomic affinities of the Haitian genera are not very clear: Pintaweckelia and Crangoweckelia may be related to the Cuban genus Paraweckelia; Bahadzia shows some resemblance to the Mexican genus Mayaweckelia; Zombiweckelia is clearly related to Weckelia from Cuba, and in particular to Alloweckelia from Puerto Rico; and of course Metaniphargus has Antillean affinities.

(3) All freshwater/oligohaline species have only limited ranges within Haiti: they are restricted to one, or a few adjacent hydrographic basins (fig. 5). This seems to point to a strong isolation between these basins. Only one species, Metaniphargus haitianus, is somewhat more widely distributed, but this is a meso/polyhaline species, that presumably can be dispersed in coastal or near-coastal mixohaline waters.

Although the distribution of the samples examined from Haiti is not perfect (figs. 2-4), the total number of samples (244) and the number of samples containing hadzioids/weckelioids (51) make the above conclusions not entirely speculative.

\section{TAXONOMIC PART}

\section{Crangoweckelia n. gen.}

Diagnosis. - Not unlike Paraweckelia Shoemaker, 1959, but with a crangonyctid-like gnathopod 1 (carpus triangular, short; propodus almost as large as that of gnathopod 2; palm oblique, with numerous spines).

Differing from the crangonyctoids in the absence of sternal gills, absence of calceoli, presence of a well-developed, variiramous-type of uropod 3, narrow oostegites, and the presence of a proximoventral spine on uropod 1.
Type-species. - Crangoweckelia mixta n. sp. Other species. - C. spinicauda n. sp.

Etymology. - The confusing mixture of hadzioid/weckelioid and of crangonyctoid characters has inspired the generic name (a contraction of Crangonyx and Weckelia), as well as the specific name of the type-species, mixta. This mixture of characters shows once more that it is very hard, if not impossible, to define higher taxa within the group of genera previously called Gammaridae, notwithstanding several attempts, notably in various papers by Bousfield (refs. in Bousfield, 1983) and by Barnard et coll. (refs. in Barnard \& Barnard, 1983). If it were not for the morphology of the first gnathopod of Crangoweckelia, the new genus could be easily compared with Paraweckelia, from which it differs otherwise in relatively minor characters, viz. (1) several spines on the outer plate of maxilla 1 multidentate (versus 1- or 2-dentate in Paraweckelia); (2) the variiramous state of uropod 3 (magniramous in $P$.), and the length of the 3rd mandible palp segment $(3>1$ in Crangoweckelia, $3=1$ in Paraweckelia).

In general habit, the new genus is strikingly similar to the New Zealand freshwater genus Phreatogammarus Stebbing, 1893 (a crangonyctoid), at least to the hypogean member of that genus, $P$. fragilis (Chilton, 1892). However, $P$. fragilis has sternal gills (cf. Barnard \& Barnard, 1983: 51), lacks inner lobes on the lower lip, has a more complete setal armature of the mandibular palp, has a shortened 3rd peduncle segment in the 1st antenna, and has a magniramous third uropod.

\section{KEY TO THE SPECIES OF CRANGOWECKELIA $(\propto, \uparrow)$}

1a) Sensorial setae of telson shorter than the 2 distal spines. Short spines implanted at some distance of the glabrous tip of the exopodite of uropod 3

C. mixta n. sp.

b) Sensorial setae of telson longer than the single distal spine. Very long spines implanted at the very tip of the exopodite of uropod $3 \ldots \ldots \ldots .$. ..... spinicauda $n$. sp. 
Crangoweckelia mixta n. sp.

(Figs. 6-11)

Material. - One $\sigma^{\circ}$ (holotype), one ovigerous $Q$ (allotype), and sixty-five paratypes. Amsterdam Expeditions to the West Indian Islands, sta. 79-605. Haiti: Dép. de l'Artibonite, Dessalines, well Nord Albert (rue Charlotin), at the foot of a calcareous mountain $\left(19^{\circ} 15^{\prime} 36^{\circ} \mathrm{N} 72^{\circ} 31^{\prime} 15^{\perp} \mathrm{W}\right)$; covered well, dug in sand and gravel; water level at $3.5 \mathrm{~m}$, water depth $6 \mathrm{~m}$; chlorinity 73 $\mathrm{mg} / \mathrm{l}$; temp. 27.3 ${ }^{\circ} \mathrm{C} ; 23$ Nov. 1979 (ZMA Amph. 107.803).

One 9. Sta. 78-223. Dép. du Centre, W. of Mirebalais, on road N109 just W. of crossroad to Saut-d'Eau; in spring of the bank of a small stream $\left(18^{\circ} 51^{\prime} 36^{\top} \mathrm{N}\right.$ $72^{\circ} 10^{\prime} 40^{\circ} \mathrm{W}$ ); moderately fast running, clean, roots, loam; chlorinity and temp. not recorded; 6 May 1978 (ZMA Amph. 107.807).

One specimen. Sta. 78-217. Dép. du Centre, north slope of Mont Blanc, spring no. 6 (estimated position $18^{\circ} 43^{\circ} 42^{\sim} \mathrm{N} 72^{\circ} 07^{\circ} 15^{\nu} \mathrm{W}$ ); clean, fast-running spring; gravel, loam; alt. $300-500 \mathrm{~m}$; chlorinity $30 \mathrm{mg} / \mathrm{l}$; temp. not recorded; 6 May 1978 (ZMA Amph. 107.805).

Two specimens. Sta. 79-584. Dép. de l'Ouest, spring complex called Gongon, on the edge of l'Etang Saumâtre, between the hamlets of $\mathrm{l}^{\prime} \mathrm{Etang}$ and Fond Pite $\left(18^{\circ} 38^{\prime} 54^{\top} \mathrm{N}\right.$ $72^{\circ} 02^{\circ} 06^{\top} \mathrm{W}$ ); rheocrene springs, sand, limestone, rich vegetation; chlorinity $23 \mathrm{mg} / \mathrm{l}$; temp. $22.2^{\circ} \mathrm{C}$; 21 Nov. 1979 (ZMA Amph. 107.806).

Two specimens. Sta. 79-601. Dép. de l'Artibonite, Dessalines, well of Gaby Gabriel (rue Jacques Ier) $\left(19^{\circ} 15^{\circ} 36^{\circ} \mathrm{N} 72^{\circ} 31^{\circ} 01^{\circ} \mathrm{W}\right)$; covered well, dug in alluvia (sand, gravel); chlorinity $143 \mathrm{mg} / \mathrm{l}$; temp. 28.1 ${ }^{\circ} \mathrm{C}$; 23 Nov. 1979 (ZMA Amph. 107.808).

Sixty-five specimens. Sta. 79-602. Dép. de l'Artibonite, Dessalines, well of Darius Belhomme (rue Simonet) (near previous station); partly covered well, dug in alluvia (sand, some gravel); water level at $6.2 \mathrm{~m}$, water depth $2 \mathrm{~m}$; chlorinity $105 \mathrm{mg} / \mathrm{l}$; temp. $28.5^{\circ} \mathrm{C}$; 23 Nov. 1979 (ZMA Amph. 107.810).

Sixteen specimens. Sta. 79-603. Dép. de l'Artibonite, Dessalines, well of Saimval Luisin (corner of rue Christophe and rue Jacques Ier) (near sta. 79-601); large well, partly covered, dug in sand; chlorinity $189 \mathrm{mg} / \mathrm{l}$; temp. not recorded; 23 Nov. 1979 (ZMA Amph. 107.811).

One specimen. Sta. 79-606. Dép. de l'Artibonite, Verretes (quarter Daudad), on the large road along the river, well of Irène Nelson $\left(19^{\circ} 05^{\circ} 46^{\circ} \mathrm{N} 72^{\circ} 29^{\prime} 45^{\circ} \mathrm{W}\right)$; open well in sand; chlorinity $65 \mathrm{mg} / \mathrm{l}$; temp. $25.0^{\circ} \mathrm{C}$; 23 Nov. 1979 (ZMA Amph. 107.804).

Three small (young?) specimens, being in almost all appendages less spiny or setose; their identification remains, therefore, tentative. Sta. 79-609. Dép. de l'Artibonite, Gonaïves, well of Royal Hotel (ca. $250 \mathrm{~m}$ from the sea); covered, clean, pumped well; chlorinity $79 \mathrm{mg} / \mathrm{l}$; temp. 27.5 ${ }^{\circ}$ C; 24 Nov. 1979 (ZMA Amph. 107.809).

Description. - Maximum body length 5-6 $\mathrm{mm}$, but specimens of $31 / 2 \mathrm{~mm}$ have already fully developed oostegites. Body not very slender; unpigmented; blind. Cephalic lobe (fig. 6a) large, rounded; practically no antennal sinus. Urosomites free; somite 1 with a dorsal seta on either side; somite 2 with a spine on either side; somite 3 unarmed (fig. 7e).

Antenna 1 (fig. 6b) longer than the second, about half the length of the body. Peduncle segment $1>2$, segment 3 about half as long as 2 . Accessory flagellum (fig. 6b) 3-segmented, nearly as long as flagellum segments 1 and 2 combined. Flagellum 19-segmented, segments 2 to 18 with an aesthetask (fig. 6b). All antennular segments armed with short setae.

Antenna 2 (fig. 6c) with a strong gland cone. Peduncle segments 4 and 5 elongate and thin, each armed with 3 groups of setae on the ventral margin. Flagellum 12-segmented.

Upper lip (fig. 6d) trapezoidal. Lower lip (fig. 6e) with fleshy inner lobes, separated by a V-shaped cleft.

Mandible: Palp 3-segmented (fig. 8a); segment 1 naked; segment 2 with 3 or 4 ventral setae; segment 3 with 2 or 3 ventral and 3 terminal setae, each seta with a few cilia. Pars molaris (left and right) with a short seta, like in Paraweckelia. Pars incisiva and lacinia mobilis with slight contralateral dimorphism (figs. 8b, c).

Maxilla 1 (fig. 6f): Left and right appendage symmetrical. Palp 2-segmented, distally armed with 4 apical and 1 to 4 subapical setae. Outer lobe with 8 or 9 spines; outer spines with 3 medial denticles, increasing to 6 denticles on the innermost spine. Inner lobe wide, armed with 12-18 plumose setae.

Maxilla 2 (fig. 7a): Inner lobe with median and distal setae and with a diagonal row of some 6 setae.

Maxilliped: Palp segment 3 almost nonlobate; claw with a small nail (fig. 7b). Inner lobe with $3+2$ distal spines, medial margin with 5 setae (fig. 7c). Outer lobe with 10 spines on medial margin, and 2 spines +3 setiform spines on the distal margin (fig. 7d).

Coxal plates 1 to 3 longer $\left(1 \frac{1}{2}-2\right.$ times) than wide (figs. 9a, 10a); ventral margin slightly 


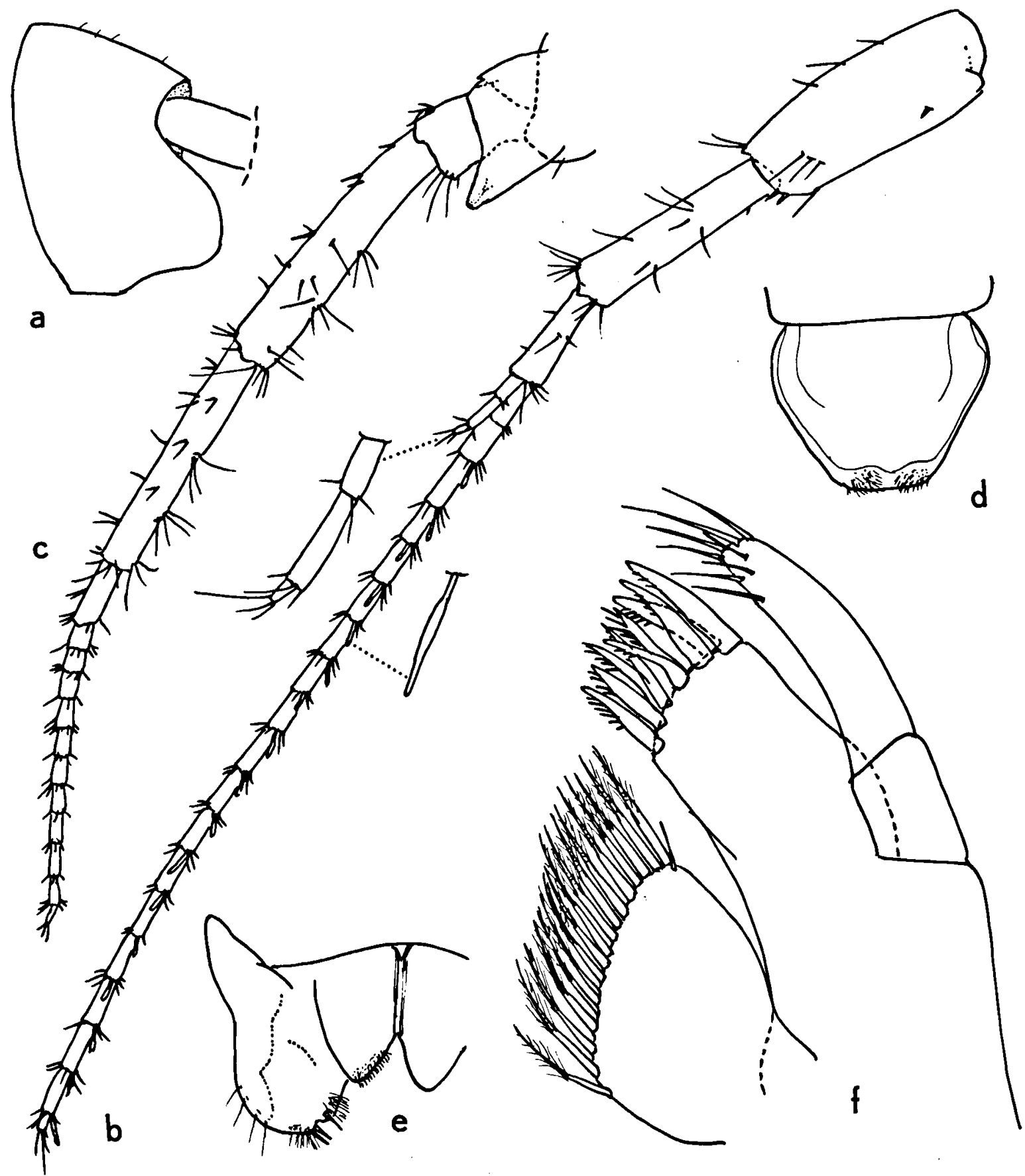

Fig. 6. Crangoweckelia mixta n. gen., n. sp. (sta. 79-605); a, head, ९, from the right (scale 7); b, first antenna, ơ (7); c, second antenna, o (7); d, upper lip, \& (2); e, lower lip, \& (2); f, first maxilla, \& (3). Scales on fig. 11.

curved, armed with 4 to 8 setules. Coxal plate 4 (fig. 9c) hardly longer than wide, with a strong posteroproximal emargination. Coxal gills on 2nd to 6th legs, ovoid, with a short stalk (fig. 10a). Oostegites linear (fig. 9d), on 2nd to 5th legs, armed with long setae on the inner, and short setae on the outer margin.

Gnathopod 1 (fig. 8d): Merus with a patch of spinules. Carpus triangular. Propodus large; palma oblique; palmar angle with 3 setae, 


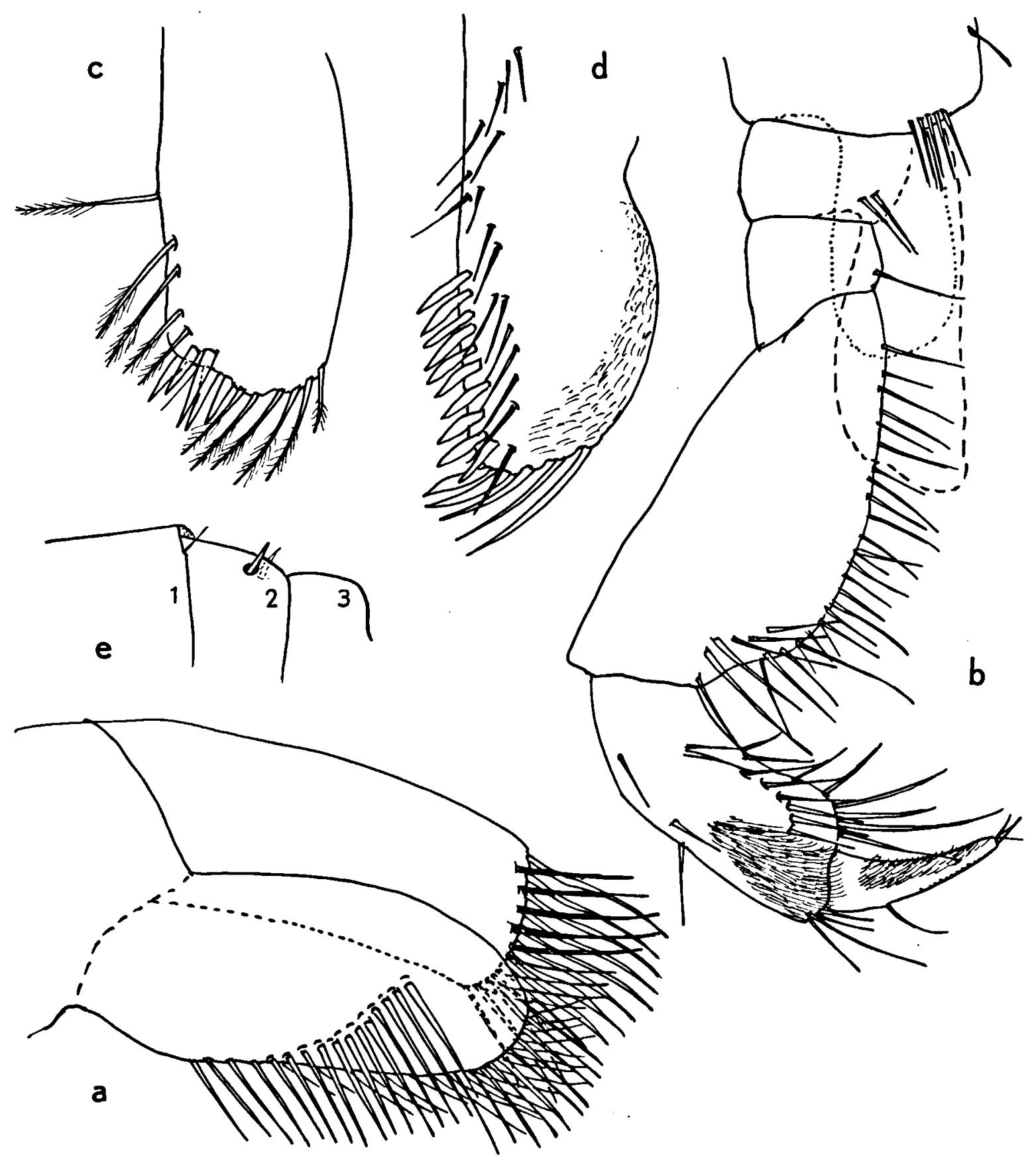

Fig. 7. Crangoweckelia mixta n. gen., n. sp. ( $Q$, sta. 79-605): a, second maxilla (scale 3); b, maxilliped (8); c, inner lobe of maxilliped (3); d, outer lobe of maxilliped (3); e, dorsum of urosomites 1-3 (7). Scales on fig. 11.

palmar margin with ca. 15 pairs of spines of rather regular size, each spine with a posterosubdistal setule (fig. 8f). Free margin of dactylus with 2 setae (fig. 8e).

Gnathopod 2 (fig. 9a) resembling gnathopod
1, propodus somewhat larger than that of Gn.1. No patch of spinules on merus. Palmar angle with 3 short spines and 3 setae. Palmar margin with 19 to 20, often paired, spines (fig. 9b).

Pereiopod 3 (except for the coxal plate) 

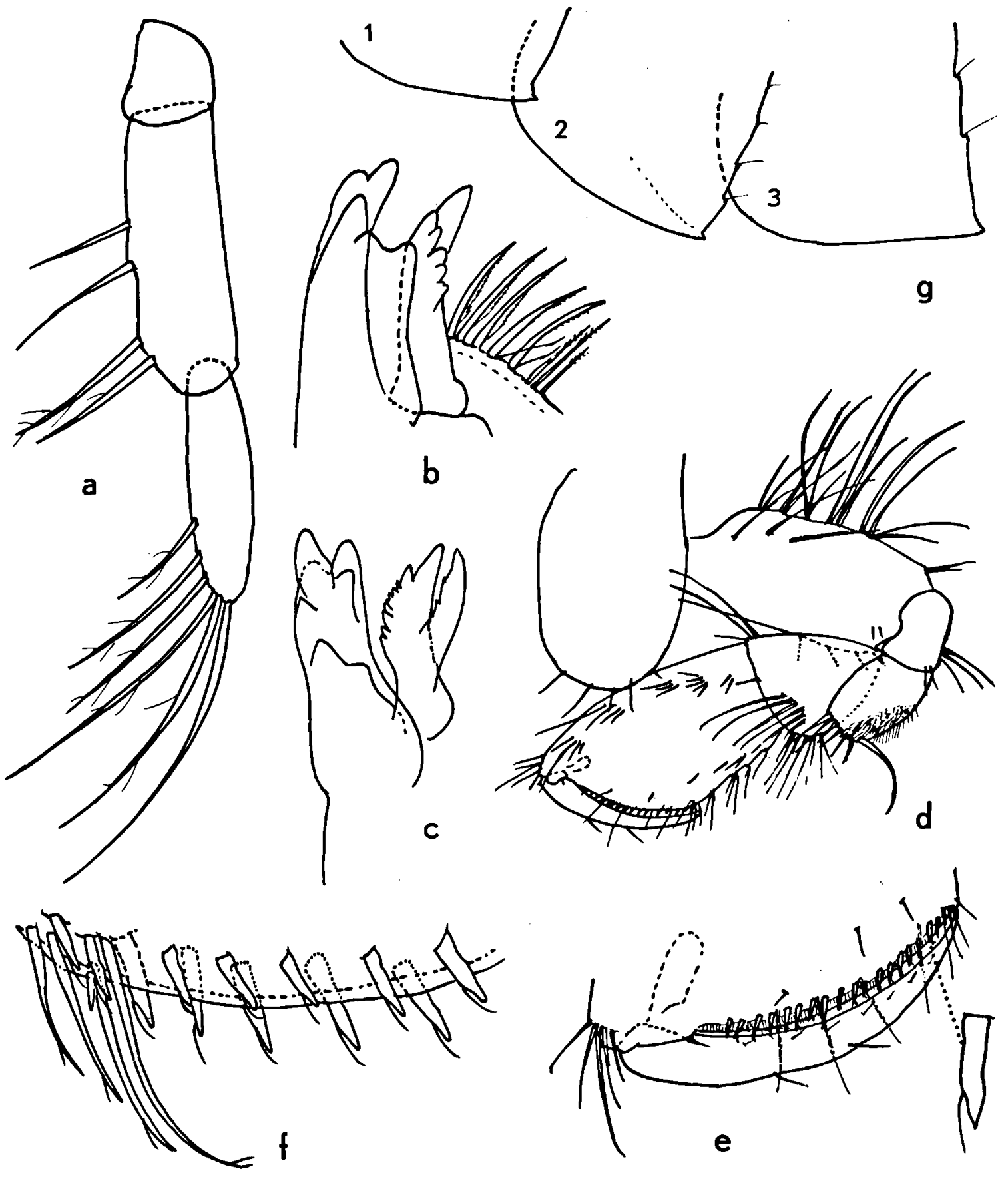

Fig. 8. Crangoweckelia mixta n. gen., n. sp. (sta. 79-605): a, mandibular palp, $९$ (scale 3); b, pars incisiva of left mandible, $\$$ (4); c, same of right mandible, $\$$ (4); d, first gnathopod, $\sigma^{\circ}$ (7); e, palma of first gnathopod, $\sigma^{\circ}$ (2); f, detail of palmar armature of first gnathopod, $\sigma^{\circ}(4) ; \mathrm{g}$, epimeral plates 1-3, $\sigma^{\circ}(7)$. Scales on fig. 11. 


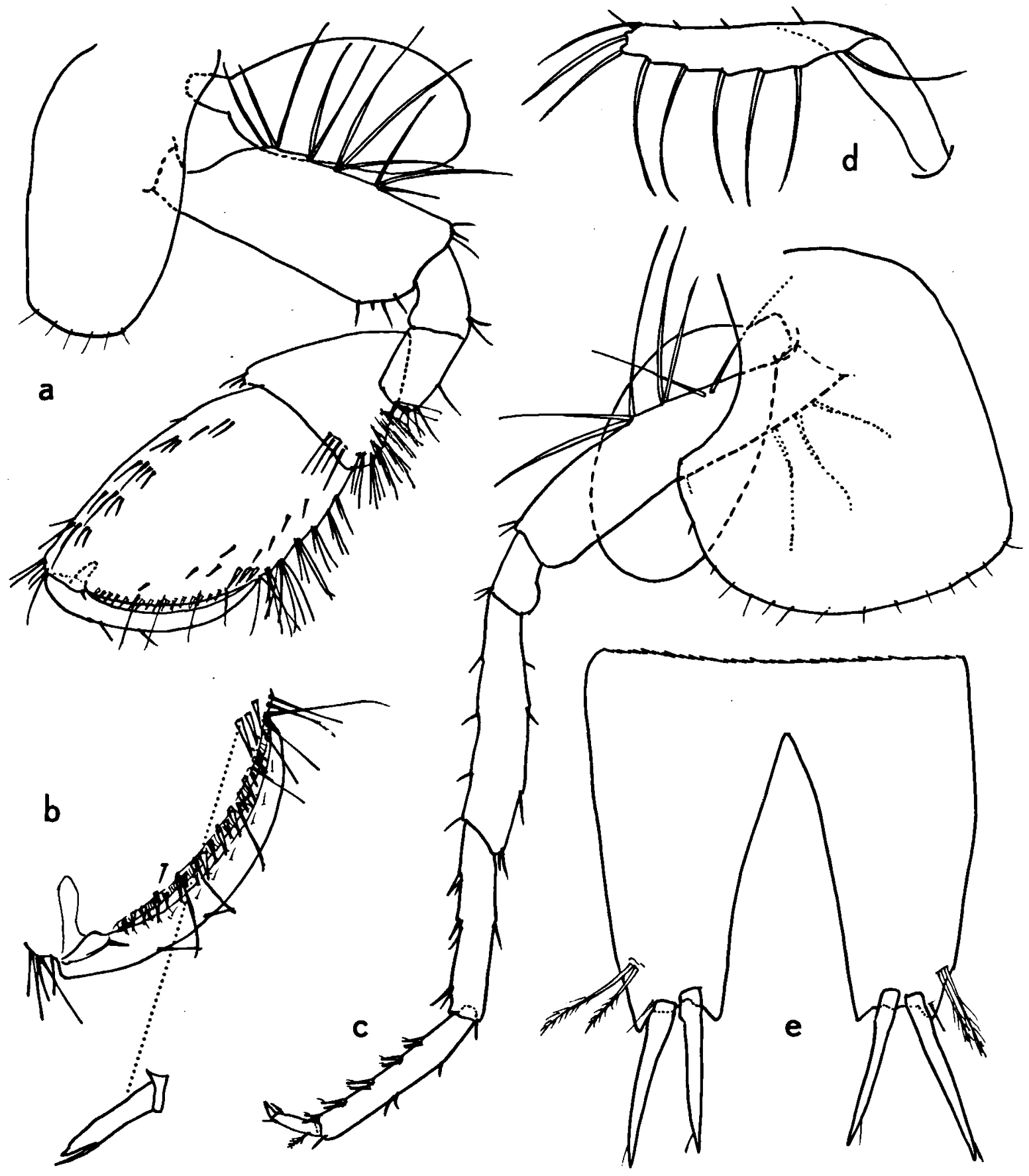

Fig. 9. Crangoweckelia mixta n. gen., n. sp. (sta. 79-605): a, second gnathopod, $\sigma$ (scale 7); b, palma of second gnathopod, $\sigma$ (2); c, fourth pereiopod, $\sigma$ (7); d, oostegite of fourth pereiopod, \& (7); e, telson, $\sigma^{\prime}$ (3). Scales on fig. 11. 


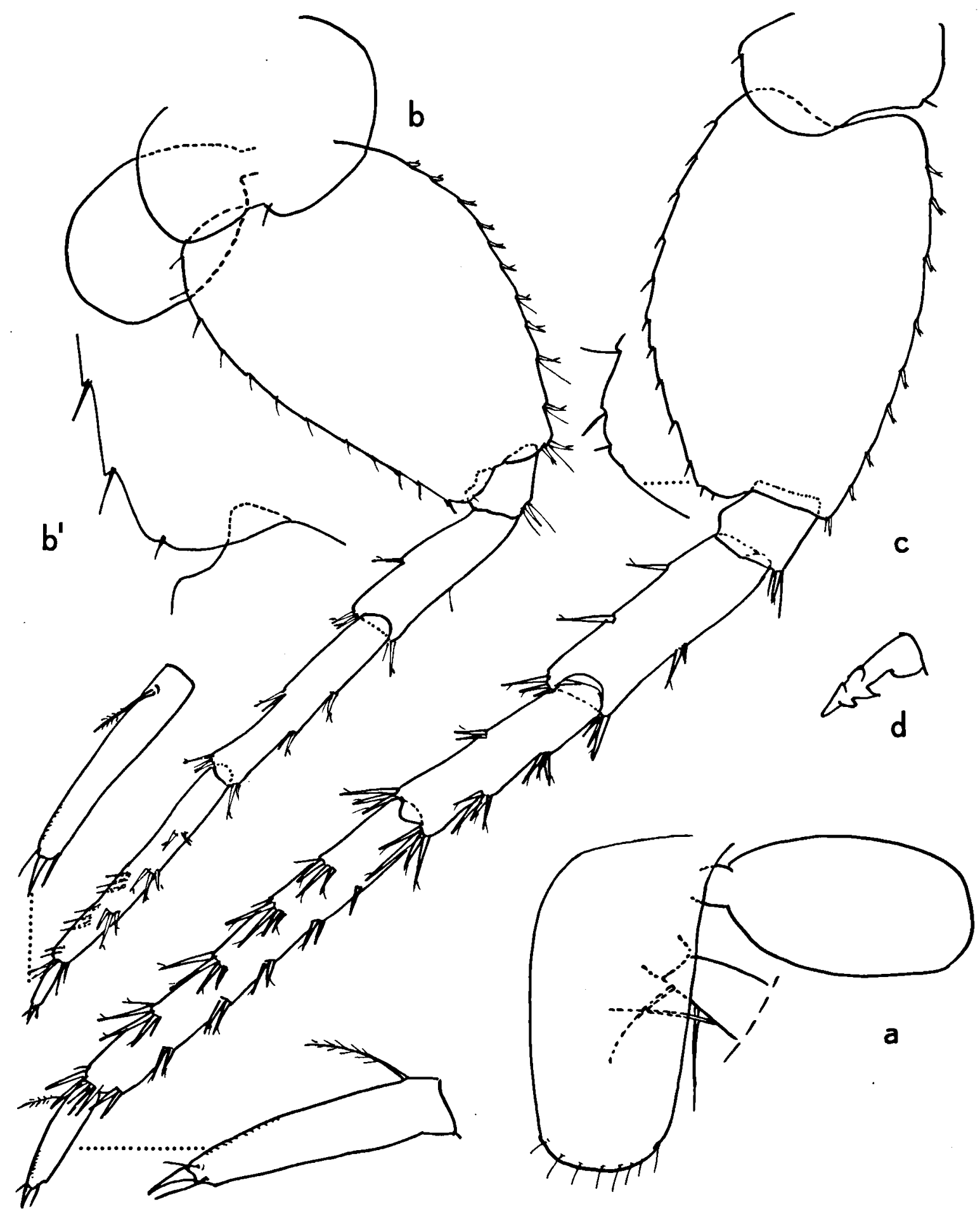

Fig. 10. Crangoweckelia mixta n. gen., n. sp. (sta. 79-605): a, third coxal plate and gill, $\sigma$ (scale 7); b, fifth pereiopod, $\sigma$ (7); b', posteroventral corner of fifth pereiopod, $Q$ (3); c, seventh pereiopod, $\sigma$ (7); d, retinaculum of second pleopod, $\sigma^{\prime}(5)$. Scales on fig. 11. 

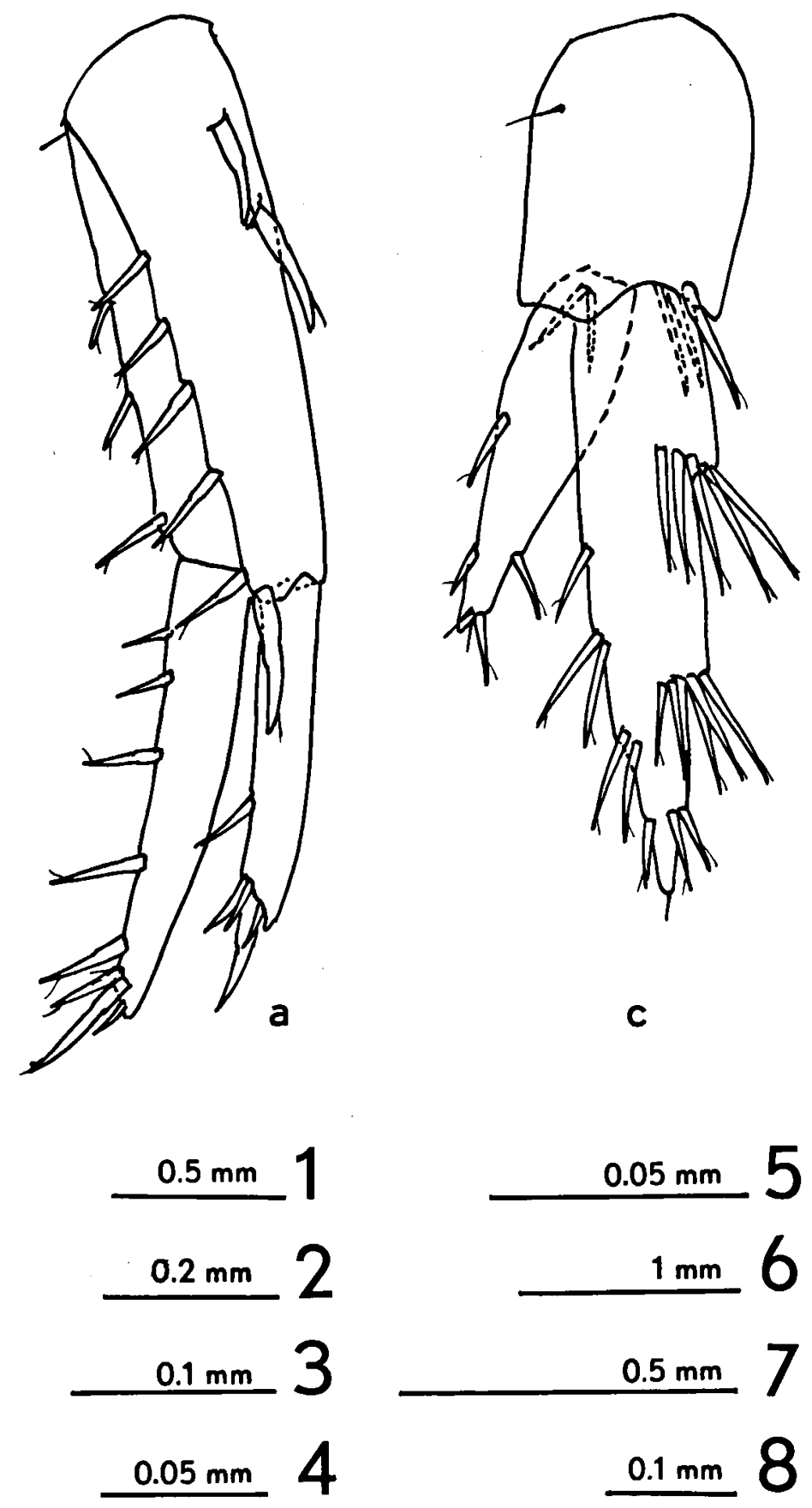
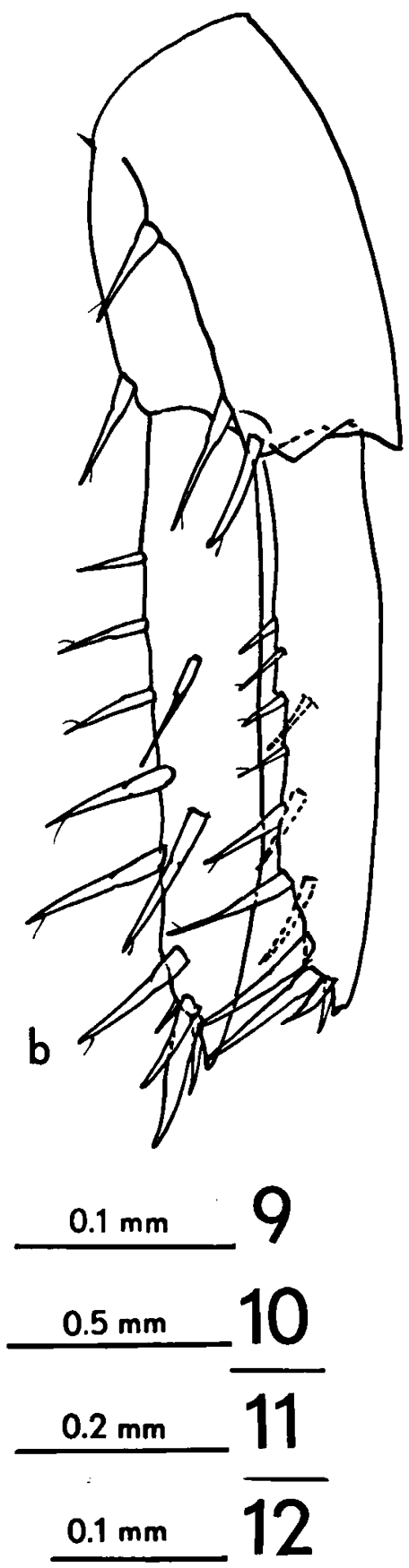

Fig. 11. Crangoweckelia mixta n. gen., n. sp. ( $0^{*}$, sta. 79-605): a, first uropod (scale 2); b, second uropod (8); c, third uropod (8).

similar to P4 (fig. 9c); not setose, slender. Basis of $\mathrm{P} 4$ without spines.

Pereiopod 5 (fig. 10b) shorter than P6 or P7 (fig. 10c), the latter two subequal. Basis roughly ovate, tapering, posterior margin gently curved, posteroventral corner lobed and slightly overhanging (fig. 10b'). Distal segments of P5 to P7 armed with spines, almost devoid of setae.

Pleopods biramous, exopodite 11- to 13-segmented, endopodite 10-segmented; not 
sexually dimorphous. All setae on the rami plumose, but for the most proximal setae on the inner margin of the endopodite, which are bifid (so-called clothpeg spines); there are 4, 3, and 3 clothpeg spines on pleopods 1 to 3 , respectively. Retinacula (fig. 10d) with swollen base, each with 2 marginal hooks.

Epimeral plates (fig. 8g) with almost rectangular posterior corner, each drawn out into a minute point. Posterior margin of plates 2 and 3 with several setules, ventral margin unarmed.

Uropod 1 (fig. 11a): Peduncle with 2 proximoventral spines. Outer ramus shorter than inner ramus, the latter with a row of dorsal spines, the former with 1 or 2 dorsal spines.

Uropod 2 (fig. 11b): Rami subequal, both with spiniferous dorsal margins.

Uropod 3 (fig. 11c) reaching slightly beyond the tip of uropod 2. Peduncle short. Outer ramus 1-segmented, armed with groups of rather long spines, in particular on its lateral margin. None of the exopodite spines reaches beyond the produced tip of the segment. Inner ramus almost $2 / 3$ of the outer ramus, with 1 lateral, 1 terminal, and 2 medial spines.

Telson (fig. 9e) consisting of 2 lobes separated by a narrowly V-shaped cleft, reaching to over $3 / 4$ of the length of the telson. Sensorial setae lateral, close to the tip of each lobe, shorter than the distal spines. Two distal spines on each lobe, no lateral or medial armature.

Sexual dimorphism: None, apart from the presence of oostegites in female and a penial lobe in male. Ovigerous females carry relatively few (1 to 4 ) eggs.

Associated amphipods. - This species may occur together with Crangoweckelia spinicauda and Zombiweckelia parvipalpus.

\section{Crangoweckelia spinicauda n. sp.} (Figs. 12-15)

Material. - One $\$$ (holotype), one $\sigma^{\circ}$ (allotype), three paratypes. Amsterdam Expeditions to the West Indian Islands, sta. 78-224. Haiti: Dép. de l'Ouest, two karst springs on the shore of 1'Etang Saumâtre, E.S.E. of the hamlet Fond Parisien $\left(18^{\circ} 29^{\prime} 19^{\prime} \mathrm{N} \quad 71^{\circ} 56^{\prime} 25^{\prime} \mathrm{W}\right)$; moderately fast running springs, 6 and $4 \mathrm{~m}$ from the shore of the lake; sand, stones, roots; chlorinity $130 \mathrm{mg} / \mathrm{l}$; temp. not recorded; 7 May 1978 (ZMA Amph. 107.800).

Three specimens. Sta. 79-584. Dép. de l'Ouest, spring complex called Gongon, on the edge of l'Etang Saumâtre, between the hamlets of $\mathrm{l}^{\prime} \mathrm{Etang}$ and Fond Pite $\left(18^{\circ} 38^{\prime} 54^{\prime \prime} \mathrm{N}\right.$ $\left.72^{\circ} 02^{\circ} 06^{\top} \mathrm{W}\right)$; rheocrene springs; sand, limestone, rich vegetation; chlorinity $23 \mathrm{mg} / \mathrm{l}$; temp. $22.2^{\circ} \mathrm{C} ; 21$ Nov. 1979 (ZMA Amph. 107.802).

One specimen. Sta. 79-587. Dép. de l'Ouest, village

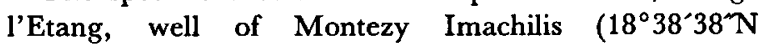
$72^{\circ} 03^{\circ} 48^{\circ} \mathrm{W}$ ); in sandy soil; water level at $5 \mathrm{~m}$, water depth $0.9 \mathrm{~m}$; chlorinity $48 \mathrm{mg} / \mathrm{l}$; temp. $27.8^{\circ} \mathrm{C}$; 21 Nov. 1979 (ZMA Amph. 107.801).

Description. - Body length $7 \mathrm{~mm}$ ( 9 holotype), or $5.5 \mathrm{~mm}$ ( $O^{\circ}$ allotype); paratypes smaller. General aspect very similar to that of C. mixta. The following differences with C. mixta are noticeable:

Antenna 1: Flagellum 18-segmented. Antenna 2: Flagellum 10-segmented.

Mandibular palp (fig. 12e): Third segment very narrow, slightly longer than the second.

Lower lip (fig. 12b): Inner lobes very strongly developed, touching in the midline.

Maxilla 1 (fig. 12f): Outer lobe with 7 spines, 2 of which are bicuspidate, the remaining ones with $2,3,4$ or 5 medial teeth, from lateral to medial. Inner lobe narrow, distally armed with 9 setae only.

Maxilla 2 (fig. 12g): Inner lobe with fewer setae than in C. mixta; diagonal row of some 9 setae.

Maxilliped: Inner lobe with 3 distal spines. Outer lobe with 5 medial spines and 2 spines and 2 setiform elements on the distal margin.

Gnathopod 1 (figs. 13b, 14a): Coxal plate much wider in relation to its length than in $C$. mixta. Palmar margin much longer than the posterior propodal margin. Claw likewise long. Palmar angle marked by one very long spine (fig. 14b).

Gnathopod 2 (fig. 13a): Coxal plate wider and palmar margin and claw longer than in $C$. mixta. Carpus with a somewhat more distinctly lobate posterior margin. Palmar angle armed with 1 very long and 1 shorter spine.

Pereiopod 3 (fig. 14c): Coxal plate wider than in C. mixta. 


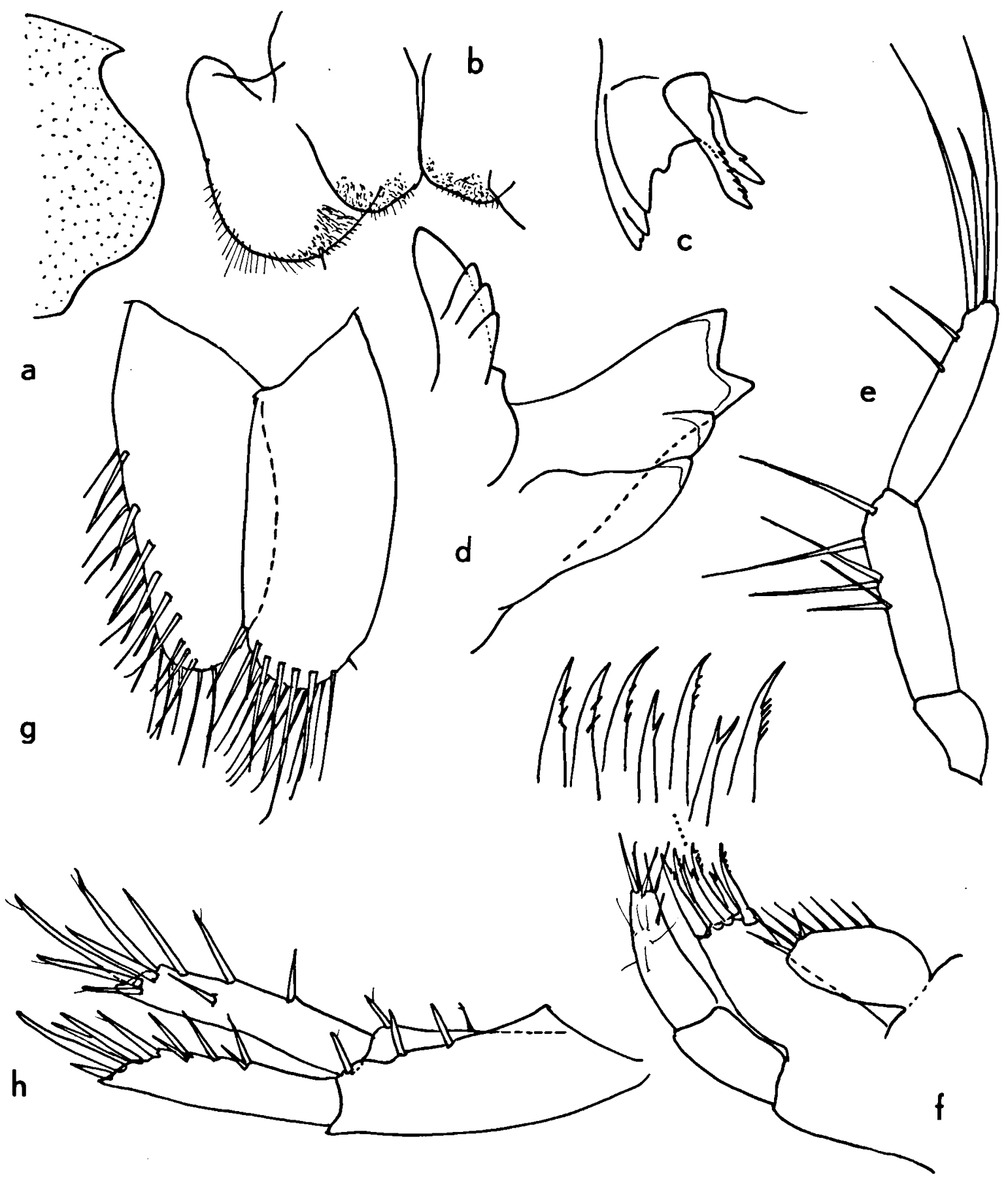

Fig. 12. Crangoweckelia spinicauda n. sp. (sta. 78-224): a, head, from the right, $\sigma^{\prime \prime}$ (scale 7); b, lower lip, $\sigma^{\circ}(8)$; c, pars incisiva of right mandible, $\sigma^{\circ}(4)$; d, pars incisiva of left mandible, $\sigma$ (4); e, mandibular palp, $\$$ (8); f, first maxilla, $\$$ (8); g, second maxilla, $\%$ (3); h, second uropod, $\sigma^{\circ}(2)$. Scales on fig. 11. 


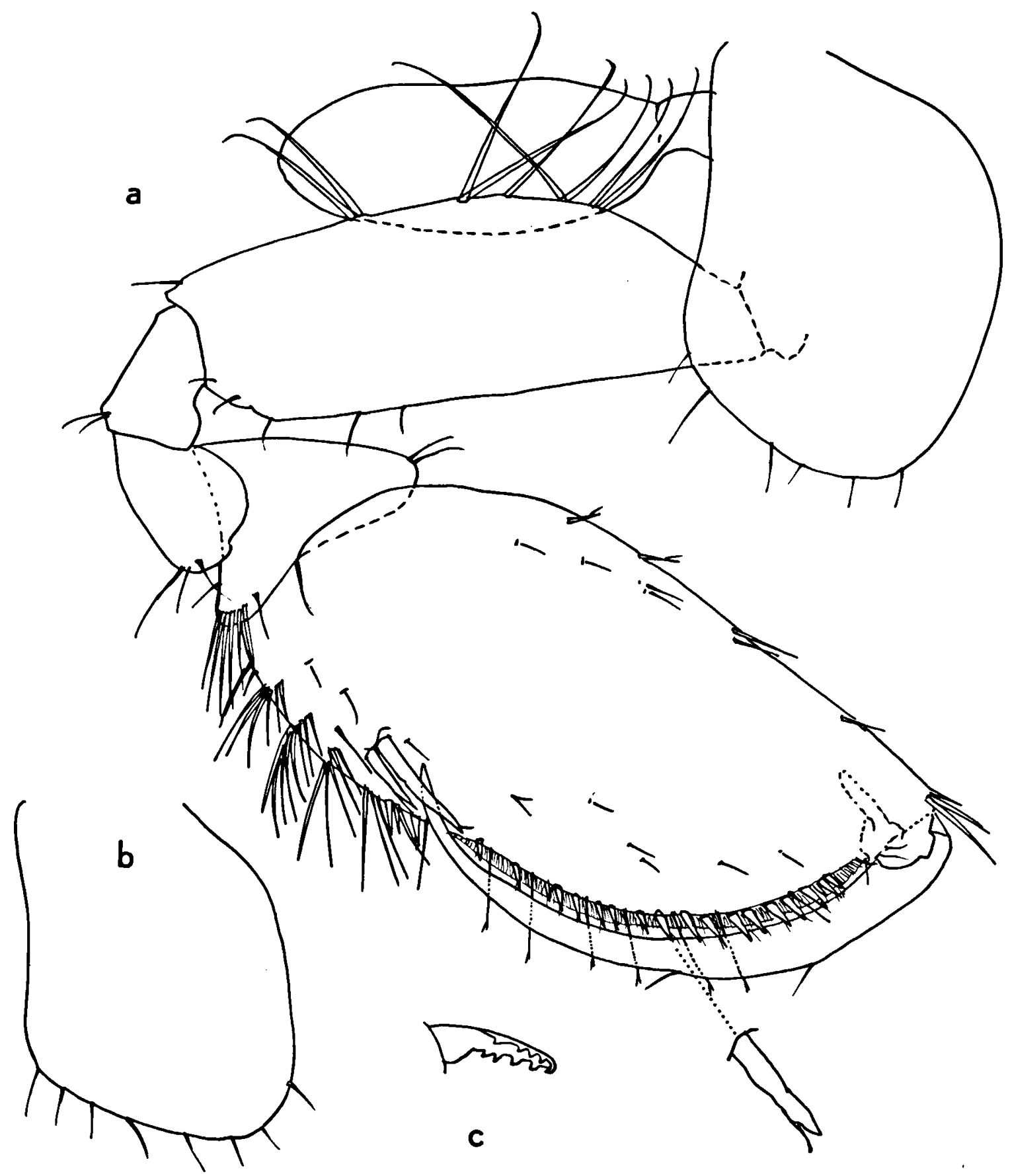

Fig. 13. Crangoweckelia spinicauda n. sp. (sta. 78-224): a, second gnathopod, $\sigma^{\circ}$ (scale 2); b, first coxal plate, $\sigma$ (2); c, retinaculum of first pleopod, $\sigma^{*}(5)$. Scales on fig. 11.

Pereiopod 4 (fig. 14d): Basis with some spines in its distal half. Merus less slender than in C. mixta.

Pereiopod 5 (fig. 15a): Basis less wide than in C. mixta and less lobate posterodistally.
Pereiopods 6 and 7 (fig. 15b): Basis with almost straight posterior margin, not strongly lobate. Carpus more elongate than in C. mixta. Epimeral plates (fig. 15c) with clearly serrate posterior margin. 

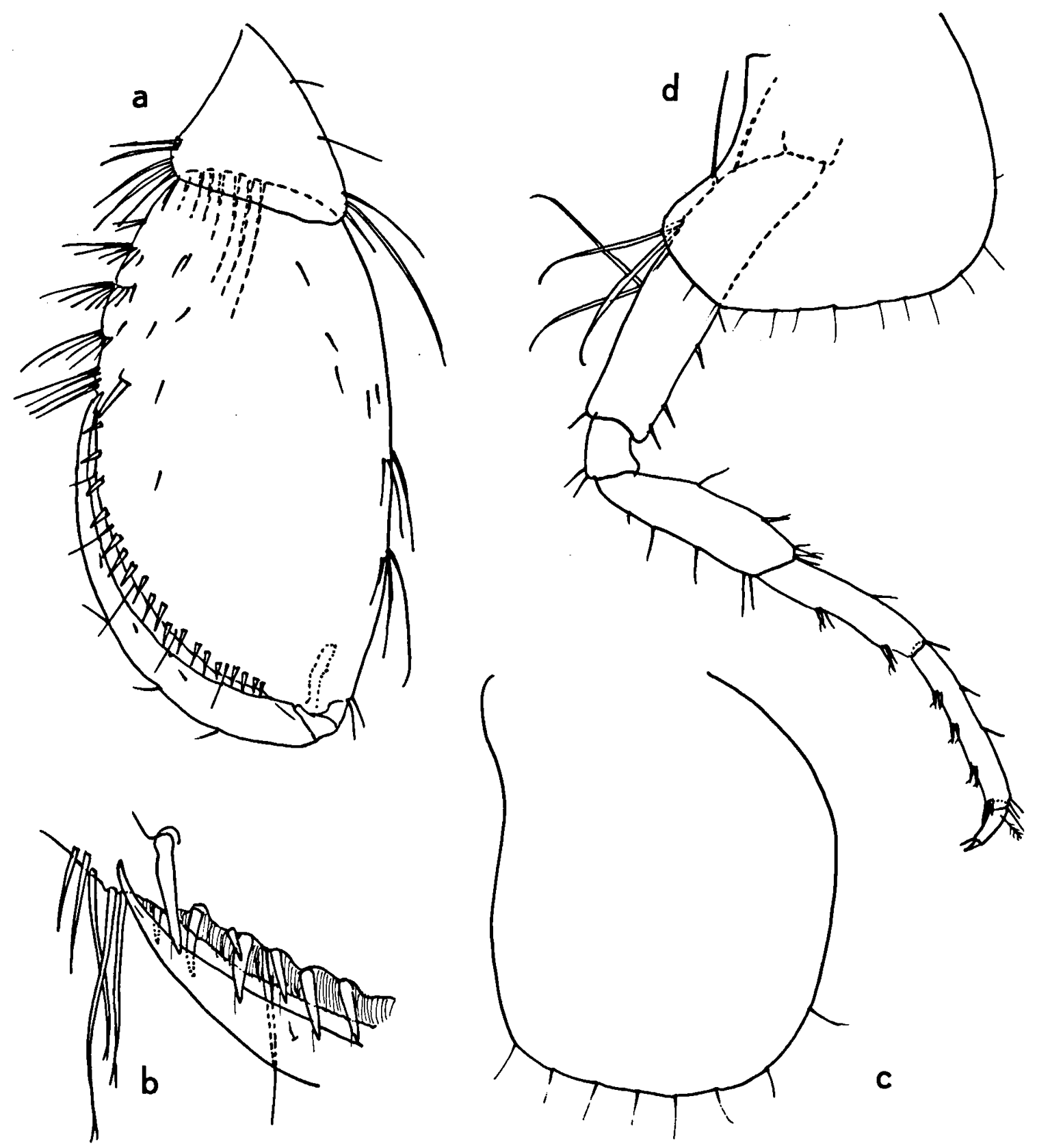

Fig. 14. Crangoweckelia spinicauda n. sp. ( $\sigma^{\star}$, sta. 78-224): a, distal segments of first gnathopod (scale 2); b, palma of first gnathopod (3); c, third coxal plate (2); d, fourth pereiopod (7). Scales on fig. 11.

Pleopodal retinacula (fig. 13c) with 4 pairs of marginal teeth.

Uropod 1 (fig. 15d): The two largest specimens have 1 proximoventral peduncular spine, some of the smaller specimens have 2 such spines. Terminal endopodite and exopodite spines longer than in C. mixta.
Uropod 2 (fig. 12h): Rami with very long spines.

Uropod 3 (fig. 15e): Distal endopite spines and all exopodite spines much longer than in $C$. mixta (the latter reaching far beyond the truncate tip of the segment).

Telson (fig. 15f): Sensorial, plumose setae 

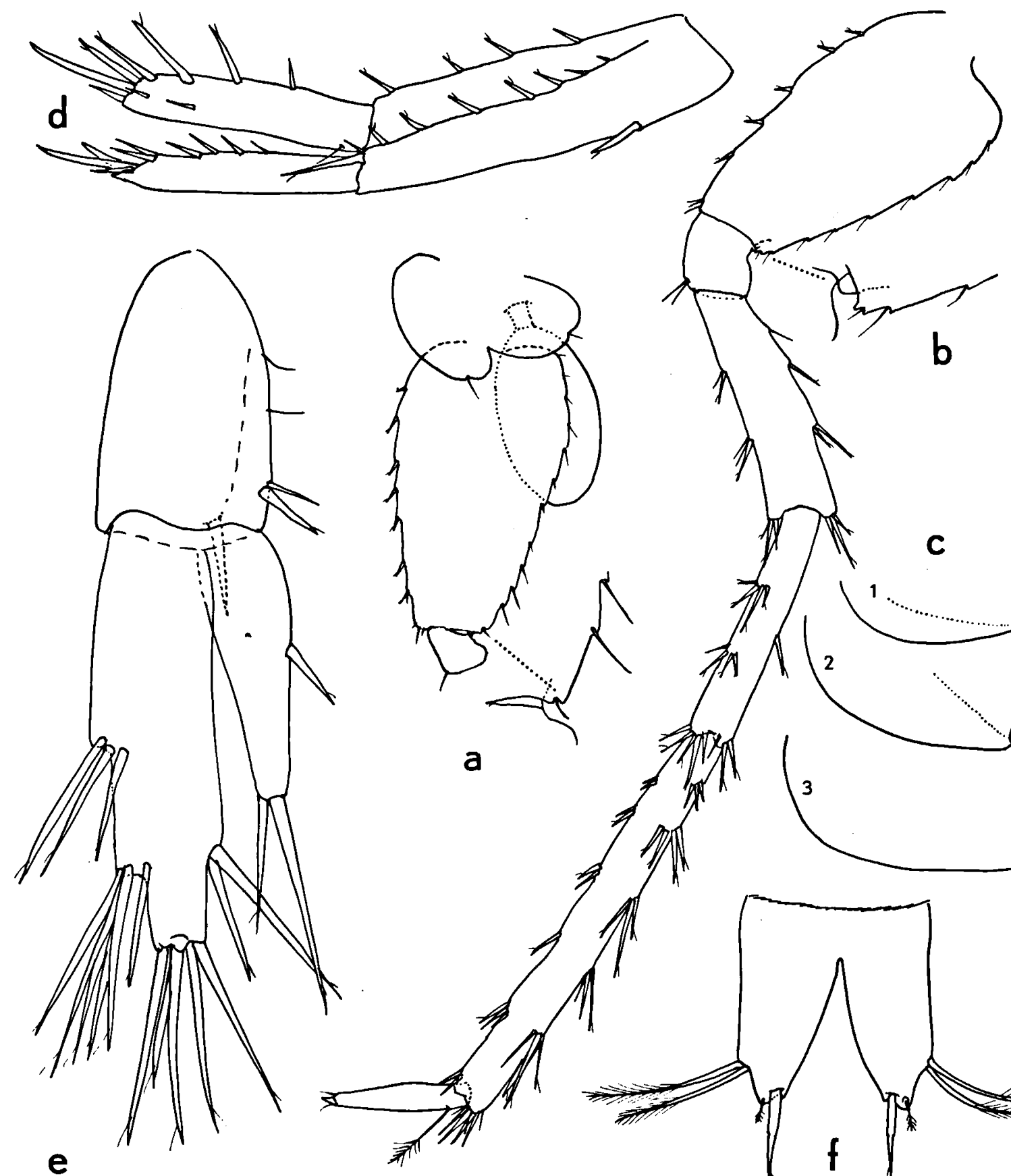

b

Fig. 15. Crangoweckelia spinicauda n. sp. (sta. 78-224): a, basal segments of fifth pereiopod, $\sigma$ (scale 15); b, seventh pereiopod, ơ (15); c, epimeral plates 1-3, O' (15); d, first uropod, ơ (18); e, third uropod, ơ (19); f, telson, \& (16). Scales on fig. 53 . 
longer than the distal spines. One spine on the tip of each half.

No secondary sexual dimorphism.

Remarks. - This species exhibits every salient character of the genus Crangoweckelia (emarginate 4th coxal plate, subequal and subsimilar gnathopods, variiramous 3rd uropods).

Etymology. - The specific name, spinicauda, refers to the long spines on the uropods.

Associated amphipods. - In one station (79/584) this species occurred together with $C$. mixta.

Distribution. - Known from three localities in the Etang Saumâtre-Trou Caiman region of eastern Haiti (hydrographic zone M, cf. fig. 3). The waters in these localities are fresh (23-130 $\mathrm{mg} \mathrm{Cl} / \mathrm{l}$ ), notwithstanding the proximity of brackish lake waters.

\section{Pintaweckelia n. gen.}

Diagnosis. - Very similar to Crangoweckelia (vide supra), but 2nd maxilla without diagonal row of setae on inner lobe, 4th coxal plate not emarginate, basis of pereiopods 5 to 7 very slender, non-lobate.

Remarks. - The differences enumerated above, delicate as they may be, are generally believed to be of generic value in gammaridean amphipods.

Type-species. - Pintaweckelia grandis n. sp. The genus is so far monotypic.

Etymology. - From the "Pinta", one of the two ships with which Columbus continued the discovery of Haiti, after wrecking his flagship, the "Santa Maria", on a reef near Cap Haitien. The specific name grandis alludes to the large size of the type-species.

\section{Pintaweckelia grandis n. sp.}

(Figs. 16-21)

Material. - One $\sigma^{\circ}$ (holotype), one $\$$ (allotype), three paratypes. Amsterdam Expeditions to the West Indian Islands, sta. 79-689. Haiti: Dép. du Nord, Lìmbé, covered, pumped well of the Presbytère (= Rectory) $\left(19^{\circ} 42^{\prime} 14^{\prime} \mathrm{N} 72^{\circ} 23^{\circ} 55^{\circ} \mathrm{W}\right)$; water level at $2.3 \mathrm{~m}$, water depth $1.2 \mathrm{~m}$; clean, sandy bottom; chlorinity $13.8 \mathrm{mg} / 1$; temp. $26.5^{\circ} \mathrm{C} ; 11$ Dec. 1979 (ZMA Amph. 107.838).

Eight specimens (paratypes). Limbé, well at l'Hôpital le Bon Samaritain; 14 Sep. 1981; leg. P. Spangler, R. A. Faitoute and D. Hodges (U.S. National Museum coll. no. USNM 195142).

One $\sigma^{\circ}$, one juv. Sta. 78-241. Village of Camp-Coq (S. of Limbé) $\left(19^{\circ} 40^{\prime} 03^{\prime} \mathrm{N} 72^{\circ} 25^{\prime} 06^{\circ} \mathrm{W}\right)$; well of school on the E. side of road D100; closed well with broken windpump; water level at $2 \mathrm{~m}$, water depth $0.5 \mathrm{~m}$; chlorinity $200 \mathrm{mg} / 1$; temp. not recorded; 10 May 1978 (ZMA Amph. 107.839).

Description. - Body length 5 to $13 \mathrm{~mm}$ (ovigerous female, allotype, $13 \mathrm{~mm}$; illustrated male, holotype (fig. 16), $8.5 \mathrm{~mm}$ ). Blind, unpigmented. Head with very shallow antennal sinus (fig. 17a). Urosomite 1 with a pair of dorsal setules, urosomite 2 with a pair of dorsal spines, urosomite 3 unarmed (fig. 17i).

Antenna 1 (fig. 17b) slightly longer than the second. Peduncle segment 1 slightly shorter than segment 2; segment 3 less than half as long as segment 2. Accessory flagellum (fig. 17c) 4-segmented, as long as the proximal three flagellum segments combined. Flagellum 27-segmented; segments 3 to 25 with an aesthetask.

Antenna 2 (fig. 17e) with very slender 4th and 5th peduncle segments. Flagellum 16-segmented.

Upper lip (fig. 17f) as in Crangoweckelia. Lower lip (fig. 17g) with fleshy, very strong inner lobes.

Mandible: Pars molaris both left and right with a short seta. Pars incisiva with contralateral dimorphism (figs. 18a, b); lacinia mobilis left with 3 coarse teeth, right with 2 irregular and finely toothed cusps. No molar flake. Palp 3-segmented, as illustrated (fig. 18a).

Maxilla 1 (fig. 18c): Palps symmetrical, distally armed with 2 spines and some setae. Outer lobe with 7 spines; these bear (from lateral to medial) $1,1,0,1,2,2$, and 4 medial denticles. Inner lobe wide, armed with 12 to 14 short setae.

Maxilla 2 (fig. 20a): Medial margin of inner lobe setose, but diagonal row of setae absent.

Maxilliped (fig. 18d): Inner lobe with 5 distal 


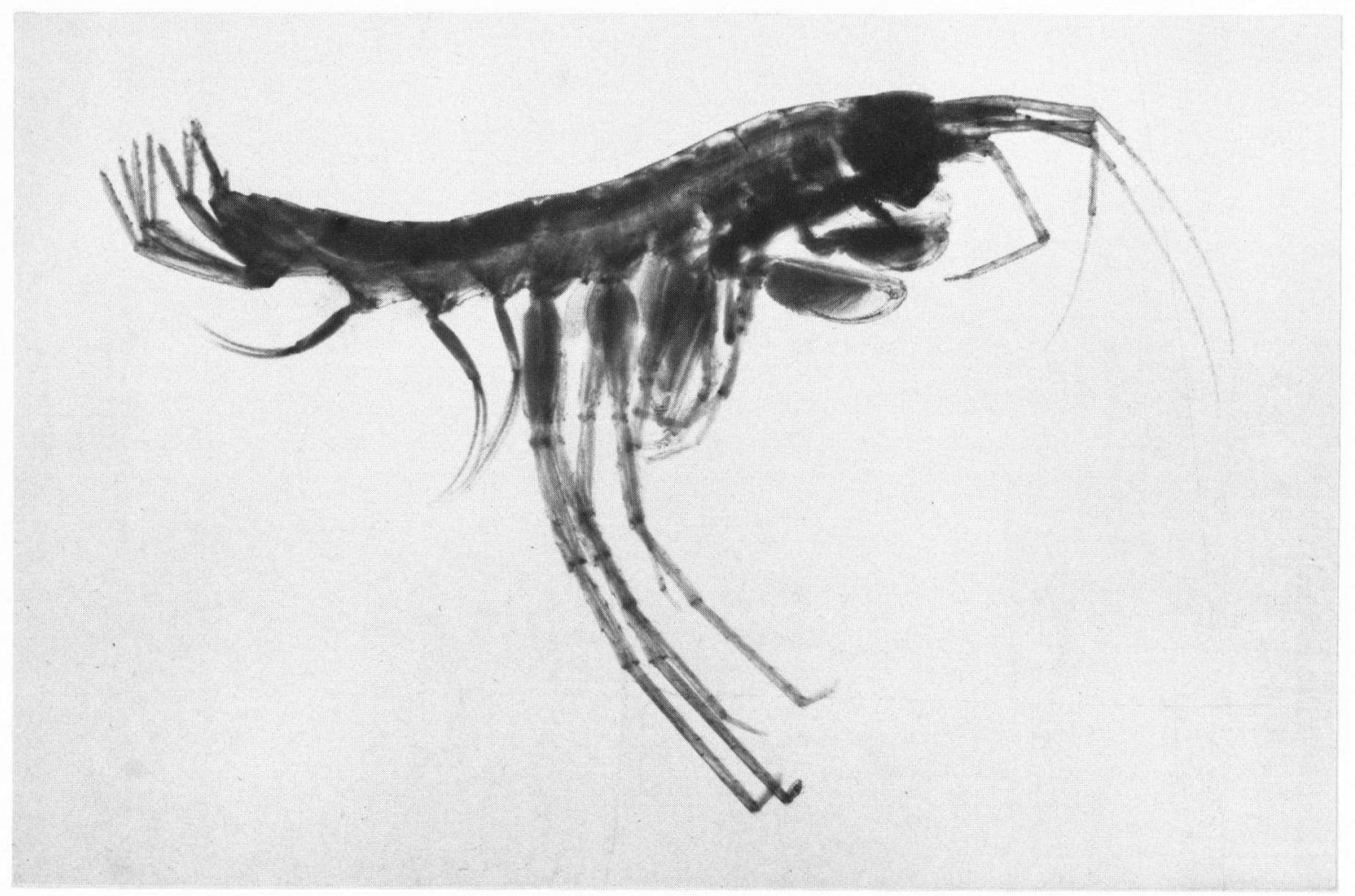

Fig. 16. Pintaweckelia grandis n. gen., n. sp. (sta. 79-689): $\sigma$ holotype, from the right (natural size $8.5 \mathrm{~mm}$ ).

spines and $5+2$ setae. Outer lobe not attaining the middle of palp segment 2. Palp segment 4 not lobate; claw with small nail.

Gnathopod 1 (fig. 19a): Coxal plate parallelogram-shaped, lower margin with some setules. Merus with a field of spinules. Carpus triangular, not lobate. Propodus large, somewhat smaller than that of gnathopod 2. Palmar angle armed with 3 spines, palmar margin with 2 rows, each row of some 16 hair-tipped spines. Palmar margin oblique; claw slender, curved, with 1 seta on outer margin.

Gnathopod 2 (fig. 19b): Coxal plate about as long as wide. Merus without field of spinules. Carpus lobate, triangular. Palmar margin longer than the posterior propodal margin, armed with 2 rows, each row of some 17 hairtipped spines. Palmar angle armed with 3 spines and some setae, placed in a kind of excavation of the propodus.

Coxal gills on legs 2 to 6 , ovate, with short peduncle (figs. 19b, c). Oostegites narrow, linear, setose (fig. 19d), on legs 2 to 5 .

Coxal plate 3 slightly longer than wide (fig. 19c). Coxal plate 4 without posteroproximal emargination (fig. 18e). Distal segments of legs 3 and 4 similar, claws short (fig. 18f).

Pereiopod 5 (fig. 20b) shorter than pereiopod 6 (fig. 20d), the latter slightly shorter than pereiopod 7 (fig. 21b). Claws of P5 to P7 getting progressively longer (figs. 20c, 21a, 21c). Anterior lobe of coxal plates 5 and 6 deeper than posterior one. Basis very slender, tapering, posterodistal corner not produced or overhanging. Long leg segments armed with spines and a few short setules.

Pleopods biramous, each ramus 14- to 16-segmented. Retinacula with 3 or 4 marginal hooks (fig. 19e). No sexual dimorphism. All pleopodal setae plumose, except for the basal setae on the medial margin of the endopodite which are bifid (so-called clothpeg spines, fig. 


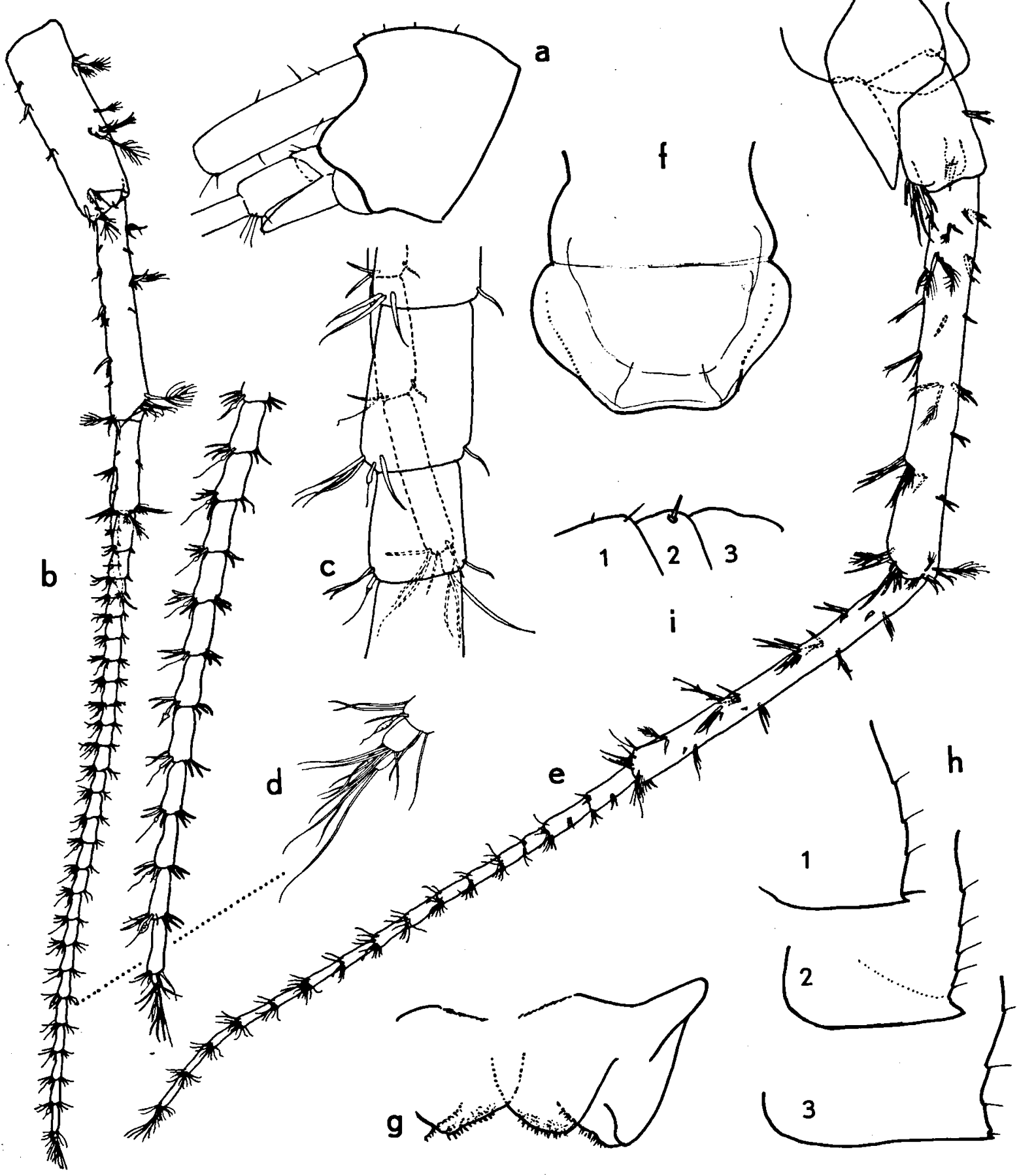

Fig. 17. Pintaweckelia grandis n. gen., n. sp. (sta. 79-689): a, head, $\sigma^{\circ}$, from the left (scale 6); b, first antenna, $\sigma^{\circ}$ (13); c, accessory flagellum, $\sigma^{\circ}(12)$; d, tip of flagellum of first antenna, $\sigma^{*}(12)$; e, second antenna, $\sigma^{\circ}(10)$; f, upper lip, $\$$ (7); g, lower lip, $Q$ (7); h, epimeral plates 1-3, $\odot$ (6); i, dorsum of urosomites 1-3, from the left, $\sigma^{\prime}(6)$. Scales on fig. 11 . 


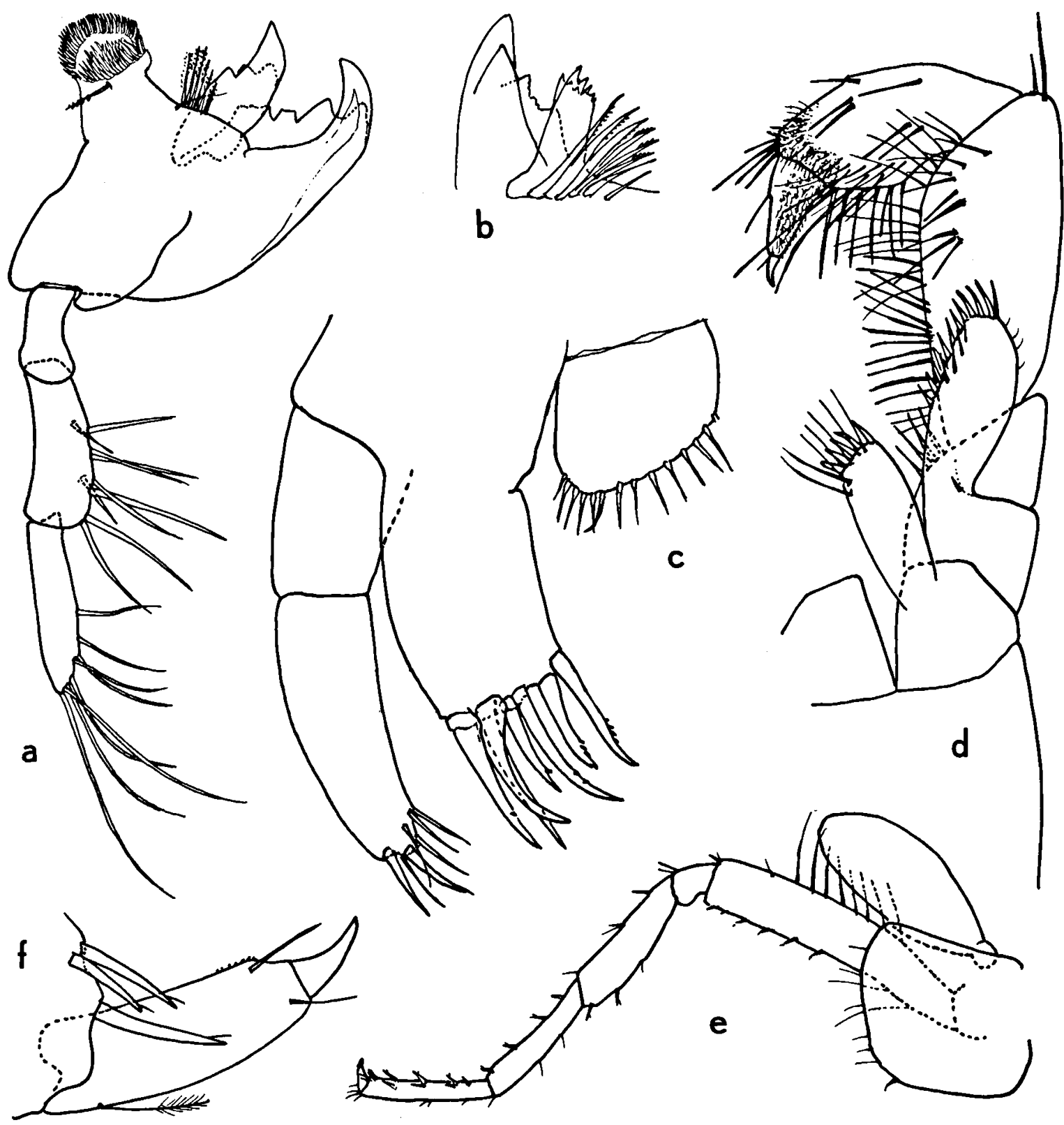

Fig. 18. Pintaweckelia grandis n. gen., n. sp. (sta. 79-689): a, left mandible, $Q$ (scale 2); b, pars incisiva of right mandible, $९$ (2); c, first maxilla, $९$ (8); d, maxilliped, $९$ (7); e, fourth pereiopod, $\sigma^{\circ}(6)$; f, claw of fourth pereiopod, $९$ (3). Scales on fig. 11.

21h). Seven such spines occur on pleopod 1,4 on pleopod 2, and 2 on pleopod 3.

Epimeral plates as illustrated (fig. 17h).

Uropod 1 (fig. 21d) with 1 ventroproximal spine. Both peduncle and rami (which are subequal) richly set with spines.
Uropod 2 (fig. 21e) with slender rami, exopodite slightly shorter than endopodite.

Uropod 3 (fig. 20e) variiramous, not very long. Peduncle not elongated. Inner ramus $2 / 3$ of the outer ramus, both rami 1 -segmented, spiniferous. 


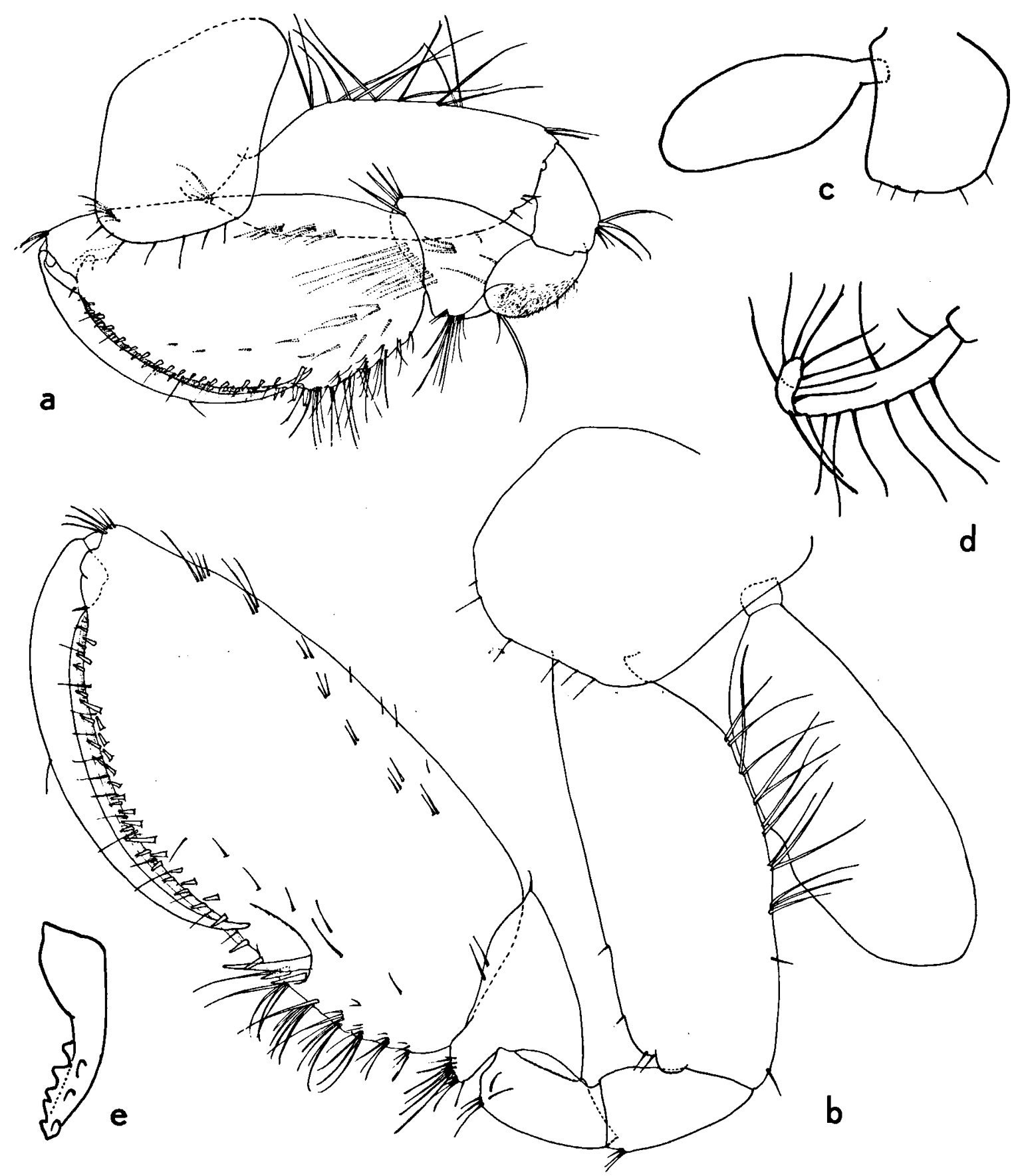

Fig. 19. Pintaweckelia grandis n. gen., n. sp. (sta. 79-689): a, first gnathopod, o (scale 10); b, second gnathopod, ơ (10); c, third coxal plate, $\sigma^{\prime}(6)$; d, oostegite of third pereiopod, $Q$ (6); e, retinaculum of first pleopod, $Q$ (5). Scales on fig. 11.

Telson (figs. 21f, g) with broadly V-shaped cleft, reaching to about $5 / 8$ of the length of the telson. Armature usually limited to the distal end, consisting of 1 long spine, 2 setules and 2 plumose, long, sensorial setae; occasionnally a lateral spine is present (fig. 21f).
Sexual dimorphism: None, apart from the penial lobe $\left(O^{\circ}\right)$ and the oostegites $(Q)$. The ovigerous female (allotype) carried 8 eggs.

Remarks. - Although Pintaweckelia resembles Crangoweckelia by the strong development of the 


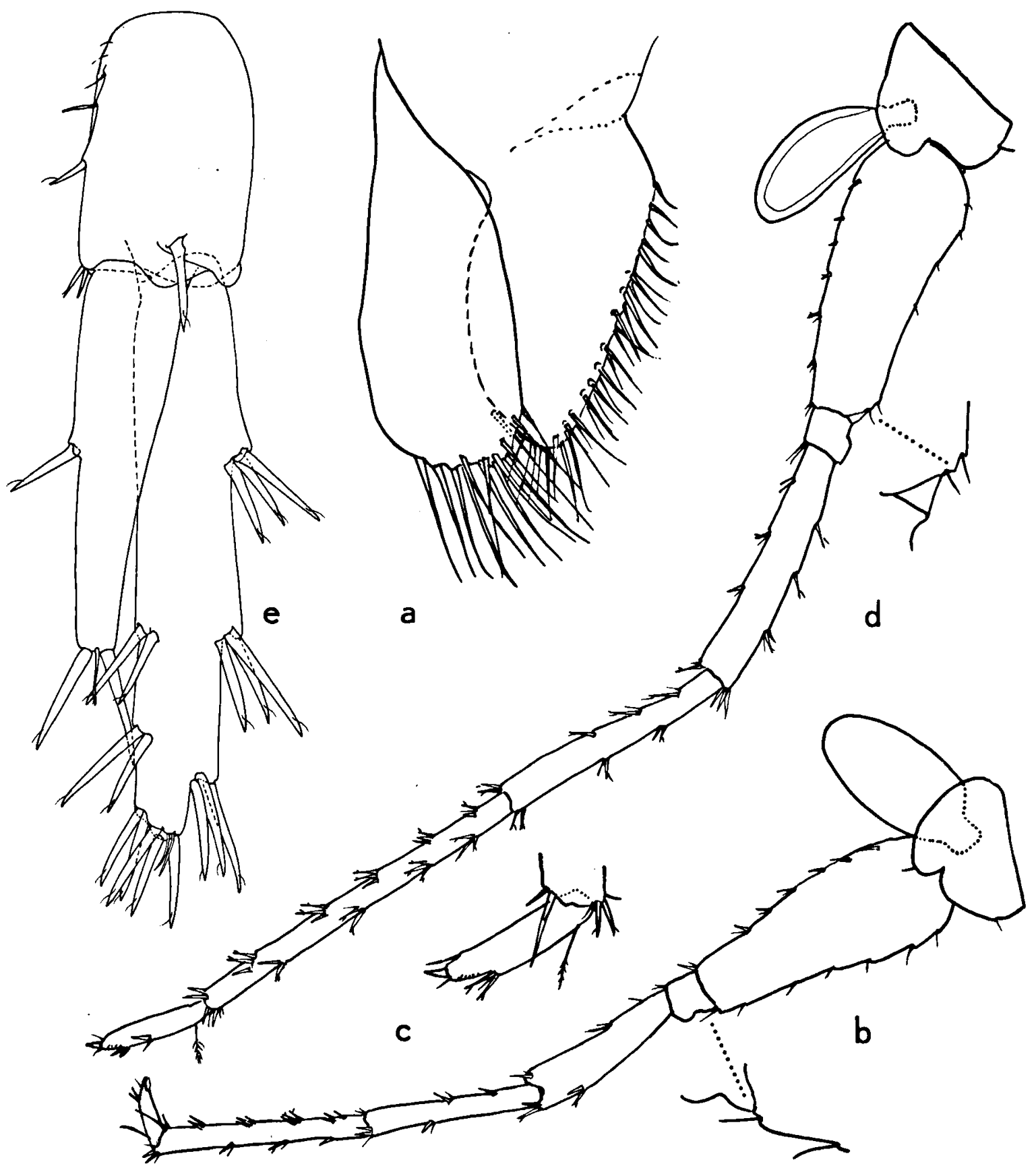

Fig. 20. Pintaweckelia grandis n. gen., n. sp. (sta. 79-689): a, second maxilla, $\$$ (scale 8); b, fifth pereiopod, $\sigma^{\circ}(6)$; c, claw of fifth pereiopod, $\sigma^{\circ}(6)$; d, sixth pereiopod, $\sigma^{\circ}(6)$; e, third uropod, $\sigma^{\circ}(11)$. Scales on fig. 11.

propodus of gnathopods 1 and 2, there are (in addition to the characters enumerated in the diagnosis of the genus) several "smaller" features that keep them apart. Pintaweckelia can attain twice the size of Crangoweckelia; the outer ramus of uropod 3 has a terminal group of spines in $P$., whereas in $C$. mixta (but not in $C$. spinicauda) it ends in an almost unarmed point; the telson shape is different (cleft wider in $P$.); and the basal segments of P5 to P7 have a con- 


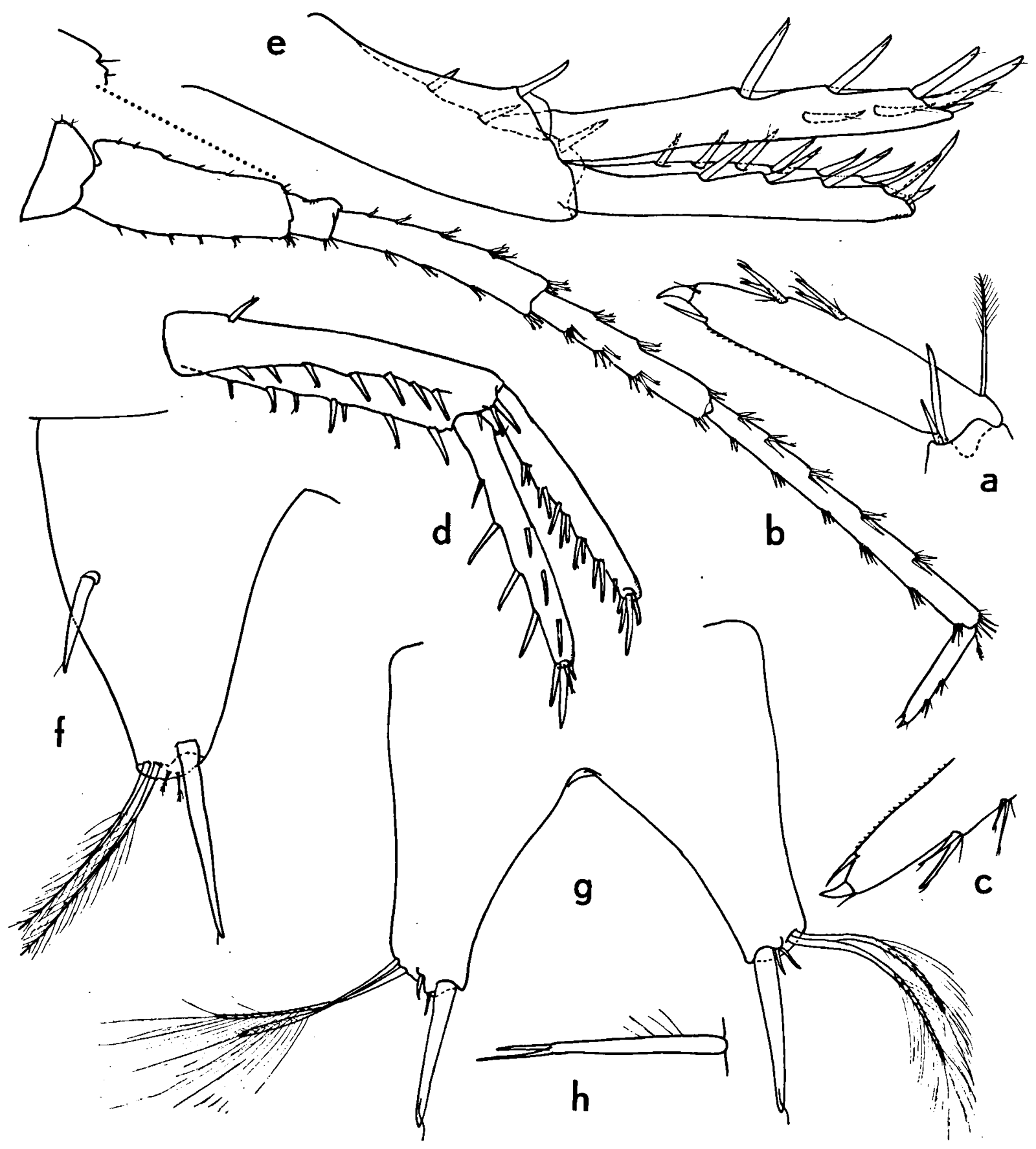

Fig. 21. Pintaweckelia grandis n. gen., n. sp. (sta. 79-689): a, claw of sixth pereiopod, $\$$ (scale 18); b, seventh pereiopod, $\sigma(14)$; c, claw of seventh pereiopod, $\sigma^{\circ}(18)$; d, first uropod, $Q$ (17); e, second uropod, ơ (18); f, telson, \& (19); $g$, telson, $\sigma^{\circ}(19)$; h, clothpeg spine of third pleopod, ơ (20). Scales on fig. 53. 
cave posterior margin in $P$, but a convex to straight margin in $C$.

Distribution. - Known from three wells in a very limited area around Limbé in northern Haiti, all situated in one hydrographic basin (basin F in fig. 2). I am indebted to Dr. Paul Spangler of the Smithsonian Institution, Washington, for a number of perfectly preserved specimens collected by him and some collaborators, which nicely completed our observations on the species based on materials from the Amsterdam Expeditions to the West Indian Islands.

\section{Genus Metaniphargus Stephensen, 1933}

Since my revision of the genus (Stock, 1977a) several new taxa have been discovered. The genus now counts 21 West Indian species and subspecies, which fall into a number of groups, mainly according to the structure of the uropods $\left(\%, O^{*}\right)$, and the degree of sexual dimorphism in the 3rd male pleopods and 2nd gnathopods.

In analogy with previous revisions of West Indian amphipod genera (Ingolfiella - cf. Stock, 1977b; Bogidiella - cf. Stock, 1981), I have decided to elevate the species groups to subgeneric rank. A subgeneric (rather than generic) rank has been choosen, as this procedure allows to identify materials, even in absence of males, at least to generic level, i.e. to the genus Metaniphargus. Since the specific or subspecific differences in the genus are of a refined nature, it is recommended that future descriptions of new taxa will be based as much as possible on both sexes.

\section{DIAGNOSIS OF METANIPHARGUS S.L.}

Hadzioid amphipods. Uropod 3 with 2-segmented exopodite; endopodite narrower and (much) shorter than the exopodite, its armature consisting of spines (and in some taxa also of a limited number of plumose setae). Third male pleopod: basal segments of exopodite (often also of endopodite) fused; setae on fusion complex reduced in length; proximomedial margin of exopodite and/or proximolateral margin of endopodite may form protruding lobes. Telson halves shortened (length and width subequal). Coxal gills, in particular those on P2 to P4 with an articulated stalk. Carpus of $\mathrm{P} 1$ of elongate (= non-triangular) shape, armed with medial, transverse row(s) of setae. Carpus of P2 not lobate; setation marginal. Third segment of mandibular palp with D-setae. Second segment and flagellum of A1 long; accessory flagellum short, 2-segmented.

Type-species (by original monotypy). $-M$. curasavicus Stephensen, 1933.

DIAGNOSES OF THE WEST INDIAN SUBGENERA

Metaniphargus s. str.

Proximomedial part of exopodite of 3rd male pleopod with protruding lobe. Endopodite of uropod $3\left(\%, \sigma^{*}\right)$ short, almost or entirely of parviramous type. Peduncle of uropod 2 ( $q$, $\left.0^{*}\right)$ devoid of distal row of spinules. Right lacinia mobilis finely serrate.

Type-species: $M$. curasavicus curasavicus Stephensen, 1933.

Other taxa: M. c. orientis Stock, 1977a.

Distribution: Endemic to Curaçao.

Guadzia n. subgen.

Proximomedial part of exopodite and proximolateral part of endopodite of 3rd male pleopod with protruding lobe. Endopodite of uropod 3 $\left(\%, \sigma^{*}\right)$ of variiramous type. Peduncle of uropod $2\left(\%, \sigma^{\circ}\right)$ with distal row of spinules. Lacinia as in Metaniphargus s. str.

Type-species: $M$. (G.) bullipes Stock, 1980.

Other taxa: $M$. (G.) juberthiei Stock \& Vermeulen, $1985 ; M$. crenatus $\mathrm{n}$. sp.

Distribution: Marie-Galante, Guadeloupe, Haiti.

Etymology: Contraction of Guadeloupe and Hadzia.

\section{Hispadzia n. subgen.}

Proximolateral part of endopodite of 3rd male pleopod with protruding lobe. Uropod 2 as in Guadzia. Uropod 3 as in Metaniphargus. Right lacinia mobilis with irregular, coarse teeth.

Type-species: $M$. $(H$.$) longipalpus \mathrm{n}$. sp. Other taxa: $M$. (H.) chaetodactylus n. sp. 
Probably belonging to this subgenus: $M$. pedunculatus n. sp.

Distribution: Haiti.

Etymology: Contraction of Hispaniola (the island of which Haiti forms te western half) and Hadzia.

Haidzia n. subgen.

Third male pleopod as in Hispadzia. Endopodite of uropod $3\left(\%, O^{*}\right)$ almost as long as segment 1 of exopodite, armed with spines plus plumose setae (magniramous-like). Uropod 2 as in Guadzia. Differs from all other subgenera in the absence of a coxal gill on $\mathrm{P} 6$, in the reduced number (1 to 3 ) of D-setae on the 3rd mandibular palp segment, and in the reduced armature of the right lacinia mobilis (one cusp untoothed, the other with 1 tooth).

Type-species: $M$. (H.) plumicauda n. sp.

Monospecific.

Distribution: Haiti.

Etymology: Contraction of Haiti and Hadzia.

Jamadzia n. subgen.

Third male pleopod without proximal lobes. Uropods 2 and 3 similar to those of Haidzia. No reduction in number of coxal gills or in number of D-setae. Lacinia mobilis as in Metaniphargus. Type-species: M. (J.) jamaicae (Holsinger, 1975).

Other taxa: $M .(J$.$) craterensis Stock, 1983$.

Distribution: Jamaica.

Etymology: Contraction of Jamaica and Hadzia.

Remark: This taxon covers the jamaicae-group of Stock, 1977a, 1983.

Caribdzia n. subgen.

Differs from Jamadzia in having a short (variiramous) endopodite of uropod $3\left(\%, \sigma^{*}\right)$, devoid of plumose setae.

Type-species: $M$. (C.) nicholsoni Shoemaker, 1959.

Other taxa: $M$. (C.) palpator Stock, 1977a, $M$. (C.) bousfieldi Stock, 1977a, M. (C.) longipes longipes Stock, 1977a, M. (C.) l. christophorensis Stock, 1977a, M. (C.) venezolanus Stock \& Botosaneanu, 1983, $M$. (C.) haitianus n. sp., $M$.
(C.) hyporheicus Stock, 1983, M. (C.) anchihalinus Stock, 1983.

Distribution: Venezuela (coastal), Aruba, Curaçao, Barbuda, St. Martin, Anguilla, Tintamarre, Puerto Rico, Jamaica, Haiti.

Etymology: Contraction of Caribbean and $\mathrm{Had}$ $z i a$, alluding to its wide distribution in the (peri-)Caribbean region.

Remark: This taxon is essentially identical with the nicholsoni-group of Stock, 1977a.

Croidzia n. subgen.

As Caribdzia, but differing from this and all other subgenera of Metaniphargus in the lack of marked sexual dimorphism in the armature of the palmar margin of gnathopod 2: in both sexes, this margin bears spinules (in all other subgenera: spinules in $0^{*}$, setules in $\%$ ).

Type-species: $M$. (C.) beattyi Shoemaker, 1942. Other taxa: Not yet known.

Distribution: St. Croix.

Etymology: Contraction of St. Croix and Hadzia.

Remark: This taxon covers the beattyi-group of Stock, 1977a.

KEY TO THE SUBGENERA OF METANIPHARGUS IN THE WEST INDIES

1a) Palma of Gn. 2 \% armed with spinules Croidzia

b) Palma of Gn. 2 armed with setules............... 2

2a) Uropod 3, inner ramus ( $\left.\%, \sigma^{\circ}\right)$ long, with plumose setae ................................................ 3

b) Uropod 3 , inner ramus $\left(Q, \sigma^{\circ}\right)$ short or mediumsized, devoid of plumose setae ....................4

3a) Pleopod $3\left(\sigma^{\circ}\right)$ with lobe on endopodite. Coxal gills on P2 to P5 $\left(\%, \sigma^{\circ}\right) \ldots \ldots \ldots \ldots \ldots \ldots \ldots \ldots \ldots . . . \ldots \ldots$ Haidzia

b) Pleopod $3\left(\sigma^{\circ}\right)$ non-lobate. Coxal gills on P2 to P6 $\left(\sigma^{\prime}\right.$, \& ) ................................... Jamadzia

4a) Pleopod $3(\sigma)$ non-lobate ................... Caribdzia

b) Pleopod $3\left(\sigma^{\infty}\right)$ lobate $\ldots \ldots \ldots \ldots \ldots \ldots \ldots \ldots \ldots \ldots . \ldots$

5a) Both rami of pleopod 3 ( $\sigma^{\circ}$ lobate ............ Guadzia

b) Only one of the rami of pleopod $3\left(\sigma^{*}\right)$ lobate........6 6

6a) Exopodite of pleopod $3\left(\sigma^{\circ}\right)$ lobate. Pedunculus of uropod $2\left(\sigma^{\circ}, \$\right)$ devoid of distal row of spinules....... Metaniphargus s. str.

b) Endopodite of pleopod $3\left(\sigma^{\circ}\right)$ lobate. Pedunculus of uropod $2(\sigma, \odot)$ with distal row of spinules

Hispadzia

\section{CLADISTICS}

The nine character states used to differentiate between the subgenera of Metaniphargus are 
TABLE I

Character states of the subgenera of the genus Metaniphargus.

\begin{tabular}{|c|c|c|c|}
\hline \multicolumn{2}{|l|}{ State } & \multirow{2}{*}{$\begin{array}{l}\text { Plesiomorphous ** } \\
\begin{array}{l}\text { palma } \pm \text { alike in both sexes } \\
\text { (both spinose) }\end{array}\end{array}$} & \multirow{2}{*}{$\begin{array}{l}\text { Apomorphous** } \\
\text { palmae different ( } \sigma^{*} \text { spinose, } \\
\$ \text { setose) }\end{array}$} \\
\hline 1 & Gnathopod 2, \& & & \\
\hline 2 & Pleopod 3, $\%$ & rami without proximal lobes & $\begin{array}{l}\text { with proximal lobes on (one of) the } \\
\text { rami }\end{array}$ \\
\hline 3 & Nature of pleopodal lobes, $\sigma^{\circ}$ & $\begin{array}{l}\text { present on one of the rami } \\
\text { (either exopodite or endopodite) }\end{array}$ & present on both rami \\
\hline 4 & Endopodite of uropod 3, $\sigma^{\prime}, \$$ & $\begin{array}{l}\text { length } 66-100 \% \text { of } 1 \text { st exopodite } \\
\text { segment; armed with spines plus } \\
\text { plumose setae (approaching } \\
\text { magniramous condition) }\end{array}$ & $\begin{array}{l}\text { length }<60 \% \text { of } 1 \text { st exopodite } \\
\text { segment; armed with spines only }\end{array}$ \\
\hline 5 & $\begin{array}{l}\text { Degree of reduction of endopodite } \\
\text { of uropod } 3,0,9\end{array}$ & endopodite varïramous & $\begin{array}{l}\text { endopodite approaching } \\
\text { parviramous condition }\end{array}$ \\
\hline 6 & Uropod 2, pedunculus, $\sigma^{\circ}$, & with distal row of spinules & spinules lost \\
\hline 7 & 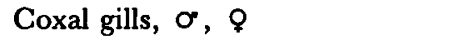 & on $\mathrm{P} 2$ through $\mathrm{P} 6$ & on $\mathrm{P} 2$ through $\mathrm{P5}$ \\
\hline 8 & $\begin{array}{l}\text { D-setae on segment } 3 \text { of } \\
\text { mandibular palp, } \sigma, q\end{array}$ & row of several to many setae & 1 to 3 setae only \\
\hline 9 & Right lacinia mobilis, $\sigma^{\circ}, \propto$ & bicuspidate, both cusps finely serrate & $\begin{array}{l}\text { bicuspidate, cusps not finely ser- } \\
\text { rate, but smooth or with } 1 \text { or } 2 \\
\text { coarse or complex teeth }\end{array}$ \\
\hline
\end{tabular}

** For the determination of the plesiomorphous and apomorphous states, both in-group and sister-group comparisons have been made. As sister-groups, the Bogidiellidae (see Stock, 1981) and the Gammaridae s. str. have been chosen.

enumerated in table I. Based on this evaluation, a cladogram (fig. 22) has been constructed. Each subgenus arises from the cladogram as a mosaic of plesiomorphous and apomorphous characters, but this is not surprising. The parsimony of the cladogram is almost perfect: none of the apomorphies (except state 4) is found more than once. State 4 , the magniramous state of the 3 rd uropod (=plesiomorphous) against the variiramous/parviramous states (= apomorphous), arises 4 times as an apomorphy. This character state apparently is a "weak" one, which developed several times independently. This is not very surprising, since in sister-groups of the hadzioids/weckelioids, such as the Gammaridae s. str., the expression of uropod 3 is likewise weak (examples in the genera Rhipidogammarus, Gammarus, Pseudoniphargus, Niphargus, Psammogammarus, etc.). The state of development of the third uropod is apparently correlated with habitat specialization (magniramous state in free-swimming animals, variiramous and parviramous states in creeping or burrowing animals).
Of course, character state 4 (and state 5 derived from 4) can be omitted from the cladogram, which results in the complete absence of internal parallelism (fig. 23). This procedure might be questionable, since the states of uropod 3 are so currently in use to delimit (sub)genera in Amphipoda. Moreover, the reduced cladogram is less informative, since the distinctions (already weak, because based on synapomorphies and plesiomorphies) between Jamadzia, Caribdzia and Croidzia disappear completely or almost completely.

The other subgenera are all well characterized: Guadzia by the autapomorphous state 3; Metaniphargus s. str. by states 5 and 6; Haidzia by states 7 and 8 .

KEY TO THE HAITIAN SPECIES OF METANIPHARGUS S.L.

1a) Endopodite of uropod 3 with plumose setae; more than $75 \%$ of the length of exopodite segment $1 . . . . . .$. M. plumicauda n. sp.

b) Endopodite of uropod 3 devoid of plumose setae; less than $66 \%$ of the length of exopodite segment $1 \ldots \ldots .2$ 2a) Mandibular palp segment 3 at least $1 \frac{1}{2} \times$ as long as 
segment 2. Endopodite of pleopod $3\left(\sigma^{\circ}\right)$ with lateral lobe.

b) Mandibular palp segment 3 only slightly longer than segment 2. Endopodite of pleopod $3\left(\sigma^{\circ}\right)$ without lobe.

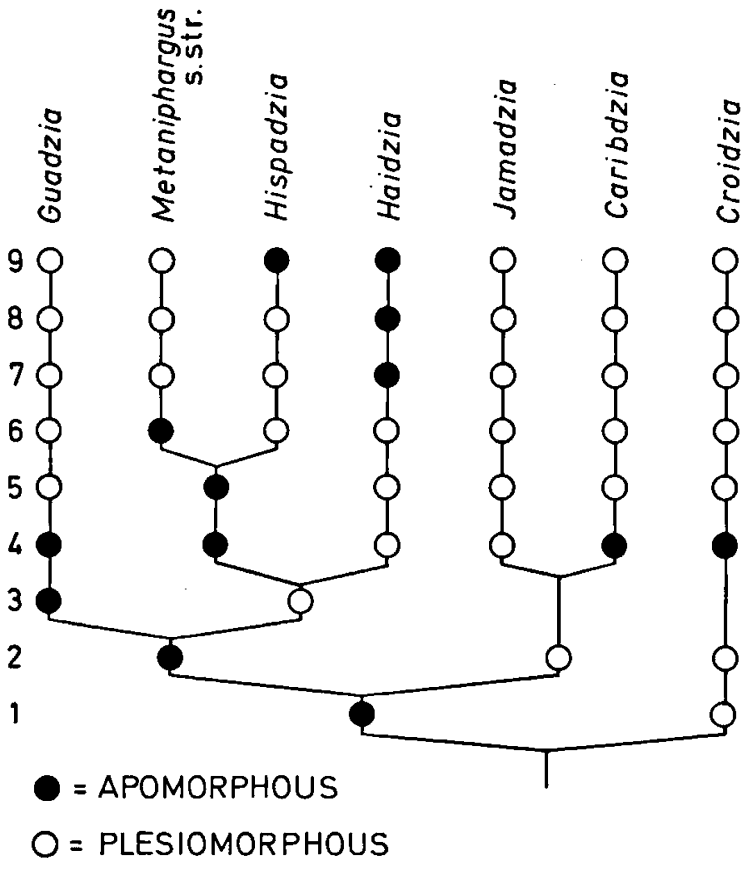

Fig. 22. Cladogram of the subgenera of Metaniphargus, based on 9 character states (see table I). Note the autapomorphy for all states, except state 4 (=third uropod).

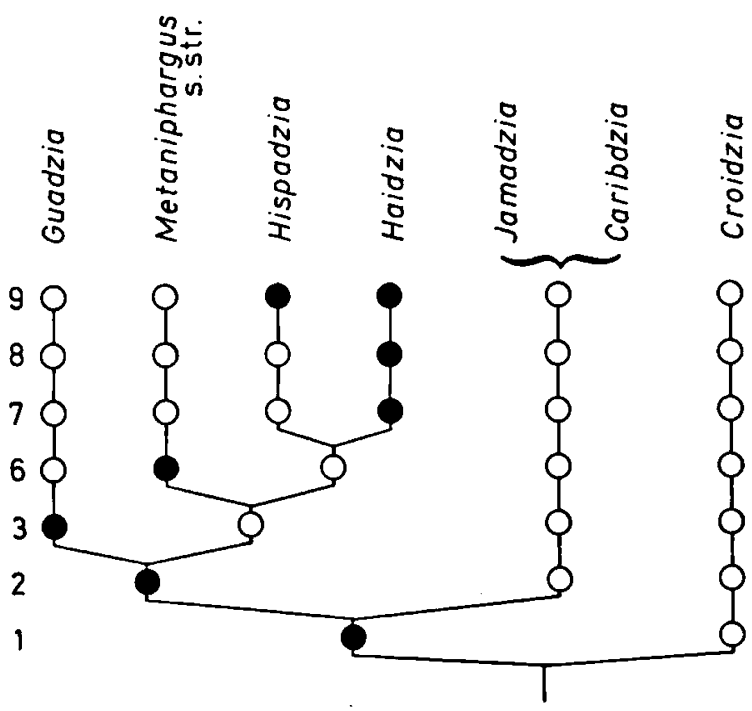

Fig. 23. Same cladogram, with omission of state 4 (and of state 5 derived from 4 ). Note that in this cladogram the resolution into subgenera is less distinct than in fig. 22. 3a) Claw of P5-P7 short and robust. Endopodite of uropod 3 more than half as long as exopodite segment 1 ..................................... pedunculatus $\mathrm{n} . \mathrm{sp}$.

b) Claw of P5-P7 long and slencier. Encopoaite of uropod 3 distinctly less than half as long as exopodite segment 1 ........................................... 4

4a) Dactylus of P5-P7 with setae on outer margin. Telson lobes with medial, distal and lateral soines.

$M$. chaetodactylus $\mathrm{n} . \mathrm{sp}$.

b) Outer margin of dactylus of P5-P7 unarmed. Telson lobes with terminal armature only

$M$. longipalpus n. sp.

5a) Anterior margin of coxal plates 1 to 4 with strong crenulations. Exopodite of pleopod $3\left(O^{\circ}\right)$ with strong medial lobe........................... crenatus $\mathbf{n} . \mathbf{s p .}$

b) Anterior margin of coxal plates 1 to 4 smooth. Exopodite of pleopod $3(\sigma)$ without lobe. $M$. haitianus $n$. sp.

Metaniphargus (Caribdzia) haitianus n. sp. (Figs. 24 c-g, 25-27)

Material. - One ơ (holotype), one $\$$ (allotype), twenty-one paratypes. Amsterdam Expeditions to the West Indian Islands, sta. 78-236. Haiti: Dép. du Nord, open well just N.E. of Cormier-Plage, in an alluvial plain along the coast road, ca. $60 \mathrm{~m}$ from the sea $\left(19^{\circ} 46^{\prime} 13^{\prime} \mathrm{N}\right.$ $72^{\circ} 14^{\prime} 51^{\top} \mathrm{W}$ ); chlorinity $3320 \mathrm{mg} / \mathrm{l}$; temp. not recorded; 9 May 1978 (ZMA Amph. 107.812).

Four $\sigma^{\circ} \sigma^{\circ}$, nine ${ }^{\circ} \propto$ (partly ovigerous). Sta. 79-542, Dép. de l'Ouest, cobble beach of the Golfe de la Gonâve, on the Route du Nord at km 58, near hamlets of Williamson and Lully $\left(18^{\circ} 50^{\circ} 23^{\circ} \mathrm{N} 72^{\circ} 35^{\circ} 06^{\circ} \mathrm{W}\right)$; KaramanChappuis method in pebbles and sand; chlorinity 19998 mg/l; temp. $31.0^{\circ}$ C; 11 Nov. 1979 (ZMA Amph. 107.814).

More than hundred specimens. Sta. 79-615. Dép. de l'Ouest, Trou Baguette, in a drum dug into the sand (forming a primitive sort of well) on the road to Port-auPrince, N.W. of Arcahaie, between Plage Daniel Etelon and the road; distance to the sea ca. $40 \mathrm{~m}\left(18^{\circ} 54^{\circ} 14^{\circ} \mathrm{N}\right.$ $72^{\circ} 37^{\circ} 59^{\circ} \mathrm{W}$ ); in sand; water level at $0 \mathrm{~m}$, water depth 0.2 $\mathrm{m}$; chlorinity $5632 \mathrm{mg} / \mathrm{l}$; temp. not recorded; 24 Nov. 1979 (ZMA Amph. 107.813).

Description. - Body length 3-3.5 mm. In general very similar to $M$. bousfieldi Stock, 1977 a, from Puerto Rico.

Antenna 1 (fig. 26a) about $2 / 3$ of body length. Length of peduncle segments 1 to 3 : 471,373 , and $164 \mu \mathrm{m}$, respectively (thus $2<1$ ). Flagellum 25- to 29-segmented; aesthetasks on segments 9 to 20 in a specimen with 26 flagellar segments. 

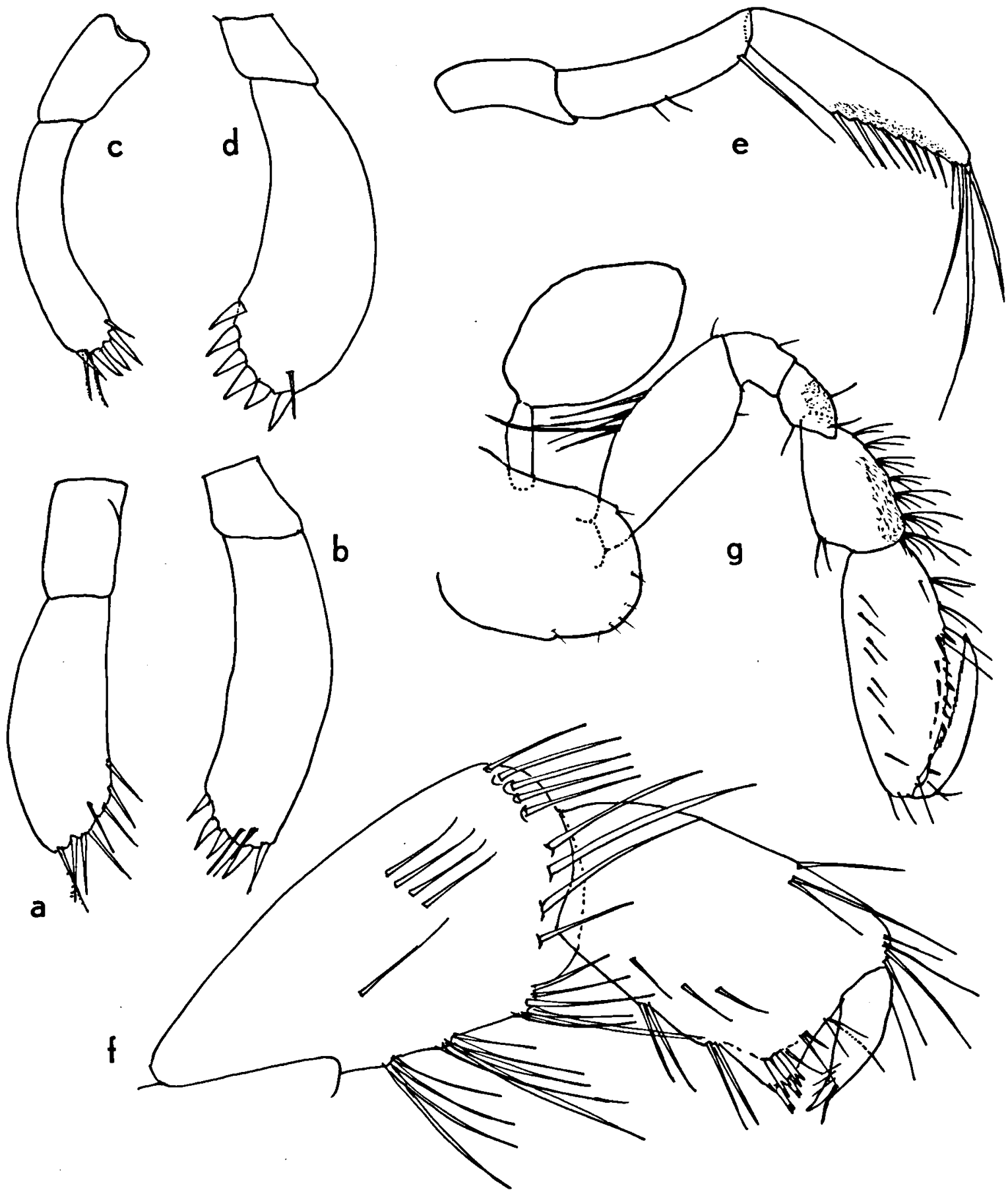

Fig. 24 a-b. Metaniphargus (Caribdzia) bousfieldi Stock, 1977 (topotypic male from Puerto Rico): a, palp of left first maxilla (scale 9); b, palp of right first maxilla (9).

c-g, $M$. (C.) haitianus n. sp. (c, d, and f: sta. 79-542; e, g: sta. 78-236): c, palp of left first maxilla, $\sigma^{*}$ (scale 4); d, palp of right first maxilla, $\sigma^{\circ}(4)$; e, mandibular palp, $९$ (3); f, distal segments of first gnathopod, $९$ ovigerous (2); g, second gnathopod, $\sigma^{*}(2)$. Scales on fig. 11. 
Antenna 2 (fig. 26b) much shorter than the first. Peduncle segments 4 and 5 narrow and slender, 333 and $322 \mu \mathrm{m}$ long, respectively. Flagellum 10-segmented. Gland cone long, slender, slightly down-curved (fig. 26c).

Lower lip without trace of inner lobes.

Mandibular palp (fig. 24e) with rather long first segment; segment 2 with 1 long and 2 short ventral setae; segment 3 with an angular ventral margin, armed with 9 ' $D$ '"-setae, decreasing in size from proximal to distal.

Maxilla 1: First palp segment short; 2nd segment curved, clavate (fig. 24c, d); left and right palp very dissimilar. Outer lobe with 11 distal spines, the inner denticulation of these spines being $2,2,1,2,4,5,9,6,9,9,17$, from lateral to medial. Inner lobe with about 14 setae.

Maxilliped: Lateral margin of coxopodite and of basipodite with a seta.

Gnathopod 1 (fig. 24f) with 3 groups of setae on the posterior margin of the carpus, and 2 groups on the posterior margin of the propodus.

Gnathopod 2 (male) with rather slender, ovoid propodus (fig. 24g). Carpus with 7 or 8 transverse rows of setae; posterior propodal margin with 2 such rows. Palmar angle with 2 long spines; palmar margin with 2 rows of spines of unequal sizes (fig. 25c), about 9 spines in the longest row.

In the female, the propodus of gnathopod 2 (fig. 25a) is more slender than in the male, but smaller in size; the palma is much shorter and so is the claw. Palmar angle with 2 strong spines, palmar margin with shorter and longer setae.

Basis of pereiopods 5 (fig. 26d), 6 and 7 (fig. $26 f)$ slightly lobate, posterodistal corner armed with a setule placed in a small notch. Claws very slender (fig. 26e).

Epimeral plates ending in a small ventrodistal tooth (fig. 26i); posterior margin with 1 setule.

Pleopod 3 of the male (fig. 27a) similar to that of the female. Medioproximal margin of the endopodite of pleopods 1 to 3 each with 1 clothpeg spine.

Uropod 1 (fig. 27b): Dorsal margin of pedunculus and rami with reduced number of spines.
Uropod 2 (fig. 27c): Pedunculus with distal row of 3 to 6 small spinules and 2 longer spines; exopodite with none or one spine on the dorsal margin; endopodite with 1 or 2 spines on the dorsal margin.

Uropod 3 (fig. 26h): Endopodite pointed, almost half the length of the 1st exopodite segment; 2nd exopodite segment not very long, about twice the length of the distal spines on segment 1 . In other samples, the endopodite is slightly shorter than in the type-specimens, viz. $35-40 \%$ of the 1 st exopodite segment. In these specimens, the endopodite is devoid of lateral spines (fig. 26g).

Telson (fig. 27d) completely cleft; each lobe longer than wide, sensorial setae at about $2 / 3$ of the length; armature restricted to distal margin, consisting of 3 or 4 spines.

The remaining appendages are very similar to those of $M$. bousfieldi.

Remarks. - This species belongs clearly to the subgenus Caribdzia. As remarked before (Stock \& Botosaneau, 1983), the taxa within this group are characterized by very refined differences only. Since all taxa are allopatric, it is a matter of taste whether they are considered species or subspecies. The presently described form from Haiti forms no exception. It is very similar to its closest geographic relative, $M$. bousfieldi from Puerto Rico. M. haitianus is mainly distinguished by its smaller body size, the reduced spination of the uropods, the shorter second peduncle segment of $\mathrm{A} 1$, the relatively low number of groups of setae on the posterior margin of carpus and propodus of gnathopod 2 in both sexes, and the greater asymmetry of the left and right palp of the first maxilla (cf. figs. $24 \mathrm{c}$, d for haitianus, with figs. $24 \mathrm{a}, \mathrm{b}$ for bousfieldi).

Distribution. - This is a form from nearcoast, salty localities, and it is not surprising, therefore, that is has been found in two wellseparated zones in Haiti (hydrographic zone G in fig. 2 and zone $L$ in fig. 3). 


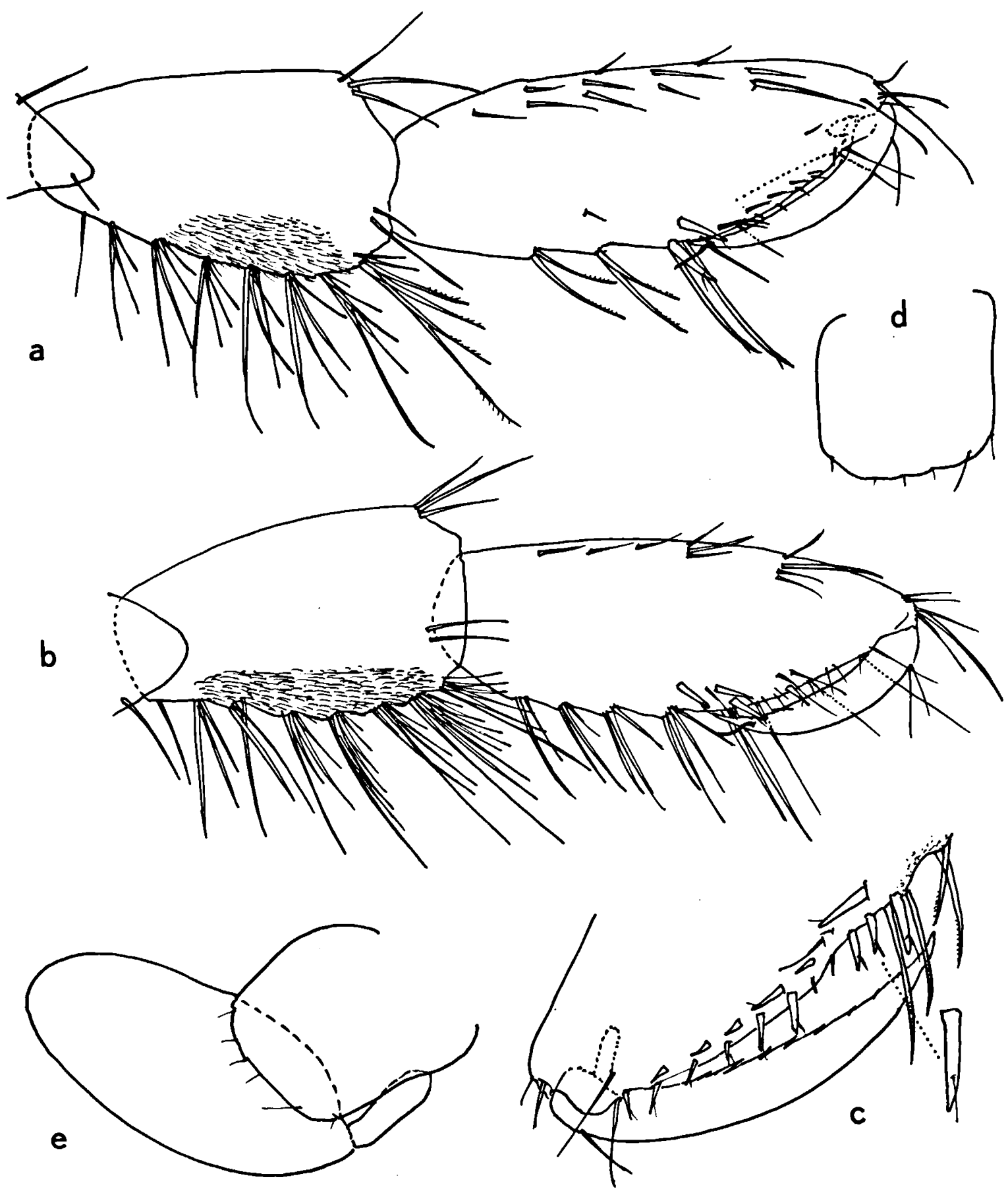

Fig. 25. Metaniphargus (Caribdzia) haitianus n. sp. (a, b, c, d: sta. 78-236; b: sta. 79-542): a, distal segments of second gnathopod, $Q$ (scale 3); b, same of ovigerous $\$$ (3); c, palma of second gnathopod, $\sigma$ (3); d, third coxal plate, $\$$ (2); e, fourth coxal plate and gill, $\&$ (2). Scales on fig. 11. 


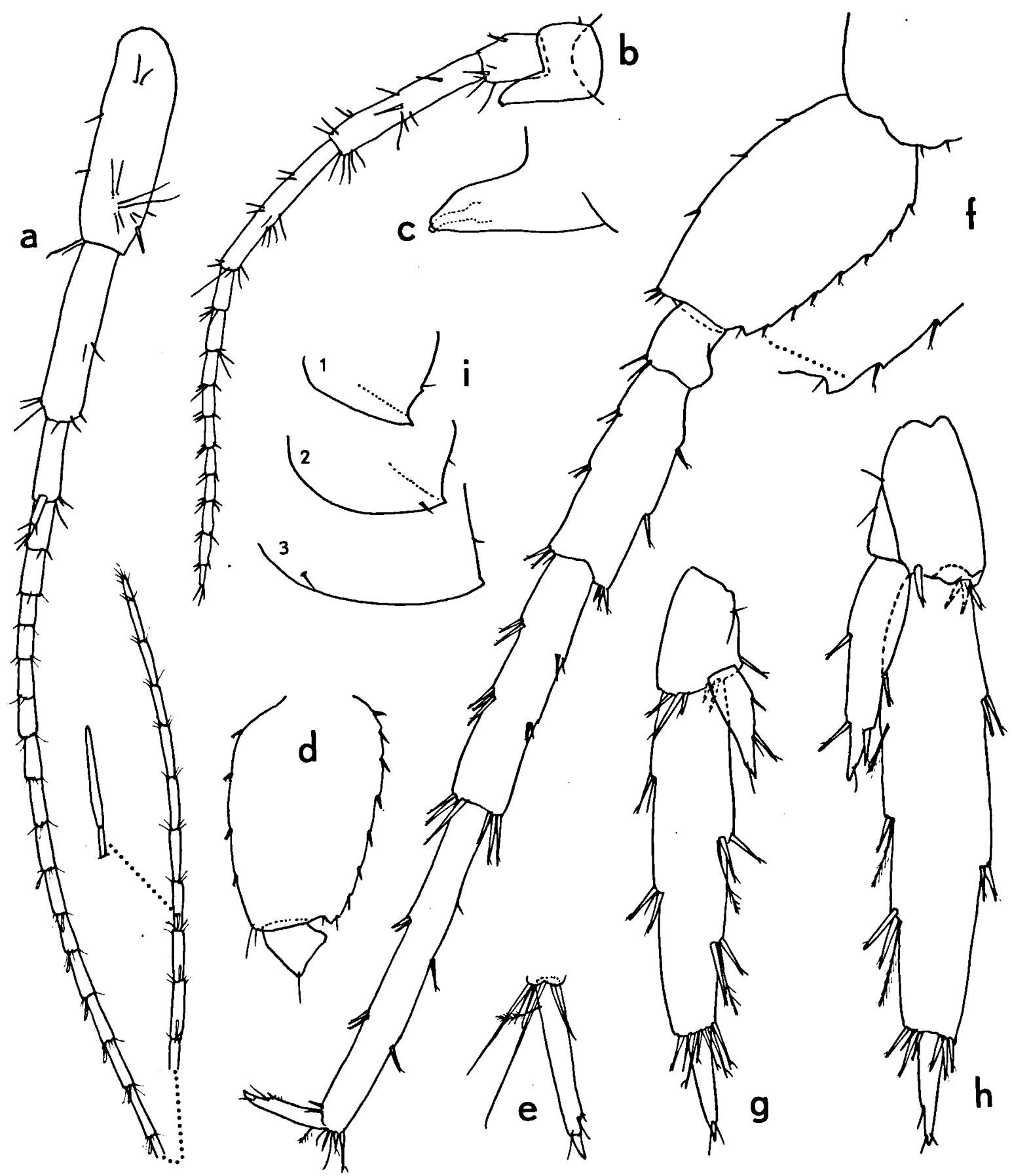

Fig. 26. Metaniphargus (Caribdzia) haitianus n. sp. (sta. 78-236): a, first antenna, $Q$ (scale 18); b, second antenna, $Q$ (18); c, gland cone of second antenna, $\sigma^{\circ}$; d, basal segments of fifth pereiopod, $Q$ (18); e, claw of fifth pereiopod, $\sigma^{\circ}(19) ; f$, seventh pereiopod, $Q$ (18); g, third uropod, $\sigma^{\circ}(16) ; \mathrm{h}$, third uropod, $\$$ (16); i, epimeral plates $1-3$, $\sigma^{\circ}(19)$. Scales on fig. 53 . 


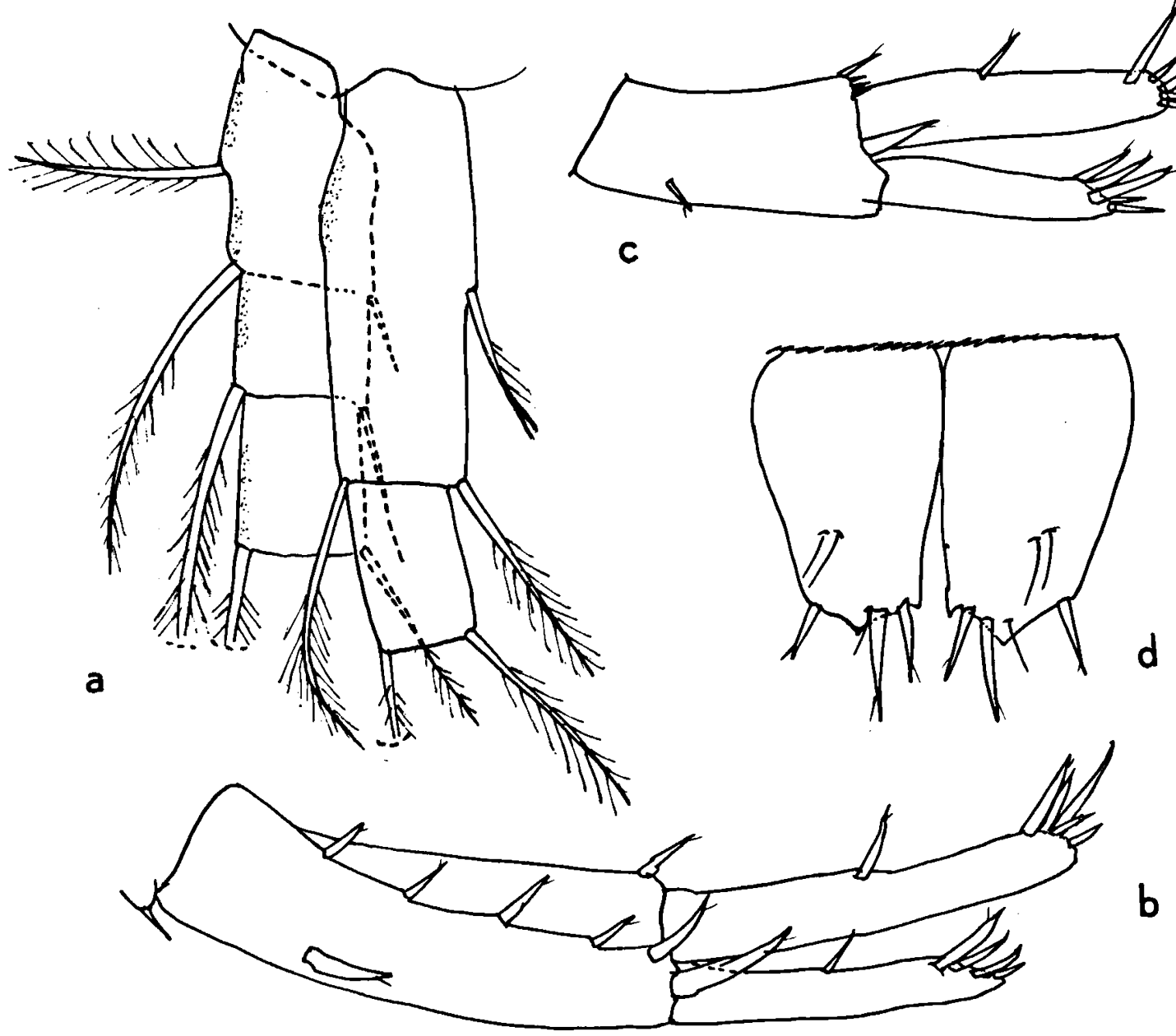

Fig. 27. Metaniphargus (Caribdzia) haitianus n. sp. (sta. 78-236): a, basal part of third pleopod, $\sigma^{\circ}$ (scale 4); b, first uropod $\uparrow(8) ; c$, second uropod, $९(8) ; \mathrm{d}$, telson, $\sigma^{\circ}(3)$. Scales on fig. 11.

Metaniphargus (Hispadzia) longipalpus n. sp. (Figs. 28-31)

Material. - One $\sigma^{\circ}$ (holotype), one $\$$ (allotype), nine paratypes. Amsterdam Expeditions to the West Indian Islands, sta. 79-659. Haiti, Dép. de la Grande Anse, one of the springs of the brook Tessier (in the valley of the river La Grande Anse, between Beaucalin and Ravine Blanche, at the foot of the Morne Castel) $\left(18^{\circ} 35^{\circ} 55^{\circ} \mathrm{N}\right.$ $74^{\circ} 10^{\prime} 46^{\circ} \mathrm{W}$ ); rheocrene spring with moderate water supply; pebbles, sand; chlorinity and temp. not determined; 5 Dec. 1979 (ZMA Amph. 107.840).

Description. - Body length ( $\left.0^{\circ}, \$\right)$ up to 4 $\mathrm{mm}$. Urosomites 1 and 2 each with 1 or 2 pairs of dorsal setules, urosomite 3 with a pair of dorsal spines.
Antenna 1 (fig. 28a) as long as the body. Peduncle segments 553, 523, and $280 \mu \mathrm{m}$, respectively. Flagellum very long, 47-segmented in the holotype, but the individual segments are less elongate than in $M$. crenatus $\mathrm{n}$. sp. (vide infra). Aesthetasks long ( $2 / 3$ of the corresponding segment), on segments 8 to 44. Accessory flagellum short, 2-segmented.

Antenna 2 (fig. 28b) similar to that of $M$. crenatus; flagellum 15-segmented.

Upper and lower lips as in $M$. curasavicus.

The mandibular palp (fig. 28c) has a relatively elongate 1st segment (3 times as long as wide); segments 1 and 2 are unarmed; segment 3 is extremely elongate, 1.75 times as long as 


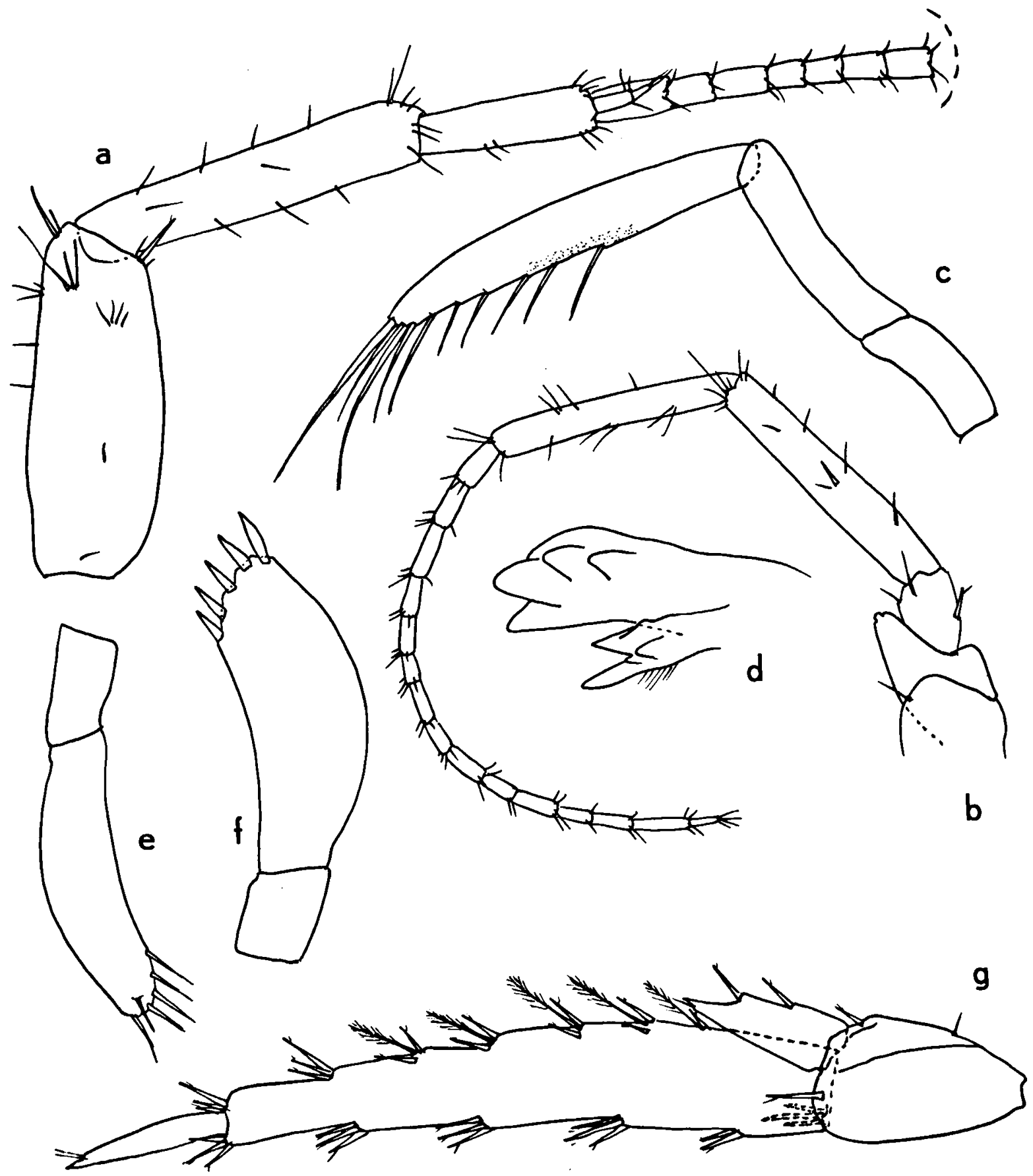

Fig. 28. Metaniphargus (Hispadzia) longipalpus n. sp. (ơ, sta. 79-659): a, first antenna (scale 2); b, second antenna (2); c, mandibular palp (3); d, pars incisiva of right mandible (4); e, palp of left first maxilla (3); f, palp of right first maxilla (3); $\mathrm{g}$, third uropod (2). Scales on fig. 11. 


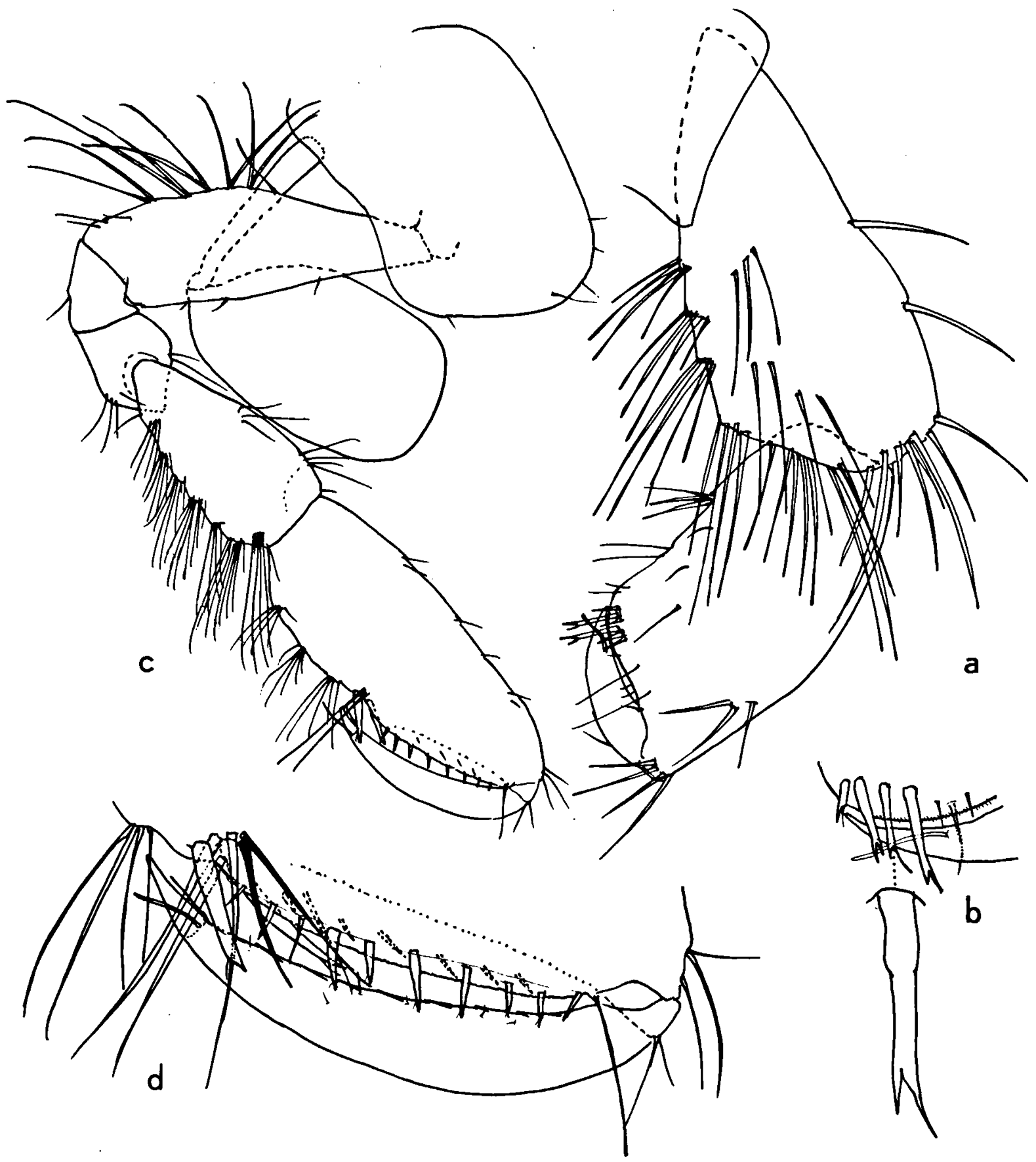

Fig. 29. Metaniphargus (Hispadzia) longipalpus n. sp. ( $\sigma^{*}$, sta. 79-659): a, distal segments of first gnathopod (scale 3); b palma of first gnathopod (9); c, second gnathopod (2); d, palma of second gnathopod (3). Scales on fig. 11. 


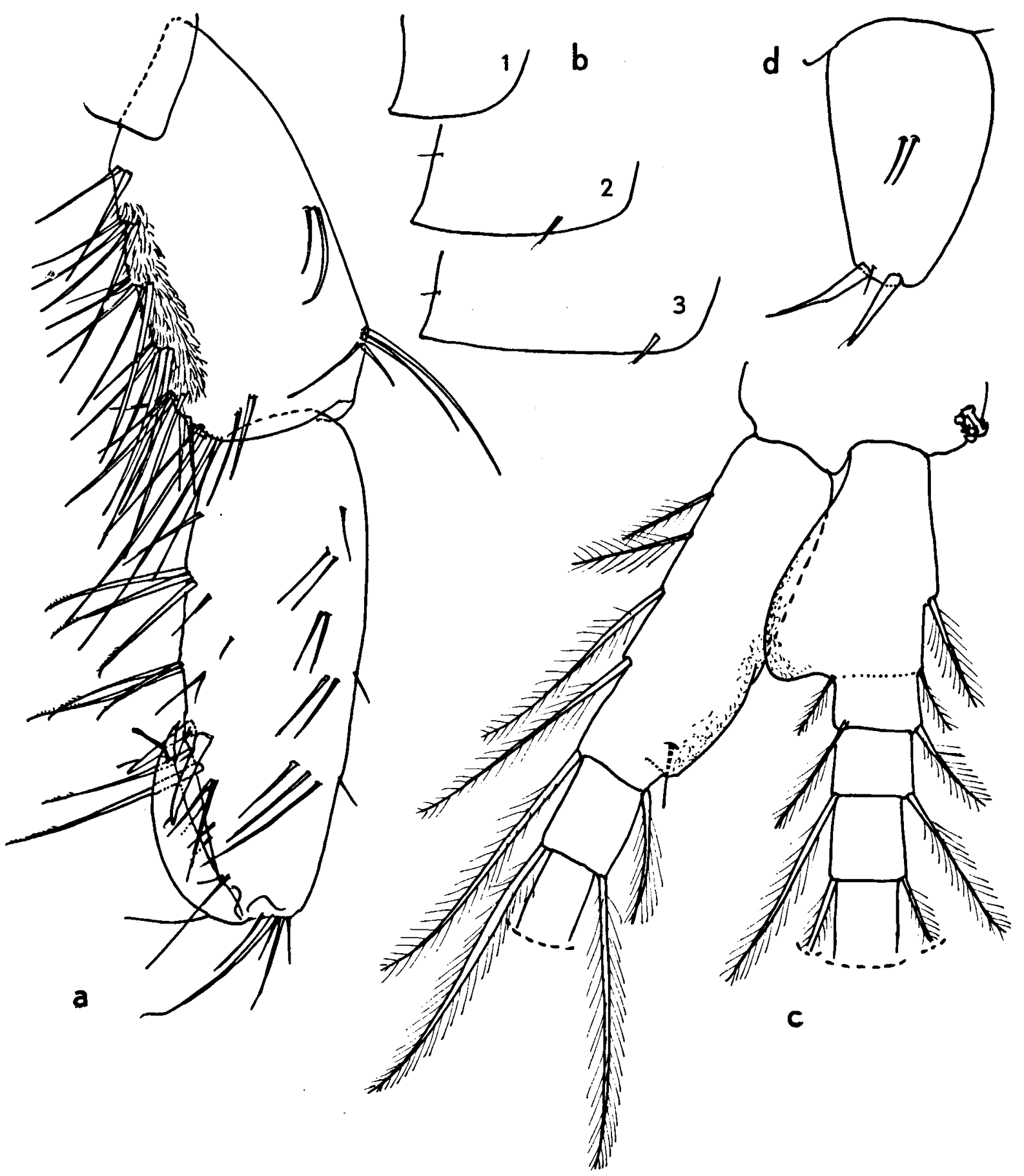

Fig. 30. Metaniphargus (Hispadzia) longipalpus n. sp. (sta. 79-659): a, distal segments of second gnathopod, 9 (scale 3); b, epimeral plates 1-3, $\sigma^{\circ}(7)$; c, basal part of third pleopod, $\sigma^{*}(3)$; d, telson lobe, $\sigma^{\circ}(3)$. Scales on fig. 11. 


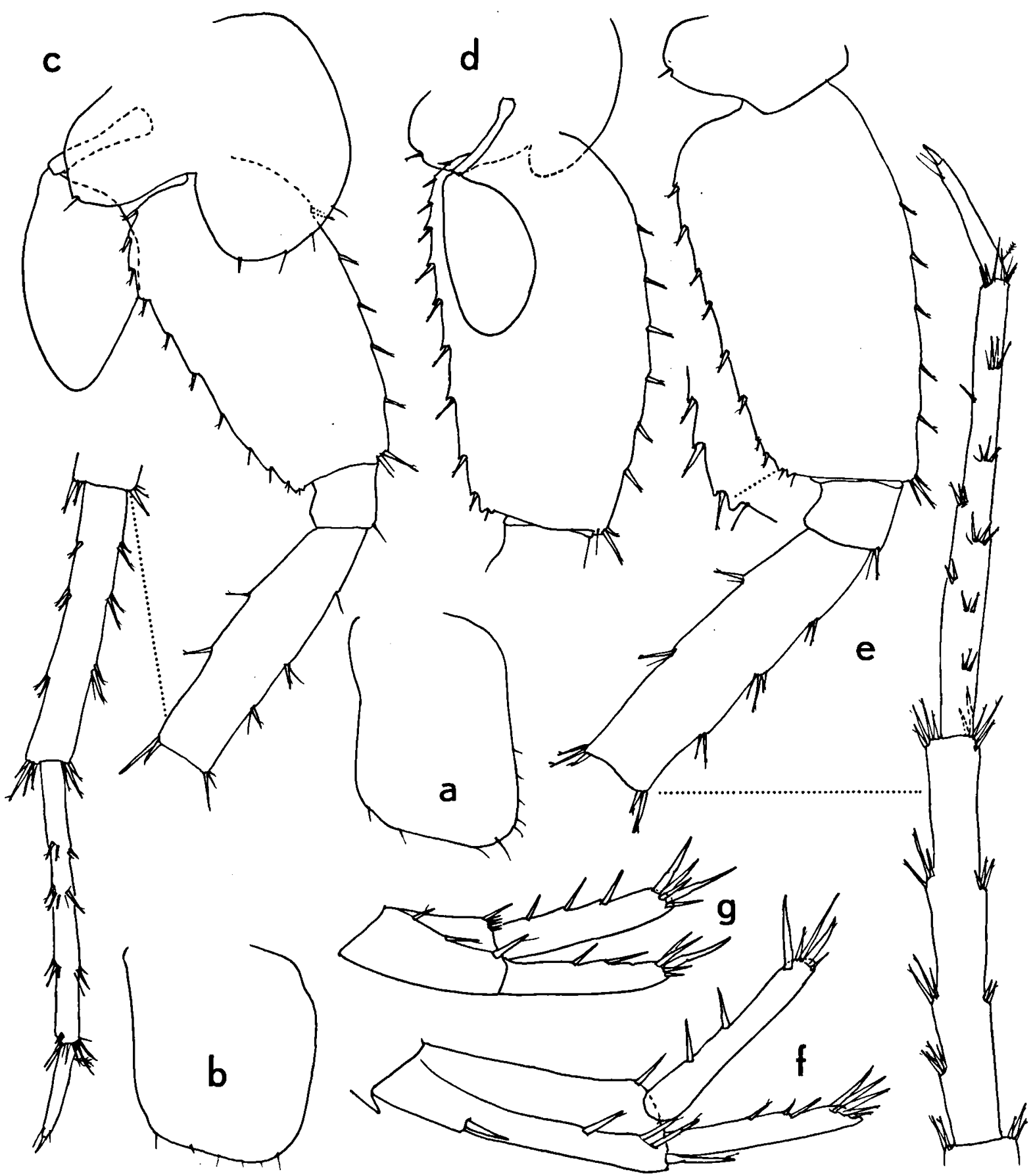

Fig. 31. Metaniphargus (Hispadzia) longipalpus n. sp. ( $\sigma^{\circ}$, sta. 79-659): a, first coxal plate (scale 18); b, fourth coxal plate (18); c, fifth pereiopod (18); d, basal segments of sixth pereiopod (18); e, seventh pereiopod (18); f, first uropod (18); $g$, second uropod (18). Scales on fig. 53. 
segment 2; its ventral margin is straight (not angular) and armed with 5 setae of more or less uniform size; (sub)distal armature consisting of 5 longer setae. The right lacinia mobilis (fig. 28d) is bifid (as usual in the genus), but the distal cusp is unarmed and the proximal cusp bears only 2 teeth and a row of setules.

Maxilla 1: Palps rather strongly asymmetrical (figs. 28e, f). Shape of the inner and outer lobes as in $M$. curasavicus; inner lobe with about 14 setae; outer lobe with 11 spines (inner denticles, from medial to lateral, 10, 7, 8, 6, 6, $4,6,5,1,1$, and 1 ).

Maxilla 2 and maxilliped similar to those of M. crenatus.

Gnathopod 1: Coxal plate (fig. 31a) without crenulations. Basis, ischium, and merus as in $M$. crenatus; carpus slightly longer than the propodus, posterior margin with 4 groups of setae; palmar angle spines very long and slender (figs. 29a, b).

Gnathopod 2 (fig. 29c): Coxal plate not crenulated. Carpus with 6 groups of setae on its posterior margin. Propodus elongate, posterior margin with 3 groups of setae; palmar angle with 2 very long spines $\left(\%, \sigma^{\circ}\right)$. Palmar margin of the male (fig. 29d) armed with 9 or 10 pairs of spines, that of the female (fig. 30a) with 2 pairs of setae. Claw of the male longer than that of the female.

Coxal gills on P2 through P6, characterized by their very thin, long stalk (figs. 29c, 31c, 31d).

Pereiopods 3 and 4 similar to those of $M$. palpator. Fourth coxal plate (fig. 31b) longer than wide.

Pereiopod 5 (fig. 31c): Basis with hardly produced posteroventral corner. Claw very slender.

Pereiopod 6 (fig. 31d) and pereiopod 7 (fig. 31e) with non-produced posteroventral corner of the basis; claw likewise slender.

Epimeral plates 1 and 2 slightly produced into a small point; plate 3 with an almost rectangular posteroventral corner (fig. 30b).

Pleopod 3 of the male transformed (fig. 30c): the basal endopodite segments are fused, bear setae of reduced length and are produced into a strong lateral lobe. The basal exopodite segments are also fused, their medial setation is reduced, but the medial margin is almost straight. No clothpeg spines.

Uropod 1 (fig. 31f): both exo- and endopodite with 2 or 3 dorsal spines. Uropod 2 (fig. $31 \mathrm{~g}$ ) as in $M$. crenatus.

Uropod 3 long (fig. 28g). Second exopodite segment much longer than the distal spines of segment 1. Endopodite pointed, just more than $1 / 4$ of the first exopodite segment.

Telson (fig. 30d): Lateral margin of each lobe regularly curved, inner margin straight. Distal armature consisting of 1 or 2 spines; no medial or lateral armature. Sensorial setae implanted in the proximal half of the telson.

Remarks. - The enormous elongation of the 3rd mandibular palp segment is approached only by $M$. palpator Stock, 1977 a, known from the islands on the St. Martin bank. M. palpator has, however, non-lobate 3rd male pleopods (and belongs, therefore, to another subgenus, Caribdzia).

Other noteworthy characteristics of the present new species are the unarmed condition of the 1st and 2nd palp segments, the long spines on the palmar angle of the 1 st and 2nd gnathopods $\left(\%, \sigma^{\circ}\right)$, the high number of flagellum segments, the short endopodite of the 3rd uropod, and the low number of telson spines. The most remarkable feature is the armature of the right lacinia mobilis (one cusp unarmed, the other with only 2 teeth, the usual condition being both cusps finely denticulated).

Distribution. - Only known from a rheocrene spring in hydrographic basin $\mathrm{Z}$ (basin of la Grande Anse, cf. fig. 4), in the extreme west of Haiti's southern peninsula.

\section{Metaniphargus (Hispadzia) chaetodactylus} n. sp. (Figs. 32-34)

Material. - One $\sigma^{\circ}$ (holotype), three juvenile males (?), paratypes. Amsterdam Expeditions to the West Indian Islands, sta. 79-502. Haiti: Dép. du Sud, banks of the river l'Islet, near Cayes $\left(18^{\circ} 13^{\prime} 32^{\prime} \mathrm{N} 73^{\circ} 41^{\prime} 28^{\circ} \mathrm{W}\right)$; in river alluvia consisting of gravel and white sand, with 


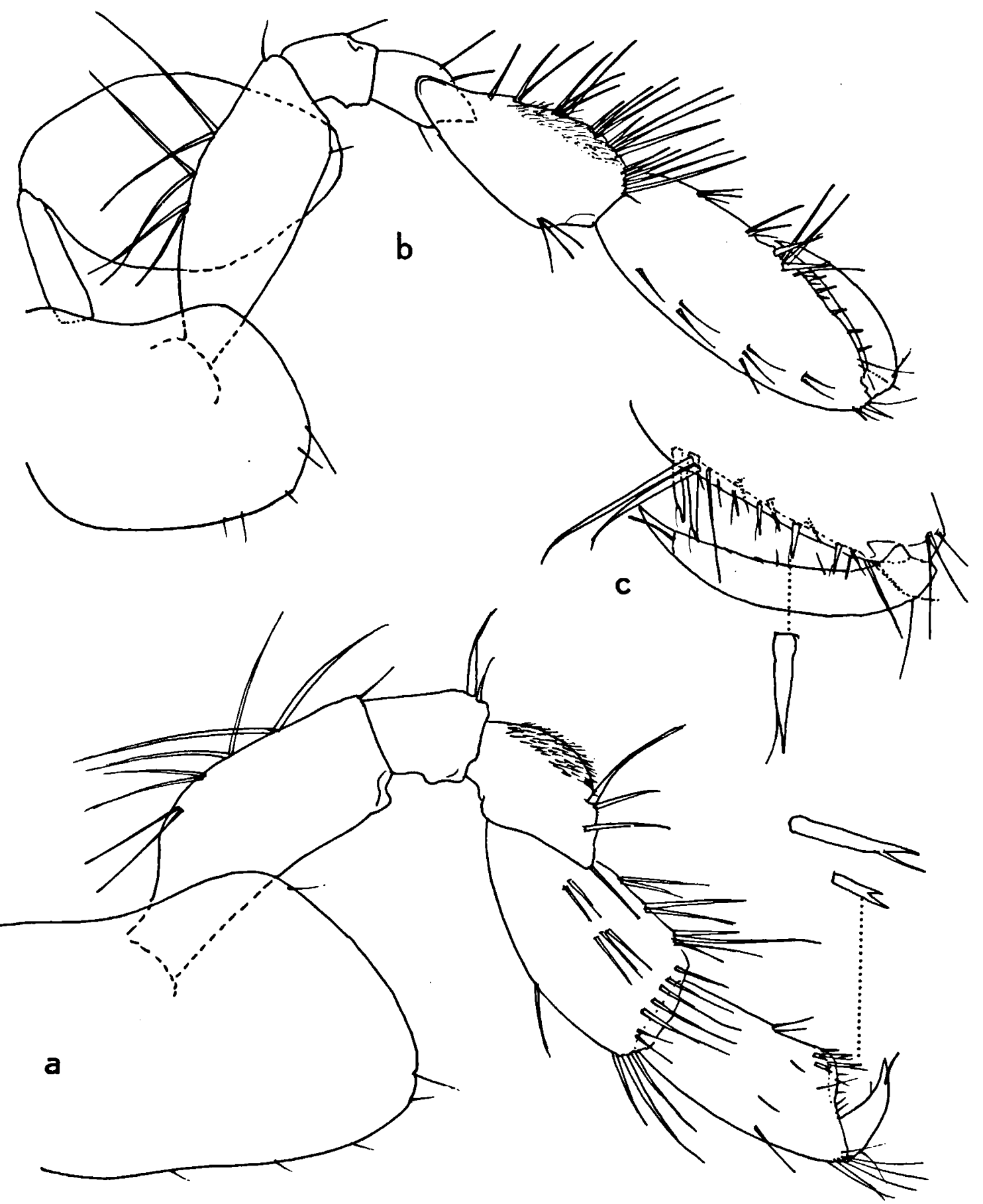

Fig. 32. Metaniphargus (Hispadzia) chaetodactylus n. sp. ( $\sigma^{*}$, sta. 79-502): a, first gnathopod (scale 3); b, second gnathopod (8); c, palma of second gnathopod (3). Scales on fig. 11. 
much plant debris (method Karaman-Chappuis); chlorinity and temp. not determined; 31 Oct. 1979 (ZMA Amph. 107.844).

Description. - Male, holotype (female unknown). Body length $3 \mathrm{~mm}$. Blind, unpigmented. Very similar to $M$. longipalpus (appendages not described in the sequel resemble those of that species).

Urosomites 1 and 2 without dorsal armature or with a pair of setules; urosomite 3 with a dorsal pair of spines.

Antenna 1: Length of peduncle segments 357,314 , and $174 \mu \mathrm{m}$, respectively. Number of flagellum segments unknown (more than 17-segmented, distal part broken off in all specimens).

Antenna 2: Gland cone robust, flagellum 10-segmented.

The lacinia mobilis of the right mandible is bifid and bears irregular teeth; the left lacinia bears 3 coarse teeth (figs. 33a, b).

Inner lobe of maxilla 1 with 11 setae; outer lobe with 11 spines, the inner margin of which is armed with $11,9,7,8,7,5,6,2,2,3$, and 2 denticles, respectively, from medial to lateral.

Gnathopod 1 as illustrated (fig. 32a).

Gnathopod 2 (fig. 32b): Posterior margin of carpus with 6 groups of setae, that of propodus with 2 groups. Palmar angle (fig. 32c) with 2 long spines; 3 pairs of hair-tipped spines on the palmar margin; the length of the latter spines is shorter than in $M$. longipalpus.

Coxal gills with less elongate stalk than in $M$. longipalpus (figs. 32b, 33c, 33e).

Coxal plate 4 as long as wide (fig. $34 a$ ).

Pereiopod 5 (fig. 33c): Basis with 5 spinules on the posterior margin. Number of spines on the long segments lower than in $M$. longipalpus. Claw very slender, outer margin with a pair of setae. Distal setae on propodus more than half as long as the claw (fig. 33d).

Pereiopod 6 (figs. 33e, f): Posterodistal corner of basis with 1 setule and 1 tooth-like process ( 2 processes in $M$. longipalpus); claw very long, outer margin with 2 groups of setae.

Pereiopod 7 (fig. 33g): Basis as in P6. Claw with 1 group of setae on outer margin.

Pleopod 3 (fig. 34b): Basal exopodite segments fused, setal length reduced, medial margin feebly curved, very slightly expanded distally. Basal endopodite segments also fused, likewise with setae of reduced length, without clothpeg spines; lateral margin with a regular lobe in the shape of an isosceles triangle.

Uropod 1 (fig. 34c): Distal spines of the rami very long. Pedunculus without middorsal spines.

Uropod 2 (fig. 34d): Pedunculus with distal row of 3 to 4 spinules, but without dorsal spines. Distal spines of the rami long.

Uropod 3 (fig. 34e): Inner ramus tapering, pointed, its length over $40 \%$ of the length of the first exopodite segment. Distal spines of first exopodite segment longer than in $M$. longipalpus.

Telson (fig. 34f): The two tapering lobes are unusually long for the genus Metaniphargus. Each lobe is armed with 2 distal, 1 lateral, and 1 medial spine.

Remarks. - The present species belongs clearly to the subgenus Hispadzia, by the structure of its right lacinia as well as by the lobation of the 3rd male pleopod. It is very similar to $M$. $(H$.) longipalpus (vide supra), also in other respects (the long spines on the palmar angle of gnathopods 1 and 2, the excessive elongation of the 3rd mandibular palp segment, etc.).

$M$. $(H$.$) chaetodactylus differs clearly from$ longipalpus in the following characters: (1) palmar margin of gnathopod 2 ( $\left.O^{*}\right)$ with only 3 pairs of spines; (2) coxal plate 4 as long as wide; (3) endopodite of uropod 3 relatively longer in relation to the length of the first exopodite segment; (4) telson lobes with medial and lateral armature; (5) slight differences in armature and shape of the posteroventral corner of the basis of pereiopods 5 to 7 ; (6) the claws of pereiopods 5 to 7 bear setae on their exterior margin; (7) the endopodal lobe on pleopod $3\left(O^{\prime}\right)$ is symmetrical (it has the shape of an isosceles triangle); (8) the stalk of the coxal gills is shorter.

Etymology. - From the Greek words $\chi \alpha i$ in ( = hair) and $\delta \dot{\alpha} x \tau u \lambda \circ \varsigma$ ( = finger), alluding to the setae on the outer margin of the finger of pereiopods 5 to 7 . 


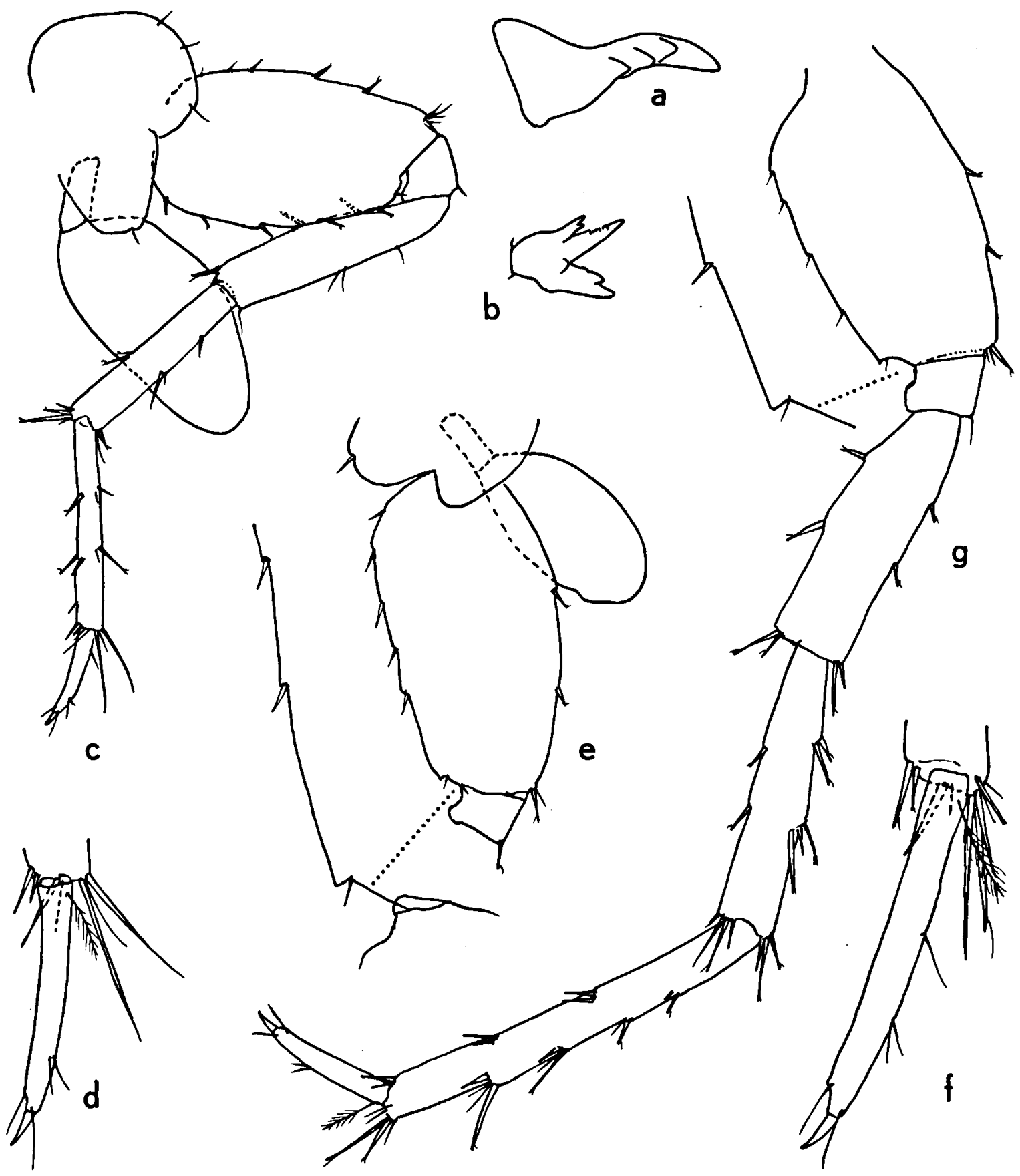

Fig. 33. Metaniphargus (Hispadzia) chaetodactylus n. sp. ( $\sigma$, sta. 79-502): a, left lacinia mobilis (scale 5); b, right lacinia mobilis (5); c, fifth pereiopod (2); d, claw of fifth pereiopod (3); e, basal segments of sixth pereiopod (2); $f$, claw of sixth pereiopod (3); g, seventh pereiopod (2). Scales on fig. 11. 

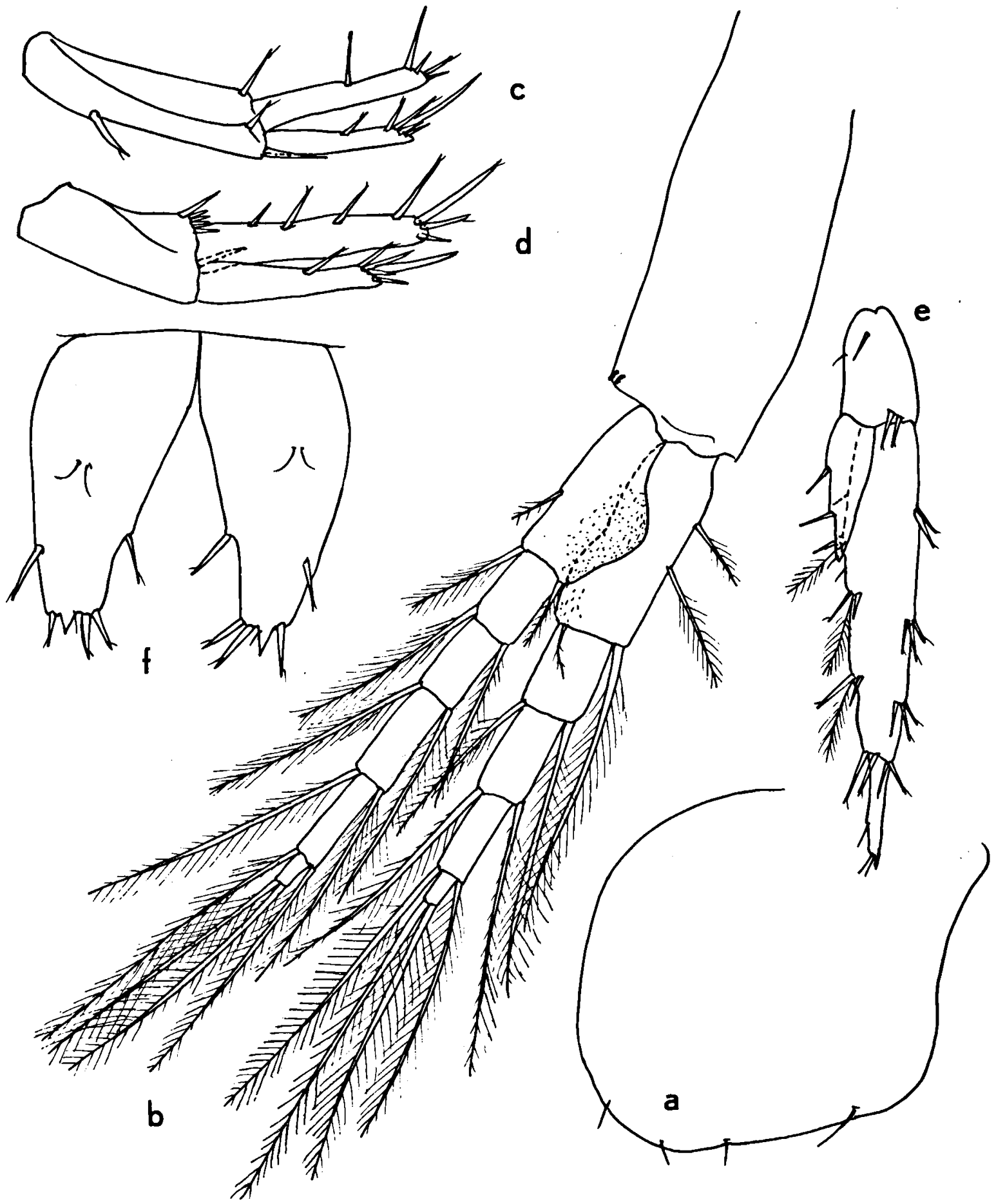

Fig. 34. Metaniphargus (Hispadzia) chaetodactylus n. sp. ( $\sigma^{\circ}$, sta. 79-502): a, fourth coxal plate (scale 2); b, third pleopod (3); c, first uropod (2); d, second uropod (8); e, third uropod (2); f, telson (3). Scales on fig. 11. 
Distribution. - Known from river alluvia in the Cayes region (hydrographic zone $\mathrm{X}$ in fig. $4)$, where it is more or less sympatric with $M$. pedunculatus.

\section{Metaniphargus (Hispadzia?) pedunculatus n. sp. (Figs. 35-38)}

Material. - One 9 (holotype). Amsterdam Expeditions to the West Indian Islands, sta. 79-508. Haiti: Dép. du Sud, large karst spring with many outlets on the road Cayes - Camp Perrin near the Bar de Simon $\left(18^{\circ} 14^{\prime} 44^{\prime} \mathrm{N} 73^{\circ} 45^{\prime} 52^{\prime} \mathrm{W}\right)$; sand, stones, waterweeds; chlorinity $25 \mathrm{mg} / \mathrm{l}$; temp. not recorded; 1 Nov. 1979 (ZMA Amph. 107.824).

Three $९$ ९ (fragmentary). Sta. 79-518. Dép. du Sud, river Grande Ravine du Sud, ca. $7 \mathrm{~km}$ upstream from the mouth $\left(18^{\circ} 13^{\prime} 29^{\prime} \mathrm{N} 73^{\circ} 46^{\prime} 23^{\prime} \mathrm{W}\right)$; small spring (or, more correctly, outlet of hyporheal) in alluvia of the river; sand, gravel, no vegetation; chlorinity $14 \mathrm{mg} / \mathrm{l}$; temp. $25.3^{\circ} \mathrm{C}$; 4 Nov. 1979 (ZMA Amph. 107.825).

Description of the holotype. - A large species (body length $6 \mathrm{~mm}$ ). Urosomite 1 unarmed, urosomite 2 with 2 pairs of dorsal spines, urosomite 3 with 1 pair of dorsal spines.

Antenna 1 (fig. 35a) $8 \mathrm{~mm}$ long; length of $1 \mathrm{st}$ to 3 rd peduncle segments 985,980 , and 620 $\mu \mathrm{m}$, respectively. Flagellum of 73 (!) segments; aesthetasks on segments 22 through 67; each aesthetask $2 / 3$ to $3 / 4$ of the length of the corresponding segment.

Antenna 2 (fig. 35b) with heavy gland cone. Flagellum 18-segmented.

Mandibular palp (fig. 35c) with short, unarmed first segment; second segment thin, with 1 distal seta; third segment narrow, 1.5 times as long as the second, distal half of its straight ventral margin armed with 7 setae of a size, distal end with 4 setae. Pars incisiva as illustrated (figs. 35d, e); right lacinia mobilis bifid, distal prong with 1 bicuspidate tooth, proximal prong irregularly toothed; left lacinia with 3 teeth on its proximal margin (figs. 35d, e).

Lower lip (fig. 35f) without trace of inner lobes.

Maxilla 1 (figs. 36a, b): Inner lobe with 12-20 plumose setae. Outer lobe with 11 spines, armed from lateral to medial with $1,1,0,2,3$,
$5,5,9,6,10$, and 17 medial teeth. Palps as illustrated.

Second maxilla similar to that of $M$. curasavicus.

Maxilliped as in $M$. nicholsoni.

Gnathopod 1 (fig. 36c): Carpus much longer than propodus; its posterior margin with 7 groups of setae. Palmar angle spines slender, bifid (fig. 36d).

Coxal gills (figs. 36e, 37b) with a very long, slender, narrow stalk, especially on the anterior legs.

Gnathopod 2 (figs, 36e, f): Carpus with 12 groups of setae on its posterior margin. Propodus very narrow and slender; posterior margin with 6 groups of setae; two long palmar angle spines.

Pereiopods 3 and 4 as in $M$. palpator. Coxal plate 4 (fig. $35 \mathrm{~g}$ ) longer than wide.

Pereiopod 5 (fig. 37a): Basis only 1.3 times as long as wide; posteroventral corner lobate. Merus, carpus and propodus short. Claw also short.

Pereiopods 6 (fig. 37b) and 7 (fig. 37c) likewise characterized by a short, broad basis, and short distal segments. Claw short.

Epimeral plates (fig. 38a) with an almost rectangular posterior corner; 2 nd and 3rd plates with a ventral spine; 2 nd plate without diagonal stripe.

Uropod 1 (fig. 38b): Rami armed with rather numerous, long spines.

Uropod 2 (fig. 37d): Peduncle with distal row of some 8 spinules. Rami with numerous, long spines.

Uropod 3 (fig. 38c): Inner ramus more than half as long as segment 1 of the outer ramus, pointed, armed with spines only. Outer ramus with spines on the lateral margin of segment 1 , spines + plumose setae on the medial margin; segment 2 narrow, longer than the spines on segment 1 .

Telson lobes (fig. 38d) short; each lobe with 1 lateral spine, and 3 to 5 distal spines; sensory setules implanted in the proximal half of the lobes.

Remarks. - The male of this species remained unknown. The morphological charac- 


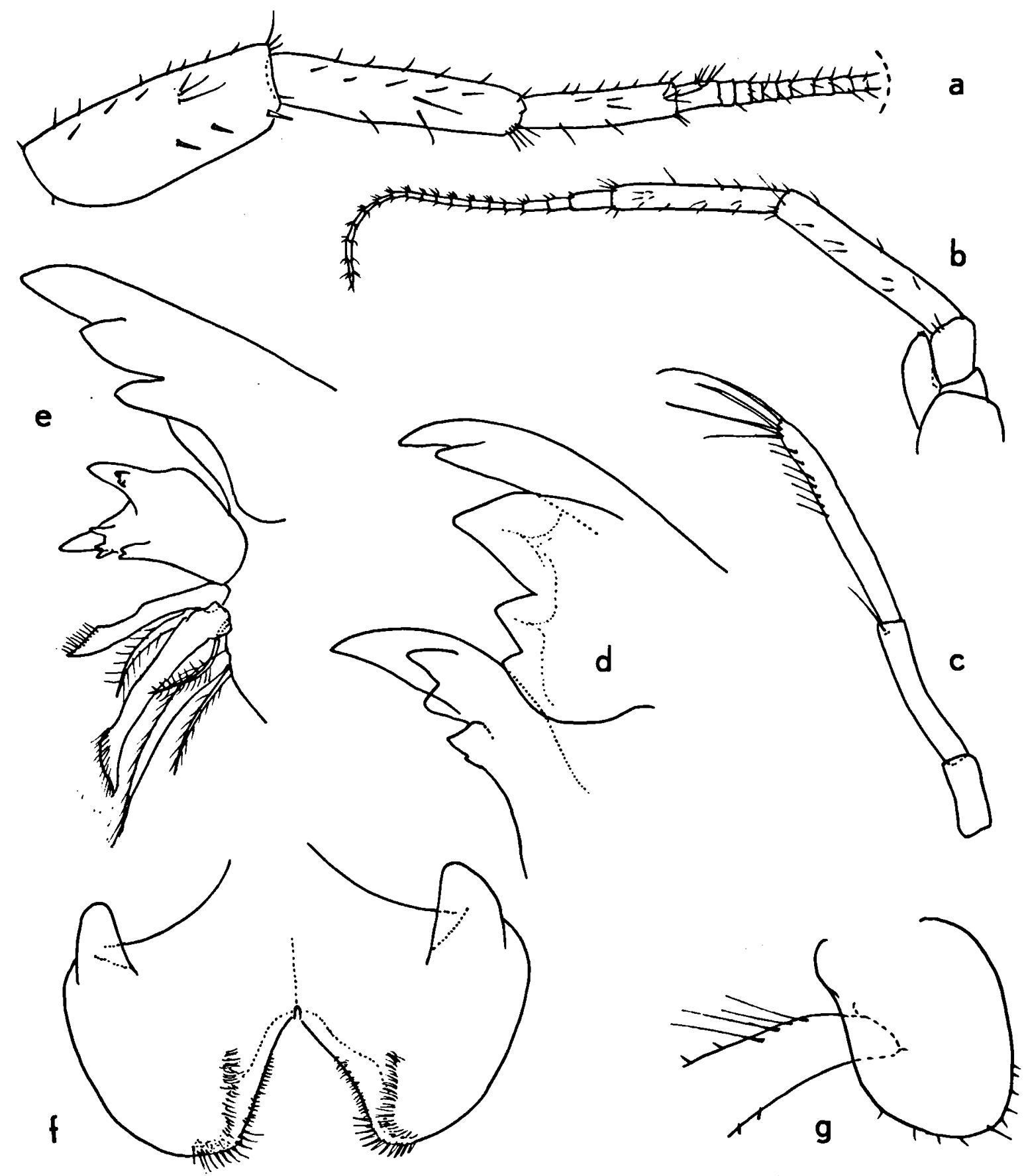

Fig. 35. Metaniphargus (Hispadzia?) pedunculatus n. sp. ( $\%$, sta. 79-508): a, first antenna (scale 1); b, second antenna (1); c, mandibular palp (2); d, pars incisiva of left mandible (4); e, same of right mandible (4); $f$, lower lip (2); $g$, fourth coxal plate (1). Scales on fig. 11. 


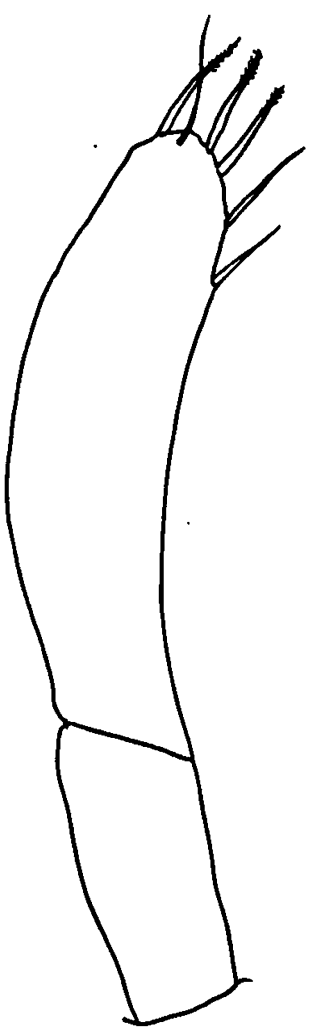

a

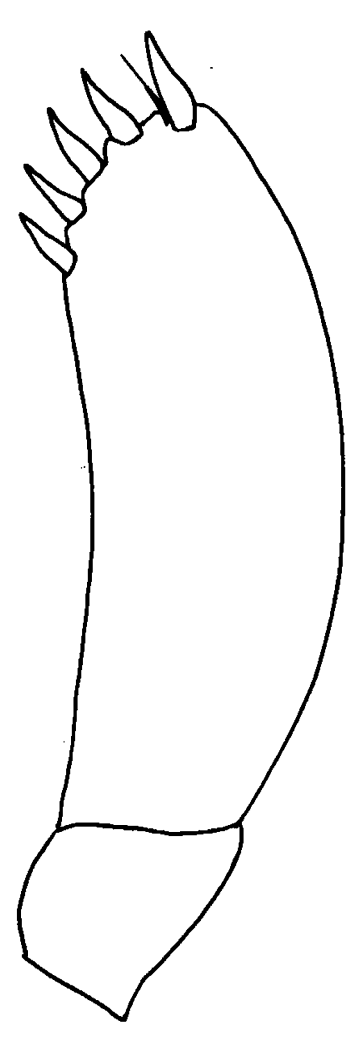

b
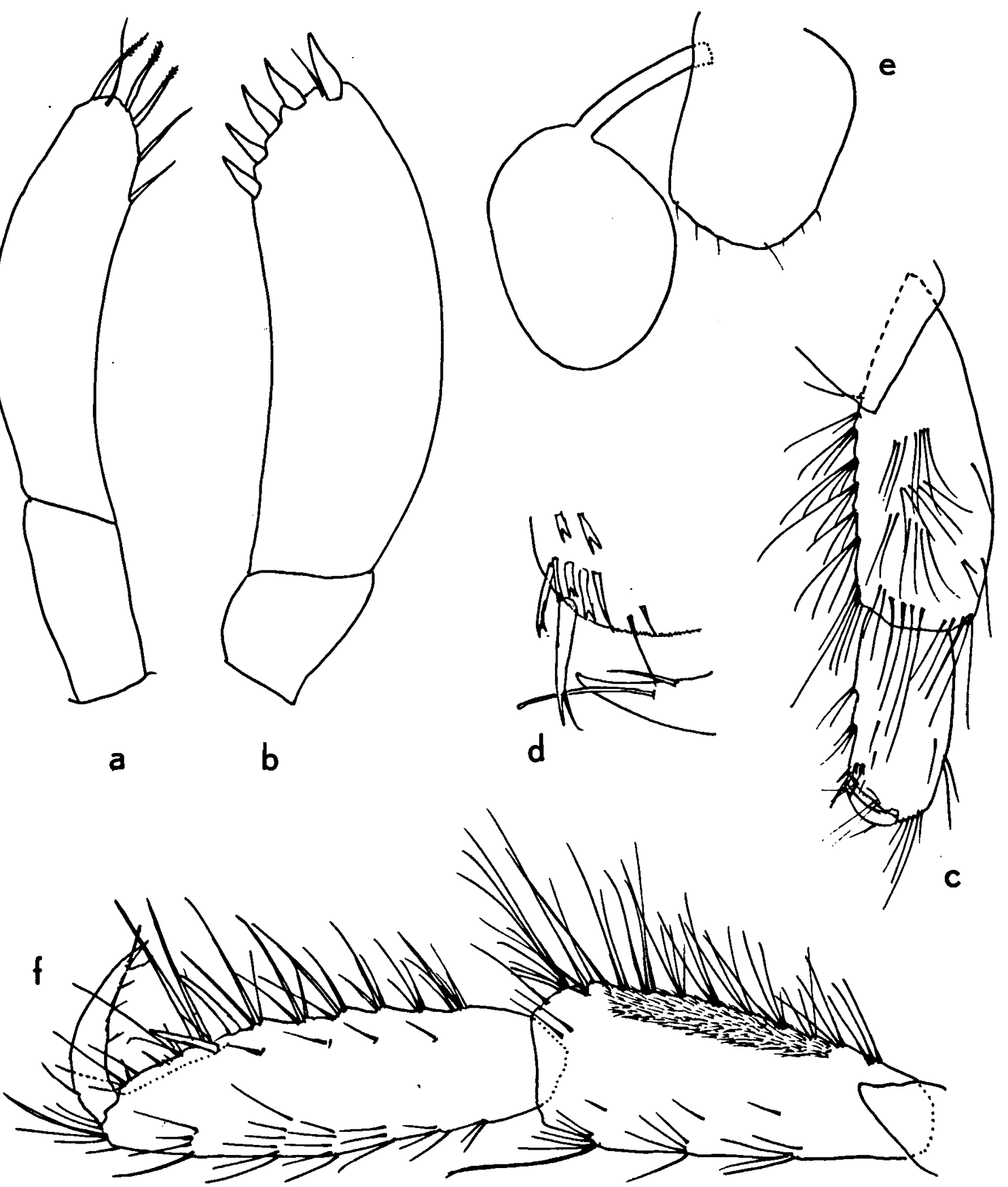

Fig. 36. Metaniphargus (Hispadzia?) pedunculatus n. sp. ( $\$$, sta. 79-508): a, palp of left first maxilla (scale 3); b, palp of right first maxilla (3); c, distal segments of first gnathopod (2); d, palma of first gnathopod (4); e, second coxal plate and gill (1); f, distal segments of second gnathopod (2). Scales on fig. 11. 


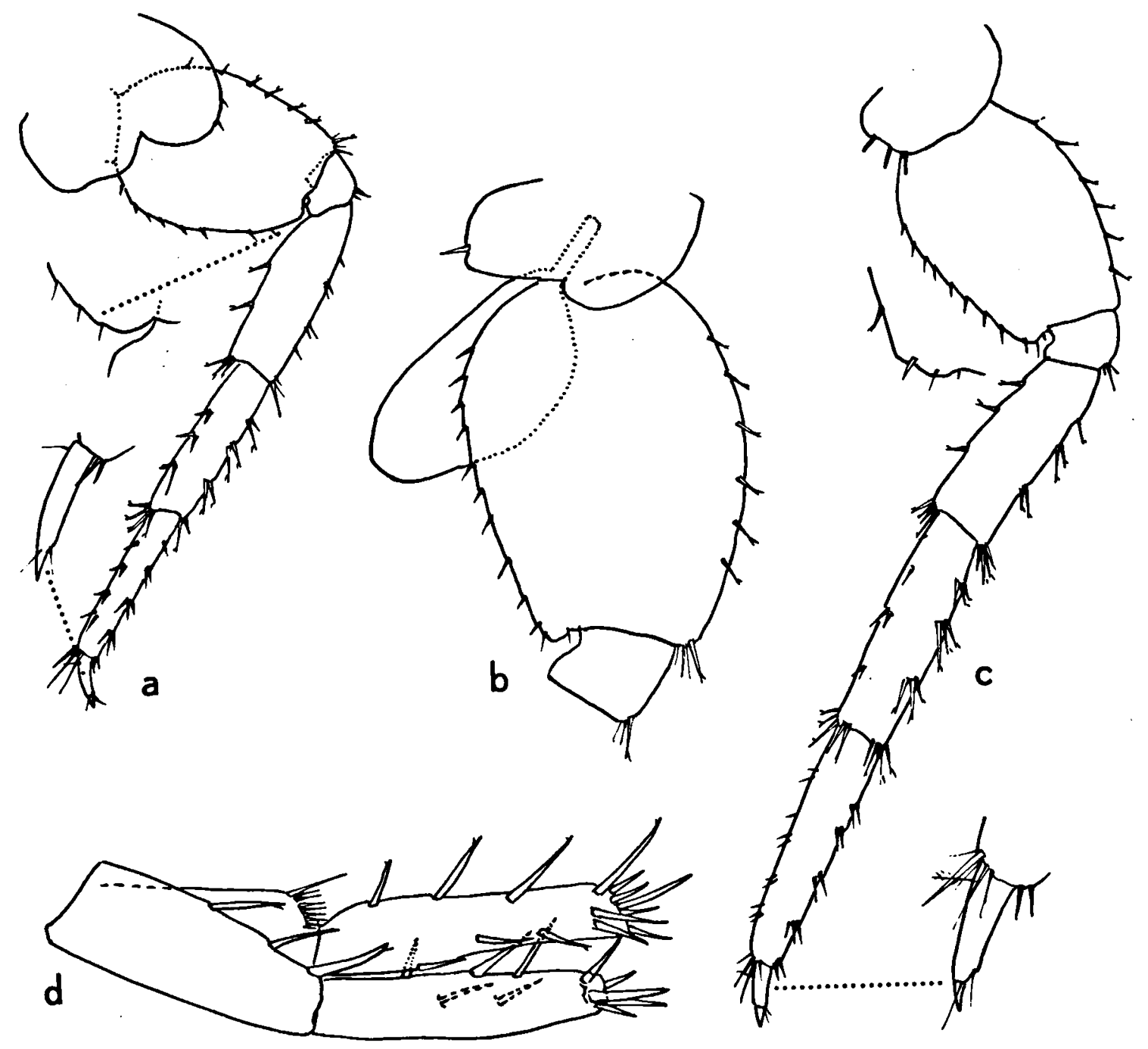

Fig. 37. Metaniphargus (Hispadzia?) pedunculatus n. sp. ( $९$, sta. 79-508): a, fifth pereiopod (scale 6); b, basal segments of sixth pereiopod (1); c, seventh pereiopod (6); d, second uropod (7). Scales on fig. 11.

ters of the female, however, show such close similarity to those of $M$. $(H$.$) longipalpus and (to$ a lesser degree) of $M$. $(H$.$) chaetodactylus, that we$ may safely assume that the present species belongs to the subgenus Hispadzia.

Points of resemblance to $M$. (H.) longipalpus are mainly the very long 3 rd mandibular palp segment with its straight ventral margin, the very long and thin stalk of the coxal gills, and the long palmar angle spines in gnathopods 1 and 2.

$M$. pedunculatus differs from $M$. longipalpus in (1) the high number of segments in the flagellum of A1; (2) in details of the armature of the mandibular palp (segment 2 with 1 seta, setae on segment 3 restricted to the distal half of the segment); (3) a higher number of telson spines; (4) a longer carpus in Gn. 1, armed with more numerous groups of setae on its posterior margin; (5) more numerous groups of setae on the carpus and propodus of $\mathrm{Gn} .2$; (6) the shortness of basis, merus, carpus, propodus, and claw in P5 to P7; (7) the much longer endopodite, and less elongate exopodite, in uropod 3.

$M$. chaetodactylus has an elongate 3rd man- 

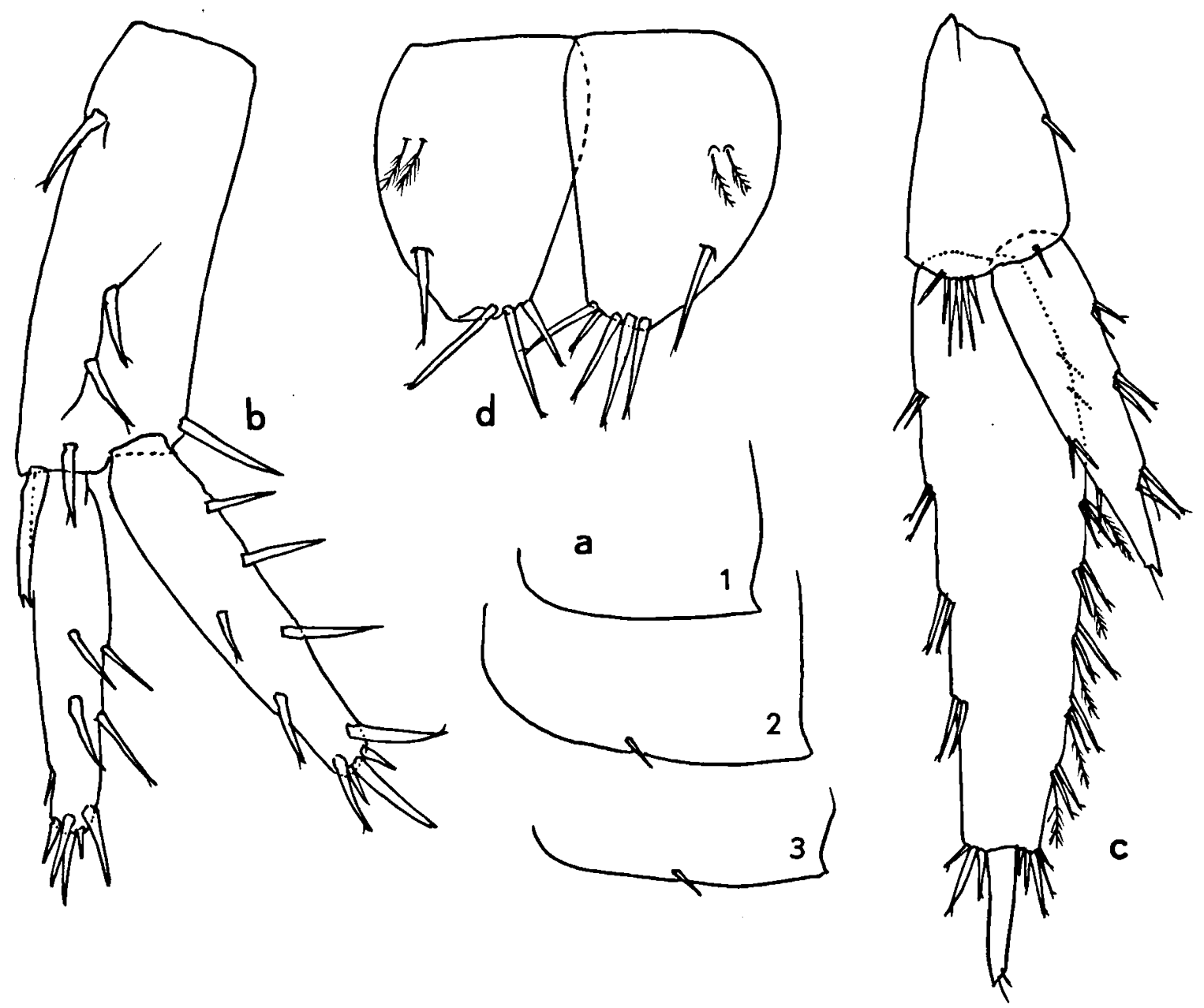

Fig. 38. Metaniphargus (Hispadzia?) pedunculatus n. sp. ( $९$, sta. 79-508): a, epimeral plates 1-3 (scale 7); b, first uropod (7) c, third uropod (7); d, telson (4). Scales on fig. 11.

dibular palp segment as well, but differs from the present species in characters 2, 4, 6, and 7 of the above list, and in a less spinose first uropod and shorter stalks in the coxal gills.

$M$. palpator from the St. Martin bank shares with $M$. pedunculatus the presence of armature on the 2nd mandibular palp segment, the very numerous articles in the flagellum of $A 1$, the great elongation of the carpus of Gn. 1, and of the propodus of $\mathrm{Gn}$. 2. $M$. pedunculatus can be distinguished by a longer first peduncle segment in $\mathrm{A} 1$, longer palmar angle spines in $\mathrm{Gn}$. 1 and Gn. 2, less slender P5 to P7, more spinose uropods 1 and 2, longer stalks in the coxal gills, etc.
The irregular armature of the lacinia mobilis of the right mandible is a particularity of $M$. pedunculatus. Usually, the two cusps of the lacinia are finely and regularly toothed in the genus Metaniphargus. In the subgenus Hispadzia exceptions occur, and the absence of a regularly toothed lacinia provides further evidence for the fact that the present species could belong in that subgenus. Final proof, of course, can only be obtained when the males become known.

The specimens from sta. 79-518 are fragmentary, but agree in all essential details with $M$. pedunculatus. These specimens have only 1 pair of spines on urosomite 2. 
Although all specimens are known from spring habitats, their large size and the very long first antennae seem to point to a cavernicolous rather than to a crenal or interstitial principal habitat for this species.

Distribution. - Known from two spring habitats near Cayes, both in hydrographic zone $\mathrm{X}$ (see fig. 4) of Haiti's southern peninsula.

Etymology. - The specific name, pedunculatus, refers to the long stalk of the coxal gills.

Metaniphargus (Haidzia) plumicauda n. sp. (Figs. 39-43)

Material. - One $\sigma$ (holotype), one $\&$ (allotype), one $\odot$ and six juveniles (paratypes). Amsterdam Expeditions to the West Indian Islands, sta. 79-556. Haiti: Dép. de l'Est, karst spring Ca-Auguste, not far from CayesJacmel, in the Cap Rouge zone near Diamant $\left(18^{\circ} 16^{\prime} 02^{\sim} \mathrm{N} 72^{\circ} 23^{\circ} 41^{\sim} \mathrm{W}\right)$; rather strong rheocrene; stones, gravel; chlorinity $14 \mathrm{mg} / 1$; temp. $22.5^{\circ} \mathrm{C}$; 15 Nov. 1979 (ZMA Amph. 107.841).

Description. - Body length of male $4 \mathrm{~mm}$, of female $5 \mathrm{~mm}$. Blind, unpigmented. Urosomite 1 with 1 pair of dorsal spines, urosomite 2 with 1 lateral spine on either side; urosomite 3 unarmed (fig. 43d).

Antenna 1 (fig. 39a) about $60 \%$ of the body length. Flagellum 27- to 33-segmented. Peduncle segment 1 with 2 ventral spines. Peduncle segment 2 hardly shorter than segment 1 (segment $1=464 \mu \mathrm{m}$, segment $2=436 \mu \mathrm{m}$, segment $3=222 \mu \mathrm{m}$, in the allotype). Accessory flagellum short, 2-segmented. Aesthetasks (in the holotype) from segment 4 to the penultimate segment of the flagellum, almost half as long as the corresponding flagellum segments.

Antenna 2 (fig. 39b): Gland cone heavy. Peduncle segment 4 with 3 spines. Flagellum 12-segmented.

Upper lip as in $M$. curasavicus. Lower lip as in $M$. pedunculatus.

Mandible: Right molar with a long seta (fig. 39c), left molar without seta. Left lacinia mobilis with 3 marginal teeth; between the lacinia and the molar, there is a row of 4 thin and 4 heavy plumose setae (fig. 39d). Right lacinia simple: 3-cuspidate, without marginal denticles (fig. 39f); between the lacinia and the molar 2 flat spines, 1 heavy and 3 thin setae. Molar flake present (left, right). Palp (figs. 39c, e): segment $3>2$; segments 1 and 2 unarmed; segment 3 with 4 " $E$ "'-setae; ventral margin with 1 to 3 long, widely spaced, " $D$ "-setae.

Maxilla 1: Inner lobe with 11-12 setae. Outer lobe with 11 distal spines, the medial ornamentation of which consists of $1,2,0,3,2,4,3,4$, 5,5 , and 9 denticles from lateral to medial. Palps asymmetrical: The right palp (fig. $39 \mathrm{~g}$ ) has a short basal segment and a widened distal segment, the latter with 4 spines +1 seta in the holotype (fig. $39 \mathrm{~g}$ ), but with 5 spines +1 seta in the female paratype (fig. 39i). The left palp (fig. 39h) has a longer basal segment and a slender distal segment, the latter with $3+1$ setae in the holotype (fig. $39 \mathrm{~h}$ ), but with $5+1$ setae in the female paratype (fig. 39j).

Maxilla 2 resembling that of $M$. curasavicus.

Maxilliped as in $M$. nicholsoni.

Gnathopod 1 (fig. 40a): Coxal plate longer than wide. Carpus longer than propodus, with 5 groups of setae on its posterior margin. Propodus squarish, palm slightly oblique. Palmar angle with only 3 slender spines (fig. $40 \mathrm{~b}$ ), bearing a subterminal setule, but being not typically bifid (fig. 40b, detail).

Gnathopod 2 (fig. 40c): Coxal gill large, broadly ovate, with a long, articulated stalk. Carpus rather elongate, with 7 posterior groups of setae. Propodus sexually dimorphous: In the male, the palma is long and the posterior propodal margin bears 2 groups of setae (fig. 40c); the male has 2 slender palmar margin spines, and 1 spine opposing the tip of the dactylus, implanted far proximad; palmar margin with 4 pairs of spines, which are about half as long as the palmar angle spines (fig. 40d). In the female (fig. 41a), the carpus is slightly longer in comparison with the length of the propodus; the carpus bears 8 groups of setae on its posterior margin; the palma is short; the free posterior margin of the propodus bears 4 groups of setae; the proximal, isolated spine (found also in the male) does not oppose the tip of the dactylus; the palmar angle bears 2 long spines, the 


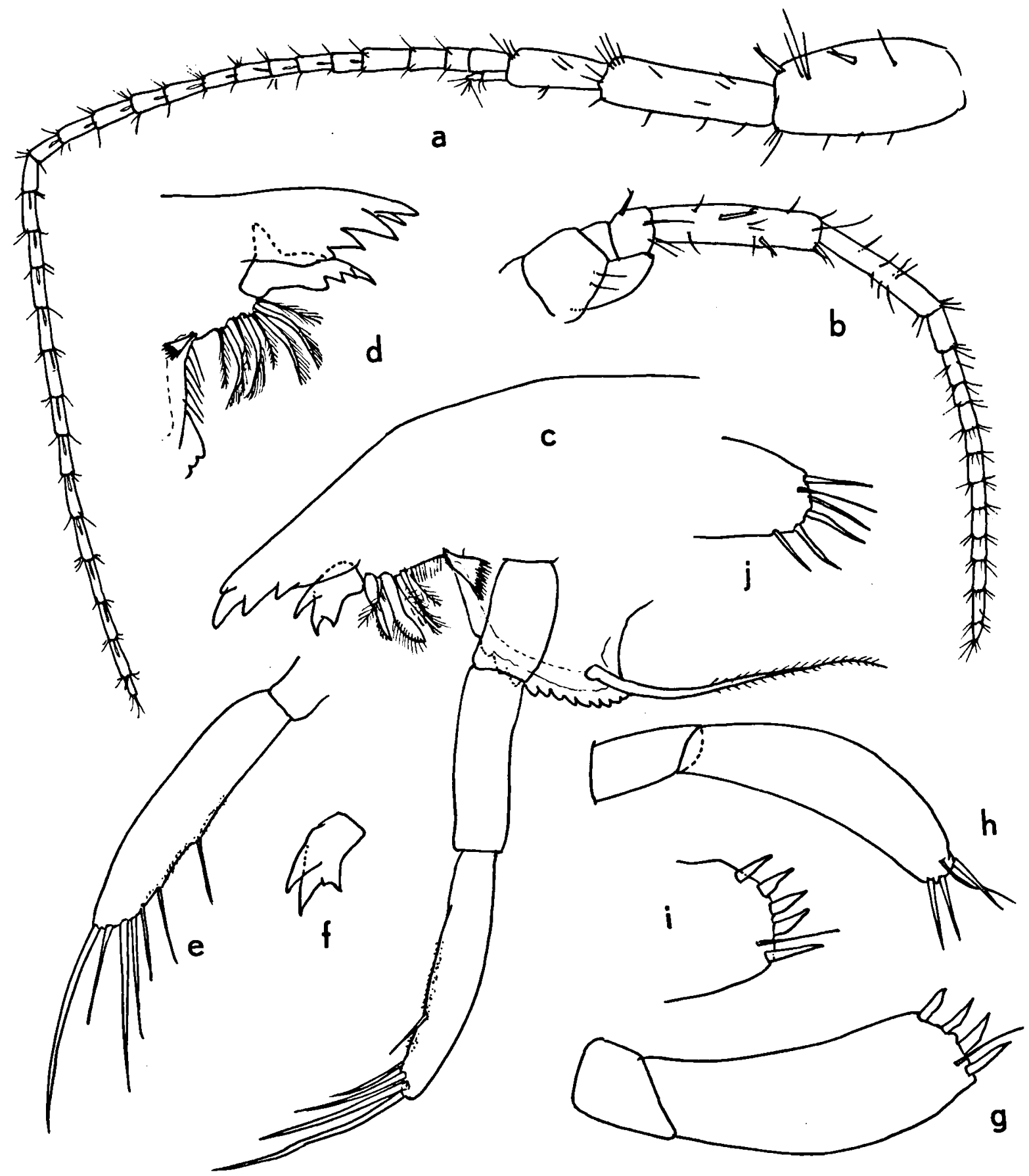

Fig. 39. Metaniphargus (Haidzia) plumicauda n. sp. (sta. 79-556): a, first antenna, $\sigma^{\circ}$ (scale 7); b, second antenna, $\sigma^{\prime \prime}$ (7); c, right mandible, $\$$ (3); d, pars incisiva of left mandible, $\sigma^{\circ}(3)$; e, distal mandibular palp segment, $\$$ (3); f, right lacinia mobilis, $\$$ (3); g, palp of right first maxilla, o holotype (9); h, palp of left first maxilla, ơ holotype (9); i, tip of palp of right first maxilla, $९$ paratype (3); j, tip of palp of left first maxilla, $\&$ paratype (3). Scales on fig. 11. 


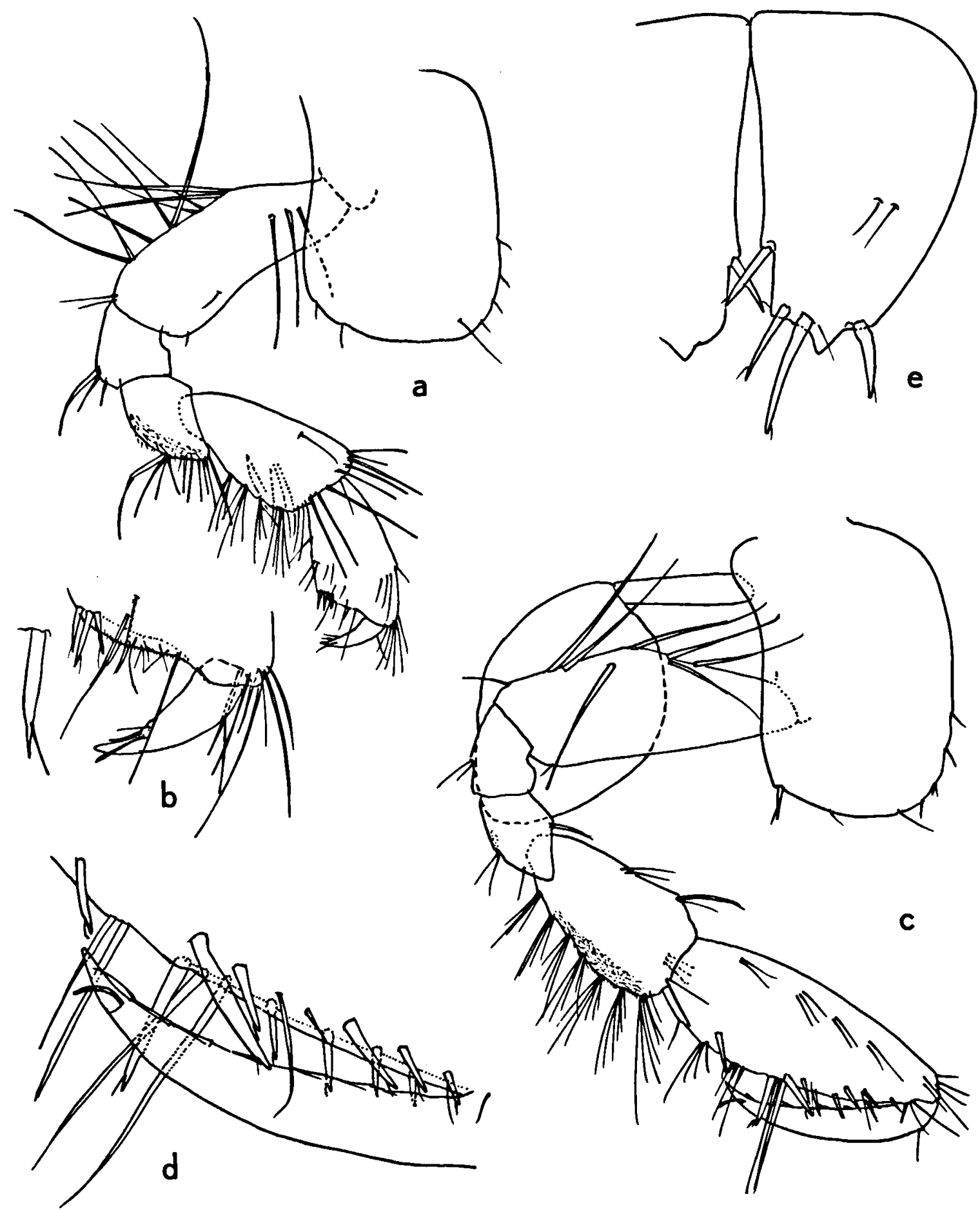

Fig. 40. Metaniphargus (Haidzia) plumicauda n. sp. ( $\sigma^{*}$, sta. 79-556): a, first gnathopod (scale 2); b, palma of first gnathopod (3); c, second gnathopod (2); d, palma of second gnathopod (3); e, telson (3). Scales on fig. 11. 


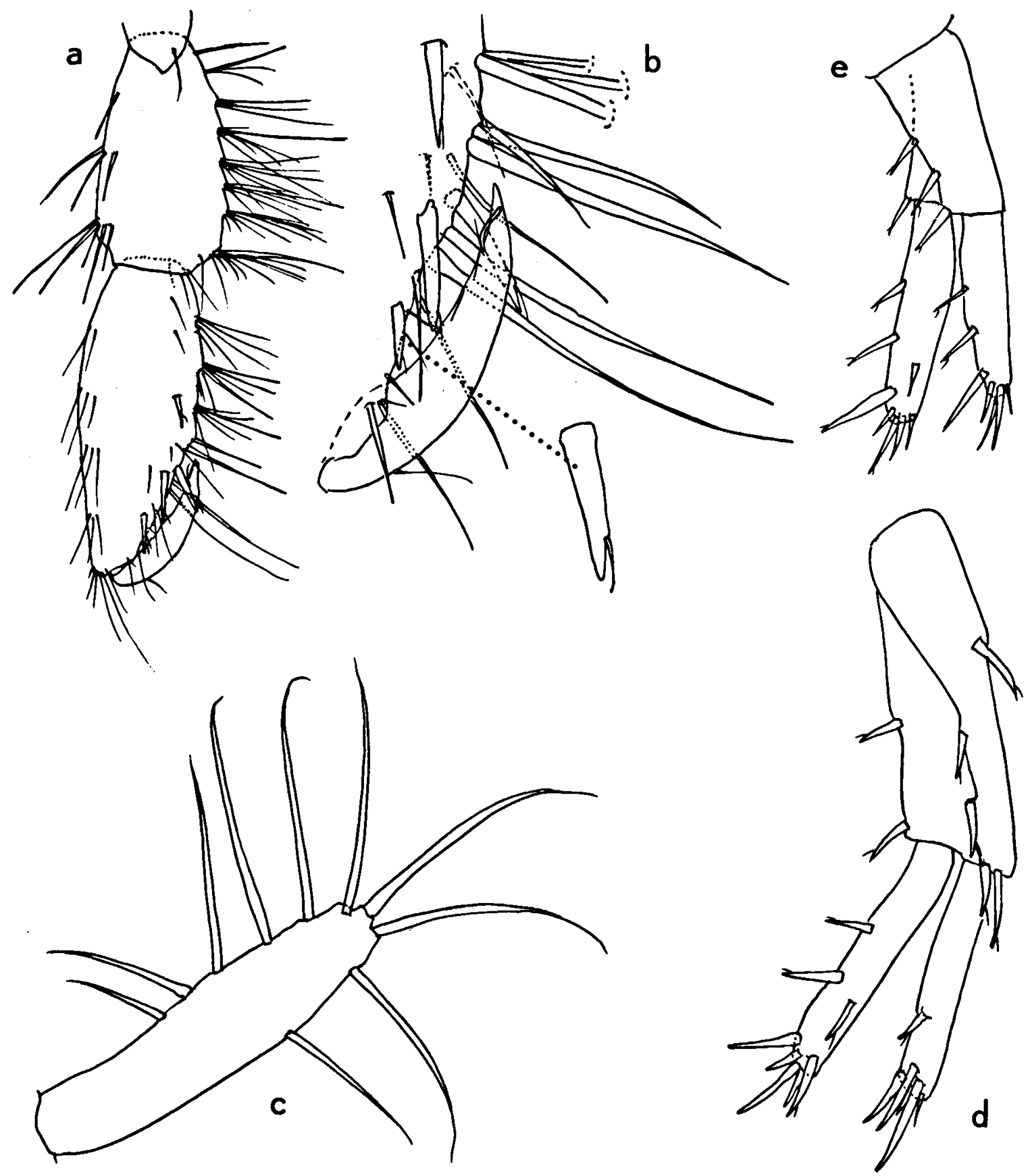

Fig. 41. Metaniphargus (Haidzia) plumicauda n. sp. (sta. 79-556): a, distal segments of second gnathopod, $९$ (scale 2); b, palma of second gnathopod, $९$ (3); c, oostegite of second gnathopod, $९$ (3); d, first uropod, $\sigma^{\circ}$ (2); e, second uropod, $\sigma^{\circ}$ (2). Scales on fig. 11. 


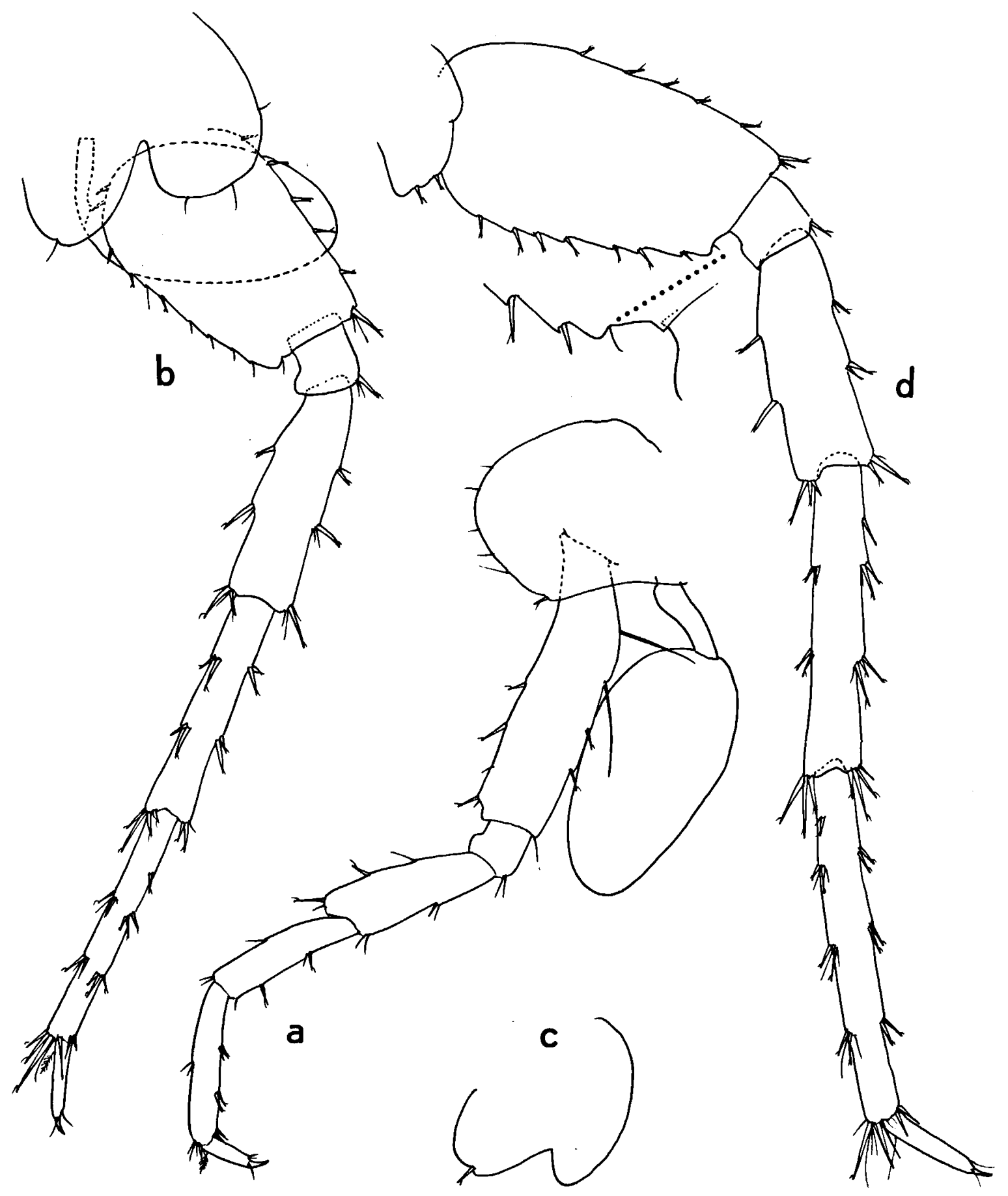

Fig. 42. Metaniphargus (Haidzia) plumicauda n. sp. ( $0^{\circ}$, sta. 79-556): a, fourth pereiopod (scale 18); b, fifth pereiopod (18); c, sixth coxal plate, from the right (18); d, seventh pereiopod (18). Scales on fig. 53. 


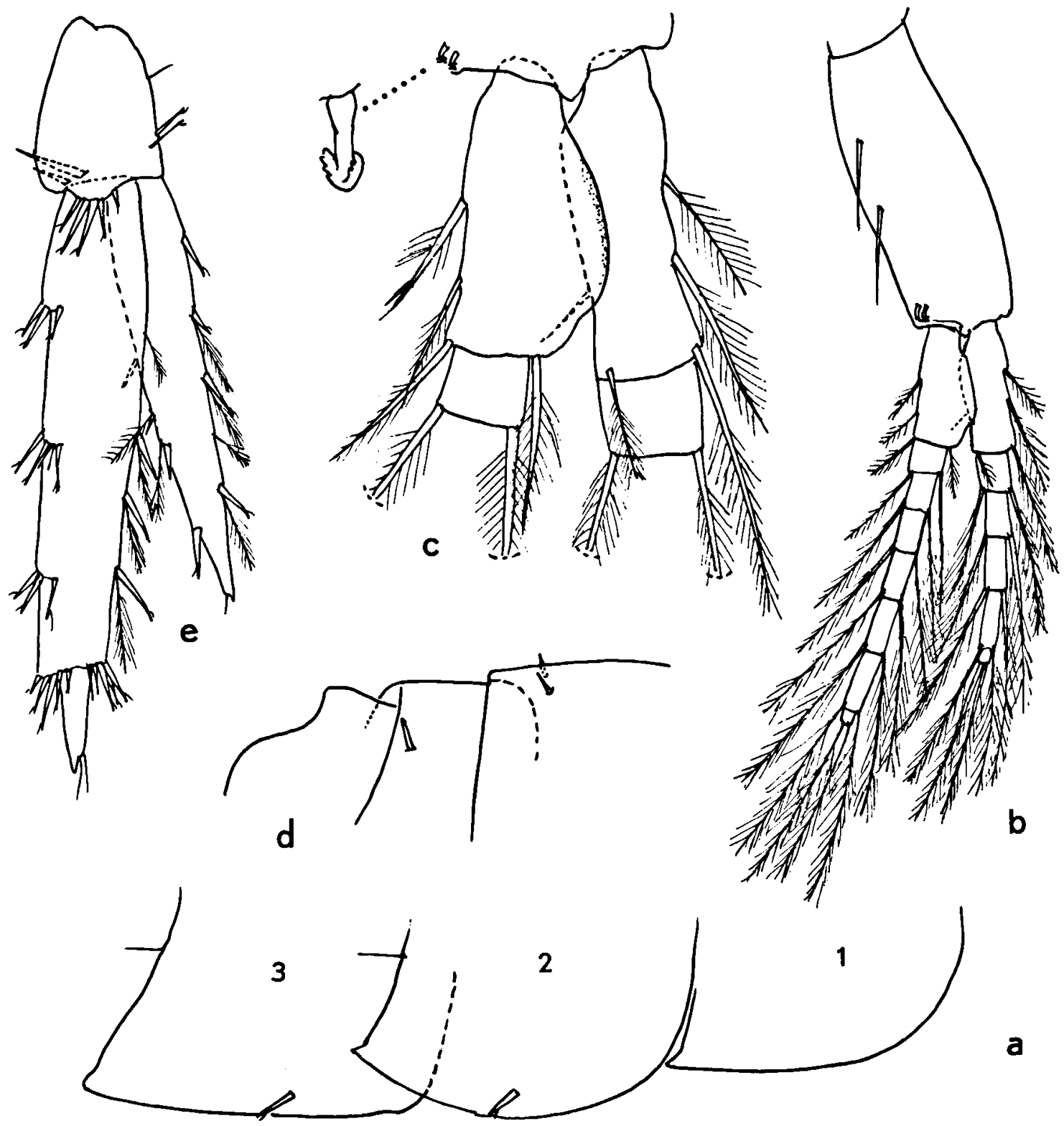

Fig. 43. Metaniphargus (Haidzia) plumicauda n. sp. (sta. 79-556): a, epimeral plates 1-3, $\sigma^{\circ}$ (scale 2); b, third pleopod, o (2); c, same, detail (3); d, urosomites 1-3, from the right, $९$ (2); e, third uropod, o (2). Scales on fig. 11.

palmar margin bears several long setae and 1 mid-palmar spine (fig. $41 \mathrm{~b}$ ).

Oostegites on P2 to P5, linear (fig. 41c).

Coxal gills also on P2 to P5 (!).

Pereiopod 3 similar to P4 (fig. 42a); fourth coxal plate not emarginate.

Pereiopod 5 (fig. 42b) shorter than P6. Coxal plate strongly lobate, lobes equal in length; basis with a small, not overhanging, posterodistal lobe.

Pereiopod 6 hardly shorter than P7. Coxal plate postero-lobate (fig. 42c).

Pereiopod 7 (fig. 42d): Coxal plate indistinctly lobate, but of the postero-lobate type; basis slightly lobate, but not overhanging.

Epimeral plates (fig. 43a) ending in a small 
acumination. Plate 1 unarmed, plates 2 and 3 with 1 ventral spine; no diagonal stripe on plate 2.

Medioproximal margin of endopodite of pleopods 1 to 3 with 1 clothpeg spine each (fig. 43c).

Pleopod 3 sexually dimorphic. In the male (fig. 43b), the basal (fused) endopodite segments bear a lateral expansion, vaguely bilobate (fig. 43c). On the pedunculus there are two retinacula, anchor-shaped, with 3 teeth on each arm of the anchor (fig. 43c).

Uropod 1 (fig. 41d) with proximoventral spine. Rami with strong dorsal and terminal spines.

Uropod 2 (fig. 41e): Peduncle without distal row of spinules.

Uropod 3 (fig. 43e): Length of the inner ramus about $90 \%$ of that of segment 1 of the outer ramus. Both rami with spines and plumose setae. Second exopodite segment rather short, but distinctly longer than the distal spines of segment 1 .

Telson completely cleft (fig. 40e); three distal spines and 1 medio-subdistal spine; sensory setae slightly beyond the middle of the telsonic lobes.

Etymology. - The specific name, plumicauda (from the Latin words pluma $=$ feather, and cauda $=$ tail) alludes to the plumose setae on exoand endopodite of uropod 3.

Remarks. - By the combination of a long endopodite, provided with plumose setae, of uropod 3 and a transformed male pleopod 3, the subgenus Haidzia and its only species, $H$. plumicauda, differ from all other taxa within the genus Metaniphargus. The absence of a coxal gill on $\mathrm{P} 6$ is autapomorphous.

Distribution. - Known from a single locality, a freshwater karst spring in hydrographic zone $\mathrm{O}$ (cf. fig. 3) near Cayes-Jacmel.

\section{Metaniphargus (Guadzia) crenatus n. sp. (Figs. 44-47)}

Material. - One $\sigma^{\circ}$ (holotype), one $\odot$ (allotype), one ᄋ, one juv. (paratypes). Amsterdam Expeditions to the West Indian Islands, sta. 79-640. Haiti: Dép. de la
Grande Anse, Bac well, near Jérémie (near Hôtel Versailles) $\left(18^{\circ} 38^{\circ} 06^{\sim} \mathrm{N} 74^{\circ} 06^{\prime} 48^{\wedge} \mathrm{W}\right)$; covered well, very clean, loamy, with pump, situated ca. $150 \mathrm{~m}$ from the sea, at the foot of a chalk cliff; water level at $3 \mathrm{~m}$, water depth 2 m; chlorinity $445 \mathrm{mg} / \mathrm{l}$; temp. $27.5^{\circ} \mathrm{C}$; 1 Dec. 1979 (ZMA Amph. 107.826).

Six \& \&. Sta. 79-639. Dép. de la Granse Anse, Jérémie, Berguer well, rue Paul Emile Jeanmichel, ca. 100 $m$ from the sea $\left(18^{\circ} 38^{\prime} 32^{\sim} \mathrm{N} 74^{\circ} 07^{\circ} 05^{\sim} \mathrm{W}\right)$; open well, clean; water level at $4 \mathrm{~m}$, water depth $0.8 \mathrm{~m}$; chlorinity 131 mg/l; temp. $26.2^{\circ}$ C; 1 Dec. 1979 (ZMA Amph. 107.827).

Description. - Body length 3.5-4 mm. Urosomites 1 and 2 with 2 pairs of dorsal spines.

Antenna 1 (fig. 45b) very slender, slightly longer than the body. Peduncle segments very elongate, lengths 589, 621 and $225 \mu \mathrm{m}$, respectively. Flagellum very long, 33-segmented in the holotype. Aesthetasks about $2 / 3$ as long as the corresponding segment, on segments 10 to 31 in the holotype.

Antenna 2 (fig. 44a) slightly more than half as long as the first. Segments 4 and 5 thin and slender. Flagellum of holotype 14-segmented.

Upper lip as in $M$. curasavicus. Lower lip without trace of inner lobes.

Mandibular palp (fig. 44d): segment 1 unarmed, longer than wide; segment 2 with 3 ventral setae; segment 3 with angular ventral margin, with a row of 10 ' $\mathrm{D}$ '"-setae, decreasing in size from proximal to distal, and 5 (sub)terminal setae. Left and right lacinia mobilis (figs. $44 \mathrm{~b}, \mathrm{c}$ ) as typical of the genus.

Maxilla 1: outer lobe with 10-11 distal spines; innermost spines with 19 medial denticles, remaining spines, from medial to lateral, with 10 to 2 denticles. Inner lobe with about 13 setae. Palps (figs. 44e, f) without particularities.

Maxilla 2 as in $M$. curasavicus. Maxilliped as usual in the genus, basipodite and coxopodite each with a short lateral seta.

Coxal plates 1 and 2 with very well-marked crenulations, in particular on the anterior margin (figs. 44g, 46a, d; 47a, b). Gnathopod 1 (fig. $44 \mathrm{~g}$ ) similar to that of $M$. curasavicus, but palmar angle spines longer, each with 2 long distal cusps (fig. 44g, detail). Gnathopod 2 ( $\left.0^{\circ}\right)$ (fig. 46a): Carpus with 8 groups of setae on posterior margin; propodus large, elongate 


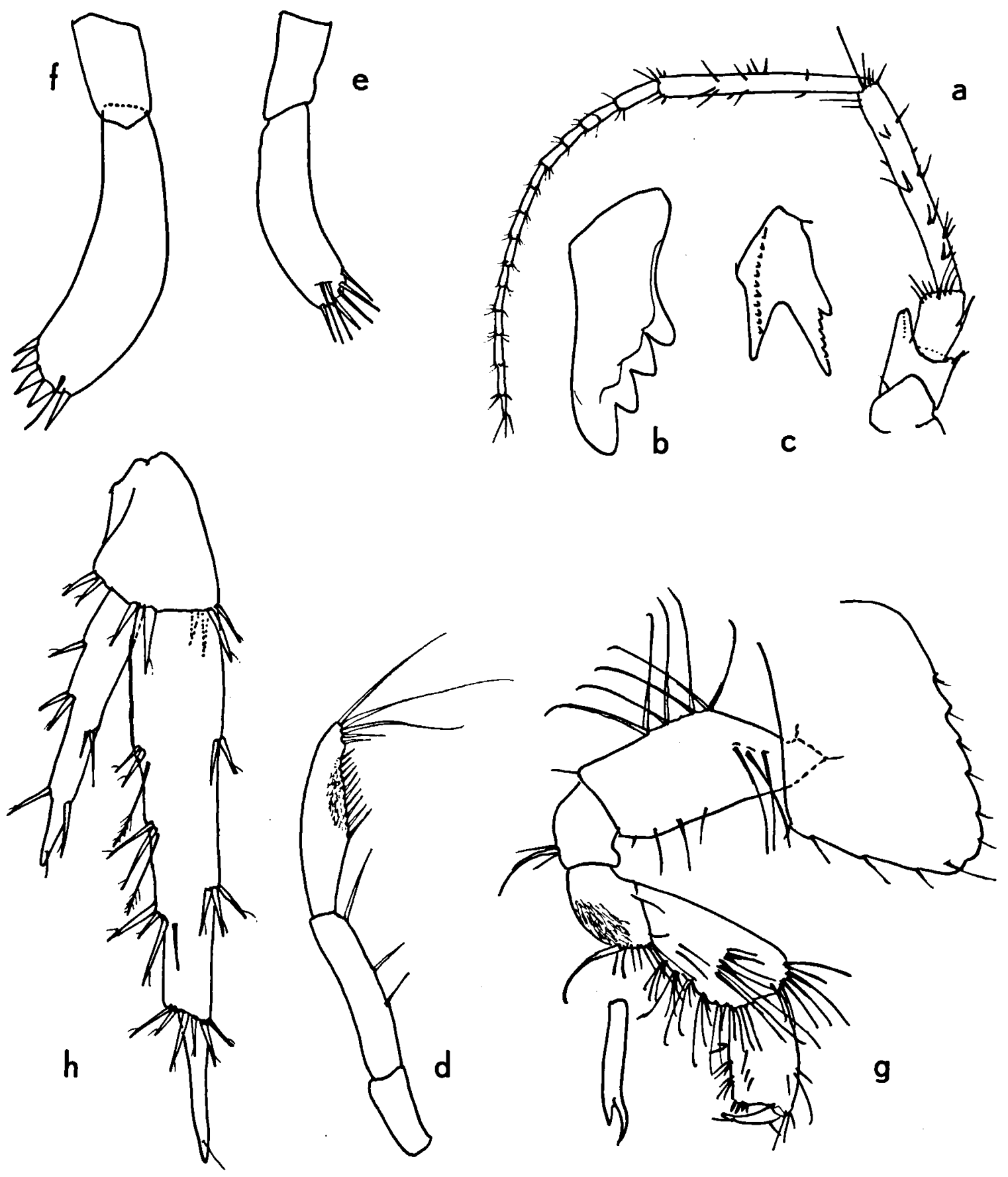

Fig. 44. Metaniphargus (Guadzia) crenatus n. sp. (sta. 79-640): a, second antenna, $\sigma^{\circ}$ (scale 7); b, left lacinia mobilis, $\&$ (5); c, right lacinia mobilis, $\$$ (5); d, mandibular palp, $\$(8)$; e, palp of left first maxilla, $९$ (3); f, palp of right first maxilla, $\uparrow(3) ; \mathrm{g}$, first gnathopod, $\sigma^{\circ}(2) ; \mathrm{h}$, third uropod, $\sigma^{\circ}(2)$. Scales on fig. 11. 


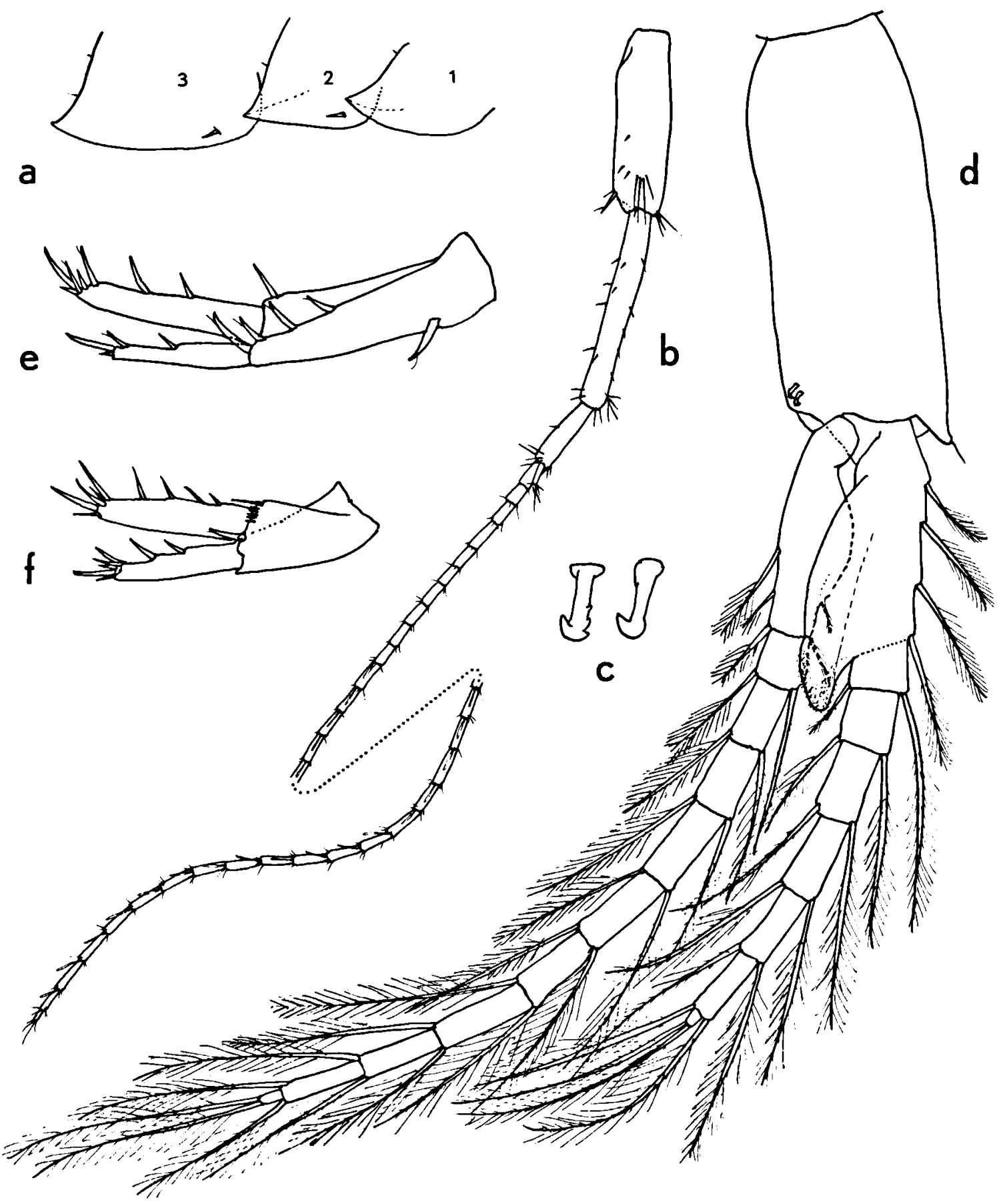

Fig. 45. Metaniphargus (Guadzia) crenatus n. sp. ( $0^{\circ}$, sta. 79-640): a, epimeral plates 1-3 (scale 15); b, first antenna (15); c, retinacula of first pleopod; d, third pleopod (19); e, first uropod (18); f, second uropod (18). Scales on fig. 53. 


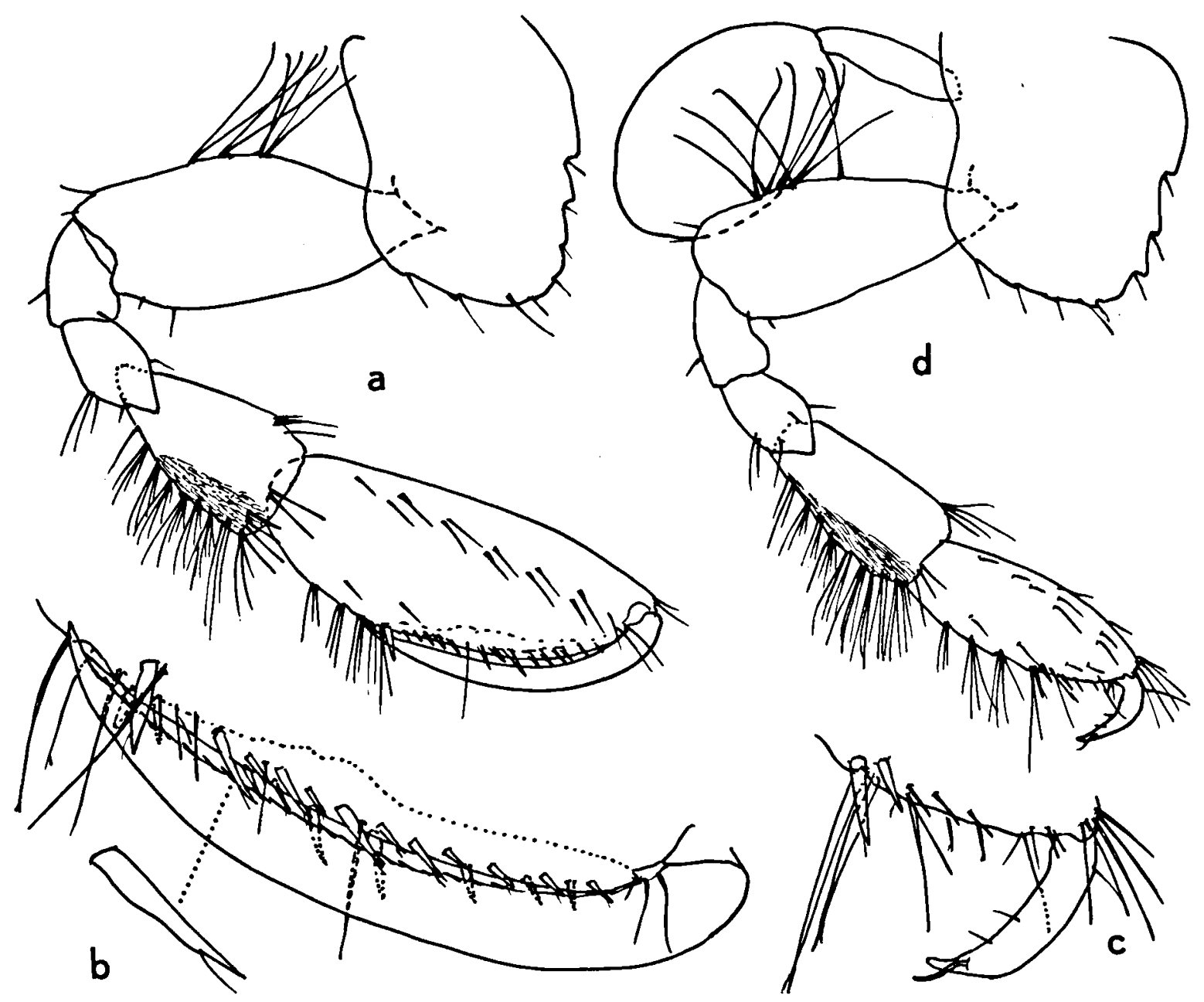

Fig. 46. Metaniphargus (Guadzia) crenatus n. sp. (sta. 79-640): a, second gnathopod, $\sigma$ (scale 2); b, palma of second gnathopod, $\sigma^{\star}$ (3); c, palma of second gnathopod, $९$ (3); d, second gnathopod, $\odot$ (2). Scales on fig. 11.

ovoid; palmar angle with 2 spines, palmar margin with 2 rows, each of about 12 spines; the spines are unequal in size (fig. 46b). Gnathopod 2 ( $\%$ ) (fig. 46d) with very slender carpus; propodus small, ovoid, claw short, palmar angle with 2 spines and 2 strong setae; palmar margin with 2 rows of 3 setae each (fig. 46c).

Pereiopods 3 and 4 as in $M$. bousfieldi, except for the stronger crenulation of the coxal plate (fig. 47c). Pereiopod 5 (fig. 47d): Basis with serrate posterior margin; posterodistal corner produced but not overhanging. Pereiopod 6 resembling the 7th. Pereiopod 7 (fig. 47e) long, slender; basis with serrate posterior margin; propodus and claw with distointerior cilia.

Pleopods without clothpeg spines. Pleopod 3 on strongly sexually dimorphous (fig. 45d). Basal exopodite segments fused, medially with an elongate, rugose lobe, produced in distal direction. Basal endopodite segment with 2 setae of reduced length, and with a modest lateral swelling. Retinacula short, 2 on each pleopod, armed with 1 terminal hook and 0 to 3 auxiliary hooks (fig. 45c).

Epimeral plates (fig. 45a) with a slightly pro- 

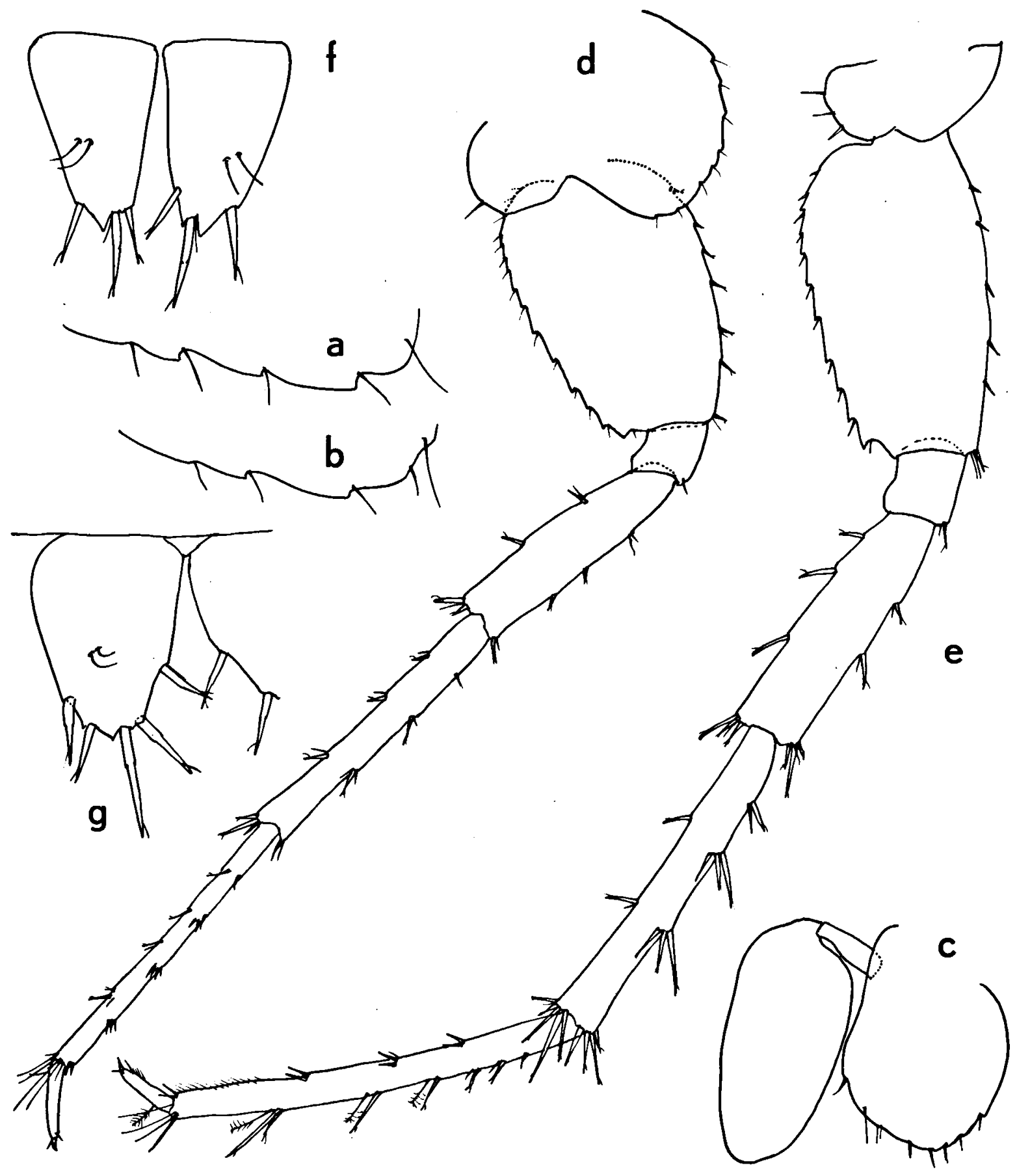

Fig. 47. Metaniphargus (Guadzia) crenatus n. sp. (sta. 79-640): a, b, anterior margin of coxal plates 1 and 2, $९$ (scale 19); c, third coxal plate and gill, $\sigma^{\circ}(18)$; d, fifth pereiopod, $\sigma^{\circ}(18)$; e, seventh pereiopod, $\sigma^{\circ}(18)$; f, telson, $९$ (19); g, telson, $\sigma^{\circ}$ (19). Scales on fig. 53. 
duced, pointed, posteroventral corner. Plates 2 and 3 with a ventroproximal spine. Plate 2 with an oblique stripe.

Uropod 1 (fig. 45e) with strong ventroproximal spine; exopodite with 1 , endopodite with 1 or 2 dorsal spines. Uropod 2 (fig. 45f): Peduncle with a distal row of 1 larger and 5 smaller spinules; rami with 2 to 4 dorsal spines. Uropod 3 (fig. 44h): Endopodite 2/3 of segment 1 of exopodite; endopodite and segment 2 of exopodite tall, narrow, tapering into a point (unarmed but for a minute setule); exopodite segment 2 more than $1 / 3$ of the length of segment 1 . Endopodite without feathered setae, exopodite with a few feathered setae on its medial margin.

Telson (figs. $47 \mathrm{f}, \mathrm{g}$ ): each lobe $1 \frac{1 / 2}{2}$ times as long as wide; outer margin with 1 spine; distal margin with 1 to 3 spines; inner margin with 1 spine; sensory setae short, inserted at $2 / 3$ of the length of the telson lobe.

Remarks. - By the distally produced lobe of the basal exopodite segment(s) of the 3rd male pleopod, the present species differs from all other taxa within the genus Metaniphargus. Also the strong crenulation of the coxal plates 1 to 4 is highly characteristic. From the two species of Guadzia from the Lesser Antilles (from Guadeloupe and Marie-Galante), the new Haitian species differs moreover in the less strongly lobed lateral margin of the basal segment(s) of the endopodite of pleopod 3.

Etymology. - The specific name, crenatus, alludes to the strong crenulation of coxal plates 1 to 4 .

Distribution. - Known from two oligohaline wells in Jérémie (hydrographic zone AA in fig. 4).

\section{Genus Bahadzia Holsinger, 1985}

This genus has been recently created by Holsinger (1985) for two species of stygobiont Amphipoda, one from Great Abaco (Bahamas), the other from Providenciales (Turks and Caicos Islands). Undescribed material of Bahadzia is also known from Cozumel (Mexico) (Hol- singer, in litt.). A form apparently closely related to the taxa described by Holsinger is present in the collections made by the Amsterdam Expeditions to the West Indian Islands, but contrary to the Bahamas and Caicos species, it was found in waters of low salinity, and not in very salty anchihaline cave waters.

This genus exhibits a mixture of hadzioid and weckelioid characters. The close morphological similarity to Mayaweckelia, a weckelioid from the Yucatan region (Mexico), in particular in the first and second gnathopods, and in the absence of spines on the outer lobe of the maxilliped, can hardly be accidental or convergent. Other similarities bear on the structure of the antennae, the pereiopods, the first uropod, and the telson. On the other hand, most weckelioids (though not all) lack a mandibular palp, and all have a 1-segmented exopodite in uropod 3. The widened, club-shaped, palp of the second maxilla of Bahadzia is unique within the entire hadzioid/weckelioid group.

At any rate, Bahadzia bridges the gap between hadzioids and weckelioids to such an extent, that I have no longer separated the two as distinct groups.

\section{Bahadzia latipalpus n. sp.}

(Figs. 48-54)

Material. - One $\subsetneq$ (holotype), one $\sigma$ (allotype), eleven $\$ \&$ and two $\sigma^{\circ} \sigma^{\prime}$ (paratypes). Amsterdam Expeditions to the West Indian Islands, sta. 79-560. Haiti: Dép. de l'Est, Marigot, well of Jacques Simein (at the extreme east of the village) $\left(18^{\circ} 13^{\prime} 51^{\sim} \mathrm{N} 72^{\circ} 18^{\prime} 52^{\sim} \mathrm{W}\right)$; water level at $4 \mathrm{~m}$, water depth $1 \mathrm{~m}$; chlorinity $31 \mathrm{mg} / \mathrm{l}$; temp. $25.0^{\circ} \mathrm{C}$; open, clean well, situated some $300 \mathrm{~m}$ from the coast; 16 Nov. 1979 (ZMA Amph. 107.845).

Two 9 \&. Sta. 79-561. Dép. de l'Est, Marigot, well of Vetirie Lapierre (at the extreme east of the village), near previous station, at about $300 \mathrm{~m}$ from the coast; water level at $6.3 \mathrm{~m}$, water depth $1.2 \mathrm{~m}$; chlorinity $34 \mathrm{mg} / \mathrm{l}$; temp. $25.3^{\circ} \mathrm{C}$; 16 Nov. 1979 (ZMA Amph. 107.846).

Four specimens. Sta. 79-578. Dép. de l'Ouest, Dumonet, ca. $200 \mathrm{~m}$ from Trou Caiman, well of Mrs. Tissé Coriolan, dug into sandy sediments $\left(18^{\circ} 38^{\prime} 58^{\sim} \mathrm{N}\right.$ $72^{\circ} 06^{\circ} 58^{\circ} \mathrm{W}$ ); water level at $5.1 \mathrm{~m}$, water depth $0.9 \mathrm{~m}$; chlorinity $422 \mathrm{mg} / \mathrm{l}$; temp. $27.2^{\circ} \mathrm{C}$; 2 Nov. 1979 (ZMA Amph. 107.847).

Description of type-specimens. - Body length 3.5-4.5 $\mathrm{mm}$; blind, unpigmented. 
Urosomites 1, 2, and 3 (fig. 48b) with a pair of dorsal spines. Cephalosome (fig. 48a) with shallow antennal sinus.

Antenna 1 (fig. 49a) with 26-segmented flagellum; flagellum articles 9 to 24 with an aesthetask, which is at least half as long as the corresponding segment. Accessory flagellum (fig. 48c) 3-segmented, overreaching the 3rd flagellum segment. Peduncle segments 1 to 3 gradually decreasing in length, all three elongate.

Antenna 2 (fig. 49b) with stout gland cone; segments 4 and 5 thin, slender. Flagellum 11-segmented.

Upper lip (fig. 48d) rounded rectangular. Lower lip (fig. 48e) without inner lobes; medial cleft slit-like, narrow.

Mandibles (fig. 48f) slightly asymmetrical in their pars incisiva. Pars molaris on both sides with a very long seta (sometimes absent on the right side). Between the lacinia mobilis and the pars molaris $2+7$ major setae on the right side, $2+8$ on the left side. Lacinia mobilis left with 3 coarse teeth (fig. 48h); right lacinia slender (figs. $48 \mathrm{~g}$, i), with 2 small distal cusps. Palps symmetrical; segment 1 short, unarmed; segment 2 long, slender, thin, unarmed; segment 3 somewhat longer than 2, armed with a ventral row of some 6 spines of a size, 4 longer terminal setae, and a lateral field of minute spinules.

Maxilla 1 (fig. 48j): Palp 2-segmented, segment 2 club-shaped, strongly enlarged in its rounded distal part, armed with 10 spines and 1 or 2 setae; left and right palps similar. Outer lobe with 9 to 10 strongly curved distal spines, the inner margin of which is armed, from medial to lateral, with 7 to $>25$ denticles. Inner lobe pointed, inner margin straight, armed with about 20 plumose setae; no lateral or terminal armature apart from some fine cilia.

Maxilla 2 (fig. 50a): Inner lobe with medial setal armature and diagonal row of numerous setae.

Maxilliped (fig. 50b): Inner and outer lobes widened; inner lobe with 4 distal spines; outer lobe armed with setae only. Palp slender; segment 3 distally slightly lobate; claw slender.
Gnathopod 1 (fig. 51b) with elongate coxal plate, the ventral margin of which is curved. Merus with a very strong membranous posterodistal lobe, armature not marginal, consisting of 2 posterior and 2 distal setae. Carpus with 3 transverse rows of long setae, elongate in shape. Propodus elongate; palm transverse, short; palmar angle with 5 or 6 bifid spines. Palmar margin with 2 setae. Claw short, curved (fig. 51a).

Coxal gills (fig. 49c) elongate ovate, narrowed at the base but not really stalked, present on P2 through P6. Oostegites (fig. 49c) linear, not setose (female in non-reproductive phase), present on P2 through P5.

Gnathopod 2 (fig. 52a): Merus not lobate, carpus elongate and armed with 5 transverse rows of setae. Propodus sexually dimorphous: that of the female (fig. 52a) very narrow, elongate, armed at both margins with 4 to 5 groups of long setae; palma transverse, short; palmar angle with 5 hair-tipped spines (fig. $52 \mathrm{~b}$ ); palmar margin with 2 setae; claw short. That of the male (fig. 52c) is less narrow, the palm is oblique and longer than in the female; palmar angle with $4+2$ setule-tipped spines; palmar margin with 2 rows of 5 spines each; claw longer than in the other sex.

Pereiopod 3 (fig. 49d) similar to the fourth (fig. 53a), but for the coxal plate which is much longer than wide in P3, wider than long and with a shallow posterior emargination in P4. Long leg segments armed with short, isolated setae and spines only.

Pereiopod 5 (fig. 49e) much shorter than the sixth. Basis ovate, posterodistal lobe present, not strongly overhanging. Long segments armed with short spines, isolated or in small groups. Claw slender, inner margin ciliated (fig. 53b).

Pereiopod 6 (fig. 53c): Slightly shorter than pereiopod 7; basis somewhat wider than in P7; posterodistal lobe overhanging. Long leg segments as in P7.

Pereiopod 7 (fig. 53d) as illustrated. Claw not very slender, inner margin ciliated (fig. 53e).

Pleopods biramous, exopodite usually 9-segmented, endopodite 8-segmented. No sexual 


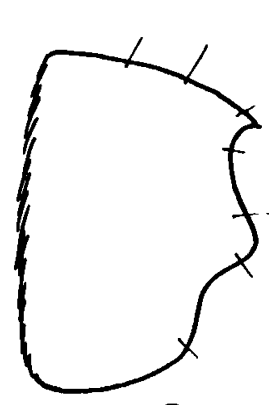

a
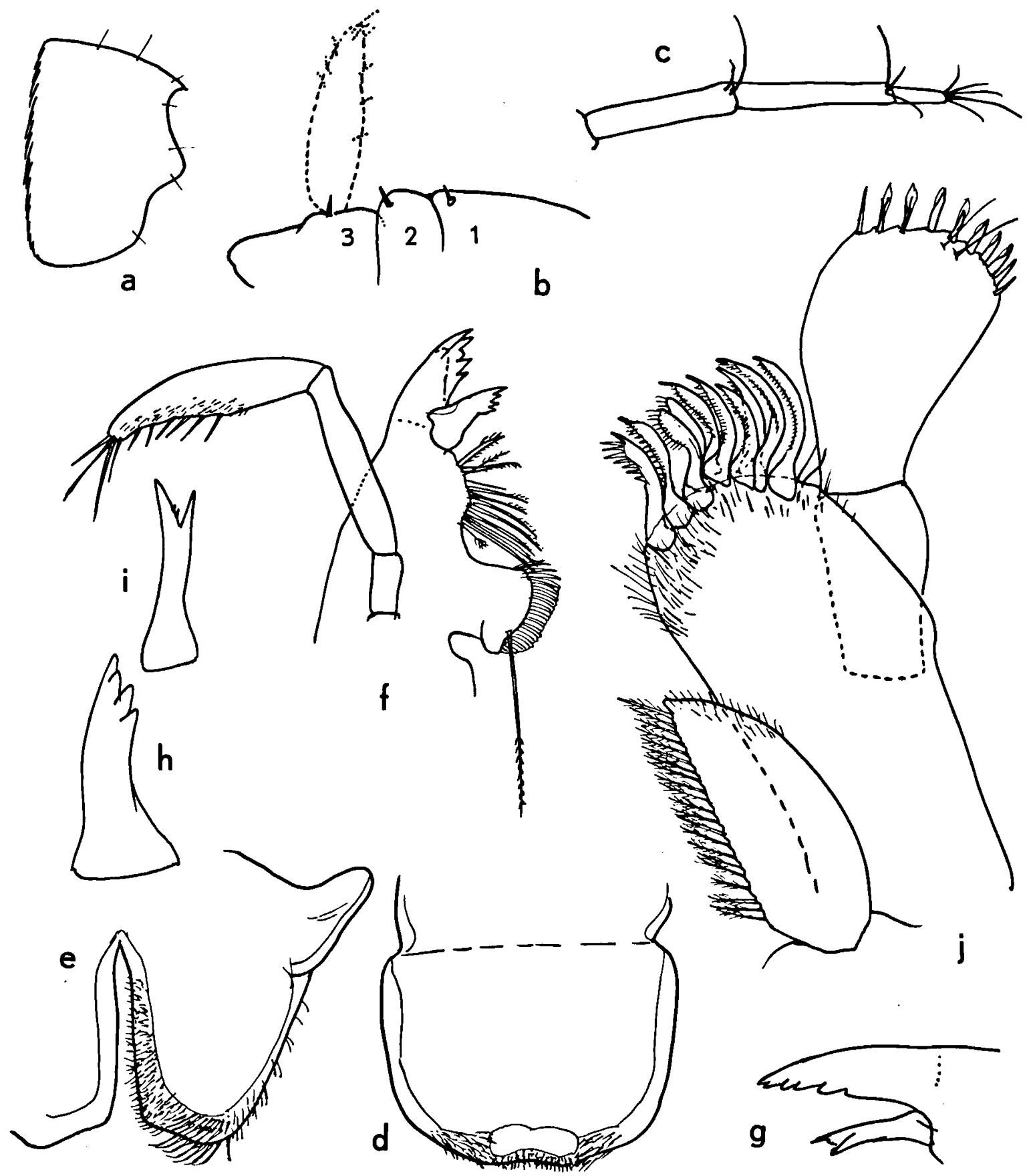

Fig. 48. Bahadzia latipalpus n. sp. (sta. 79-560): a, cephalic segment, from the right, $\sigma^{\circ}$ (scale 7); b, urosomites, from the right, $\sigma^{*}(7)$; c, accessory flagellum, $\$(3)$; d, upper lip, $९$ (8); e, lower lip, $९$ (8); f, left mandible, $\$$ (8); g, pars incisiva of right mancible, $\&(8)$; h, left lacinia mobilis, $९$ (4); i, right lacinia mobilis, $९$ (4); j, first maxilla, $\$$ (3). Scales on fig. 11. 

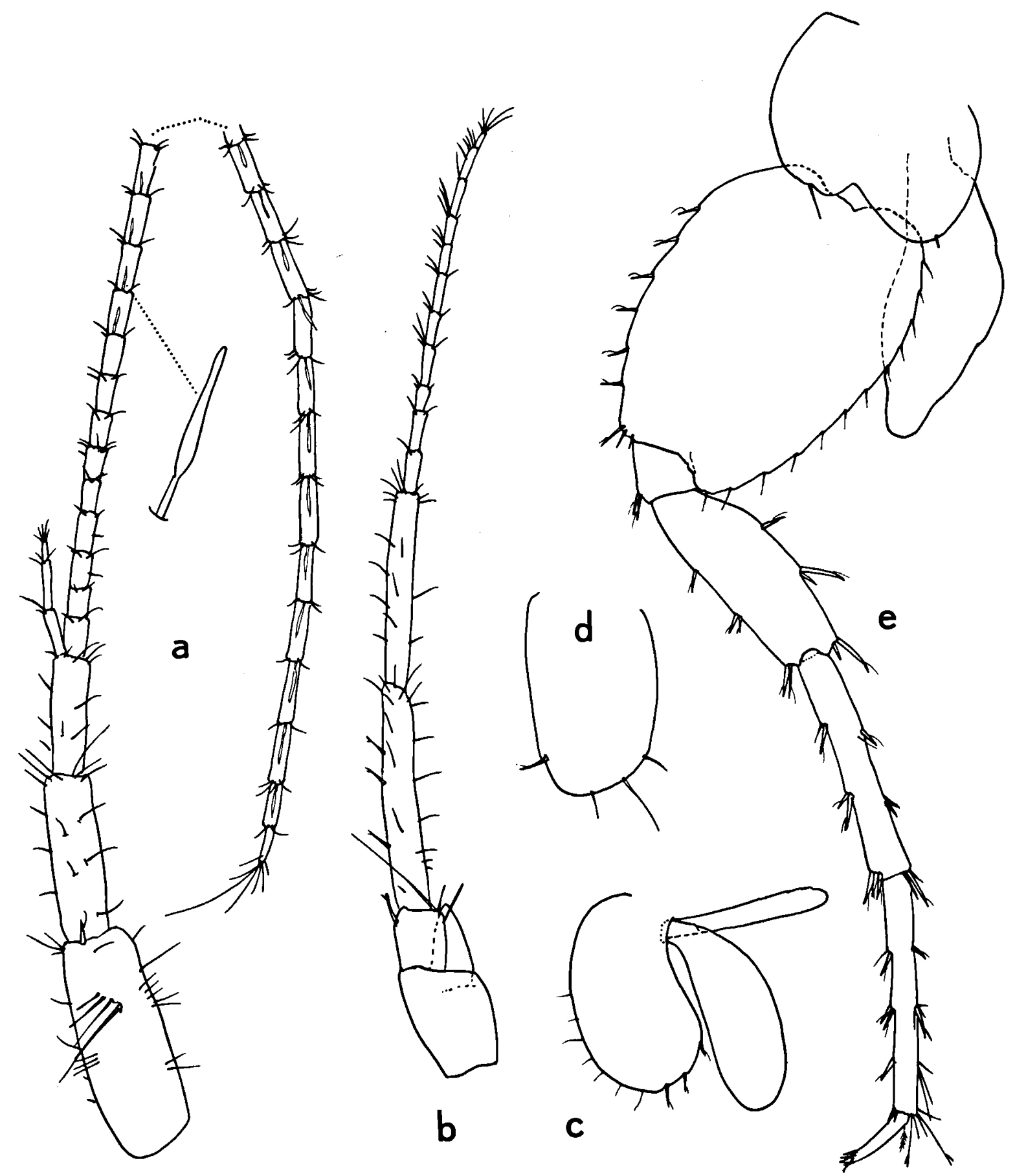

Fig. 49. Bahadzia latipalpus n. sp. ( 9 , sta. 79-560): a, first antenna (scale 18); b, second antenna (18); c, coxal plate, gill and oostegite of second gnathopod (18); d, third coxal plate (18); e, fifth pereiopod (18). Scales on fig. 53. 

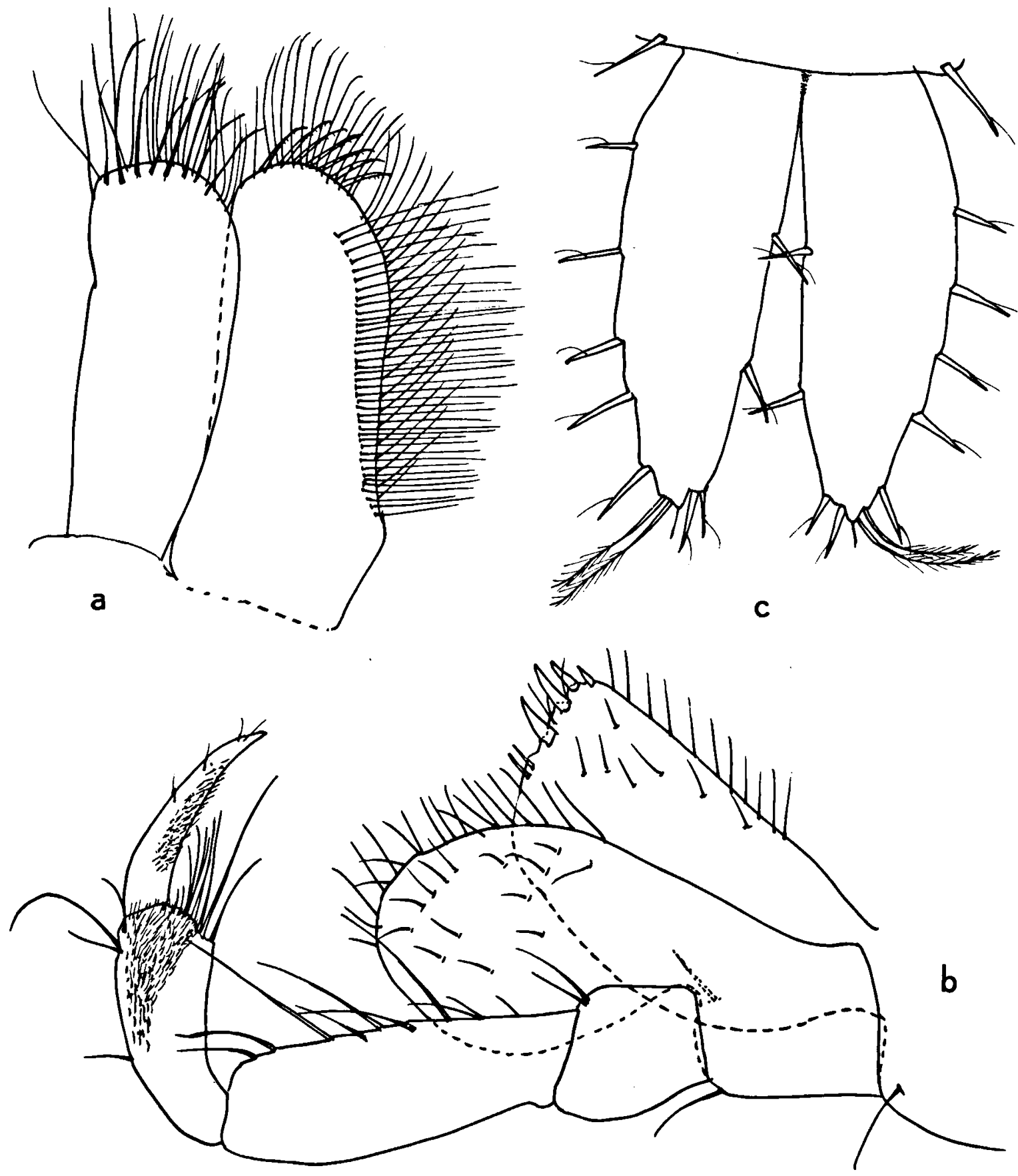

Fig. 50. Bahadzia latipalpus n. sp. ( 9 , sta. 79-560): a, second maxilla (scale 3); b, maxilliped (3); c, telson (8). Scales on fig. 11. 

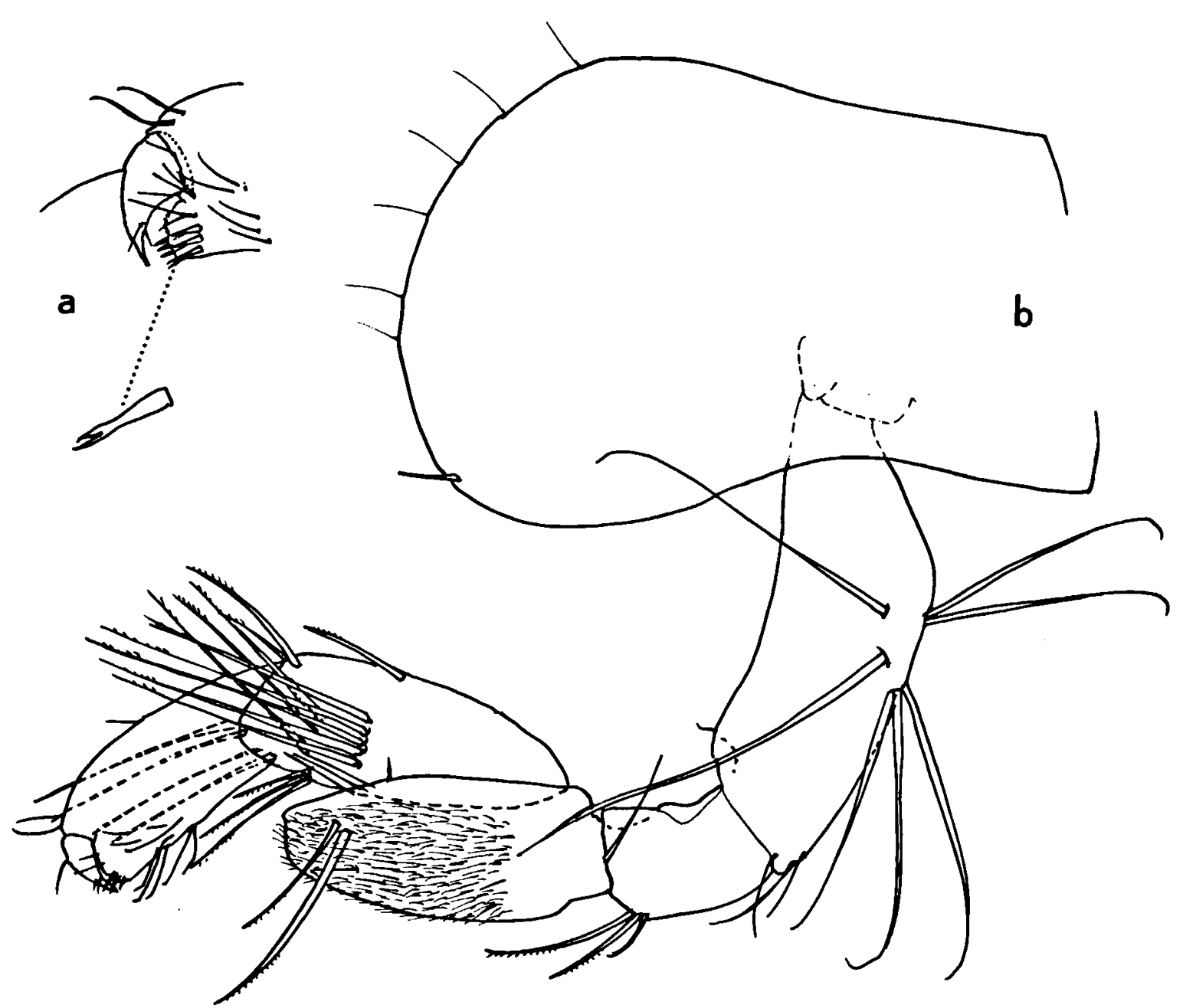

Fig. 51. Bahadzia latipalpus n. sp. ( $Q$, sta. 79-560): a, palma of first gnathopod; b, first gnathopod (scale 8). Scale on fig. 11.

dimorphism. Three clothpeg spines on the medial margin of endopodite segment 1 , none on pleopods 2 and 3. Retinacula: 2 on each pleopod, very elongate, ending in a distal hook and having 2 subdistal, unilateral teeth (fig. 54b).

Epimeral plates (fig. 54a): Posteroventral corner ending in a small point; posterior and ventral margins unarmed in plates 1 and 2; plate 3 with 1 setule on its posterior margin and 1 strong, setule-tipped spine on the ventral margin.

Uropod 1 (fig. 54c) without proximoventral spine, but with a spine near its base, on the first urosomite. Pedunculus elongate; rami subequal, elongate; both rami with 2 dorsal spines.

Uropod 2 (fig. 54d): Exopodite slightly shorter than endopodite; endopodite not overreaching uropod 1 .

Uropod 3 (fig. 54e) with foliaceous endopodite. Exopodite narrower than endopodite and slightly shorter, 2-segmented. Peduncle not elongated. Outer and inner margins of endopodite and inner margin of exopodite with plumose setae and isolated spines.

Telson (fig. 50c) cleft to almost its base. Telson halves very elongate; lateral margin with 5 spines, medial margin with 2 or 3 spines; 


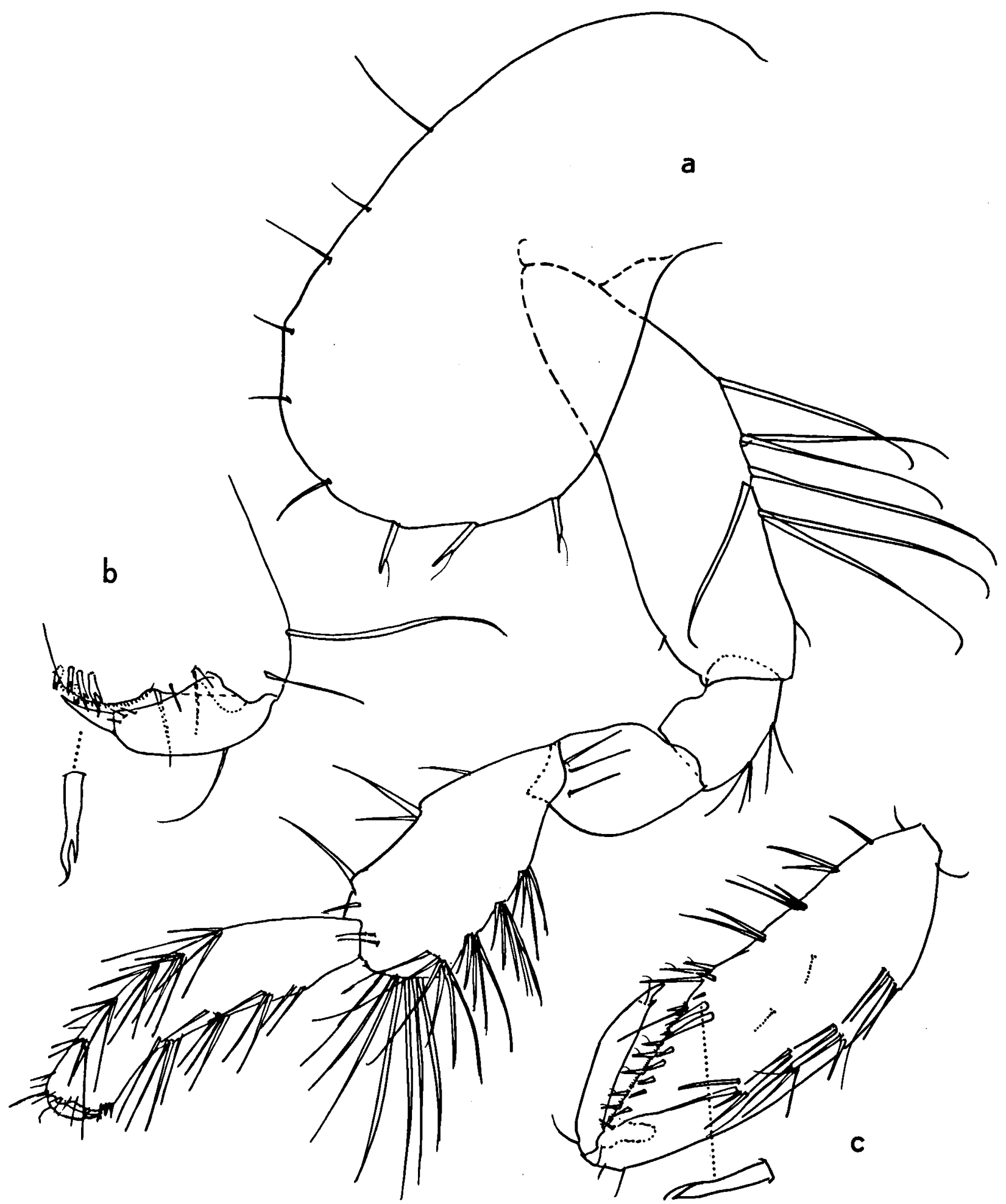

Fig. 52. Bahadzia latipalpus n. sp. (sta. 79-560): a, second gnathopod, $\$$ (scale 8); b, palma of second gnathopod, ㅇ (5); c, propodus of second gnathopod, $\sigma(8)$. Scales on fig. 11. 

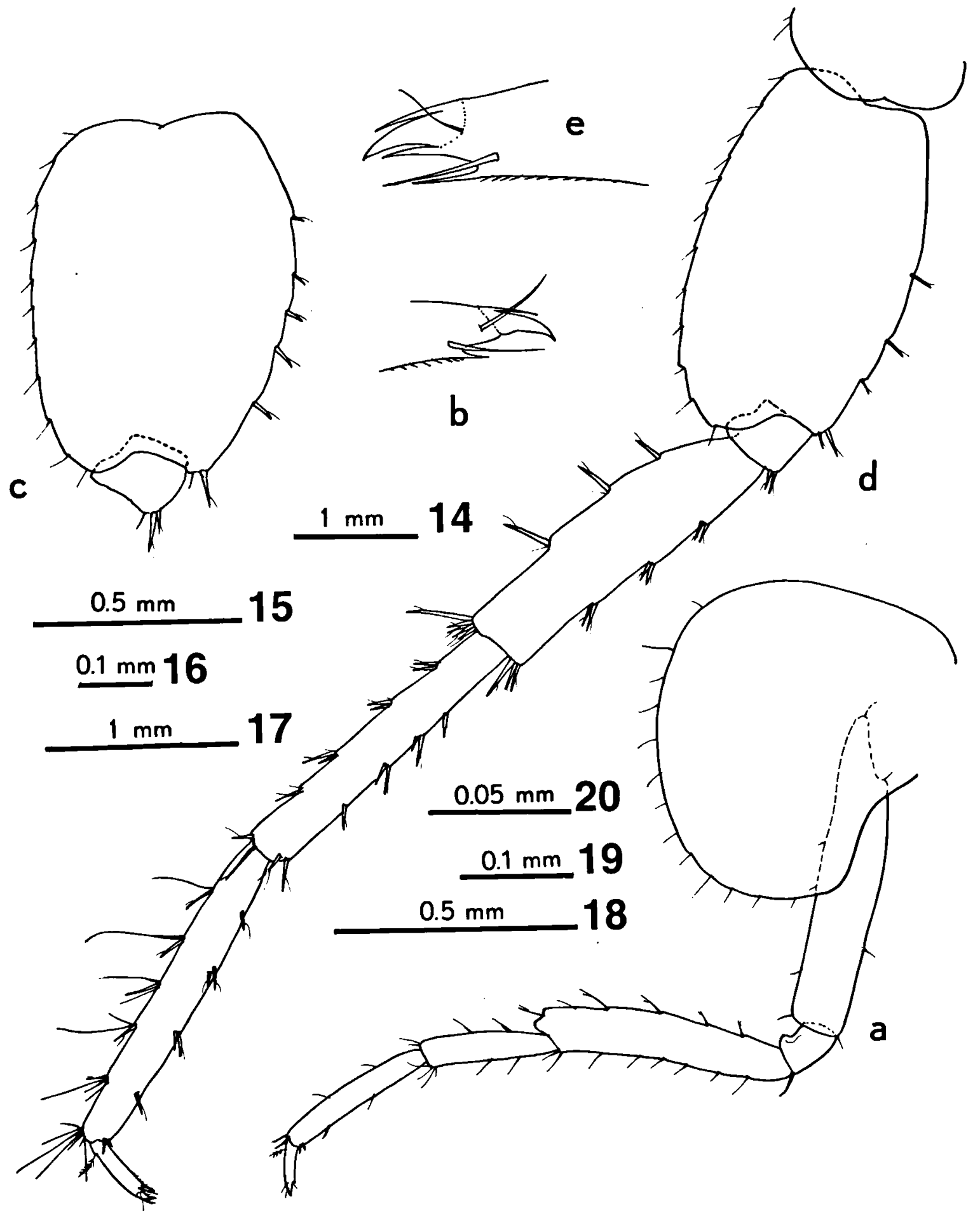

Fig. 53. Bahadzia latipalpus n. sp. ( $\$$, sta. 79-560): a, fourth pereiopod (scale 18); b, claw of fifth pereiopod (20); c, basal part of sixth pereiopod (18); d, seventh pereiopod (18); e, claw of seventh pereiopod (20). 


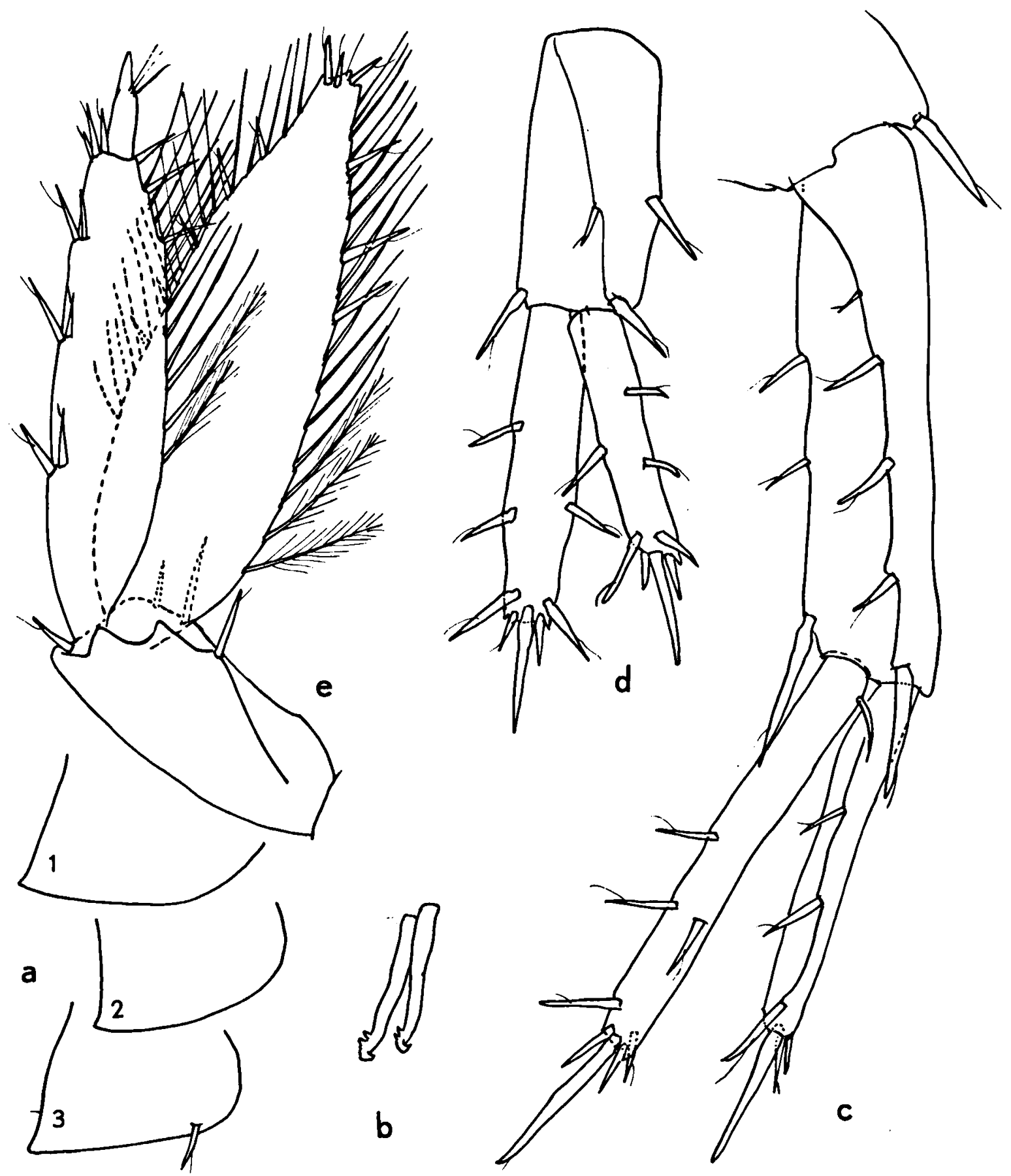

Fig. 54. Bahadzia latipalpus n. sp. ( $($, sta. 79-560): a, epimeral plates 1-3 (scale 7); b, retinacula of third pleopod (5); c, first uropod (8); d, second uropod (8); e, third uropod, plumosity of the long setae only partly shown (8). Scales on fig. 11. 
distal armature of 2 long sensorial setae and 2 spines.

Secondary sexual dimorphism restricted to the propodus of gnathopod 2.

Remarks. - The specimens from sta. 79-561 and sta. 79-578 are slightly larger than the typespecimens ( $4 \frac{1}{2}-5 \mathrm{~mm}$ body length). The largest specimen from sta. 79-561, a female, with nonsetose oostegites, differs in two respects from the types: (1) the second maxilla bears, in addition to the usual oblique row of setae on the inner lobe, two additional rows, of 7 and 3 setae, respectively; (2) the lateral margin of the telson lobes bears 6 spines (left) or 7 spines (right), the medial margin bears 3 spines.

Distribution. - Known from 2 stations in hydrographic zone $\mathrm{O}$ (Cayes/Jacmel zone, near Marigot, see fig. 3) and 1 station in the adjacent zone M (Cul-de-Sac zone, near Trou Caiman, fig. 3), in fresh and oligohaline waters.

Distinction. - The Haitian species is in most characters very similar to $B$. williamsi Holsinger, 1985, from Great Abaco (Bahamas) and B. stocki Holsinger, 1985, from Providenciales (Turks and Caicos Islands). The most salient differences are found in P1 and P2: the lobe of the merus of $\mathrm{P} 1$ is much more produced in $B$. latipalpus than in the two other species, and the propodus of $\mathrm{P} 2$ is much longer than the carpus in $B$. latipalpus, shorter in the two other species. Additional differences reside in the ventral row of setae on mandibular palp segment 3 (6 in latipalpus, about 16 in the two others), and the number of pectinate spines on the outer lobe of the first maxilla (9-10 in latipalpus, 8 in the two others).

\section{Zombiweckelia n. gen.}

Characterization. - Similar to Alloweckelia Holsinger \& Peck, 1968 (a monotypic genus from caves in Puerto Rico), but differing in (1) the peduncle of the first antenna, which is of the "gammaroid" type, i.e. segment $2<1$, cf. Bousfield, 1977, table IX (in Alloweckelia it is of the "'melitoid" type, i.e. segment $2 \geqq 1$ ); (2) the accessory flagellum of the first antenna, which is long and 3-segmented (short and 2-segmented in Alloweckelia); (3) the mandibular palp, which is reduced (2- to 3-segmented, entire palp miniaturized, not reaching beyond the lacinia mobilis; its armature is restricted to a single distal seta); (4) the telson which is completely cleft (cleft to about $2 / 3$ in Alloweckelia); (5) the telson lobes which are elongate (plesiomorphous state, cf. Stock, 1983: 283), versus shortened (apomorphous state) in Alloweckelia.

The new genus is also similar to Weckelia Shoemaker, 1942 (a genus of cavernicolous amphipods from Cuba), but it differs in (1) the presence of spines on the palmar margin of gnathopod 1 ("ceradocid or melitid form" of Barnard \& Barnard, 1983), versus armed with setae only ("hadziid form") in Weckelia; (2) the absence of inner lobes on the lower lip (present in Weckelia); (3) the plesiomorphous shape of the telson lobes (see point 5 above); (4) the "gammaroid" type of the peduncle of the first antenna (see point 1 above); (6) the presence of a 2- to 3-segmented mandibular palp (a 1-segmented bud in Weckelia).

Type-species. - Zombiweckelia parvipalpus n. sp. The genus is so far monotypic.

Etymology. - Generic name from zombi (in Haitian Voodoo religion, a phantom or someone resurrected), alluding to the subterranean habitat of these amphipods, in combination with the old generic name Weckelia. The specific name, parvipalpus (with a small palp) points to the miniaturized mandibular palp.

\section{Zombiweckelia parvipalpus n. sp.} (Figs. 55-60)

Material. - One ovigerous $\$$ (holotype), one $\sigma$ (allotype), more than hundred paratypes. Amsterdam Expeditions to the West Indian Islands, sta. 78-224. Haiti: Dép. de l'Ouest, two karst springs E.S.E. of the hamlet of Fond Parisien $\left(18^{\circ} 29^{\prime} 19^{\sim} \mathrm{N} 71^{\circ} 56^{\circ} 25^{\wedge} \mathrm{W}\right)$, at 4 and $6 \mathrm{~m}$ from the shore of l'Etang Saumâtre; moderately fast running springs; stones, sand, roots; chlorinity $130 \mathrm{mg} / \mathrm{l}$; temp. not recorded; 7 May 1978 (ZMA Amph. 107.828).

Eight specimens. Sta. 79-531. Dép. de l'Ouest, hamlet Cazeau (Croix-des-Missions), well of Jacques Moyse 

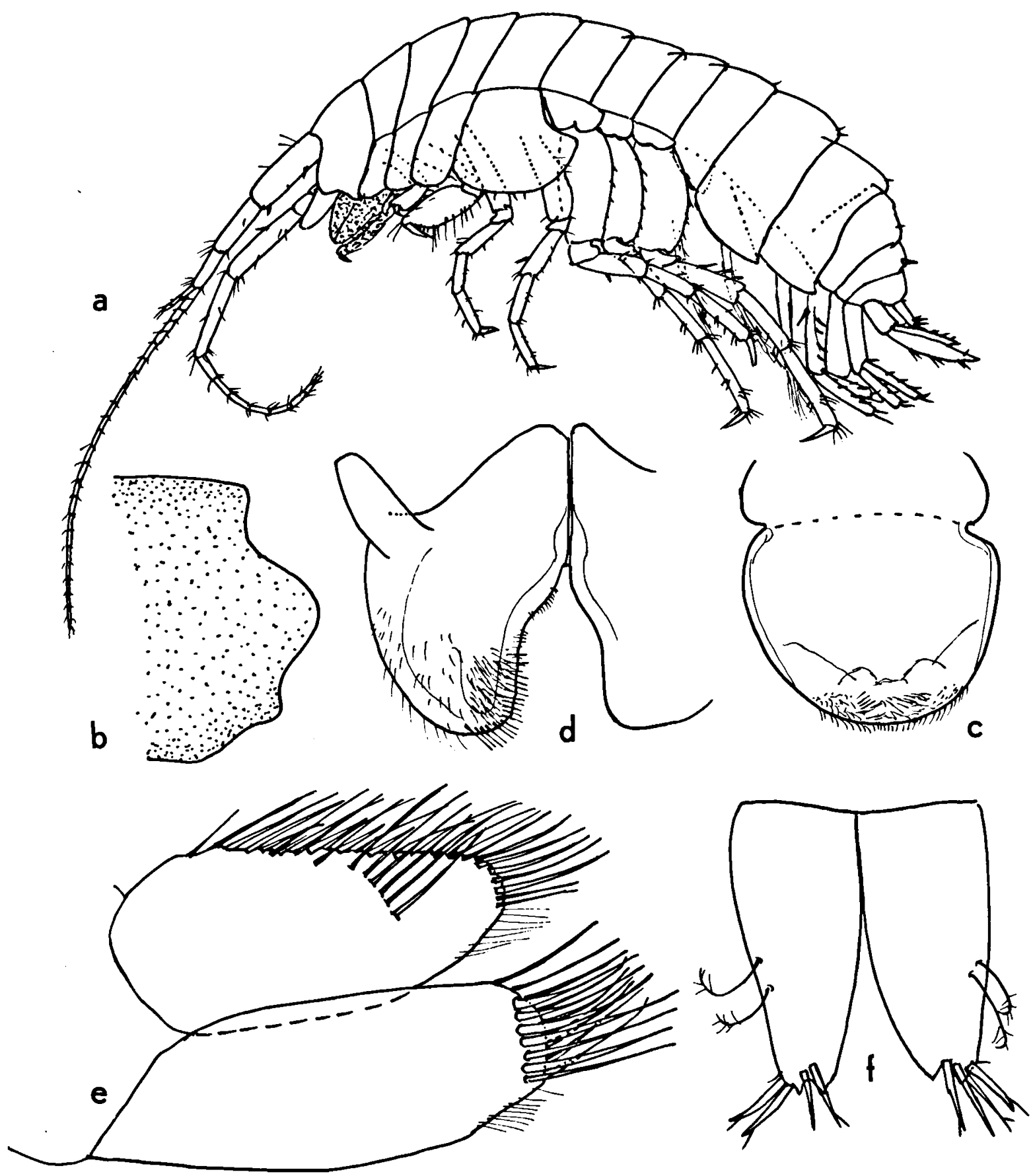

Fig. 55. Zombiweckelia parvipalpus n. gen., n. sp. (all from sta. 78-224, but for a, from sta. 79-620): a, female, from the left (actual size $3 \mathrm{~mm}$ ); b, cephalic segment, \&, from the right (scale 2); c, upper lip, \& (3); d, lower lip, \& (3); e, second maxilla, 9 (4); f, telson, $\sigma^{\circ}(3)$. Scales on fig. 11. 
$\left(18^{\circ} 35^{\circ} 13^{\sim} \mathrm{N} 72^{\circ} 16^{\circ} 57^{\sim} \mathrm{W}\right.$; well dug in alluvia and soil; chlorinity $42 \mathrm{mg} / \mathrm{l}$; temp. $27.5^{\circ} \mathrm{C}$; 10 Nov. 1979 (ZMA Amph. 107.829).

Three specimens. Sta. 79-533. Dép. de l'Ouest, hamlet Cazeau (at Groureau, Croix-des-Missions), well Groureau $\left(18^{\circ} 34^{\prime} 53^{\sim} \mathrm{N} 72^{\circ} 16^{\prime} 16^{\sim} \mathrm{W}\right)$; water level at $3 \mathrm{~m}$, water depth $1.75 \mathrm{~m}$; chlorinity $43 \mathrm{mg} / \mathrm{l}$; temp. $27.3^{\circ} \mathrm{C} ; 10$ Nov. 1984 (ZMA Amph. 107.830).

One $\sigma$. Sta. 79-579. Dép. de l'Ouest, about $200 \mathrm{~m}$ from Trou Caiman, well of Louimes Daibou at Dumonet $\left(18^{\circ} 38^{\prime} 58^{\sim} \mathrm{N} 72^{\circ} 06^{\prime} 58^{\sim} \mathrm{W}\right)$; partly covered well dug in sand and gravel; water level at $3.5 \mathrm{~m}$, water depth $1 \mathrm{~m}$; chlorinity $304 \mathrm{mg} / 1$; temp. $27.3^{\circ} \mathrm{C}$; 21 Nov. 1979 (ZMA Amph. 107.831).

Six specimens. Sta. 79-582. Dép. de l'Ouest, village Debas, well of Mrs. Vernissen (distance to Trou Caiman at least $300-400 \mathrm{~m})\left(18^{\circ} 38^{\prime} 51^{\sim} \mathrm{N} 72^{\circ} 06^{\prime} 34^{\sim} \mathrm{W}\right)$; water level at $4 \mathrm{~m}$, water depth $1.5 \mathrm{~m}$; chlorinity $48 \mathrm{mg} / \mathrm{l}$; temp. $27.0^{\circ}$ C; 21 Nov. 1979 (ZMA Amph. 107.832).

One hundred and ten specimens. Sta. 79-584. Dép. de l'Ouest, rheocrene spring complex called Gongon, on the border of l'Etang Saumâtre, between the hamlets of $l^{\prime}$ Etang and Fond Pite $\left(18^{\circ} 38^{\prime} 54^{\prime \prime} \mathrm{N} 72^{\circ} 02^{\prime} 06^{\prime \prime} \mathrm{W}\right)$; sand, limestone, rich vegetation; chlorinity $23 \mathrm{mg} / \mathrm{l}$; temp. $22.2^{\circ}$ C; 21 Nov. 1979 (ZMA Amph. 107.833).

Five specimens. Sta. 79-587. Dép. de l'Ouest, hamlet $1^{\prime}$ Etang, well of Montezy Imachilis $\left(18^{\circ} 38^{\circ} 38^{\prime} \mathrm{N}\right.$ $72^{\circ} 03^{\circ} 48^{\sim} \mathrm{W}$ ); dug in sandy soil, water level at $5 \mathrm{~m}$, water depth $0.9 \mathrm{~m}$; chlorinity $48 \mathrm{mg} / \mathrm{l}$; temp. $27.8^{\circ} \mathrm{C}$; 21 Nov. 1984 (ZMA Amph. 107.834).

Seven specimens. Sta. 79-588. Dép. de l'Ouest, well of the Presbytère (= Rectory) of Thomazeau $\left(18^{\circ} 39^{\prime} 08^{\prime} \mathrm{N}\right.$ $72^{\circ} 05^{\prime} 26^{\sim} \mathrm{W}$ ); well in sandy soil with pebbles; water level at $9 \mathrm{~m}$, water depth $1 \mathrm{~m}$; chlorinity $60 \mathrm{mg} / \mathrm{l}$; temp. $24.8^{\circ}$ C; 21 Nov. 1979 (ZMA Amph. 107.835).

Nine specimens. Sta. 79-619. Dép. de l'Ouest, Arcahaie (section Merotte), well of Pierre Jeanlouis $\left(18^{\circ} 46^{\prime} 51^{\prime} \mathrm{N}\right.$ $72^{\circ} 31^{\prime} 35^{\wedge} \mathrm{W}$ ), open well dug in sand and gravel, ca. $2 \mathrm{~km}$ from the sea; water level at $8 \mathrm{~m}$, water depth $2 \mathrm{~m}$; chlorinity $44 \mathrm{mg} / \mathrm{l}$; temp. $27.6^{\circ} \mathrm{C}$; 24 Nov. 1979 (ZMA Amph. 107.836).

Fifteen specimens. Sta. 79-620. Dép. de l'Ouest, Arcahaie (quarter Cortade), well of Boss Raoul Bélizaire (estimated position $18^{\circ} 46^{\prime} \mathrm{N} 72^{\circ} 31^{\prime} \mathrm{W}$ ); open well, dug in sand; distance to the sea much less than in sta. 79-619; water level at $3.2 \mathrm{~m}$, water depth $4 \mathrm{~m}$; clean; chlorinity 17 mg/l; temp. 26.9 ${ }^{\circ}$ C; 24 Nov. 1979 (ZMA Amph. 107.837).

Description. - Body length 2.5-3 mm (fig. 55a). Blind, unpigmented. Cephalosome with shallow antennal sinus (fig. 55b). Eggs few in number (1 to 4 ).

Antenna 1 (fig. 56a) about half as long as the body, longer than antenna 2. Peduncle segments not slender, 2nd segment $60 \%$ of the length of the first, 3rd segment $60 \%$ of the length of the second. Accessory flagellum as long as the basal 3 flagellum segments, 3-segmented. Flagellum 17-segmented, distal segments very slender. Aesthetasks on segments 7 to 15 , their length from slightly less to slightly more than half the length of the corresponding segment.

Antenna 2 (fig. 56b) with robust gland cone. Peduncle segments 4 and 5 not very slender. Flagellum 8-segmented.

Upper lip (fig. 55c) rounded-trapezoidal. Lower lip (fig. 55d) with vestigial inner lobes.

Mandibles asymmetrical (figs. 56c, d). The right mandible bears a long, plumose seta on the molar, absent in the left appendage. The lacinia mobilis (right) is bifid and finely toothed; left it is simple, bearing 3 teeth only. The palp is very weak, almost rudimentary, and variable: sometimes it is 2-segmented (fig. $56 \mathrm{e}$ ), but in other specimens (or on the contralateral side of the same specimen) it is 3-segmented (fig. 56f). The entire palp is miniaturized, its distal segment not depassing the insertion of the lacinia. Its armature consists always of a single terminal seta.

Maxilla 1 (fig. 57a): Inner lobe pointed, narrow, with some 11 medial setae. Outer lobe with 7 distal spines, the number of medial teeth on these spines is, from medial to lateral, 8, 6, 5, 7, 3, 3, and 3. Palp 2-segmented, segment 2 (left) with 4 slender distal spines, segment 2 (right) wider and with 4 more robust spines (fig. 57b).

Maxilla 2 (fig. 55e): Inner lobe with an oblique row of up to 20 setae.

Maxilliped (fig. 59a): Inner lobe with 3 flat distal spines, all, or the medial two, bifid. Outer lobe with 6 flat distal spines. Palp segment 3 slightly lobate. Claw with small nail.

Gnathopod 1 (fig. 57c): Basis with long setae at its posterior margin; anterior margin with 2 short distal setae $\left(O^{*}\right)$ or 2 short distal setae and 2 or 3 short marginal setae ( $\$$, fig. 59b). Coxal plate trapezoidal. Merus with patch of spinules. Carpus longer than propodus. Propodus rectangular; palm short, transverse, with 1 angle 


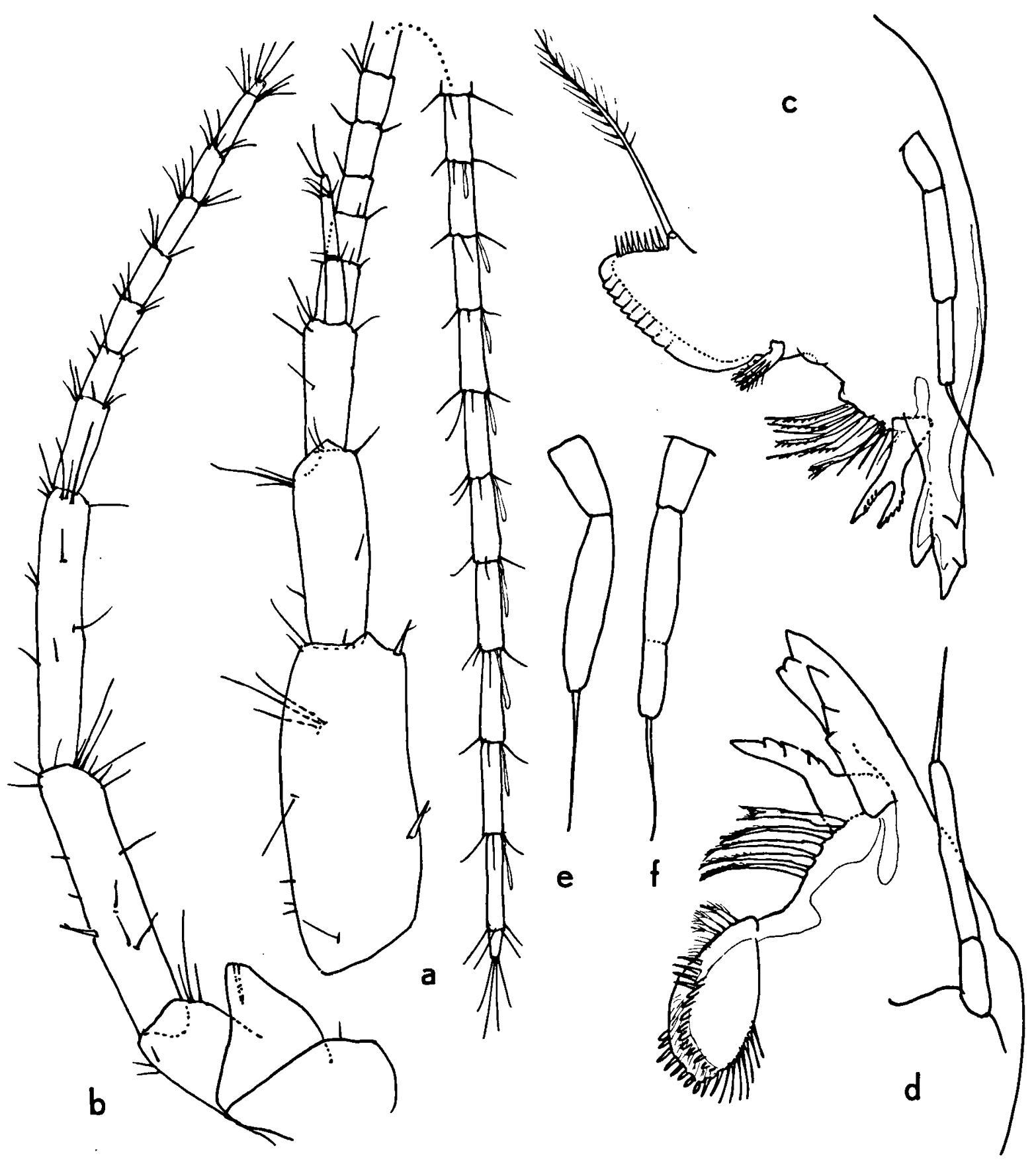

Fig. 56. Zombiweckelia parvipalpus n. gen., n. sp. (sta. 78-224): a, first antenna, $\$$ (scale 8); b, second antenna, $\$$ (8); c, right mandible, $\$$ (4); d, left mandible, $Q$ (4); e, f, palps of contralateral mandibles of a single $0^{\circ}$ specimen (4). Scales on fig. 11. 


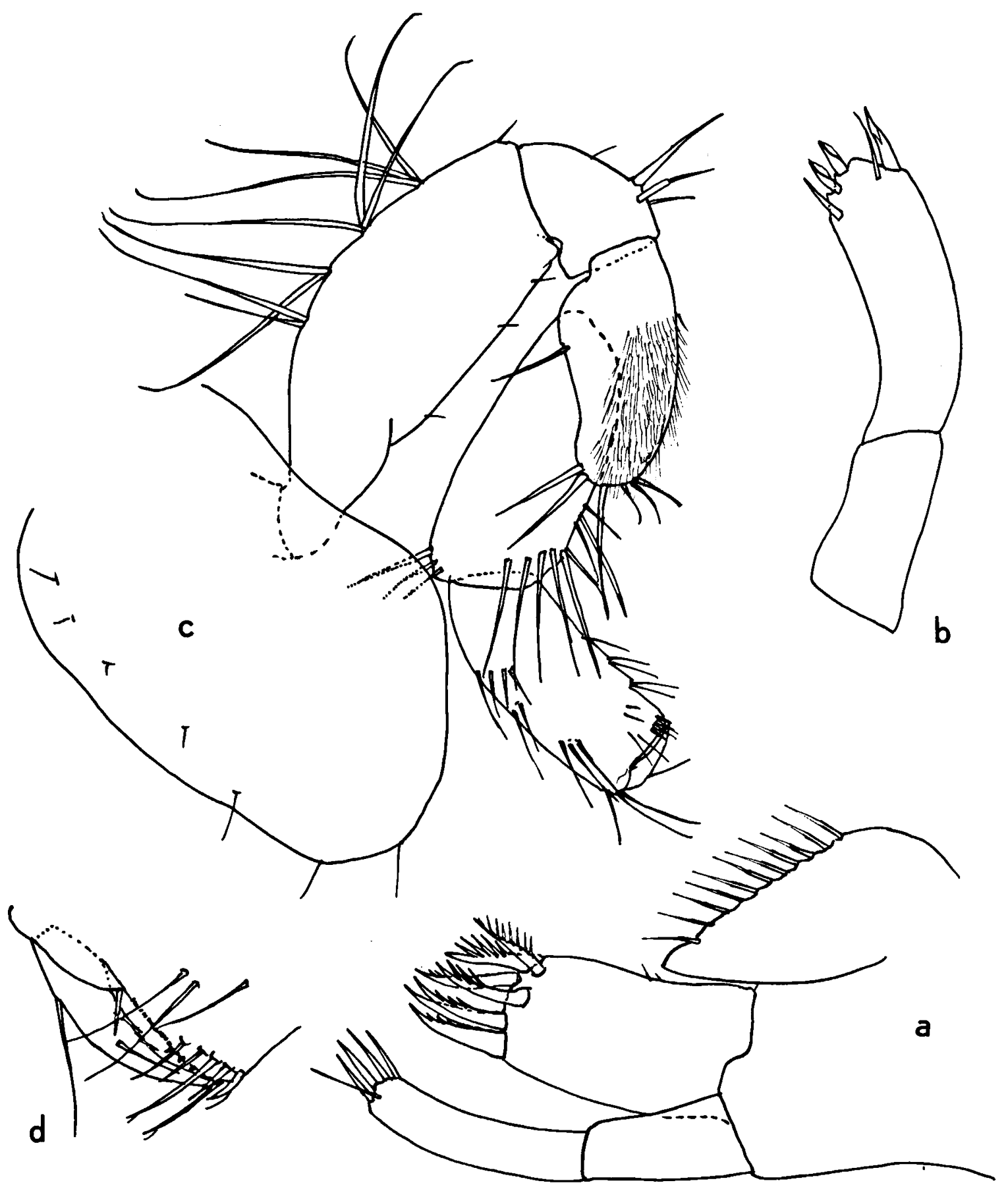

Fig. 57. Zombiweckelia parvipalpus n. gen., n. sp. (sta. 78-224): a, left first maxilla, $\$$ (scale 4); b, palp of right first maxilla, $\$$ (4); c, first gnathopod, ơ (3); d, palma of first gnathopod, $\sigma^{*}(5)$. Scales on fig. 11. 


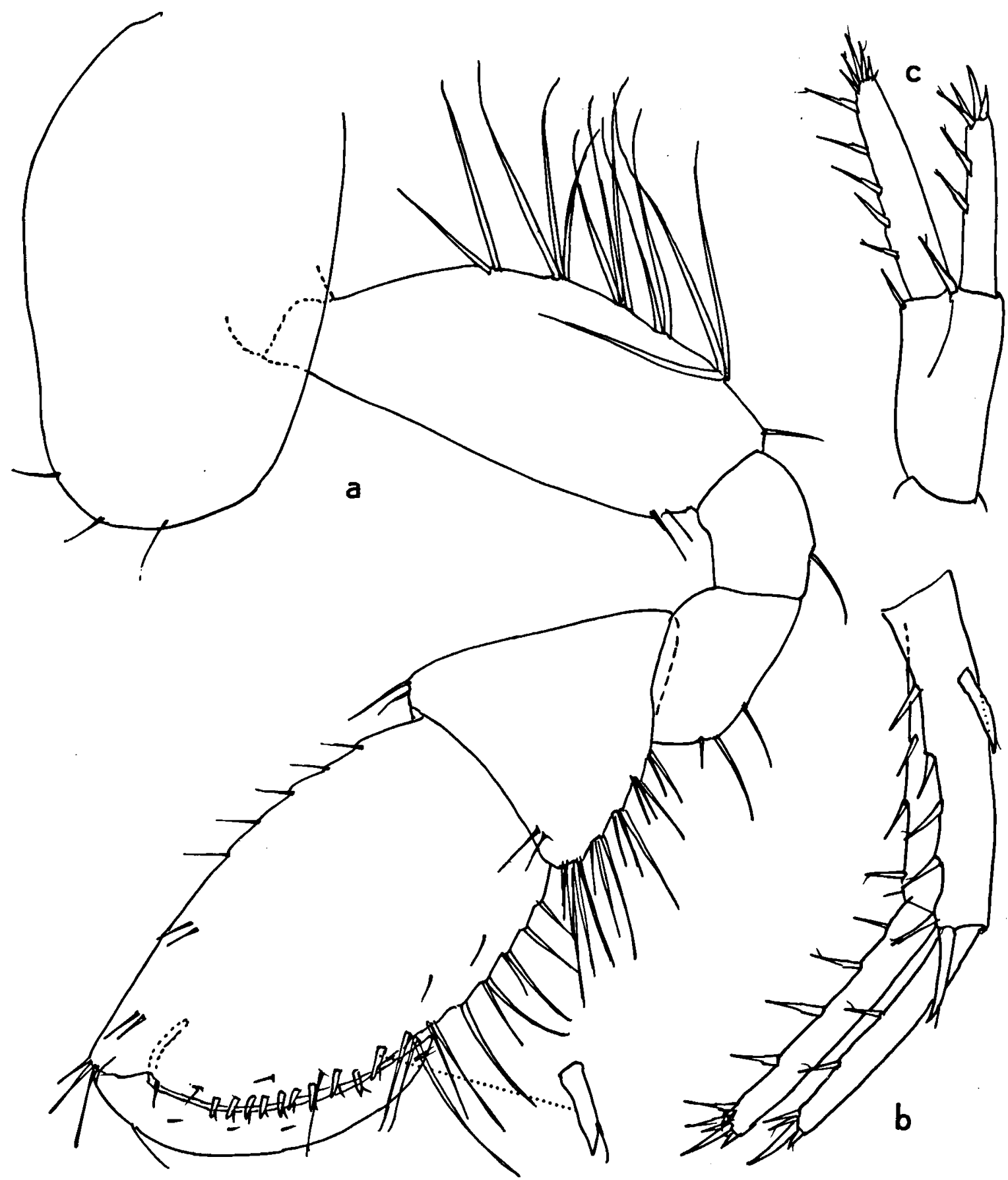

Fig. 58. Zombiweckelia parvipalpus n. gen., n. sp. (sta. 78-224): a, second gnathopod, o* (scale 3); b, first uropod, ९ (8); c, second uropod, $Q$ (8). Scales on fig. 11. 


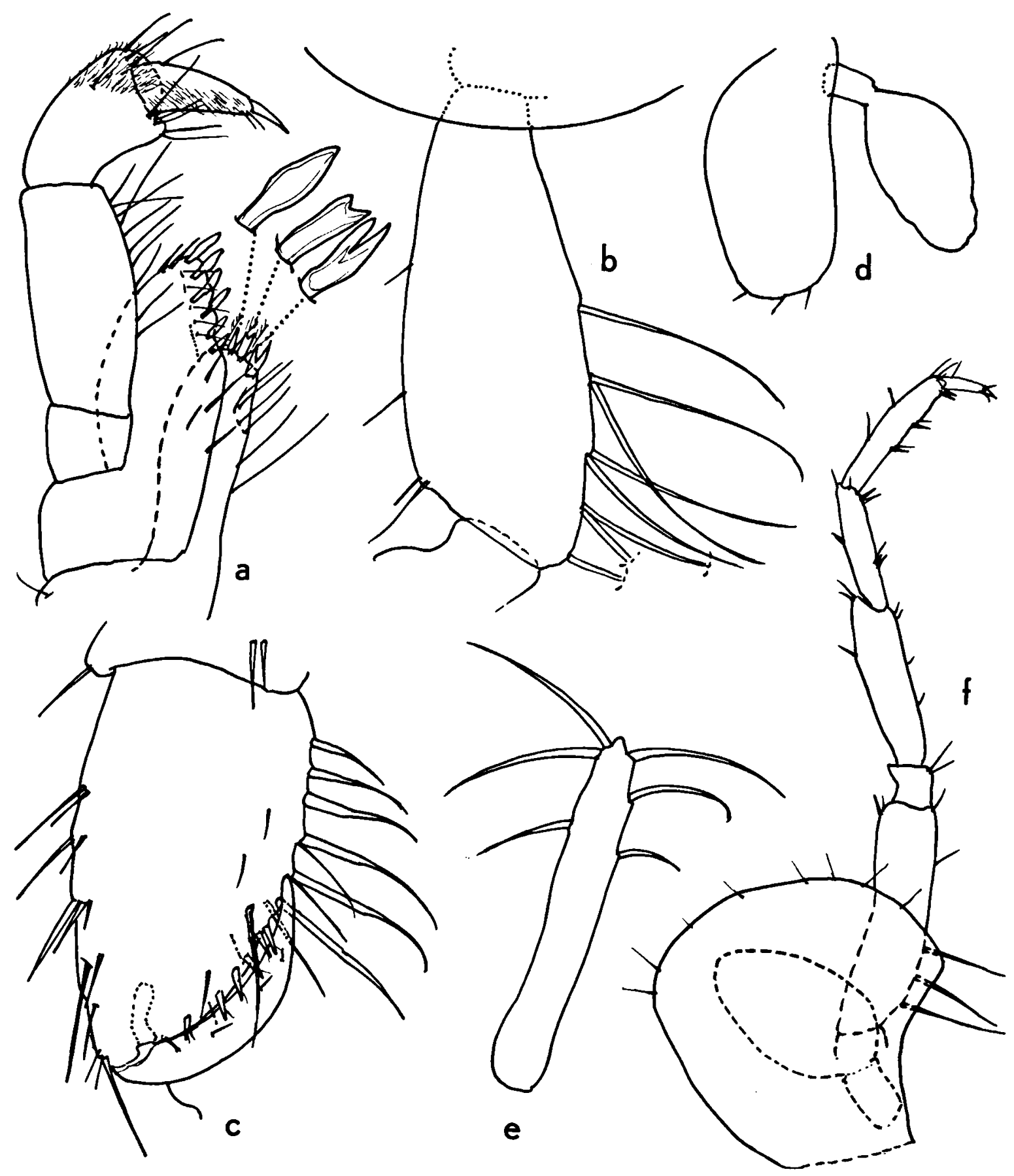

Fig. 59. Zombiweckelia parvipalpus n. gen., n. sp. (all from sta. 78-224, but for b, from sta. 79-584): a, maxilliped, $\$$ (scale 3 ); b, basis of second gnathopod, $\&$ (3); c, propodus of second gnathopod, $\&$ (3); d, coxal plate and gill of third pereiopod, $\sigma^{*}$ (2); e, oostegite of third pereiopod, $Q$ (8); f, fourth pereiopod, $\sigma$ (2). Scales on fig. 11. 


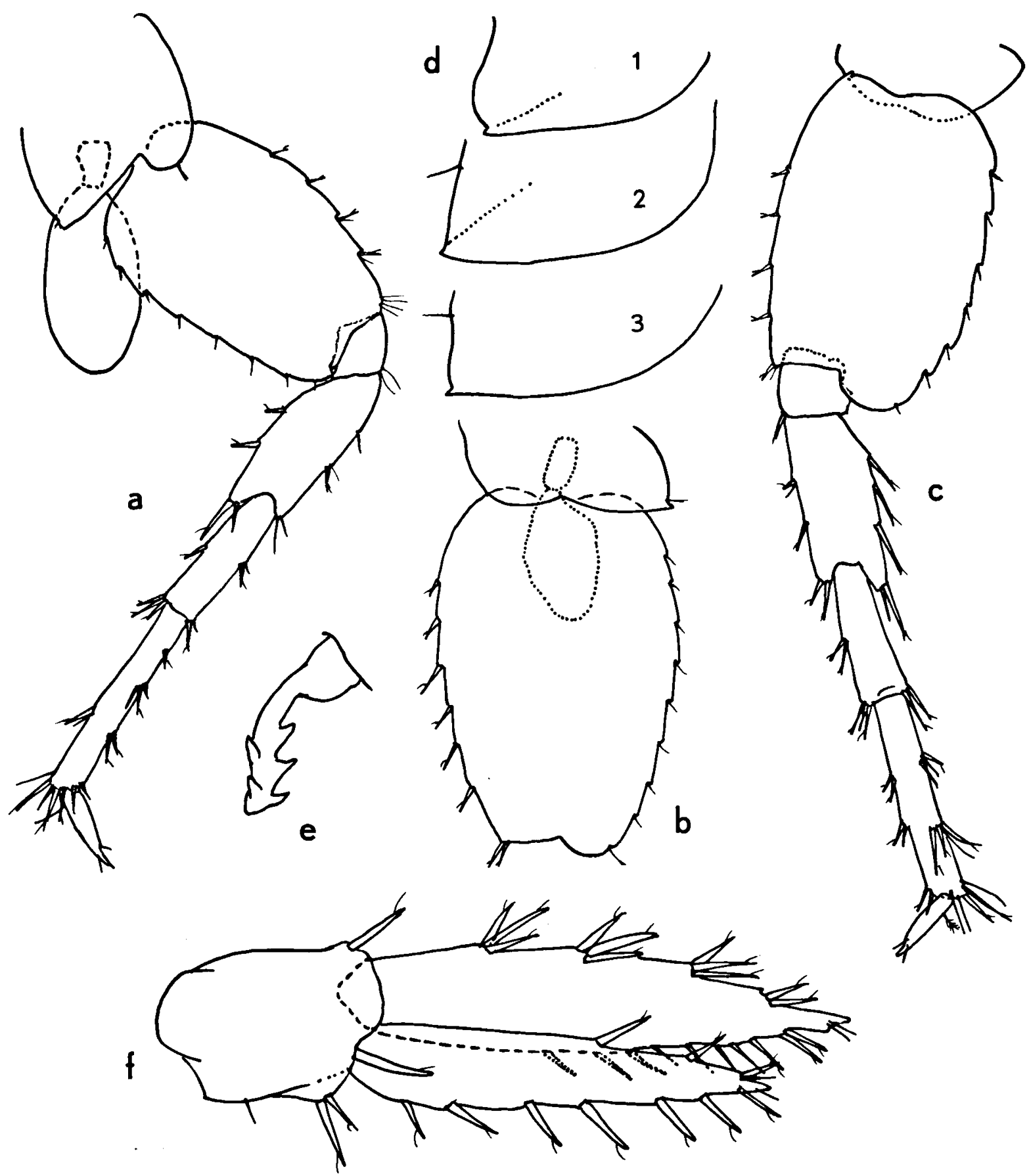

Fig. 60. Zombiweckelia parvipalpus n. gen., n. sp. (sta. 78-224): a, fifth pereiopod, $९$ (scale 2); b, basal part of sixth pereiopod, $\sigma^{\circ}(2)$; c, seventh pereiopod, $९$ (2); d, epimeral plates 1-3, $\sigma^{\circ}(2)$; e, retinaculum of third pleopod, $\sigma^{\circ} ; \mathrm{f}$, third uropod, $\$$ (3). Scales on fig. 11. 
spine and 2 long setae near the palmar angle; both spine and long setae are hair-tipped (fig. 57d).

Gnathopod 2 (fig. 58a): Basis as in gnathopod 1. Carpus triangular, not lobate. Merus without patch of spinules. Propodus sexually dimorphic: in the male (fig. 58a) it is larger than in the female (fig. 59c); the posterior margin bears, mostly unpaired, setae; the palmar margin bears about $10\left(\sigma^{\circ}\right)$ or $7(\&)$ hair-tipped spines. No palmar angle spines. Claw of the male longer than that of the female.

Coxal gills on legs 2 through 6, distinctly pedunculate (fig. 59d, f), gill blade oval. Oostegites (fig. 59e) linear, on legs 2 through 5.

Third coxal plate (fig. 59d) elongate. Pereiopod 4 (fig. 59f): Coxal plate with posterior emargination. Legs 5 to 7 not very slender. Pereiopod 5 (fig. 60a) shorter than P 6; basis with posterior lobe, not overhanging. Pereiopods 6 (fig. 60b) and 7 (fig. 60c) subequal. Basis lobate, overhanging; distal segments with long spines.

Pleopods not sexually dimorphic or modified, biramous; each ramus 8- to 10-segmented. Retinacula (fig. 60e) with 2 or 3 lateral teeth. Clothpeg spines on proximomedial margin of the pleopodal endopodite segments absent, or only a single spine present.

Epimeral plates (fig. 60d) with small posteroventral tooth; ventral margin unarmed; posterior margin of plates 2 and 3 with 1 setule, not crenulated.

Uropod 1 (fig. 58b): With proximoventral spine; rami narrow, with 2 to 4 dorsal spines. Uropod 2 (fig. 58c) as illustrated. Uropod 3 (fig. 60f): Exopodite slightly longer than endopodite, both rami 1-segmented and armed with spines only (but for a few terminal setules); peduncle not elongated.

Telson (fig. 55f): Completely cleft; each lobe twice as long as wide; sensorial setae on the lateral margin, somewhat beyond the middle, well apart; distal armature consisting of 3 or 4 spines and 1 setule; the lobes show a distal notch.

Distribution. - Found in wells and rheocrene springs in two adjacent hydrographic zones (St. Marc/Duvalierville zone and Cul-deSac zone, $L$ and $M$ on fig. 3 ) in central Haiti. Although several localities are near the sea or near the border of brackish lakes, the species seems to live in (almost) fresh waters. In stations 224, 584, and 587, Zombiweckelia was found associated with Crangoweckelia spinicauda; in station 584 also with $C$. mixta.

\section{Radaweckelia n. gen.}

Diagnosis. - Blind. First antenna: accessory flagellum well developed, 3- or 4-segmented. Mandibular palp 1-segmented, small; molar small, with seta on right side only. Lower lip without inner lobes. Palps of 1st maxilla almost symmetrical; outer lobe with 7 distal spines; inner lobe narrow, medial margin setose. Second maxilla with oblique row of setae. Maxilliped: distal spines on inner blade bicuspidate.

Gnathopod 1: carpus not elongate; propodus small, with only 1 palmar angle spine. Gnathopod 2: carpus triangular, propodus sexually dimorphic $\left(\sigma^{\circ}>\&\right.$, in the male 2 palmar angle spines plus 5 pairs of palmar margin spines, in the female 2 palmar angle spines plus 1 pair of mid-palmar spines). Oostegites linear, on P2 through P5. Coxal gills stalked, small, on P2 to P6. Coxal plate 4 hardly emarginate. Coxal plate 5 anterolobate. Basis of P5 to P7 slightly produced, not overhanging.

Uropod 1 with proximoventral spine; uropod 2 without row of peduncular spinules; rami of both U1 and U2 spinose. Uropod 3 short, inner ramus almost of parviramous-type, outer ramus 1-segmented. Telson almost completely cleft; lobes slender, with distal spines only.

Remarks. - From the Haitian genera, Zombiweckelia appears to be the most closely related to the new genus. Differences are found in uropod 3 (magniramous in $Z$., varii- to parviramous in $R$.), the mandible (molar toothed and with longer molar seta in $Z$., palp more strongly developed, 2- to 3-segmented in $Z$.), and coxal plate 4 (hardly emarginate in $R$.). 
Among the extra-Haitian genera, no doubt Weckelia, endemic to Cuba, is the closest relative. Differences are found in antenna 1 (segment 2 very narrow and elongate in $W$.), the presence of "normal" (= not bicuspidate) teeth on the inner lobe of the maxilliped in $W$., the presence of inner lobes on the labium of $W$., the greater number of spines on the palp and on the outer lobe of maxilla 1 in $W$., the longer carpus of $\mathrm{P} 1$ in $W$. , the absence of spines on the palmar margin ( $q$ ) of $\mathrm{P} 2$ in $W$., and the magniramous uropod 3 in $W$.

Type-species. - Radaweckelia brevicauda $\mathbf{n}$. sp. The genus is hitherto monospecific.

Etymology. - Combination of Weckelia (an existing generic name in hadziids) and rada (one of the Voodoo rituals on Haiti); the "rada" part alludes to the "mysteriously" diminished mandibular palp. The specific name, brevicauda, refers to the short uropod 3 .

\section{Radaweckelia brevicauda n. sp.}

(Figs. 61-67)

Material. - One ovigerous $\$$ (holotype), one $\sigma$ (allotype), and more than sixty paratypes. Amsterdam Expeditions to the West Indian Islands, sta. 79-625. Haiti: Dép. du Centre, karst springs known as Ara, near the waterfall (Saut d'Eau), hamlet La Selle, Ville Bonheur (near Mirebalais) $\left(18^{\circ} 49^{\prime} 31^{\sim} \mathrm{N} 72^{\circ} 13^{\prime} 05^{\sim} \mathrm{W}\right)$; large clear springs; alt. ca. $400 \mathrm{~m}$; chlorinity $27 \mathrm{mg} / 1$; temp. $21.0^{\circ} \mathrm{C}$; 26 Nov. 1979 (ZMA Amph. 107.815).

Eight specimens. Sta. 78-218, Dép. du Centre, small springs E. of the hamlet of Trianon ( $=\mathrm{S}$. of Mirebalais); in the bank of a brooklet; slowly running; loam and sand; estimated position $18^{\circ} 47^{\prime} 31^{\prime \prime} \mathrm{N} 72^{\circ} 06^{\prime} 41^{\prime \prime} \mathrm{W}$; chlorinity 90 $\mathrm{mg} / \mathrm{l}$; temp. not recorded; 6 May 1978 (ZMA Amph. 107.819).

Ten specimens. Sta. 78-222. Dép. du Centre, W. of Mirebalais, hamlet of Boé on the S. bank of the river Artibonite (on road $\mathrm{N} 109)\left(18^{\circ} 50^{\circ} 30^{\circ} \mathrm{N} 72^{\circ} 07^{\prime} 50^{\sim} \mathrm{W}\right.$ ); fastrunning spring in the river bank; sand, roots; chlorinity 30 mg/l; temp. not recorded; 6 May 1978 (ZMA Amph. 107.823).

One $\$$. Sta. 78-238. Dép. du Nord, well on N. side of road D100 near Limbé $\left(19^{\circ} 42^{\prime} 29^{\sim} \mathrm{N} 72^{\circ} 23^{\circ} 53^{\sim} \mathrm{W}\right)$; closed well, water level at $2 \mathrm{~m}$, water depth $1 \mathrm{~m}$; chlorinity 240 mg/l; 10 May 1978 (ZMA Amph. 107.822).

Twenty-six specimens. Sta. 79-604. Dép. de l'Artibonite, outskirts of Dessalines, karst spring, side-outlet of La Source $\left(19^{\circ} 15^{\prime} 06^{\nu} \mathrm{N} 72^{\circ} 30^{\prime} 31^{\nu} \mathrm{W}\right.$; in sand with lime- stone boulders; chlorinity $39 \mathrm{mg} / \mathrm{l}$; temp. $27.5^{\circ} \mathrm{C}$; 23 Nov. 1979 (ZMA Amph. 107.817).

Thirty-six specimens. Sta. 79-626. Dép. du Centre, large rheocrene spring known as Pin, hamlet La Selle, Ville Bonheur, at the foot of the Morne Massicot $\left(18^{\circ} 49^{\circ} 31^{\prime \prime} \mathrm{N} 72^{\circ} 12^{\prime} 55^{\prime} \mathrm{W}\right)$; stones, coarse sand and vegetation; chlorinity less than $10 \mathrm{mg} / \mathrm{l}$; temp. $21.0^{\circ} \mathrm{C} ; 27$ Nov. 1979 (ZMA Amph. 107.816).

Thirty-two specimens. Sta. 79-627. Dép. du Centre, "La Source Saut d'Eau" (not the waterfall of sta. 79-625) at the foot of the Morne Massicot, Ville Bonheur; stones, sand; chlorinity less than $10 \mathrm{mg} / \mathrm{l}$; temp. $21.0^{\circ} \mathrm{C} ; 27$ Nov. 1979 (ZMA Amph. 107.820).

Three $९$ \&, one ${ }^{\circ}$. Sta. 79-693. Dép. du Nord, well of the Communitary School at Camp Coq $\left(19^{\circ} 38^{\circ} 09^{\sim} \mathrm{N}\right.$ $72^{\circ} 25^{\prime} 13^{\sim} \mathrm{W}$ ); covered, clean well, with sandy bottom; alt. ca. $80 \mathrm{~m}$; water level at $4.5 \mathrm{~m}$, water depth $0.4 \mathrm{~m}$; chlorinity $13 \mathrm{mg} / \mathrm{l}$; temp. $26.6^{\circ} \mathrm{C}$; $11 \mathrm{Dec} 1979$ (ZMA Amph. 107.821).

One $\sigma^{\circ}$. Sta. 79-694. Dép. du Nord, well of the Presbytère (= Rectory) at Camp Coq, some $200 \mathrm{~m}$ from sta. 79-693; water level at $3.4 \mathrm{~m}$, water depth $1.1 \mathrm{~m}$; chlorinity $13 \mathrm{mg} / \mathrm{l}$; temp. $26.2^{\circ} \mathrm{C}$; $11 \mathrm{Dec} 1979$ (ZMA Amph. 107.818).

Description. - Body length of male $3 \mathrm{~mm}$, of ovigerous females slightly more than $3 \mathrm{~mm}$. Blind, unpigmented. Urosomite 1 with 1 or 2 dorsal setules, urosomite 2 with 1 pair of setules and 1 pair of spines, urosomite 3 without spines (fig. 61g).

All specimens more or less damaged. The following morphological observations are based on several dissected specimens.

Antenna 1 (fig. 61a) about half as long as the body. Length of the peduncle segments (in ovigerous female) 409, 250, and $163 \mu \mathrm{m}$, respectively. Accessory flagellum rather long, 234 $\mu \mathrm{m}, 4$-segmented (fig. 61c) or 3-segmented (fig. $61 \mathrm{~b})$. Flagellum long, up to 16 -segmented, segments 9 to 15 with an aesthetask, which is $60-66 \%$ of the length of the corresponding segment.

Antenna 2 shorter than antenna 1 (fig. 61d). Gland cone heavy. Peduncle segments 4 and 5 not very slender. Flagellum short, 9-segmented.

Upper lip of the usual shape (fig. 61e). Lower lip without inner lobe, medial cleft narrow (fig. $61 \mathrm{f})$.

Mandible with short, 1-segmented palp (fig. 62a). The molar is small; molar flake well 


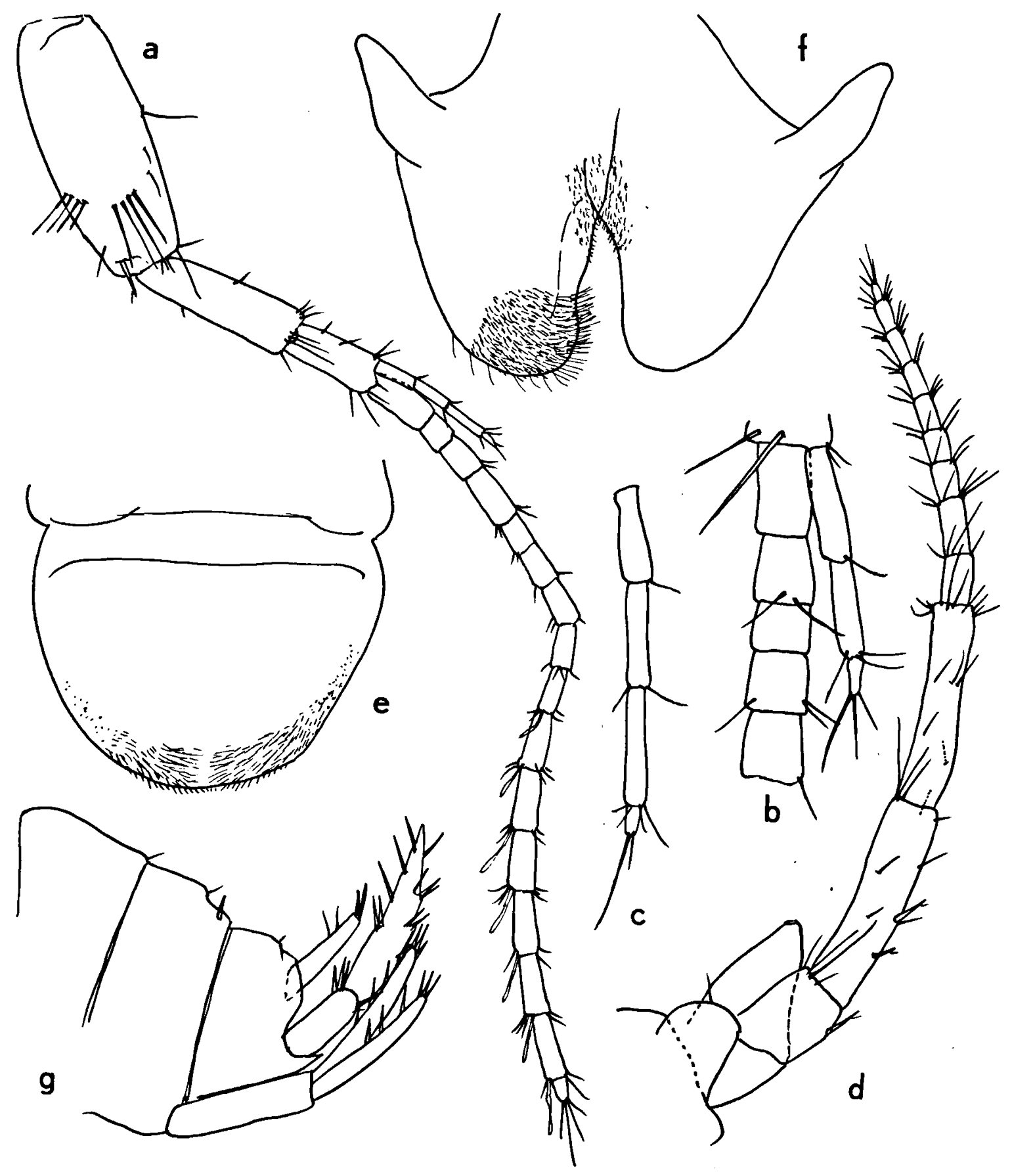

Fig. 61. Radaweckelia brevicauda n. gen., n. sp. ( $९$, sta. 79-625): a, first antenna (scale 2); b, c, accessory flagella of two different $\$$ ९ (2); d, second antenna (2); e, upper lip (3); f, lower lip (3); g, urosome, from the left (2). Scales on fig. 11. 

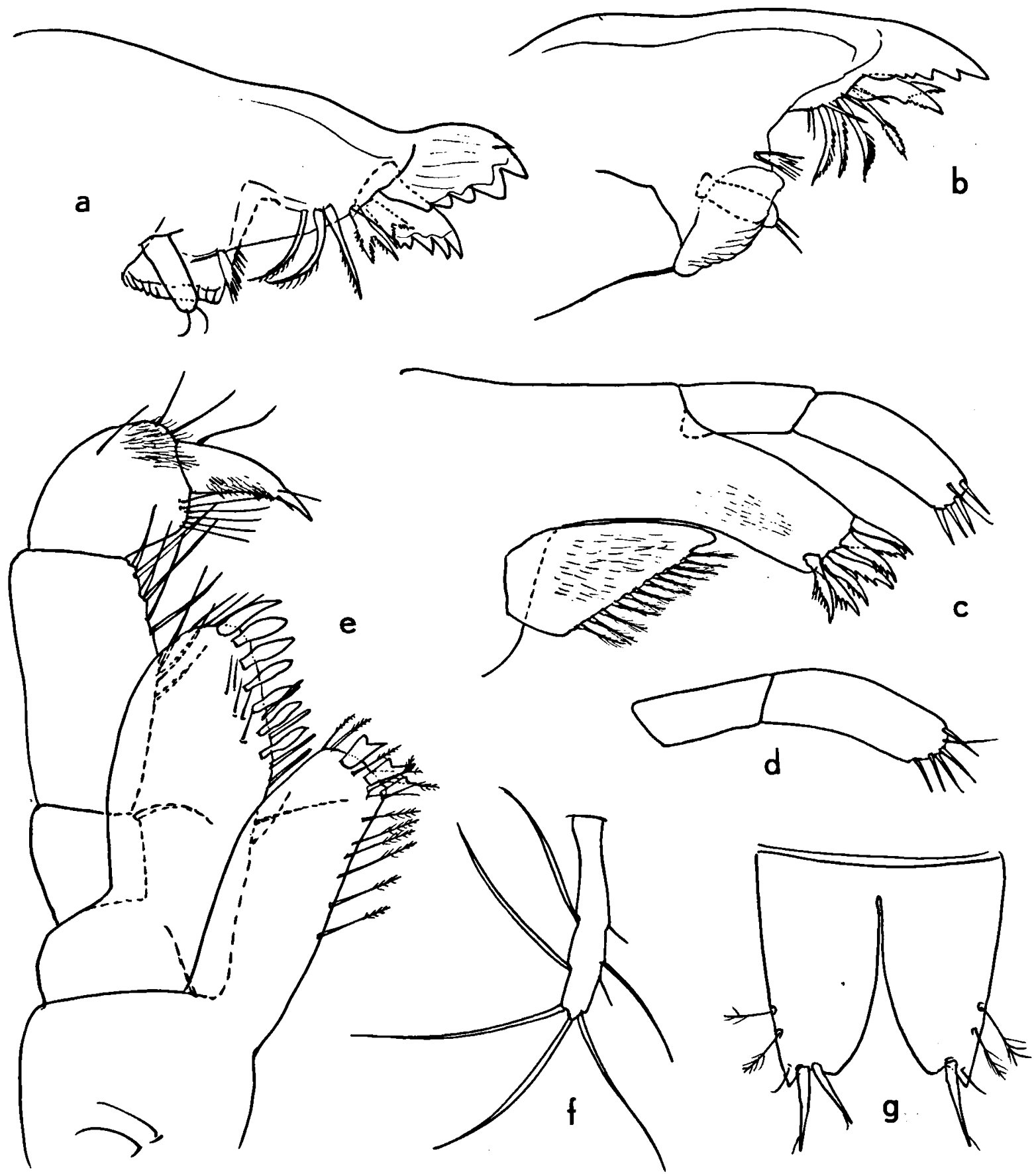

Fig. 62. Radaweckelia brevicauda n. gen., n. sp. ( 9 , sta. 79-625): a, left mandible (scale 3); b, right mandible (3); c, left first maxilla (3); d, palp of right first maxilla (3); e, maxilliped (3); f, oostegite of gnathopod 2 (2); g, telson (3). Scales on fig. 11. 
developed; right molar with rather short seta. Lacinia mobilis with 4 coarse teeth (left), or bifid, finely toothed (right). Pars incisiva (left) very heavy. Between the lacinia and the molar there are 4 barbed elements and several minute setules (right), or 2 bifid elements plus 3 barbed setae (left) (figs. 62a, b).

Maxilla 1 (fig. 62c) with narrow, triangular inner plate, armed on its medial margin with some 12 plumose setae. Outer plate with 7 distal spines, the medial margin of which bears, from medial to lateral, $2,3,3,3,3,4$, and 6 denticles, respectively. Palp segment 2 about 1.5 times as long as segment 1 (left, right); palp segment 2 (right) hardly wider than that on the left side; distal armature consisting of 4 spines +1 seta (left) or 5 spines +1 seta (right); the left and right spines are equally slender (figs. 62c, d).

Maxilla 2 as in Zombiweckelia. The diagonal row on the inner plate consists of up to 22 plumose setae.

Maxilliped (fig. 62e): Inner plate not much shorter than outer one, distally armed with 3 bicuspidate ("molar-shaped") spines.

Gnathopod 1 (fig. 63a): Merus densely covered with spinules. Carpus short, triangular, hardly lobate. Propodus roughly rectangular. Only 1 hair-tipped angle spine ( $Q$, ơ); palmar margin armed with a few setae (fig. $63 \mathrm{~b})$.

Gnathopod 2 (fig. 64a): Carpus triangular, non-lobate. Propodus ovate, in the male (fig. 64c) larger than in the female (fig. 64a). Palma oblique; palmar angle not well marked; tip of claw opposing 3 long setae, no spines; palmar margin with 2 pairs ( $Q$, fig. $64 \mathrm{~b}$ ) or 5 pairs $(\sigma)$ of strong spines.

Coxal gills (figs. 64a, 65a) on P2 through P6; stalk robust, with distinct distal articulation. No sternal gills. Oostegites (fig. 62f) linear, on P2 through P5. Eggs few, 1 to 3 per female.

The entire posterior margin of coxal plates 3 (fig. 65a) and 4 (fig. 63c) is slightly concave, but plate 4 has no true emargination.

Pereiopod 5 (fig. 65b): basis slightly tapering, with small posterodistal lobe; coxal plate anterolobate. Distal segments lacking in all specimens examined.

Pereiopod 6 (fig. 65c): Basis slightly longer than in $\mathrm{P} 5$; coxal plate equilobate. Distal segments spiniferous, not very slender. Claw long.

Pereiopod 7 (fig. 66a-c): Basis non-lobate, coxal plate non-lobate. Distal segments lacking in most specimens available, slightly more elongate than in P6.

Epimeral plates (fig. 63d) with a minute point.

Pleopods: Both rami 9-segmented. Pleopod 3 $\left(\sigma^{\circ}\right)$ without lobes, similar to that of the $Q$; medial margin of the endopodite with 1 clothpeg spine. Retinacula slender, with 3 pairs of marginal teeth (fig. 67a).

Uropod 1 (fig. 66d): Peduncle with proximoventral spine. Exopodite slightly shorter than endopodite; both rami with dorsal spines.

Uropod 2 (fig. 65d): Peduncle without distal row of spinules. Both rami spinose.

Uropod 3 (fig. 65e) short. Exopodite 1-segmented, pointed, both margins spinose. Endopodite small, less than $1 / 3$ of the length of the exopodite, truncate at the tip, with terminal spines only.

Telson (fig. 62g): Almost completely cleft. Lobes not shortened, with 1 or 2 distal spines only. Sensorial setae implanted near the lateral margin.

Variability. - Some smaller specimens: accessory flagellum 3-segmented. Basis of P5 through P7 with fewer spinules on posterior border; long segments of P5 through P7 with longer spines. Mandibular palp 1-segmented, as in adults, but slightly more slender. Telson with 1 distal spine.

In particular, the variability in the number of segments of the accessory flagellum is noteworthy: a similar variation appears to exist in Weckelia (see Holsinger, 1977).

Specimens from the dép. du Nord (stations 79-693, 78-238) are very similar to those from the dép. du Centre, except for having a slightly longer inner ramus of uropod 3 , which is some- 


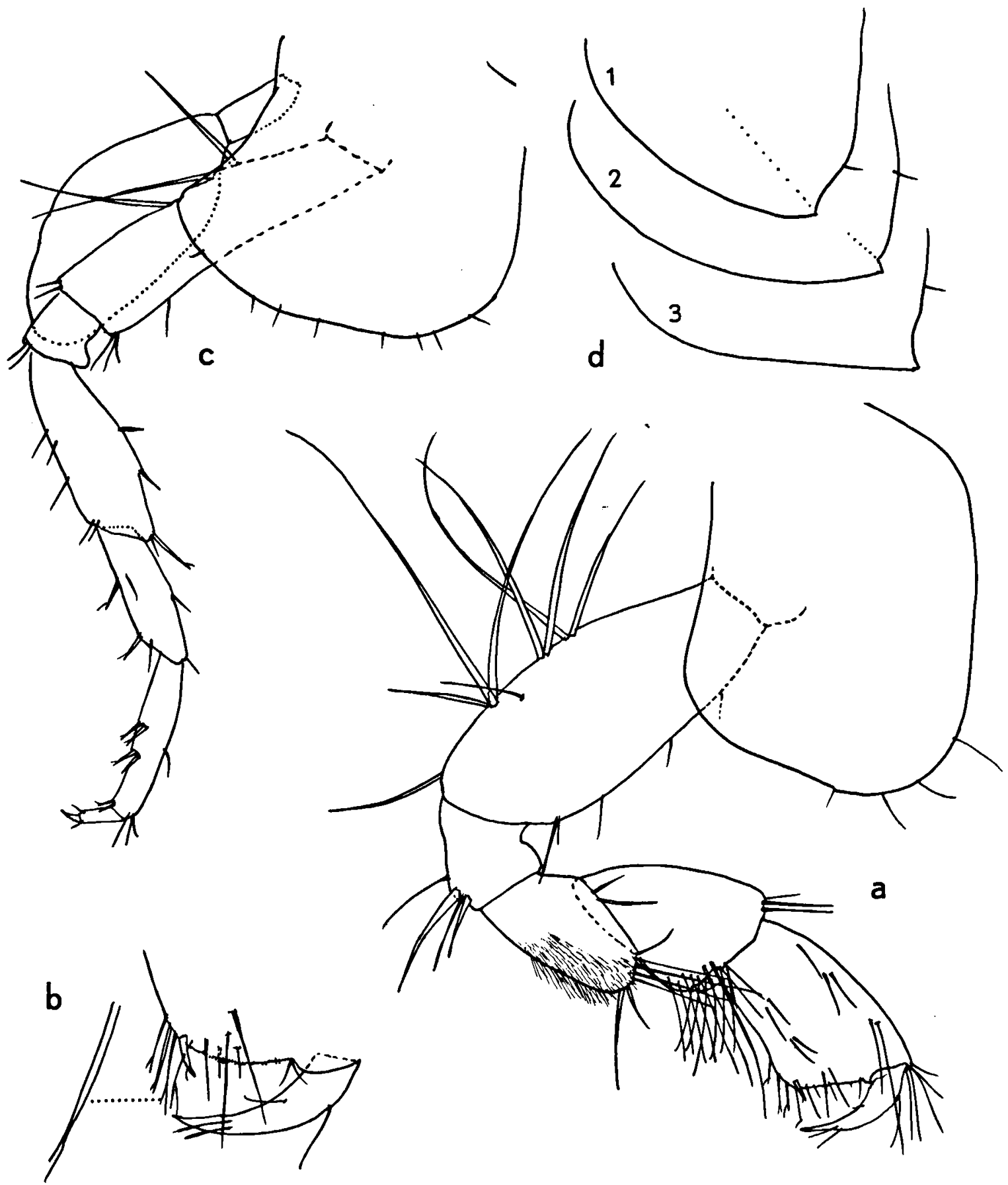

Fig. 63. Radaweckelia brevicauda n. gen., n. sp. ( 9 , sta. 79-625): a, first gnathopod (scale 8); b, palma of first gnathopod (9); c, fourth pereiopod (2); d, epimeral plates 1-3 (8). Scales on fig. 11. 


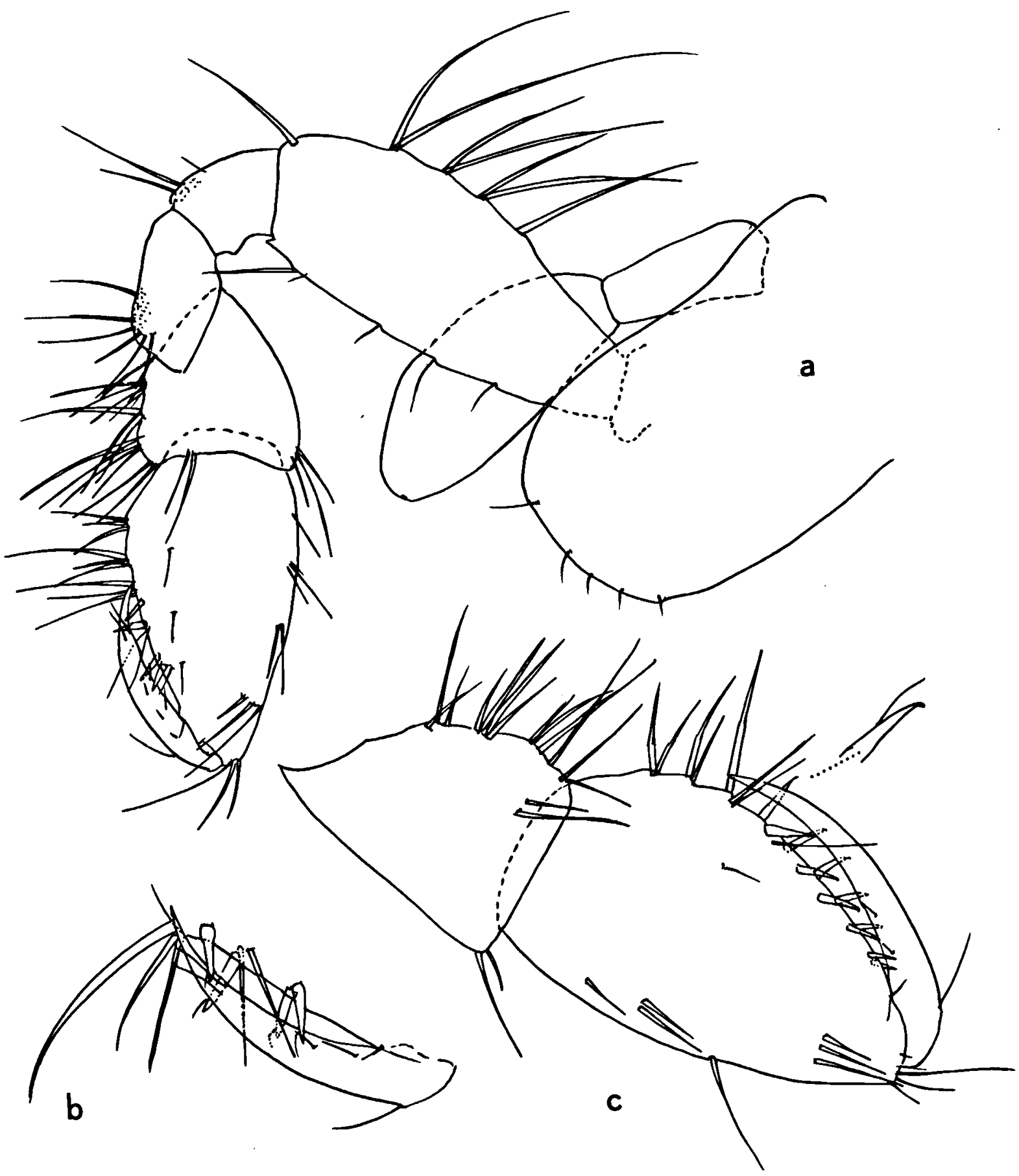

Fig. 64. Radaweckelia brevicauda n. gen., n. sp. (sta. 79-625): a, second gnathopod, $\$$ (scale 8); b, palma of second gnathopod, $\$$ (9); c, distal segments of second gnathopod, $\sigma^{\prime}(3)$. Scales on fig. 11. 

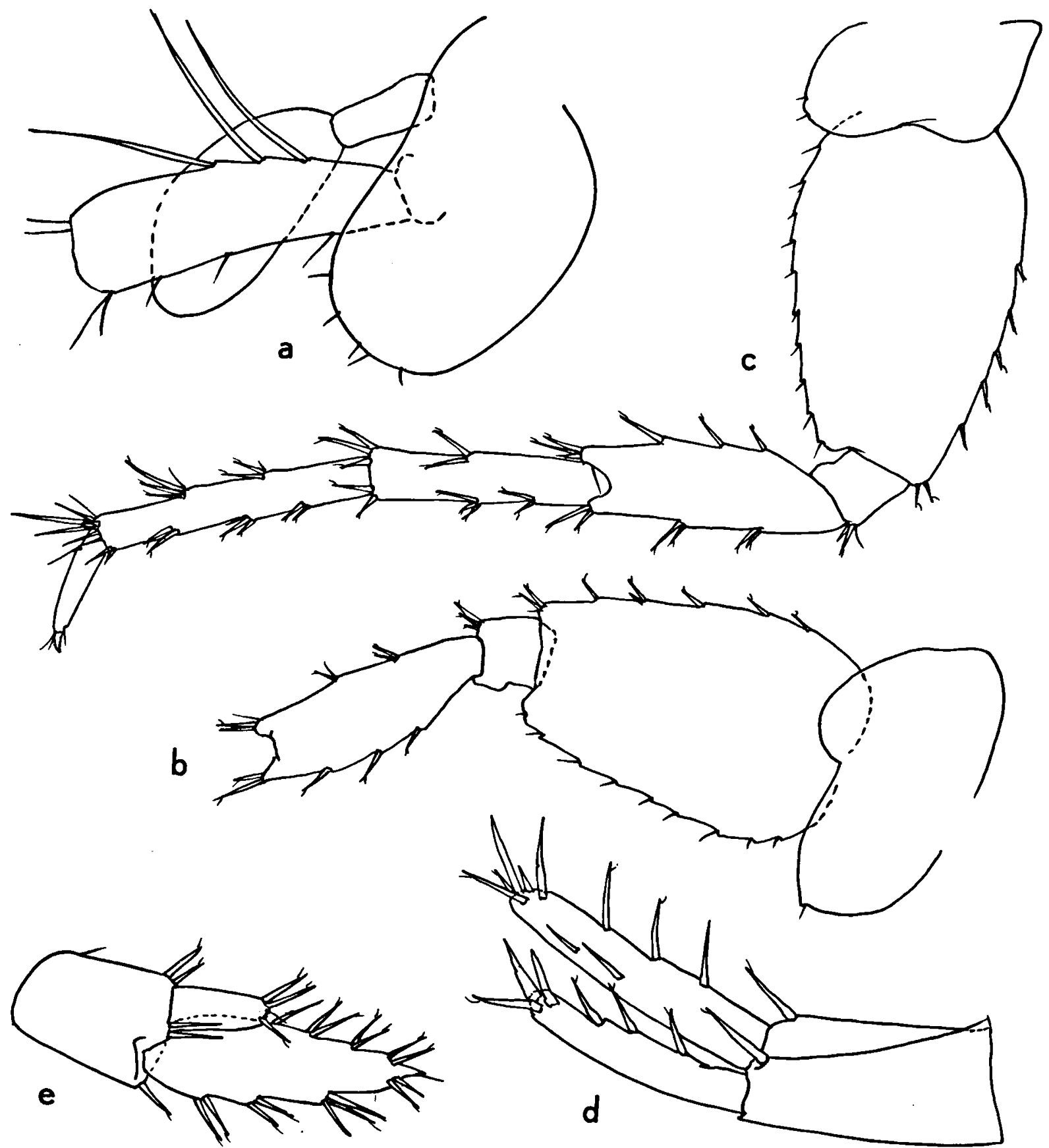

Fig. 65. Radaweckelia brevicauda n. gen., n. sp. ( $Q$, sta. 79-625): a, basal part of third pereiopod (scale 2); b, basal part of fifth pereiopod (2); c, sixth pereiopod (2); d, second uropod (8); e, third uropod (3). Scales on fig. 11. 


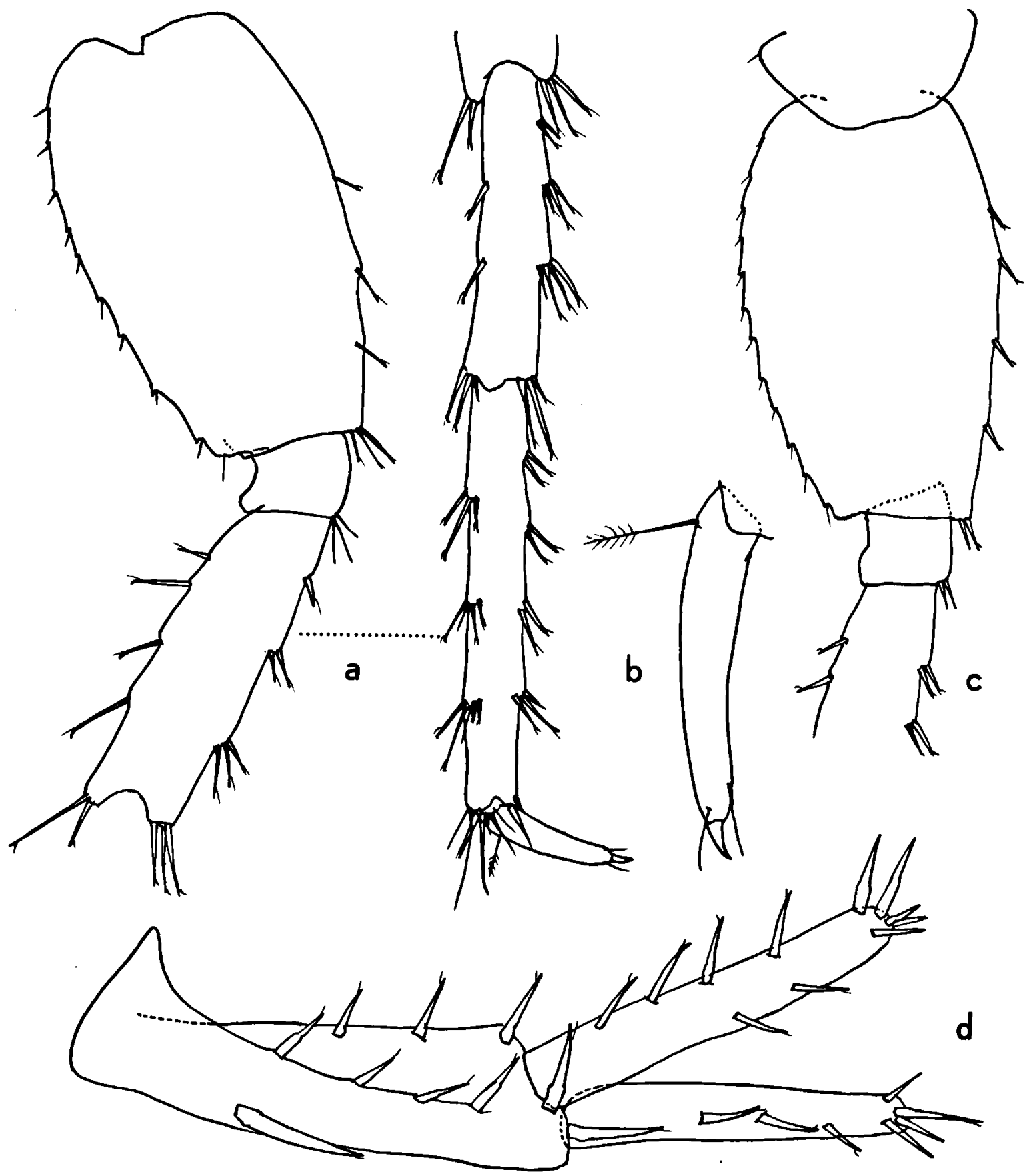

Fig. 66. Radaweckelia brevicauda n. gen., n. sp. ( $Q$, sta. 79-625, but for a \& b, from sta. 79-693): a, seventh pereiopod (scale 2); b, claw of seventh pereiopod (2); c, basal part of seventh pereiopod (2); d, first uropod (8). Scales on fig. 11. 


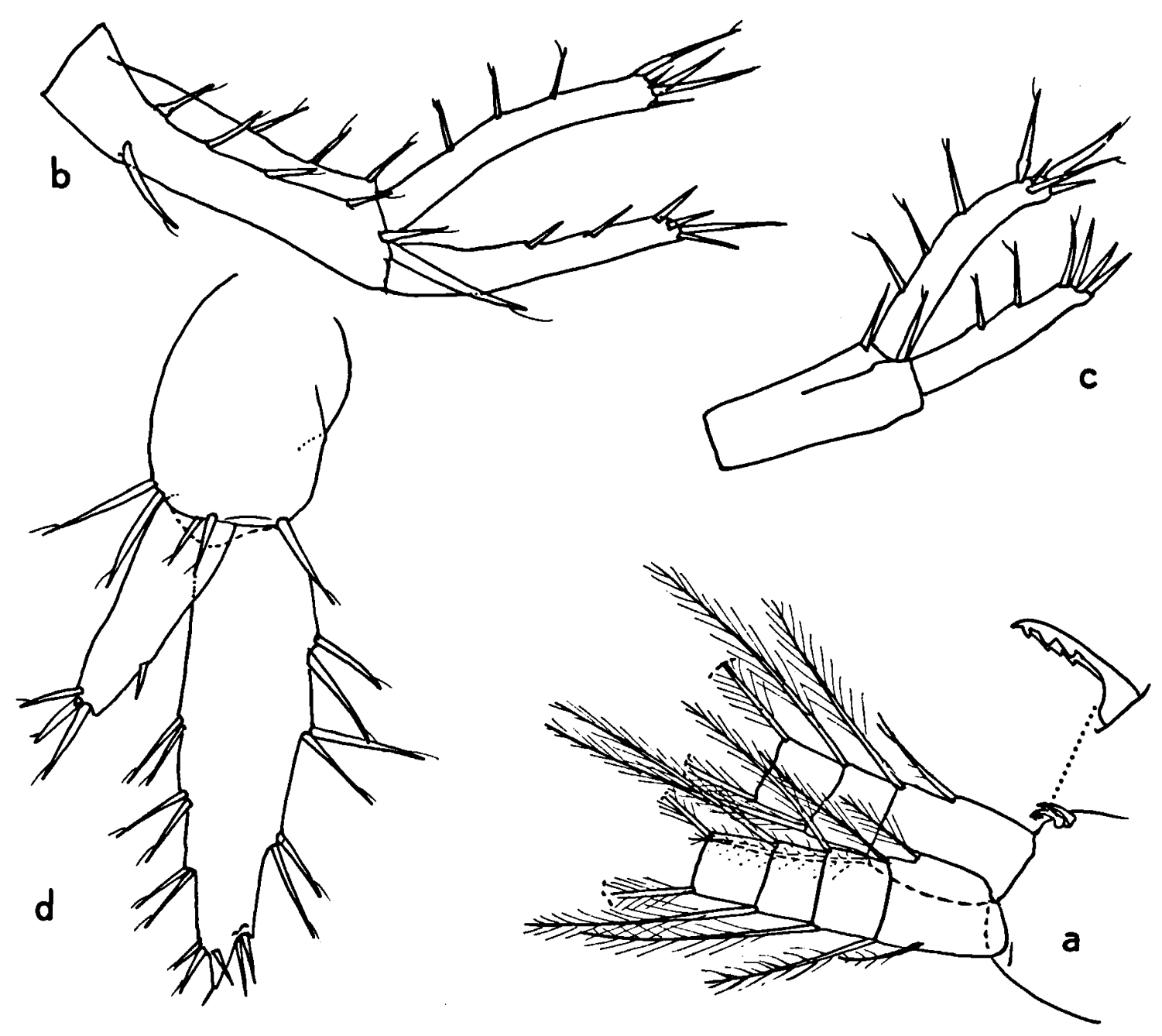

Fig. 67. Radaweckelia brevicauda n. gen., n. sp. (all from sta. 79-693, but for a, from sta. 79-625): a, third pleopod, o (scale 3); b, first uropod, 9 (8); c, second uropod, $\$$ (8); d, third uropod, $\$$ (8). Scales on fig. 11.

times (but not always) provided with a pair of spines on its lateral margin (fig. 67d).

In several samples (79-693, 78-238, 79-694) uropods 1 (fig. 67b) and 2 (fig. 67c) look feebly sclerotized; the rami tend to curve and the spines are longer than in the type series. For the moment I do not attach taxonomic value to these variations, pending the discovery of more samples from the dép. du Nord and from intermediate localities between Limbé (Nord) and Mirebalais (Centre).

Distribution. - The species is known from 3 different hydrographic basins in the northern half of Haiti, the basins of Limbé, of l'Estère and of l'Artibonite (F, J, and $\mathrm{K}$, respectively, in figs. 2 and 3 ).

\section{Apoweckelia n. gen.}

Diagnosis. - Blind. Antenna 1: accessory flagellum reduced to 1-segmented vestige. Mandible without palp; right molar with plumose seta, left molar without one. Lower lip with inner lobes. Maxilla 1: inner lobe fingershaped, armed with 2 distal setae only. Maxilla 2 without oblique row of setae. Outer lobe of 
maxilliped with several triangular teeth on inner margin. Gnathopod 1: palmar margin armed with setae only. Gnathopod 2: carpus not elongate, propodus ovate; palmar margin armed with spines in both sexes. Coxal plate 4 emarginate. Pereiopods 5 and 6 anterolobate; coxal plate 7 non-lobate. Basis of P5 through P7 slightly lobate. Pleopod $3\left(\sigma^{\circ}\right)$ without strong lobes. Uropod 3 parviramous; outer ramus unimerous. Telson completely cleft, with distal armature only.

Remarks. - There are 8 weckelioids/hadzioids that are devoid of a mandibular palp, viz. Weckelia, Mexiweckelia, Mayaweckelia, Texiweckelia, Allotexiweckelia, Paramexiweckelia, I Iexi. weckeliopsis, and Holsingerius. These have all magniramous third uropods, (many) more setae on the inner lobe of the first maxilla, and an untoothed outer lobe of the maxilliped. In these respects, the new genus stands out clearly from the related taxa.

Type-species. - Apoweckelia serrata n. sp. The genus is so far monospecific.

Etymology. - A number of apomorphic characters of the new genus have inspired the generic name Apoweckelia (rudimentary accessory flagellum, absence of mandibular palp, reduced armature of inner lobe of maxilla 1 , modified outer lobe of maxilliped, parviramous uropod 3). The specific name, serrata, alludes to the serrated margin of the outer lobe of the maxilliped.

Apoweckelia serrata $n$. sp.

(Figs. 68-73)

Material. - One or (holotype), one ovigerous \& (allotype), 16 paratypes. Amsterdam Expeditions to the West Indian Islands, sta. 79-524. Haiti: Dép. du Sud, spring Dubreuil II at Ducis, some $500 \mathrm{~m}$ downstream of a small dam on the Acul river $\left(18^{\circ} 14^{\prime} 44^{\prime \prime} \mathrm{N} 73^{\circ} 53^{\prime} 58^{\prime \prime} \mathrm{W}\right)$; gravel, sand; chlorinity not determined (fresh water); temp. $22.5^{\circ} \mathrm{C}$; 6 Nov. 1979 (ZMA Amph. 107.842).

Twenty-nine specimens. Sta. 79-523. Spring Dubreuil I, near previous station, in stones and gravel amongst the roots of an old Ficus tree; chlorinity $24 \mathrm{mg} / \mathrm{l}$; other data as above (ZMA Amph. 107.843).
Description. - Blind, unpigmented (fig. $68 \mathrm{a})$. Body length $\left(\sigma^{\circ}\right.$, $\left.\%\right)$ 2.2-3.2 mm. Urosomite 1 with a pair of dorsal setules, urosomite 2 with a pair of dorsal spines, urosomite 3 unarmed (fig. 72c). Head without antennal sinus (fig. 68e).

Antenna 1 (fig. 68b) about $3 / 4$ of the length of the body. Peduncle segment 1 with 2 ventral spines and several setae, length $307 \mu \mathrm{m}$; segment 2 armed with some setae, length $317 \mu \mathrm{m}$; segment 3 narrow, elongate, length $204 \mu \mathrm{m}$ (measurements based on ovigerous female). Flagellum 24-segmented; segments 15 through 21 with a short aesthetask (shorter than half the length of the corresponding segment). Accessory flagellum (fig. 68c) reduced to a $1-\mathrm{seg}$ mented bud-like vestige, armed with 4 or 5 short setae.

Antenna 2 (fig. 68d) distinctly less than half as long as antenna 1 . Gland cone slightly downcurved; peduncle segments 3 and 4 each with 2 dorsal spines. Flagellum 10-segmented. No calceoli.

Upper lip (fig. 69a) with regularly rounded free margin. Lower lip (fig. 69d) with distinct, though not very large, inner lobes.

Mandibles without palp. Pars molaris with a short row of posterior teeth; medial margin smooth. The right molar always bears a strong, plumose seta; the left one sometimes lacks such a seta. Pars incisiva strong, toothed. Lacinia mobilis (right) bifid, bearing a row of 5 small teeth plus a row of cilia (fig. 69b); left lacinia with 3 stronger teeth in front of the terminal prong (fig. 69c). Between the lacinia and the molar, there are 3 (right) or 4 (left) strong, feather-like elements.

Maxilla 1 (fig. 71a): Palp 2-segmented; article 1 unarmed; article 2 with 5 spines +1 seta. Right and left palps similar. The outer lobe bears 9 terminal spines, the medial margin of which is armed with teeth, from lateral to medial $2,2,1,1,3,2,2,3$, and 4 teeth, respectively. The inner lobe is unusual; it is digitiform; its medial margin is unarmed, except for some minute cilia; distally, the lobe bears only 2 short, plumose setae.

The two lobes of maxilla 2 (fig. 69e) are nar- 


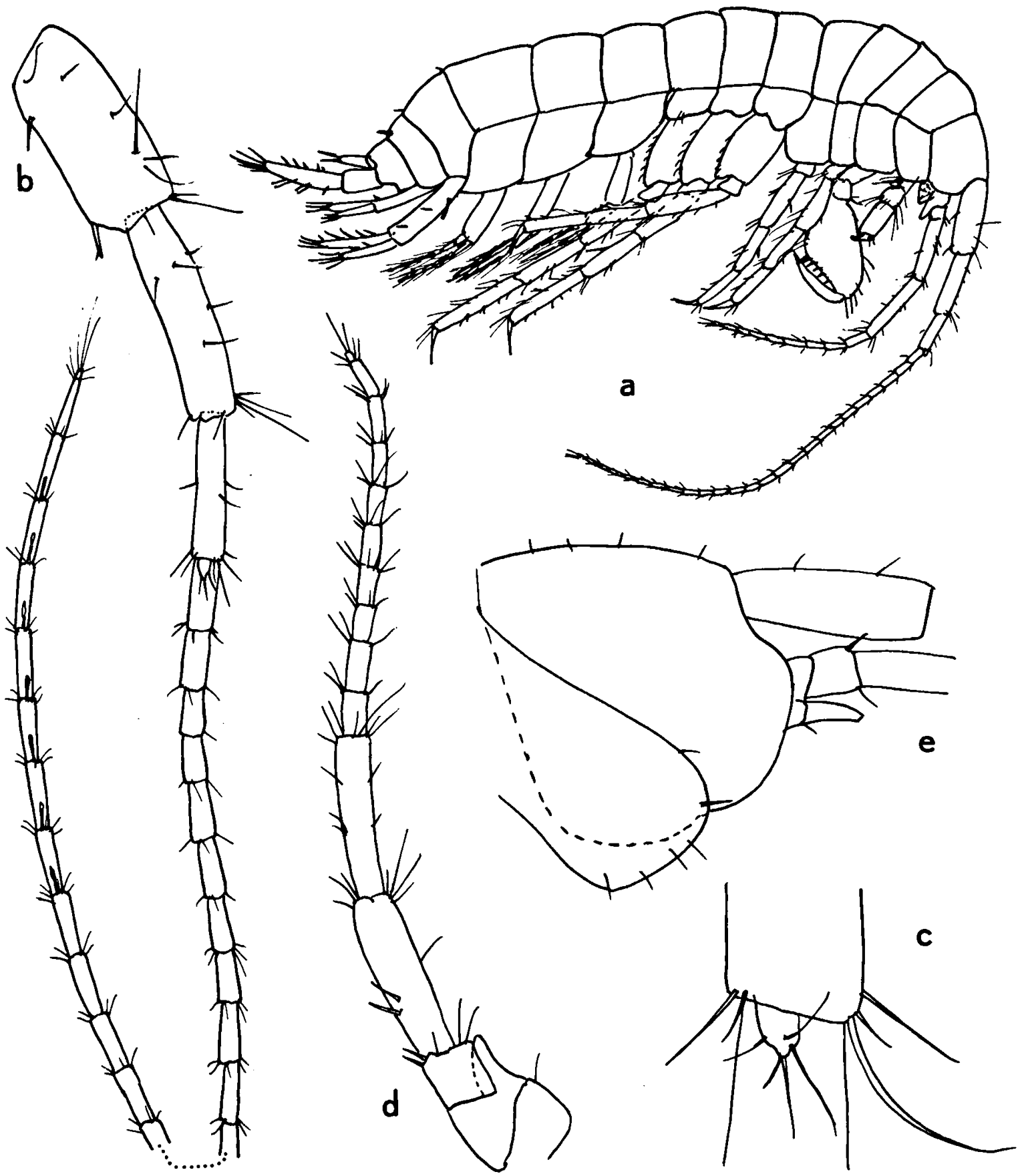

Fig. 68. Apoweckelia serrata n. gen., n. sp. (sta. 79-524): a, holotype, $\sigma^{\circ}$, from the right (actual size $3 \mathrm{~mm}$ ); b, first antenna, $\uparrow$ (scale 2); c, accessory flagellum, ९ (4); d, second antenna, ९ (2); e, cephalic segment, $९$, from the right (2). Scales on fig. 11. 


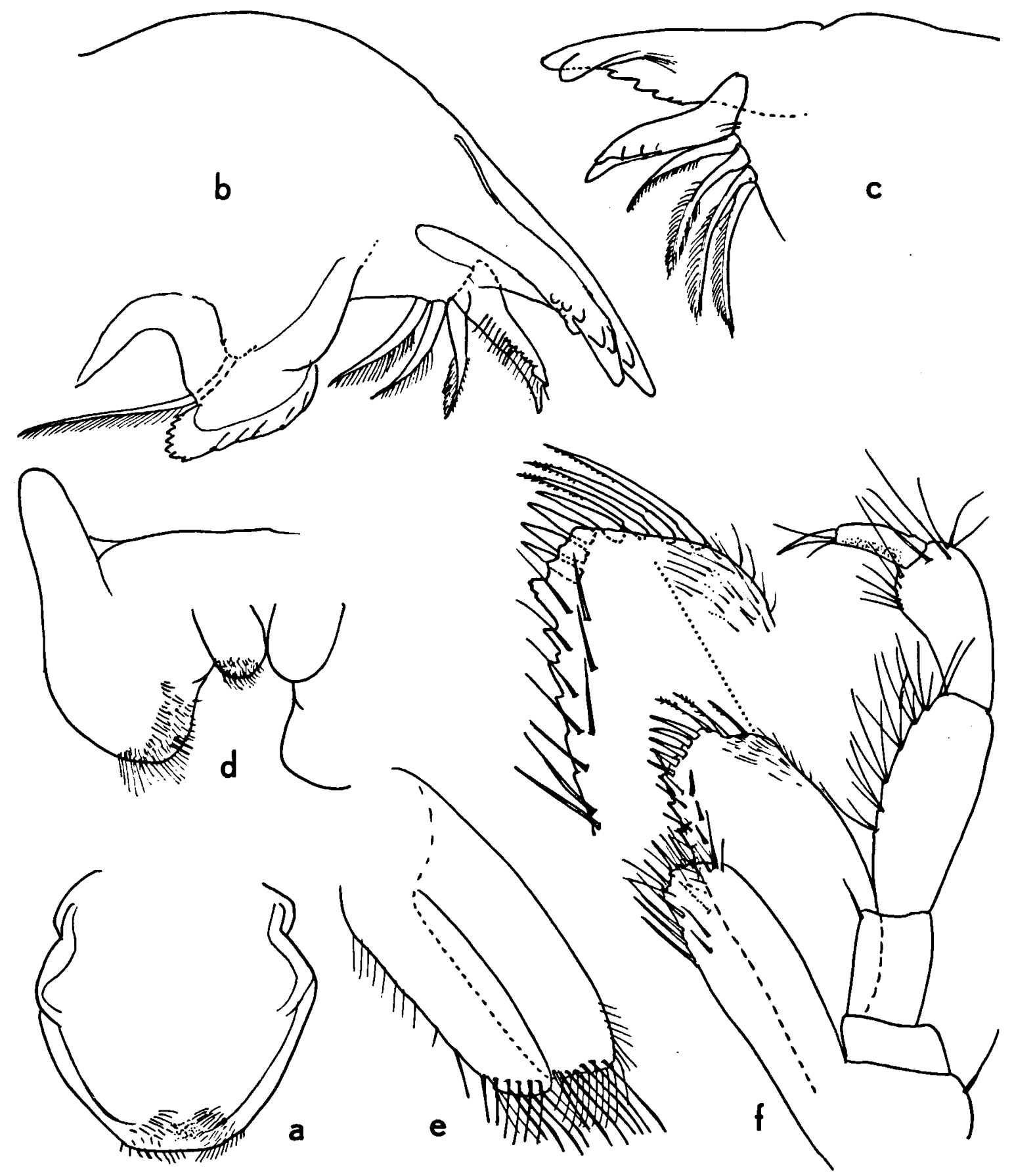

Fig. 69. Apoweckelia serrata n. gen., n. sp. (sta. 79-524): a, upper lip, $\sigma^{\circ}$ (scale 8); b, right mandible, $\&$ (4); c, pars incisiva of left mandible, $९$ (4); d, lower lip, $९$ (9); e, second maxilla, $९$ (3); f, maxilliped, $९$ (3). Scales on fig. 11. 


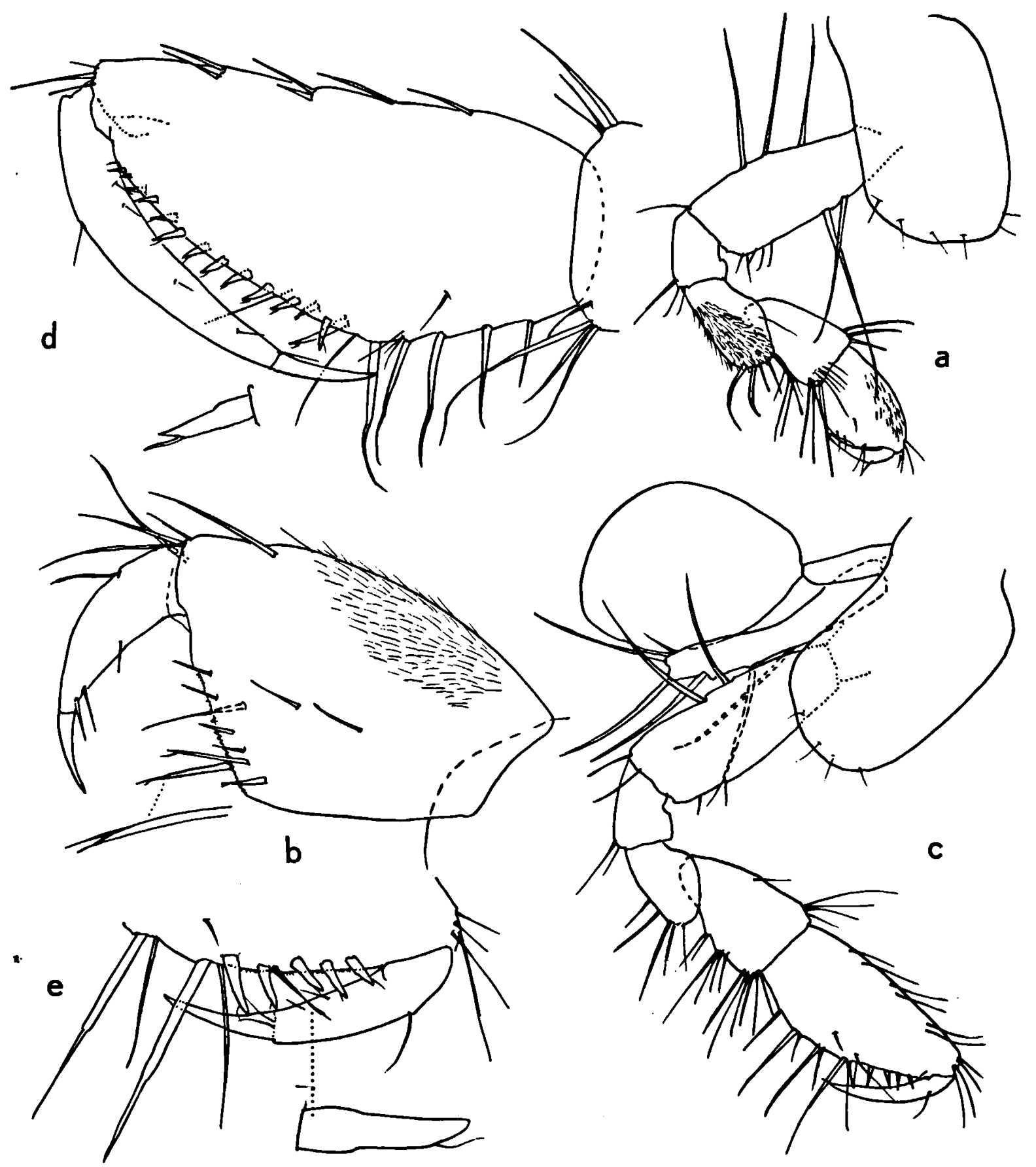

Fig. 70. Apoweckelia serrata n. gen., n. sp. (sta. 79-524): a, first gnathopod, $\$$ (scale 2); b, propodus of second gnathopod, $\sigma^{\circ}$ (3); c, second gnathopod, $९$ (2); d, propodus of second gnathopod, O* (4); e, palma of second gnathopod, $९$ (3). Scales on fig. 11. 


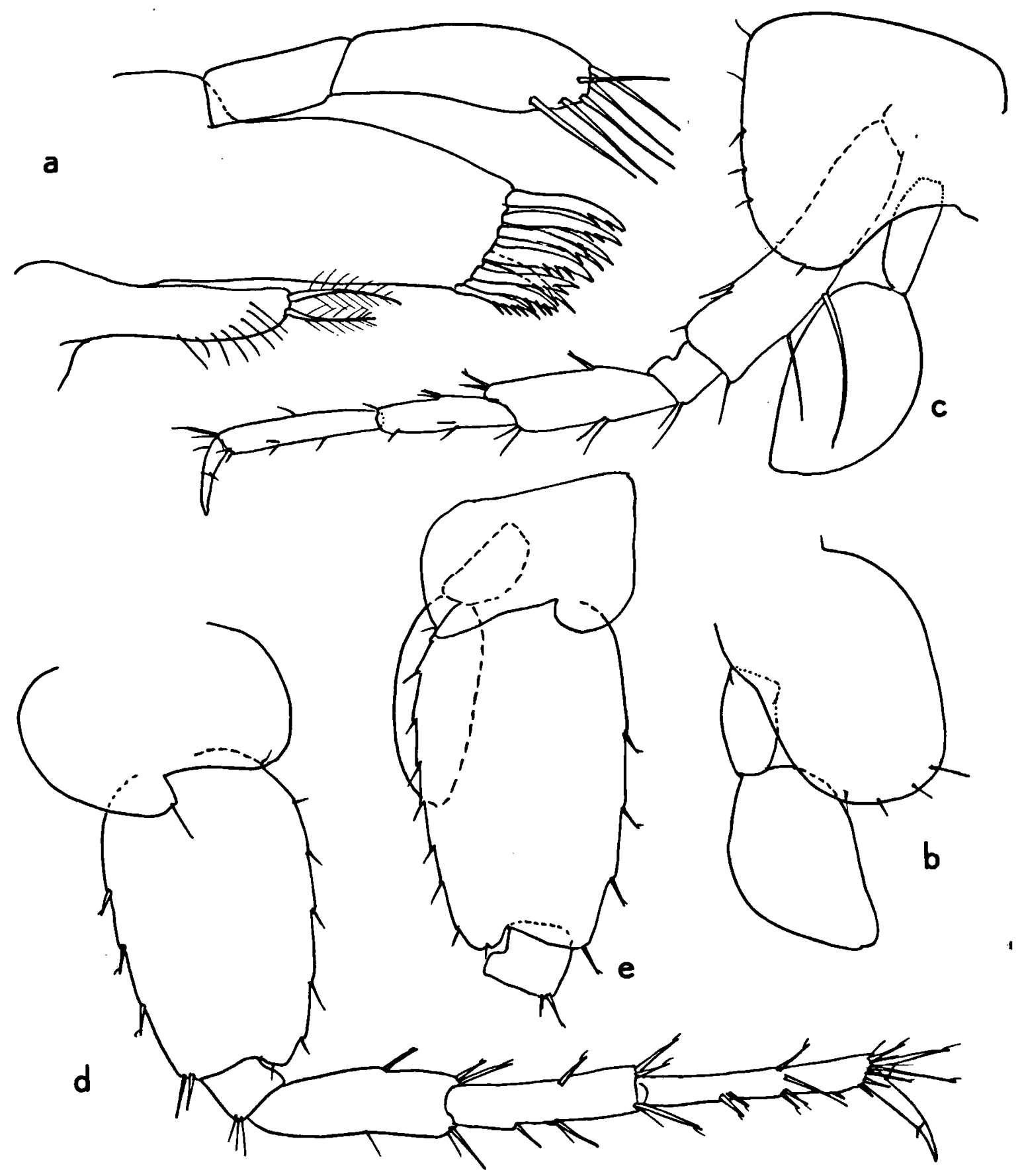

Fig. 71. Apoweckelia serrata n. gen., n. sp. (Q, sta. 79-524): a, first maxilla (scale 4); b, third coxal plate and gill (2); c, fourth pereiopod (2); d, fifth pereiopod (2); e, basal part of sixth pereiopod (2). Scales on fig. 11. 
row; the outer lobe bears distally 2 rows of setae, 7 to 10 setae per row; the inner lobe bears distally likewise 2 rows of setae, 5 to 7 setae per row; the medial margin of the inner lobe bears 3 setae in its distalmost part and some fine cilia in its basal part; no oblique row of setae.

The maxilliped (fig. 69f) has a 4-segmented palp; segment 4 is slightly lobate. The distal claw is slender, but not exaggeratedly. The outer lobe bears 3 setae and 4 spines at its distal margin; its medial margin bears 4 pairs of small spines, but is mainly characterized by the presence of 4 triangular teeth, or serrations, in the distal third of the segment (fig. 69f, detail). Inner lobe narrow, spiniferous.

Oostegites on legs 2 through 5 , linear, setose in their distal half (fig. 70c). Coxal gills on legs 2 through 6 ; stalk very distinct, separated by a constriction from the gill blade; the latter is broadly elliptical (P2, fig. 70c), to pear-shaped (P3 through P5, figs. 71b, c), or sausage-shaped (P6, fig. 71e).

Coxal plates 1, 2, and 3 longer than wide, inferior margin rounded; coxal plate 4 (fig. $71 \mathrm{c}$ ) about as long as wide, with a posterior emargination.

Gnathopod 1 (fig. 70a) not sexually dimorphic. The basis bears long setae, 3 on the posterior and 2 on the anterior margin. Merus hirsute. Carpus not modified (neither elongate, nor lobate). The propodus (fig. 70b) may be called mitten-shaped; it widens from its insertion towards the palmar angle. The palmar angle is armed with 3 setae; the palmar margin is minutely serrate and bears 4 short setae; (bifid) spines lack entirely on the palma.

Gnathopod 2 (fig. 70c) with 2 long setae on the posterior margin of the basis, and 2 very short ones on the anterior margin. Carpus "normal", i.e. trapezoidal and non-lobate. Propodus sexually dimorphic. In the female (fig. 70c, e) the palmar margin and the claw are shorter than in the male (fig. 70d). The absolute size of the male propodus is also larger. The palmar angle is marked by 2 setae; the palmar margin bears $5(\%)$ or $14\left(O^{\prime}\right)$ spines, slightly decreasing in length and tipped with a setule (fig. 70d, detail). Outer margin of the claw with 1 short seta.

Pereiopod 3 (but for the coxal plate) similar to pereiopod 4 (fig. 71c); posterior margin of the basis with 2 long setae, anterior margin with 1 or 2 spines. Ungulus longer than in other Haitian species.

Pereiopod 5 (fig. 71d) shorter than P 6 . Posterior margin of the basis with some 6 widely spaced setules; posterodistal corner armed with a minute setule, lobate, slightly overhanging. Distal segments armed with (long) spines.

Pereiopod 6 (fig. 71e): Posterior margin of basis with some 8 setules.

Pereiopod 7 (fig. 72a) resembling P6, but somewhat longer.

Epimeral plates (fig. 72b) unarmed, without oblique stripe; posteroventral corner produced into a small triangular process.

Pleopods biramous, rami multi-articulate. Two retinacula per pleopod, each with 3 pairs of hooks (fig. 73a). One clothpeg spine on pleopods 1 and 2, none on pleopod 3. The basal two segments of the endopodite of pleopod $3\left(0^{\circ}\right)$ are fused and show a hardly noticeable lateral swelling (fig. 73a). The two proximal setae on the medial margin of the endopodite are reduced in length, as is the most proximal seta on the medial margin of the exopodite. This reduction in length is also found in the same setae of pleopods 1 and 2 .

Uropod 1 (fig. 73b) has a proximoventral spine. Both rami bear 2 or 3 dorsal spines and 4 (long) distal spines.

In uropod 2, the exopodite is slightly shorter than the endopodite (fig. 73c).

Uropod 3 has 1-segmented rami (fig. 72d). The endopodite is scale-like, armed with 1 terminal spine; the exopodite has 2 groups of spines, both on its lateral and its medial margins; the truncate distal margin bears 9 long spines.

The telson (fig. 72e) is completely cleft. The lobes have almost straight lateral and medial margins, without armature. The distal margin bears a triangular process and a notch; there 


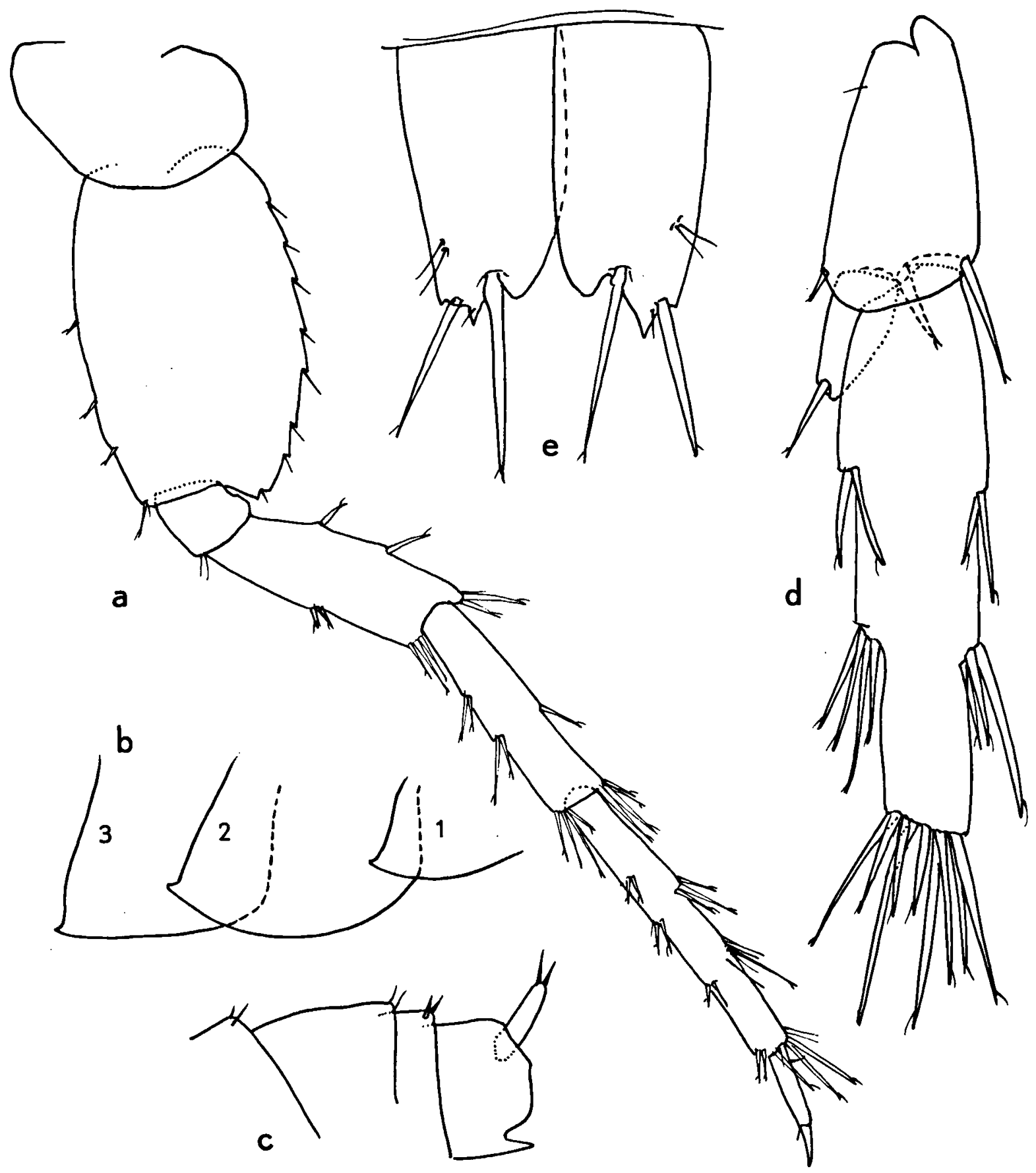

Fig. 72. Apoweckelia serrata n. gen., n. sp. (sta. 79-524): a, seventh pereiopod, $९$ (scale 2); b, epimeral plates 1-3, $९$ (2); c, urosome, $\sigma$, from the left (2); d, third uropod, $\odot$ (3); e, telson, $\sigma^{*}(4)$. Scales on fig. 11. 


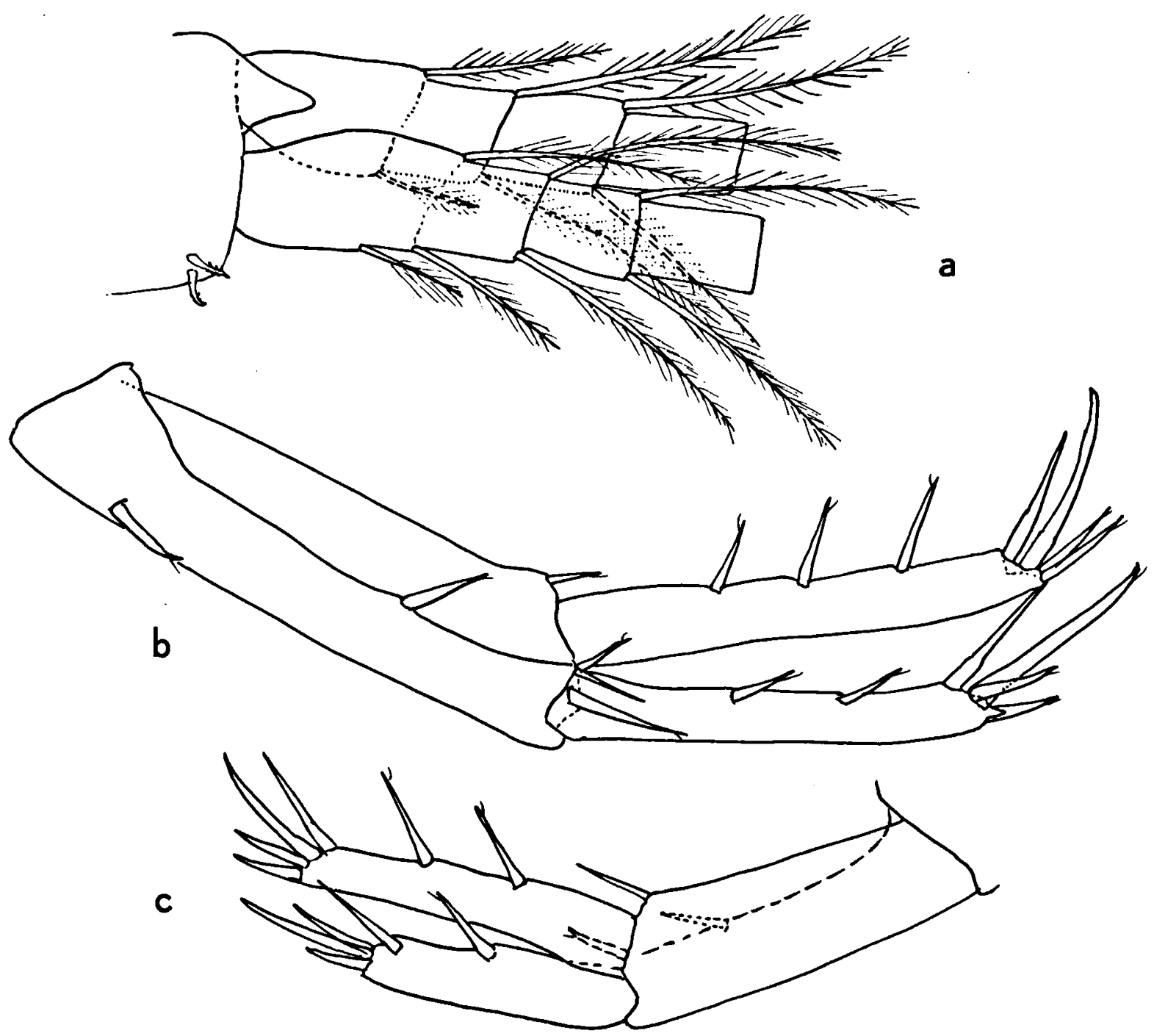

Fig. 73. Apoweckelia serrata n. gen., n. sp. ( $\sigma^{\circ}$, sta. 79-524): a, basal part of third pleopod (scale 4); b, first uropod (3); c second uropod (3). Scales on fig. 11.

are 2 long distal spines. The two sensorial setae are short, apparently not plumose, and placed not far from the distal end.

Remarks. - This small species from a spring complex cannot be confused with any other Haitian or Caribbean species. It resembles more closely certain taxa from Central and North America, with a vestigial accessory flagellum and a lacking mandibular palp.

Distribution. - The species is only known from two closeby springs in the Cayes hydrographic zone in the west of Haiti's southern peninsula (zone $X$ in fig. 4).

\section{UNIDENTIFYABLE HADZIOIDS/WECKELIOIDS}

Juvenile or damaged, isolated specimens of what appear to be hadzioid or weckelioid amphipods, have been obtained by the Amsterdam Expeditions to the West Indian Islands in the following Haitian stations:

Sta. 79-510. One juv. Metaniphargus sp. Dép. du Sud, Cayes area, Puits Cambuy, at several hun- 
dreds of metres from the house of Regillisse $\left(18^{\circ} 15^{\prime} 10^{\prime} \mathrm{N} 73^{\circ} 47^{\prime} 10^{\circ} \mathrm{W}\right)$; open well, water level at $3 \mathrm{~m}$, water depth $8 \mathrm{~m}$; chlorinity 12 $\mathrm{mg} / \mathrm{l}$; temp. $28.8^{\circ} \mathrm{C}$; 1 Nov. 1979.

Sta. 79-517. One damaged specimen. Dép. du Sud, La Grande Ravine du Sud, ca. $7 \mathrm{~km}$ from the mouth of the river $\left(18^{\circ} 13^{\prime} 29^{\mu} \mathrm{N}\right.$ $73^{\circ} 46^{\prime} 53^{\sim} \mathrm{W}$ ); interstices of coarse sand and gravel; chlorinity $116 \mathrm{mg} / \mathrm{l}$; temp. $27.7^{\circ} \mathrm{C} ; 4$ Nov. 1979.

Sta. 79-521. One damaged juvenile. Dép. du Sud, large captured karstic spring called Desgrottes, at Thorbeck $\left(18^{\circ} 09^{\prime} 24^{\prime \prime} \mathrm{N} \quad 73^{\circ} 48^{\prime} 49^{\prime} \mathrm{W}\right)$; chlorinity $14 \mathrm{mg} / \mathrm{l}$; temp. $27.0^{\circ} \mathrm{C}$; 6 Nov. 1979.

Sta. 79-536. One damaged specimen (? Apoweckelia). Dép. de l'Ouest, well of Thérèse Celamy at Groureau, Cazeau, Croix-des-Missions $\left(18^{\circ} 35^{\circ} 03^{\sim} \mathrm{N} 72^{\circ} 16^{\prime} 23^{\sim} \mathrm{W}\right)$; open well dug in alluvia; water level at $3 \mathrm{~m}$, water depth 2.75 $\mathrm{m}$; chlorinity $18 \mathrm{mg} / \mathrm{l}$; temp. $28.3^{\circ} \mathrm{C} ; 10$ Nov. 1979.

Sta. 79-583. Four damaged specimens (? Zombiweckelia). Dép. de l'Ouest, well near Evangelic Church of Debas $\left(18^{\circ} 38^{\prime} 51^{\sim} \mathrm{N} 72^{\circ} 06^{\prime} 34^{\mu} \mathrm{W}\right)$; water level at $4.4 \mathrm{~m}$, water depth $1.4 \mathrm{~m}$; chlorinity $46 \mathrm{mg} / \mathrm{l}$; temp. $27.5^{\circ} \mathrm{C}$; 21 Nov. 1979.

Sta. 79-612. One damaged specimen. Dép. de l'Artibonite, Gonaïves, well of Marie Vierge Estereling, on the road Gonaïves-Cap Haitien, ca. $1.5 \mathrm{~km}$ from the sea; water level at $1.2 \mathrm{~m}$, water depth $0.5 \mathrm{~m}$; chlorinity 195 $\mathrm{mg} / \mathrm{l}$; temp. $25.9^{\circ} \mathrm{C}$; 24 Nov. 1979.

\section{REFERENCES}

Barnard, J. L. \& C. M. Barnard, 1983. Freshwater Amphipoda of the world, 1, 2: i-vii, 1-830 (Hayfield Associates, Mt. Vernon, Va.).

Bousfield, E. L., 1977. A new look at the systematics of gammaroidean amphipods of the world. Crustaceana, Suppl. 4: 282-316.

-, 1983 . An updated phyletic classification and palaeohistory of the Amphipoda. In: F. R. Schramm ed., Crustacean phylogeny. Crustacean Issues, 1: 257-277 (Balkema, Rotterdam).

Holsinger, J. R., 1975. A new cavernicolous amphipod crustacean of the genus Hadzia (Gammaridae) from Jamaica, with notes on the distribution and taxonomic status of the genus. Annls. Spéléol., "1974" 29 (4): 647-655.
,-- 1977 . Some observations on the taxonomy of the Cuban subterranean amphipod genus Weckelia (Gammaridae). Résult. Expéd. cubano-roum. Cuba, 2: 267-269 (Editura Acad. R. S. R., București).

- , 1985. In: J. R. Holsinger \& J. YAger, A new genus and two new species of subterranean amphipod crustaceans (Hadziidae) from the Bahamas and Turks and Caicos Islands. Bijdr. Dierk., 55 (2): 283-294.

Holsinger, J. R. \& S. B. Peck, 1968. A new genus and species of subterranean amphipod (Gammaridae) from Puerto Rico, with notes on its ecology, evolution and relationship to other Caribbean amphipods. Crustaceana, 15 (3): 249-262.

Shoemaker, C. R., 1942. Notes on some American freshwater amphipod crustaceans and descriptions of a new genus and two new species. Smithson. misc. Collns., 101 (9): 1-31.

-, 1959. Three new cave amphipods from the West Indies. J. Wash. Acad. Sci., 49 (8): 273-283.

Stephensen, K., 1933. Fresh- and brackish-water Amphipoda from Bonaire, Curaçao and Aruba. Zool. Jb., (Syst.) 64: 415-436.

Stock, J. H., 1977a. The taxonomy and zoogeography of the hadziid Amphipoda, with emphasis on the West Indian taxa. Stud. Fauna Curaçao, 55 (177): 1-130.

-, $1977 \mathrm{~b}$. The zoogeography of the crustacean suborder Ingolfiellidea, with descriptions of new West Indian taxa. Stud. Fauna Curaçao, 55 (178): 131-146.

-_, 1980. Un Metaniphargus (Amphipoda) nouveau de l'île Marie-Galante (Antilles). Bull. Mus. natn. Hist. nat. Paris, (4) (A, Zool.) 2 (2): 413-419.

-, 1981 . The taxonomy and zoogeography of the family Bogidiellidae (Crustacea, Amphipoda), with emphasis on the West Indian taxa. Bijdr. Dierk., 51 (2): 345-374.

-, 1983 . The stygobiont Amphipoda of Jamaica. Bijdr. Dierk., 53 (2): 267-286.

-, 1985. Bogidiellidae (Amphipoda) from Haiti and some general rules on the occurrence of Crustacea Malacostraca in inland groundwaters of the West Indies. Stygologia, 1 (2): 208-223, erratum sheet.

Stock, J. H. \& L. Botosaneanu, 1983. Première découverte d'Amphipodes Gammaridae du groupement des Hadziides dans des eaux souterraines de l'Amérique du Sud: description de Metaniphargus venezolanus sp. n. Bijdr. Dierk., 53 (1): 158-164.

Stock, J. H. * J.J. Vermeulen, 1985. Crustacées Amphipodes de la Guadeloupe en relation avec l'histoire géologique de l'île. Mém. Biospéol., “1984" 11. 